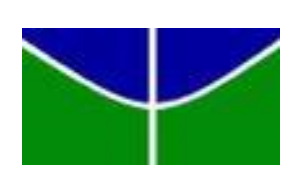

Universidade de Brasília - UnB

Faculdade de Economia, Administração, Contabilidade e Gestão de Políticas Públicas - FACE

Departamento de Economia - ECO

Programa de Pós-Graduação em Economia - PPGE

Mestrado Profissional em Economia e Gestão do Setor Público

TRANSFERÊNCIAS VOLUNTÁRIAS DO GOVERNO FEDERAL:

Uma análise sobre a ótica de planejamento, gestão e controle

Paulo Roberto Magalhães Cordeiro

Brasília

2016 
Professor Doutor Ivan Marques de Toledo Camargo

Reitor da Universidade de Brasília

Professora Doutora Sônia Nair Báo Vice-Reitora da Universidade de Brasília

Professor Doutor Mauro Luiz Rabel

Decano de Ensino de Graduação

Professor Doutor Jaime Martins de Santana

Decano de Pesquisa e Pós-Graduação

Professor Doutor Roberto de Goes Ellery Junior

Diretor da Faculdade de Economia, Administração, Contabilidade e Gestão de Políticas Públicas

Professora Doutora Adriana Moreira Amado

Chefe do Departamento de Economia 
TRANSFERÊNCIAS VOLUNTÁRIAS DO GOVERNO FEDERAL: Uma análise sobre a ótica de planejamento, gestão e controle

Dissertação de Mestrado apresentada ao Programa de Pós-Graduação em Economia da Faculdade de Economia, Administração, Contabilidade e Gestão de Políticas Públicas da Universidade de Brasília como requisito parcial para obtenção do título de Mestre em Economia e Gestão do Setor Público.

Orientadora: Prof. Dr. José Marilson Martins Dantas.

Brasília 


$$
\text { Universidade de Brasília - UnB }
$$

Faculdade de Economia, Administração, Contabilidade e Gestão de Políticas

$$
\text { Públicas - FACE }
$$

Departamento de Economia - ECO

Programa de Pós-Graduação em Economia - PPGE

Mestrado Profissional em Economia e Gestão do Setor Público

PAULO ROBERTO MAGALHÃES CORDEIRO

\section{TRANSFERÊNCIAS VOLUNTÁRIAS DO GOVERNO FEDERAL: \\ Uma análise sobre a ótica de planejamento, gestão e controle}

Dissertação de Mestrado apresentada ao Programa de Pós-Graduação em Economia da Faculdade de Economia, Administração, Contabilidade e Gestão de Políticas Públicas da Universidade de Brasília como requisito parcial para obtenção do título de Mestre em Economia e Gestão do Setor Público.

Orientador: Prof. Dr. José Marilson Martins Dantas

Banca Examinadora:

Prof. Dr. José Marilson Martins Dantas - Orientador

ECO/FACE/UnB

Profa. Dra. Magda de Lima Lucio - Membro

ECO/FACE/UnB

Prof. Dr. Eduardo Tadeu Vieira - Membro

CCA/FACE/UnB

Prof. Dr. José Antônio de França - Suplente

CCA/FACE/UnB

Brasília, de setembro de 2016 . 
Às minhas filhas, Nathália e Geovana, motivação para me aperfeiçoar constantemente. À minha mãe, Iraci, pelo exemplo de dedicação à família e por ter servido como primeira orientadora educacional, demonstrando o valor do estudo. Ao meu pai, Agacir, pela referência na busca por uma situação de melhoria de vida. À Marília, minha esposa, pela cumplicidade e paciência.

Aos meus irmãos: Algaciane, Adriana, Jorge e Vanessa, e sobrinhos, pela convivência e apoio incondicional. 


\section{AGRADECIMENTOS}

À Universidade de Brasília (UnB), à Faculdade de Economia, Administração, Contabilidade e Gestão de Políticas Públicas (FACE) e à Coordenação do Programa de Pós-Graduação em Economia (PPGE), pela oportunidade de realizar um desejo manifesto, desde os anos de graduação, de ingressar, participar e concluir uma pósgraduação scricto sensu nesta renomada instituição de ensino.

Ao Professor Doutor José Marilson Martins Dantas. O apoio, a disponibilidade, a compreensão, a dedicação e a paciência vindos de seus ensinamentos se mostraram essenciais para o desenvolvimento das linhas que se seguem.

Aos meus colegas do curso de Mestrado, em especial, aos meus amigos (ordem alfabética) Edson Rodrigues, Marcilene, Roseane Aquino, Rodrigo Arantes e Vital Macário, pela relativização nos momentos de tensão e de amplitude nas alegrias.

Aos meus colegas de trabalho, pela compreensão e apoio durante a minha jornada compartilhada entre as atividades laborais e do Mestrado.

A todos que direta ou indiretamente contribuíram para a realização do presente estudo, o meu profundo agradecimento. 
"Nenhum caminho é tão desafiador quanto dar o primeiro passo".

\section{Anônimo}




\section{RESUMO}

O presente estudo teve por objetivo evidenciar as percepções dos gestores municipais quanto à existência de planejamento e coordenação por parte da União em relação ao processo de transferências voluntárias do Governo Federal. A Constituição Federal de 1988 ampliou o papel dos Estados e Municípios no arranjo federativo brasileiro. Por um lado, ampliou a base de receita, seja por meio da competência tributária própria ou por meio das transferências intergovenamentais, na tentativa de suprimir os efeitos centralizadores provocados pela Reforma Tributária de 1966. Por outro lado, descentralizou a responsabilidade de execução de políticas as quais estavam sob responsabilidade do Poder Central. Neste sentido, sob um viés descentralizador, houve uma tendência para que os recursos do orçamento fiscal e da seguridade social fossem repassados para as municipalidades, para que, em termos de parcerias intergovernamentais, executassem os projetos e as atividades de interesses recíprocos. Nas referidas parcerias é de se esperar que os recursos sejam utilizados com eficiência, além do fato de que, ao ofertar serviços, os Municípios tenham maior sensibilidade às demandas sociais. Assim, com base na hipótese no caso de ausência de planejamento e coordenação, tais acordos, apesar das potencialidades de autonomia e proximidade com a população local, podem afetar negativamente nas execuções das Políticas Públicas financiadas pela União, refletido na má utilização dos recursos. Como método de pesquisa, fez-se uso da via quantitativa, a fim de observar as características dos repasses da União, no período 2008-2015, e da via qualitativa, com base na aplicação de questionários direcionados a gestores municipais e distritais para captar as percepções sobre o processo. Como resultado foi possível evidenciar que apesar dos Estados, Municípios, do Distrito Federal e de entidades privadas sem fins lucrativos estarem próximos às demandas da população, estes não oferecem serviços eficientes à sociedade, devido aos desajustes nos processo de planejamento, gestão e controle, relacionados às transferências voluntárias de recursos do orçamento fiscal e da seguridade social da União.

Palavras-chave: Planejamento orçamentário. Gestão. Controle. Descentralização. Transferência voluntária. 


\begin{abstract}
The 1988 Constitution expanded the role of states and municipalities in the Brazilian federal arrangement. On the one hand, expanded the revenue base, either through its own taxing power or through intergovenamentais transfers in an attempt to suppress the centralizing effects of the Tax Reform 1966. On the other hand, decentralized policy implementation responsibility which they were on the Central Power responsibility. In this decentralizing route, there was a tendency for resources of the fiscal budget and social security were passed on to the municipalities, so that the form of intergovernmental partnerships, execute the projects and activities of mutual interests. In these partnerships it is expected that resources are used efficiently. Well, it is expected to offer services municipalities have a greater sensitivity to social demands. Thus, the object of the research is to show the perceptions of municipal managers as to the existence of planning and coordination by the Union in relation to this process. The hypothesis in the case of lack of planning and coordination, such agreements, despite the potential of autonomy and proximity to the local population, can actually negatively affect the execution of public policies financed by the Union, reflected in the poor use of resources. As a research method, we use two forms: a quantitative nature to observe the characteristics of the Union transfers, from 2008 to 2015; the other for a qualitative nature, was based on questionnaires aimed at municipal and district managers to capture the perceptions of the process. The results showed that despite the states, municipalities, Federal District and private entities in profit being close to the demands of the population, these do not provide efficient services to society due to mismatches in the process of planning, management and control, related to voluntary transfers resources of the fiscal budget and the Union's social security.
\end{abstract}

Keywords: Budget planning. Management. Control. Decentralizaíon. Voluntary transfer. 


\section{LISTA DE FIGURAS}

Figura 1 - Participação social na elaboração do Plano Plurianual 20162019.

Figura 2 - Defasagem temporal entre o processo eleitoral e de elaboração dos instrumentos de planejamento da União e dos Municípios...... 54

Figura 3 - Estrutura da programação orçamentária...................................... 60

Figura 4 - Análise de compatibilidade entre as programações orçamentárias da União em relação às do Governo do Distrito Federal................ 62

Figura 5 - Primeira janela de oportunidade no processo orçamentário.......... 64

Figura 6 - Segunda janela de oportunidade no processo orçamentário......... 65

Figura 7 - Atributos e função do processo de gestão.................................... 68

Figura 8 - Elementos da transparência das contas públicas......................... 80

Figura 9 - Dimensões de Accountability segundo O'Donnell.......................... 82 


\section{LISTA DE GRÁFICOS}

Gráfico 1 - Percentual de participação na captação de recursos quantidade.

Gráfico 2 - Percentuais de participação nas transferências voluntárias da União - recursos financeiros por natureza jurídica - período 2008-2015

Gráfico 3 - Valor per capita por Unidade Federativa - repasses a Entidades Públicas e Privadas sem fins lucrativos - período 2008-março de 2016

Gráfico 4- Formação dos gestores municipais que mencionaram ter graduação - unidade.

Gráfico 5 - Dedicação à atividade de captação e gestão de recursos de transferências voluntárias dos gestores municipais.

Gráfico 6 - Formação dos gestores distritais que mencionaram ter graduação -unidade.....

Gráfico 7 - Dedicação à atividade de captação e gestão de recursos de transferências voluntárias dos gestores distritais - em \%.

Gráfico 8 - Média e desvio padrão das respostas para as questões g5, g6, g7, h3, h4 e h5 


\section{LISTA DE QUADROS}

Quadro 1 - Fatores de centralização da arrecadação em Estados

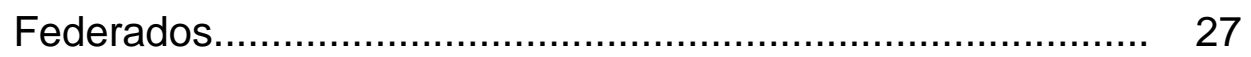

Quadro 2 - $\quad$ Competências concorrentes e competências municipais......... 38

Quadro 3- Características e objetivos das parcerias estratégicas flexíveis......................................................................... 42

Quadro 4 - $\quad$ Dimensões estratégias de parceria......................................... 43

Quadro 5 - Deslocamento em um exercício do Plano Plurianual em relação ao mandato presidencial.......................................... 49

Quadro 6- Algumas exigências estabelecidas pela Lei de Diretrizes Orçamentárias em relação às transferências voluntárias......... 56

Quadro 7- Bloco de informações quantitativas na estrutura de programação orçamentária................................................. 59

Quadro 8 - Tribunais de Contas presentes na estrutura orgânica da administração pública brasileira............................................. 73

Quadro 9- Distinção entre controles internos e órgãos de controle

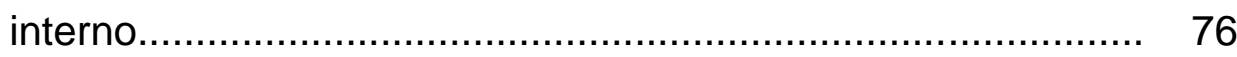

Quadro 10 - Relação de dados necessários para análise........................... 85

Quadro 11 - Questões relacionadas para o teste de significância................ 87

Quadro 12 - Localização dos respondentes municipais.............................. 111 


\section{LISTA DE TABELAS}

Tabela 1 - Repartição da receita tributária total por nível de governo Brasil - período 1992-2014...................................................... 26

Tabela 2 - Volume de recursos de transferências voluntárias da União Período 2008-março de 2015 - em R $\$$........................................ 92

Tabela 3 - Quantidade e valor regionalizado - repasses a Entidades Públicas e Privadas sem fins lucrativos - período 2008-2016 em $\mathrm{R} \$$.

Tabela 4 - Valor per capita por Unidade Federativa - repasses a Entidades Públicas e Privadas sem fins lucrativos - período 2008-2016 em $\mathrm{R} \$$

Tabela 5 - Acordos vigentes sem registro de execução - todos os partícipes - em $\mathrm{R} \$$.................................................................... 102

Tabela 6 - Prestações de contas sem recursos executados - todos os partícipes - em $\mathrm{R} \$$.

Tabela 7 - Variação dos índices de inflação e poupança - período 01/07/2008-31/05/2016 - em \%.

Tabela 8 - Atrasos na prestação de contas - todos os partícipes - em R\$... 108

Tabela 9 - Atrasos na análise da prestação de contas - órgãos da União em $\mathrm{R} \$$.

Tabela 10 - Atrasos na entrega das documentações para a prestação de contas - diversas entidades - em $\mathrm{R} \$$.

Tabela 11 - Qualificação básica dos gestores municipais - em \%

Tabela 12 - Anos de experiência no setor de lotação - gestores municipais em \%

Tabela 13 - Anos de experiência no setor de lotação - gestores distritais em \%

Tabela 14 - Resultados do questionário aplicado aos gestores distritais e municipais

Tabela 15 - Testes de Normalidade Kolmogorv-Smirnov e Shapiro-Wilk........

Tabela 16 - Resultados dos testes de comparação de médias. 
Tabela 17 - Recálculo de comparação do score médio distrital menos o score médio municipal........................................................... 142

Tabela 18 - Teste de normalidade...................................................... 144

Tabela 19 - Resultados dos testes de correlação......................................... 147

Tabela 20 - Correlação entre as variáveis................................................... 148 


\section{LISTA DE ABREVIATURAS E SIGLAS}

\begin{tabular}{|c|c|c|}
\hline ADCT & & Ato das Disposições Constitucionais Transitórias \\
\hline AGU & - & Advocacia-Geral da União \\
\hline Art. & - & Artigo \\
\hline BACEN & - & Banco Central do Brasil \\
\hline BIRD & - & Banco Interamericano de Desenvolvimento \\
\hline CDES & - & Conselho de Desenvolvimento Econômico e Social \\
\hline CF & - & Constituição Federal \\
\hline CGU & - & Controladoria-Geral da União \\
\hline CIDE - Combustíveis & - & $\begin{array}{l}\text { Contribuição de Intervenção no Domínio Econômico } \\
\text { sobre Combustíveis }\end{array}$ \\
\hline CISET & - & Secretarias de Controle Interno \\
\hline $\mathrm{CN}$ & - & Congresso Nacional \\
\hline CNJ & - & Conselho Nacional de Justiça \\
\hline CTU & - & Conta Única do Tesouro da União \\
\hline DF & - & Distrito Federal \\
\hline EFS & - & Entidades Fiscalizadoras Superiores \\
\hline EUA & - & Estados Unidos da América \\
\hline FACE & - & $\begin{array}{l}\text { Faculdade de Economia, Administração, } \\
\text { Contabilidade e Gestão de Políticas Públicas }\end{array}$ \\
\hline FCO & - & $\begin{array}{l}\text { Fundo Constitucional de Financiamento do Centro- } \\
\text { Oeste }\end{array}$ \\
\hline FMI & - & Fundo Monetário Internacional \\
\hline FNE & - & Fundo Constitucional de Financiamento do Nordeste \\
\hline FNO & - & Fundo Constitucional de Financiamento do Norte \\
\hline FPE & - & Fundo de Participação dos Estados \\
\hline FPM & - & Fundo de Participação dos Municípios \\
\hline FUNDEB & - & $\begin{array}{l}\text { Fundo de Manutenção e Desenvolvimento da } \\
\text { Educação Básica e de Valorização dos Profissionais } \\
\text { da Educação }\end{array}$ \\
\hline
\end{tabular}


ICMS

IDH

INTOSAI

IOF-Ouro

IPCA

IPI

IPI -Exportação

IR

ISS

ITR

LAI

LC

LDO

LOA

LRF

MA

MP

MTO

NGP

NPM

OCDE

OGU

PDDE

PDRAE

$\mathrm{PI}$

PNAE
Imposto sobre Operações relativas à Circulação de Mercadorias e Prestação de Serviços de Transporte Interestadual e Intermunicipal e de Comunicação Índice de Desenvolvimento Humano

Organização Internacional de Entidades Fiscalizadoras Superiores

- Imposto sobre Operações Relativas ao Metal Ouro como Ativo Financeiro

- $\quad$ Índice de Preços ao Consumidor Amplo

- Imposto sobre a Produção Industrial

- Imposto sobre a Produção Industrial Proporcional às Exportações

- Imposto de Renda

- Imposto sobre serviços de qualquer natureza

- Impostos sobre a Propriedade Territorial Rural

- Lei de Acesso a Informação

- Lei Complementar

- Lei de Diretrizes Orçamentárias

- Lei Orçamentária Anual

- $\quad$ Lei de Responsabilidade Fiscal

- $\quad$ Modalidade de Aplicação

- Ministério do Planejamento, Orçamento e Gestão

- Manual Técnico do Orçamento

- Nova Gestão Pública

- New Public Management

- Organização para a Cooperação e Desenvolvimento Econômico

- $\quad$ Orçamento Geral da União

- Programa Dinheiro Direto na Escola

- Plano Diretor da Reforma do Aparelho do Estado

- Portaria Interministerial

- Programa Nacional de Alimentação Escolar 
PNATE

PPA

PPGE

$\mathrm{SCl}$

SICONV

STN

SUS

TCU

UnB
Programa Nacional de Apoio ao Transporte do Escolar

- Plano Plurianual

- Programa de Pós-Graduação em Economia

- Secretaria de Controle Interno

- Sistema de Gestão de Convênios e Contratos de Repasses

- Secretaria do Tesouro Nacional

- Sistema Único de Saúde

- Tribunal de Contas da União

- $\quad$ Universidade de Brasília 
1 INTRODUÇÃO

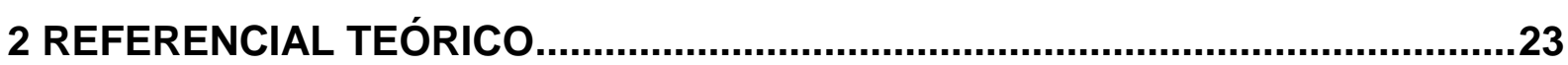

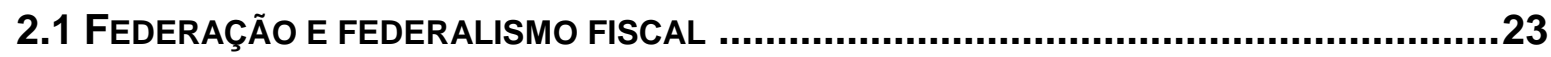

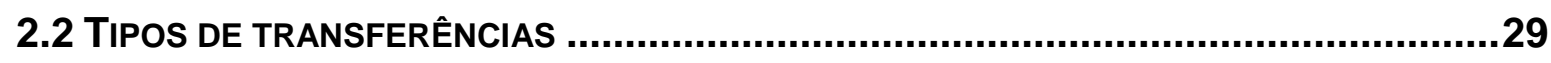

2.3 FEDERALISMO E DESCENTRALIZAÇÃo dE COMPETÊNCIAS ....................................31

2.4 REPARTIÇÃO DE COMPETÊNCIAS CONSTITUCIONAIS EM RELAÇÃO AO GASTO............36

2.5 RELAÇÕES INTERORGANIZACIONAIS NO PROCESSO DE IMPLEMENTAÇÃO DAS POLÍTICAS PÚBLICAS FINANCIADAS PELAS TRANSFERÊNCIAS VOLUNTÁRIAS DA UNIÃO ..39 2.6 O PROCESSO DE PLANEJAMENTO ORÇAMENTÁRIO, GESTÃO E CONTROLE DAS POLÍTICAS PÚBLICAS FINANCIADAS POR TRANSFERÊNCIAS VOLUNTÁRIAS DA UNIÃO.......48

2.6.1 Planejamento orçamentário ................................................................48

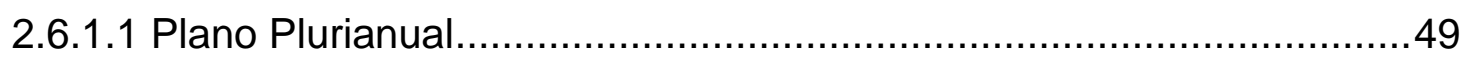

2.6.1.2 A Lei de Diretrizes Orçamentárias ..................................................54

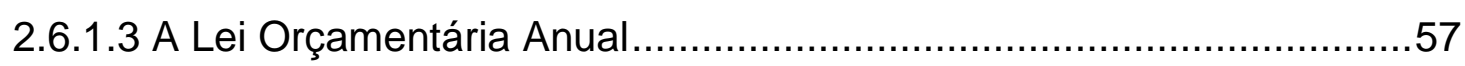

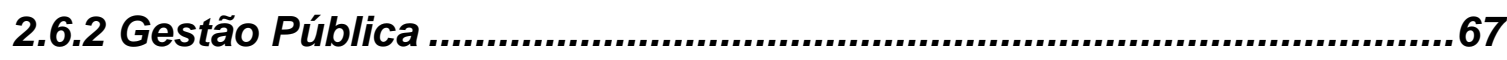

2.6.3 Atividade de controle sobre a Gestão Pública ...................................70

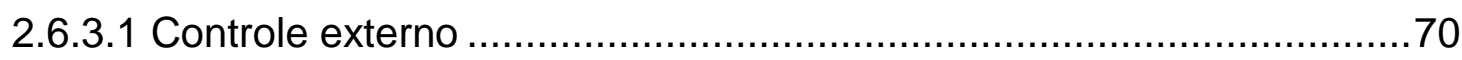

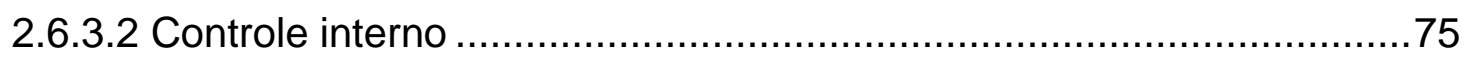

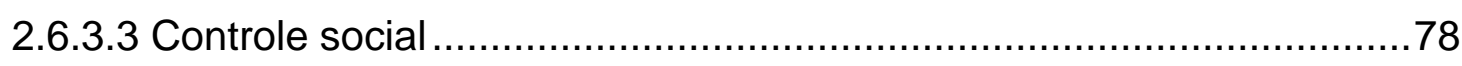

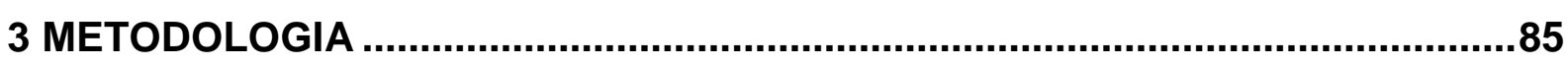

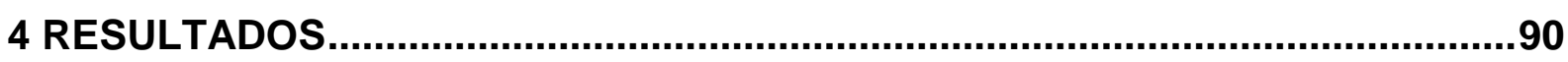

4.1 ANÁlISE QUANTITATIVA: CARACTERÍSTICAS GERAIS E ESPECífICAS DOS REPASSES

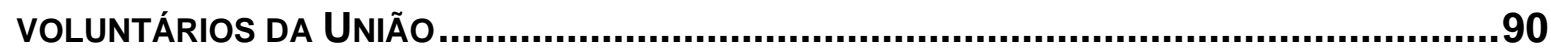

4.1.1 Características nos repasses de recursos de transferências

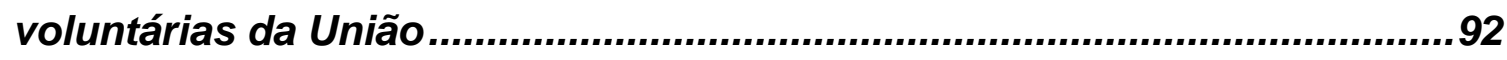

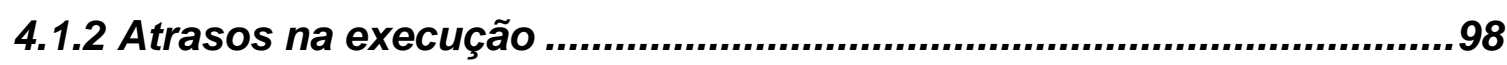

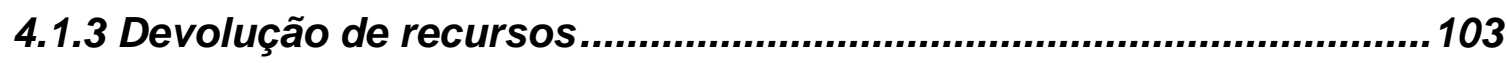

4.1.4 Redução do poder de compra dos recursos transferidos.................105

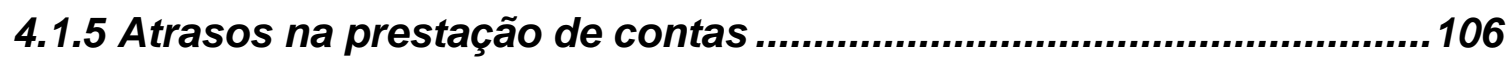

4.2 ANÁLISE QUALITATIVA: AVALIAÇÃo QUANTO ÀS PERCEPÇÕES LEVANTADAS EM RELAÇÃO AO PROCESSO DE TRANSFERÊNCIAS DE RECURSOS 
4.2.1 Qualificação dos respondentes. 110

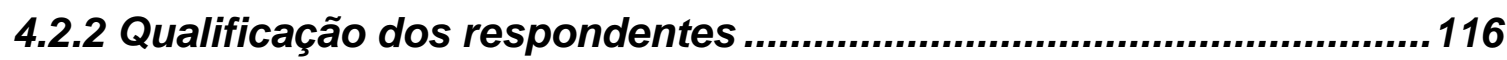

4.2.3 Análise da comparação das médias..............................................135

4.2.4 Teste de comparação de medis deMann-Whitney............................139

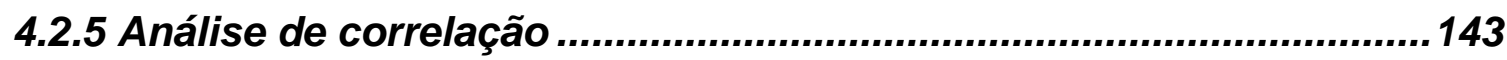

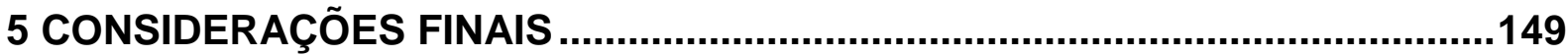

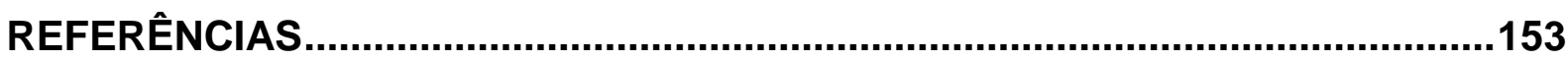

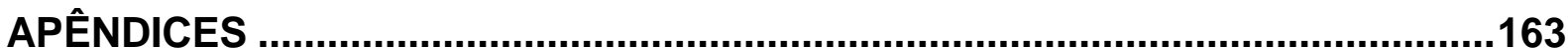

APÊNDICE "A" - TABELA INDICANDO VALOR DE REPASSE POR NATUREZA

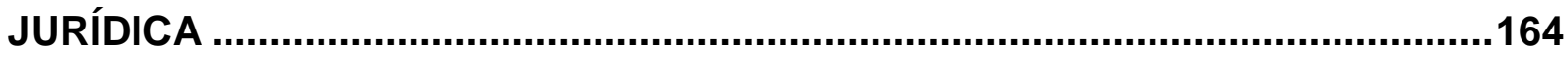

APÊNDICE "B" - TABELA INDICANDO AS TRANSFERÊNCIAS VOLUNTÁRIAS DA UNIÃO POR FAIXA DE VALOR ........................................................165 APÊNDICE "C" - TABELAS INDICANDO O TEMPO DE VIGÊNCIA DOS ACORDOS EM EXECUÇÃO ....................................................................167

APÊNDICE "D" - TABELAS INDICANDO ACORDOS COM PRESTAÇÕES DE CONTAS SEM RECURSOS EXECUTADOS ...................................................173

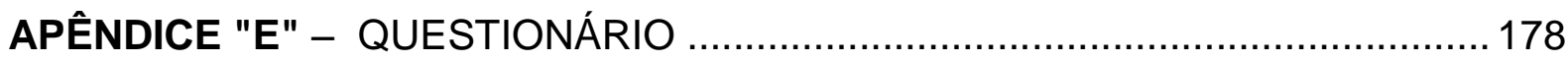




\section{INTRODUÇÃO}

A Administração Pública, em geral, tem se voltado para a busca pela eficiência na utilização dos recursos devido à existência de restrições orçamentárias e recursos técnicos, a fim de atender as contínuas e crescentes necessidades sociais e de infraestrutura para o desenvolvimento econômico.

Neste sentido, nas administrações dos diferentes níveis de governo são criados ou aperfeiçoados processos e inter-relacionamentos para a melhor utilização dos recursos disponíveis, sendo uma dessas ações a implementação de Políticas Públicas realizadas com esforços conjuntos (financeiros ou técnicos), entre o setor público-público ou público-privado.

No intuito de ganho de eficiência na alocação dos recursos do orçamento fiscal e da seguridade social da União, diversos objetos de Políticas Públicas previstos nas peças orçamentárias da União são executados de forma descentralizada, por meio das transferências voluntárias do orçamento fiscal e da seguridade social da União, por parte dos entes subnacionais, somados também os esforços de entidades privadas sem fins lucrativos.

A inter-relação entre diferentes organizações dos entes federativos, ou entre estas e as entidades privadas sem fins lucrativos, traduz-se em uma alternativa para a realização dos planos públicos em benefício aos seus destinatários: a sociedade. Além do que é uma alternativa no que tange à escassez de recursos financeiros aos entes subnacionais.

Outro argumento relacionado à execução indireta é de que os Estados, os Municípios, o Distrito Federal e as entidades privadas sem fins lucrativos, ao estarem mais próximos das demandas da população, poderiam oferecer bens e serviços de melhor qualidade à sociedade, em contraponto ao que seria ofertado de forma centralizada.

No entanto, as relações federativas envolvendo os 03 (três) níveis de governo em um País de proporções continentais como o Brasil, que envolve 5.570 municípios, 26 Estados, um Distrito Federal e um Governo Central, conforme Rocha (2015, p. 16), "apresentam um elevado grau de complexidade, fruto das interações cooperativas e conflituosas, inerente à alocação de responsabilidades". 
A interface entre o setor público dos 03 (três) níveis federados para as implementações das Políticas Públicas de interesses mútuos podem enfrentar grandes dificuldades em relação à autonomia e coordenação entre as entidades envolvidas.

$\mathrm{Na}$ referida relação, o processo de planejamento público pode não ter um devido alinhamento entre os planos de cada um dos partícipes, seja por divergências quanto às políticas a serem executadas, seja pelas vertentes ideológico-partidárias, ou seja pela divergência relativa ao lapso temporal de discussão e aprovação dos próprios planejamentos, no que pode interferir no alinhamento das estratégias e na sua própria execução.

A título de exemplo, para esse último caso, há um descasamento temporal no processo de planejamento da União para com os dos municípios, ou seja, um interstício de 02 (dois) anos entre o Plano Plurianual (PPA) da União para com os planos das municipalidades, no que afeta no desenho das parcerias entre tais entidades públicas nas leis orçamentárias anuais, refletindo, de forma negativa, no processo de planejamento e execução das políticas propostas à execução descentralizada.

A consequência do desalinhamento nas estratégias é a elaboração e a identificação retardatária de programas orçamentários compatíveis, impactando, assim, na elaboração de propostas de parcerias, nos atrasos na execução dos acordos firmados, nos ajustes no plano de trabalho devido à elaboração incompleta de projetos em consequência de prazos insuficientes e nas inexecuções dos acordos.

Os acordos firmados entre diferentes instâncias administrativas do setor público, e destas com entidades privadas, por meio de convênios, contratados de repasses e termos de colaboração ou de fomento, podem não atingir a esperada eficiência nas operações devido a falhas ou ausências de um processo planejado para a formulação das parcerias e a coordenação em relação ao monitoramento da execução dos acordos firmados.

Logo, por hipótese, no caso de não haver um processo planejado e coordenado por parte da União, bem como da não observação das capacidades operacionais das municipalidades, apesar das potencialidades de autonomia e proximidade com a população local, os repasses, em verdade, podem afetar 
negativamente a execução das Políticas Públicas, devido a atrasos na execução ou mesmo a inexecução parcial ou total dos acordos.

A presente pesquisa tem por justificativa contribuir para a geração de informações e conhecimento em relação à transferência de recursos voluntários intergovernamentais, mediante convênios e congêneres, da União, sobretudo, para os Municípios, bem como evidenciar algumas percepções dos gestores de recursos de transferências voluntárias municipais e distritais, mediante a aplicação de questionário, no intuito de se obter informações sobre o planejamento, a gestão e o controle, para fomentar a discussão a respeito da melhoria de gestão dos recursos da União transferidos.

Diante do exposto, o problema da pesquisa pode ser assim definido: a atual sistemática de repasses de recursos voluntários da União permite que as entidades parceiras atuem de forma coordenada com a mesma, no que tange o planejamento orçamentário, gestão e controle?

O objetivo geral da presente pesquisa é o de levantar as percepções de gestores públicos municipais e do Distrito Federal ${ }^{1}$ em relação à existência de um processo planejado e coordenado de repasses de recursos voluntários do orçamento fiscal e da seguridade social da União, para tais entes federados, na ótica da avaliação do planejamento, gestão e controle.

Quanto aos objetivos específicos, têm-se os que se seguem:

- Evidenciar as características dos repasses dos recursos de transferências voluntárias do orçamento fiscal e da seguridade social da União para os entes subnacionais e entidades privadas sem fins lucrativos;

- Avaliar se o modelo atual de repasses de recursos permite a antecipação de programas passíveis de acordos e a proposições de projetos exequíveis;

- Identificar se os gestores municipais têm razoável conhecimento sobre o fluxo de planejamento orçamentário, em vistas de antecipar o processo de captação de recursos; e

- Avaliar se o atual sistema de distribuição de recursos de transferências voluntárias atende ao planejamento, à gestão ou ao controle.

\footnotetext{
1 O Distrito Federal foi incluído na pesquisa devido a sua característica anômala de funções de
} Estado e Município. 
O presente estudo foi estruturado em 05 (cinco) partes, conforme a discriminação a seguir. Além desta introdução, na segunda parte tem-se o referencial teórico, que traz um apanhado sobre o federalismo fiscal brasileiro, a repartição de competências quanto ao gasto e os tipos de transferências no sistema de repartição de receitas presentes no País, bem como uma abordagem das relações interorganizacionais no processo de execução indireta de Políticas Públicas por meio das transferências voluntárias da União, seguidas do processo orçamentário, de gestão e de controle envolvido na execução, por partes dos entes subnacionais.

$\mathrm{Na}$ terceira parte tem-se a metodologia utilizada para atingir a proposta da Dissertação, que foi dividida em 02 (duas) partes, a saber: 1) uma análise quantitativa dos dados extraídos da base de dados do Sistema de Gestão de Convênios e Contratos de Repasses (SICONV) (sistema federal implantado em entre os anos de 2007 e 2008), no intuito de identificar algumas características dos repasses da União às diversas entidades públicas ou privadas sem fins lucrativos; e, 2) de característica qualitativa, refere-se à análise dos dados levantados por meio de questionário enviado a um grupo de discussão on line de gestores de recursos de transferências voluntárias, no intuito de evidenciar as percepções destes em relação à sistemática de repasses de recursos efetuados pelos órgãos federais.

$\mathrm{Na}$ quarta parte tem-se o tratamento da questão central da presente pesquisa: a existência ou não de planejamento e coordenação entre os formuladores (Administração Pública federal) e implementadores (Administrações Públicas municipais) em relação às políticas públicas executadas por meio das transferências voluntárias do orçamento fiscal e da seguridade social da União. Neste sentido, realizaram-se análises descritivas quanto às características dos repasses federais aos entes subnacionais e entidades privadas sem fins lucrativos e sobre os dados coletados por meio de questionários enviados a gestores das Administrações Públicas municipais participantes de um fórum eletrônico de discussões em relação às transferências voluntárias da União.

$\mathrm{Na}$ quinta e última parte tem-se as evidências levantadas na presente pesquisa e as considerações finais, com o auxílio da revisão bibliográfica empreendida. 


\section{REFERENCIAL TEÓRICO}

\subsection{Federação e federalismo fiscal}

O federalismo, em uma definição básica, conforme Elazar (1987 apud ABRUCIO; SANO, 2013), consiste na divisão do poder e a autoridade entre as esferas governamentais, garantida por um contrato maior - a Constituição -, tendo como principal característica a combinação entre a autonomia e a interdependência das partes.

De origem estadunidense, segundo Branco (2011), o federalismo surgiu como resposta à necessidade de um governo eficiente em vasto território, que, ao mesmo tempo, assegurasse os ideais republicanos que vingaram com a revolução de 1776.

Por influência norte-americana, a forma de estado federativo foi a opção brasileira desde a sua primeira constituição republicana, datada de 1891. Porém, naquele primeiro momento, a nação vivia um federalismo dicotômico formado por 02 (dois) entes, a saber: 1) a União (poder central); e, 2) os Estados membros. Os Municípios, então, constituíam uma extensão dos Estados membros sem autonomia - situação que se manteve até metade do século XX (MEIRELES, 1996, apud BATISTA, 2012).

Com a Constituição Federal (CF) de 1988, ao lado da União e dos Estados, os Municípios passam a ter status de entidade política, integrando a Federação, com prerrogativas de auto-organização ${ }^{2}$, autolegislação ${ }^{3}$, autogoverno ${ }^{4}$ e autoadministração ${ }^{5}$, com poderes conferidos pelo próprio texto constitucional dentro de sua área de atuação.

Segundo Cunha (2004), nos Estados Federais, os entes federativos são dotados de autonomia, que, respeitados os limites constitucionais, é materializada em organização administrativa própria, em competência tributária específica, em responsabilidade por determinadas Políticas Públicas, em poder para editar leis em

2 Prerrogativa de auto-organização por meio da elaboração de suas próprias leis orgânicas, ao mesmo modo da Constituição Federal ou Estadual, no entanto, sobre o prisma de haver compatibilidade entre elas.

${ }^{3}$ Prerrogativa de emitir leis próprias dentro das competências estabelecidas pela Constituição Federal (CF).

4 Prerrogativa de eleição de seus agentes políticos sem a interferência direta da União ou dos estados.

${ }^{5}$ Prerrogativa de exercer suas competências administrativas, tributárias e legislativas, no âmbito de sua competência, sem interferências de poder externo. 
suas esferas de competências de forma simultânea; mas os referidos entes federativos são interdependentes.

Neste sentido, tem-se aí a fórmula adotada pelo Poder Constituinte na elaboração da atual Constituição do Brasil, onde, segundo o disposto em seu art, 18, in verbis:

Art. 18. A organização político-administrativa da República Federativa do Brasil compreende a União, os Estados, o Distrito Federal e os Municípios, todos autônomos, nos termos desta Constituição.

Segundo Rosen e Gayer (2015), um sistema federal é composto de diferentes níveis de governo que fornecem bens e serviços públicos e que tem alguma margem de manobra para tomar decisões. O tema "federalismo fiscal" examina as funções realizadas pelos diferentes níveis de governo e como estes interagem uns com os outros.

Conforme Andrada (2012, p. 206), é preciso observar que

[...] a federação é uma técnica poderosa de organização política, que tende a fortalecer em dimensões mais extensas dentro do território mundial. [...] no século XX e mesmo no século XIX, vai constituir-se em organizações políticas modernizadas, concretizando uma reunião de entidades políticas que se submetem a uma forma técnica de dominação juridicamente entrosada e definida nas suas respectivas atribuições.

No entanto, não se pode tratar da autonomia sem os recursos apropriados. Assim, Andrada (2012) faz uma ressalva em relação à constituição de territórios federais. Para aquele autor, muitos países que se apresentam como federação, como, por exemplo, o Brasil e a Argentina, e em realidade, vivem situação de domínio do poder central.

No caso brasileiro, o domínio centralista - uma mitigação do regime federalista - é uma consequência dos períodos autoritários e antidemocráticos existentes na construção histórica do País - fato que se reflete nas elaborações legislativas, aduzindo que estas não estejam desconectadas do seu contexto, ou seja, as normas em períodos de baixo grau democrático acabam por apresentar um viés centralizador. 
Nas últimas décadas tem sido debatida e instituída a necessidade de descentralização fiscal a nível mundial. Sobre a questão, assevera Bahl (1999, p. 1): "É raro o país que não tenha colocado o fortalecimento do governo local na sua agenda política de desenvolvimento".

Aquele autor ainda destaca que apesar de pronunciamentos, planos e promessas, não houve uma corrida para dotar os governos subnacionais com competências fiscais significativas e maior autonomia de despesa.

Neste sentido, e retomando para o caso do federalismo brasileiro, segundo Cardozo (2007), a reforma tributária ${ }^{6}$ da década de 1960 instituiu um sistema tributário centralizador, onde grande parte dos impostos estavam sob competência da União, que possuía também o poder de manipular as alíquotas dos impostos pertencentes às esferas subnacionais de governo, bem como influenciar as receitas de Estados e Municípios por meio de transferências.

Assim, com a Reforma Tributária de 1966, Andrada (2012) afirma que o centralismo feriu o sistema federativo brasileiro, tendo em vista que Estados e Municípios perderam autonomia para a geração de seus próprios recursos, bem como o poder de decisão sobre seus gastos, em virtude da proliferação do sistema de vinculação de receitas.

O fato é que, no período recente, é possível observar uma tendência centralizadora da arrecadação tributária na União. Conforme série histórica sobre o percentual de receita tributária pelo setor público consolidado, apresentada na Tabela 1, a seguir, é possível verificar que no período 1992-2003, houve uma apropriação da receita na média de $58,42 \%$, do total arrecadado pelos pelas 03 (três) instâncias federativas (com um desvio padrão de 0,042); e no período 20042014, houve uma significativa apropriação de parcelas superiores a $68 \%$ da receita tributária no País, com destaque para os anos de 2007 e 2011, onde o percentual de participação da União superou os $70 \%$.

\footnotetext{
6 Vide Lei n. 5.172, de 25 de outubro de 1966, que instituiu o Código Tributário Nacional, recepcionado pela Constituição Federal (CF) de 1988. Passados 49 anos de sua publicação, ainda é o dispositivo que regra as matérias tributárias entre União, Estados, Municípios e Distrito Federal.
} 
Tabela 1 - Repartição da receita tributária total por nível de governo - Brasil - período 1992-2014.

\begin{tabular}{|c|c|c|c|c|}
\hline \multirow{2}{*}{ Ano } & \multicolumn{3}{|c|}{ Nível de Governo } & \multirow{2}{*}{ Total (\%) } \\
\hline & União (\%) & Estados (\%) & Municípios (\%) & \\
\hline 1992 & 53,77 & 38,68 & 7,54 & 100 \\
\hline 1993 & 51,15 & 34,74 & 4,11 & 100 \\
\hline 1994 & 59,50 & 35,90 & 4,60 & 100 \\
\hline 1995 & 56,95 & 36,85 & 6,20 & 100 \\
\hline 1996 & 56,22 & 37,29 & 6,49 & 100 \\
\hline 1997 & 58,08 & 35,21 & 6,71 & 100 \\
\hline 1998 & 58,64 & 34,63 & 6,73 & 100 \\
\hline 1999 & 60,90 & 32,88 & 6,22 & 100 \\
\hline 2000 & 59,99 & 33,89 & 6,12 & 100 \\
\hline 2001 & 68,70 & 26,80 & 4,50 & 100 \\
\hline 2002 & 59,41 & 34,09 & 6,50 & 100 \\
\hline 2003 & 57,72 & 35,10 & 7,18 & 100 \\
\hline 2004 & 69,72 & 26,06 & 4,62 & 100 \\
\hline 2005 & 69,60 & 25,51 & 4,89 & 100 \\
\hline 2006 & 69,32 & 25,60 & 5,09 & 100 \\
\hline 2007 & 70,08 & 24,77 & 5,14 & 100 \\
\hline 2008 & 69,51 & 25,36 & 5,14 & 100 \\
\hline 2009 & 68,91 & 25,63 & 5,46 & 100 \\
\hline 2010 & 69,03 & 25,45 & 5,52 & 100 \\
\hline 2011 & 70,04 & 24,44 & 5,53 & 100 \\
\hline 2012 & 69,11 & 25,11 & 5,78 & 100 \\
\hline 2013 & 68,96 & 25,22 & 5,82 & 100 \\
\hline 2014 & 68,47 & 25,35 & 6,19 & 100 \\
\hline
\end{tabular}

Fonte: Receita Federal do Brasil (2015).

Por outro lado, a parcela registrada para Estados e Municípios considerando o Distrito Federal - no período 1993-2014, teve reduções, com picos de variação que sequer atingiram o nível de participação registrado no exercício financeiro de 1992 (o maior nível de participação ali registrado é de 38,68\% e 7,54\%, respectivamente, para Estados e Munícipios).

Baião (2013), com base em um levantamento bibliográfico, apontou 03 (três) fatores que justificam a existência de algum grau de centralização da arrecadação nas federações, dispostos no Quadro 1, a seguir. 
Quadro 1 - Fatores de centralização da arrecadação em Estados Federados.

\begin{tabular}{|c|c|c|}
\hline Primeiro Fator & Segundo Fator & Terceiro Fator \\
\hline $\begin{array}{l}\text { Necessidade de atribuir os } \\
\text { principais impostos ao } \\
\text { governo central, a fim de } \\
\text { garantir a eficiência do } \\
\text { sistema tributário. Centralizar } \\
\text { alguns impostos reduz o custo } \\
\text { no atendimento de diversas } \\
\text { legislações (compliance costs) } \\
\text { incorridas pelos agentes } \\
\text { econômicos, além d diminuir o } \\
\text { risco de governos } \\
\text { subnacionais ferirem o } \\
\text { princípio da neutralidade ou } \\
\text { até realizarem competições } \\
\text { fiscais, à medida que alteram } \\
\text { suas alíquotas. }\end{array}$ & $\begin{array}{l}\text { Necessidade de promover a } \\
\text { equidade entre os governos } \\
\text { subnacionais, que geralmente } \\
\text { apresentam capacidades de } \\
\text { arrecadação diferentes, bem } \\
\text { como demandas da população } \\
\text { e respectivos e distintos custos } \\
\text { de atendimento. A diferença } \\
\text { entre os governos subnacionais } \\
\text { recebe o nome de brecha } \\
\text { horizontal, e representa o } \\
\text { motivo das transferências } \\
\text { distributivas, que visam atenuar } \\
\text { a desigualdade entre Estados e } \\
\text { Municípios. }\end{array}$ & $\begin{array}{l}\text { Necessidade de alocar os } \\
\text { recursos de maneira seletiva e } \\
\text { discricionária, a fim de realizar } \\
\text { projetos e objetivos nacionais. } \\
\text { Neste caso, impõem-se } \\
\text { condições para o uso do } \\
\text { dinheiro, o que permite } \\
\text { controlar o alcance dos } \\
\text { resultados do projeto. E ainda, } \\
\text { a despeito da possibilidade de } \\
\text { controlar o uso do recurso e } \\
\text { atender, assim, os objetivos } \\
\text { que transcendem a esfera } \\
\text { municipal, as transferências } \\
\text { condicionadas criam resistência } \\
\text { entre os governos } \\
\text { subnacionais, que passam a ter } \\
\text { sua autonomia restringida. }\end{array}$ \\
\hline
\end{tabular}

Fonte: Baião (2013).

Já para Bahl (1999, p. 24), a justificativa de uma maior centralização fiscal está no trade off entre a estabilização macroeconômica e a descentralização de receitas e despesas, ou seja: "Hiperinflação ou recessão oferece muito mais uma ameaça à reeleição do que a ausência de um bom programa de descentralização".

Os referidos fatores acarretam no sistema federativo fiscal consideráveis disparidades entre as fontes de receitas e as obrigações de despesa entre os Estados-Membros de uma Federação. Neste sentido, segundo Martinez-Vazquez e Sepulveda (2011), as descentralizações de despesa são geralmente mais difundidas do que a descentralização de receitas, e as transferências intergovernamentais são chamadas para desempenhar um papel crucial no equilíbrio fiscal de quase todos os sistemas fiscais descentralizados.

Bahl (2000) destaca o desequilíbrio entre as responsabilidades de despesa de governos subnacionais e seus poderes para aumentar as receitas. Nas fases iniciais do desenvolvimento, as prioridades de responsabilidades do setor público são o desenvolvimento da infraestrutura e a prestação de necessidades básicas de vida, além da proteção da estabilidade econômica. Para aquele autor, tais ações determinam a centralização. Mas, com o crescimento econômico e a urbanização, tem-se uma tendência para que a despesa pública se desloque para serviços prestados pelos governos locais, como, por exemplo, serviços sociais, 
abastecimento de água etc. O resultado é uma incapacidade dos governos locais em fornecerem níveis adequados de serviços públicos. A lacuna deverá ser preenchida ofertando aos governos locais mais poderes sobre a receita ou via transferências de receitas do governo central para os governos subnacionais.

Blöchliger e King (2006), em artigo relacionado à autonomia fiscal dos governos subnacionais nos países da Organização para a Cooperação e Desenvolvimento Econômico (OCDE), observaram também o fato de que na maioria dos países analisados na pesquisa, os gastos dos governos subnacionais excedem os recursos fiscais, sendo que o gap fiscal alargou-se nas últimas décadas. Segundo aqueles autores, enquanto a parcela de gastos subnacionais aumentou a competência tributária local, com algumas exceções, permaneceram praticamente estáveis.

Filellini (1994) classifica as disparidades existentes como fontes de receitas e obrigações de despesas em desequilíbrio vertical e desequilíbrio horizontal. 0 primeiro caso pode ser observado entre níveis de governo, originadas, em geral, devido a maior elasticidade de renda da base tributária de competência de um governo - quase sempre federal - contrastada com as baixas elasticidades das receitas dos governos estaduais e municipais. Ou seja, ao centralizar a arrecadação de receitas, a União possui maior flexibilidade na gestão tributária, com alterações de alíquotas e bases de cálculos dos tributos de sua ampla competência, em contraste com Estados e Municípios que possuem margem estreita quanto à gestão dos tributos de suas competências. Logo, uma maior flexibilidade na tributação possibilita mais receita e maior potencial para o gasto público.

Já para a segunda situação, segundo Filellini (1994), o desequilíbrio se dá entre diferentes unidades administrativas do mesmo nível, resultante de consideráveis diferenças entre as áreas econômicas da nação, na distribuição per capita da renda e riqueza, bem como do volume das transações existentes.

Assim, a arrecadação de determinados tributos estaduais e municipais, com suas incidências, variam conforme o volume de atividade econômica. Como exemplo, impostos como o Imposto sobre Operações Relativas à Circulação de Mercadorias e sobre Prestação de Serviços de Transporte Interestadual e Intermunicipal e de Comunicação (ICMS) ou o Imposto Sobre Serviços (ISS) tem forte correlação com a atividade econômica dos Estados e Municípios, refletindo-se em conflitos entre os Estados-Membros, devido a manobras tributárias para a 
atração de investimentos, e causando diferenciações também no nível de disponibilidade de soluções públicas às demandas sociais, o que amplia as disparidades regionais.

Continuando com Filellini (1994), os desequilíbrios verticais e horizontais, somados, refletem no volume per capita dos bens públicos produzidos pelas diversas jurisdições. Ainda conforme aquele autor, uma forma de minorar os efeitos desses desequilíbrios no bem-estar da população impactada negativamente são as transferências intergovernamentais de recursos para compensar diferenciais regionais de renda, ou mesmo custos e benefícios externos gerados por certas ações locais.

As transferências de receitas, pertencentes ao nível do governo repassador, podem ou não estar vinculadas a condicionalidades ou contrapartidas a serem observadas pelo ente recebedor.

\subsection{Tipos de transferências}

Prado (2007 apud BAIÃO, 2013) observou que na totalidade de federações em todo o mundo, os governos dos níveis superiores arrecadam mais do que gastam, enquanto os de níveis inferiores gastam mais do que arrecadam. Segundo aquele autor, tal situação recebe o nome de brecha vertical, e explica porque todas as federações fazem uso de transferências verticais.

No intuito de suavizar os impactos da centralização fiscal, a CF de 1988 buscou por mecanismos que pudessem direcionar as parcelas dos recursos arrecadados pelo Poder Central às unidades subnacionais, criando, assim, o Fundo de Participação dos Municípios (FPM), o Fundo de Participação dos Estados (FPE) e as transferências fundo a fundo, a exemplo do Fundo de Manutenção e Desenvolvimento da Educação Básica e de Valorização dos Profissionais da Educação (FUNDEB) etc.

Tem-se ainda outro modo de repasses de recursos para as entidades subnacionais, presentes no arcabouço normativo do poder central: as transferências voluntárias de recursos do orçamento fiscal e da seguridade social do Orçamento Geral da União (OGU). 
Em síntese, a União dispõe de 03 (três) modalidades de transferências de recursos financeiros aos entes subnacionais, a saber: 1) constitucionais; 2) legais; e, 3) voluntárias.

As primeiras, derivadas do próprio texto da CF de 1988, constituem-se da partilha do quantum tributário arrecadado de competência da União para Estados, Municípios e Distrito Federal, para que sejam alocadas em funções estatais específicas.

Algumas dessas transferências constitucionais têm regras ou percentuais de participação definida no próprio texto constitucional, tais como: transferências de recursos para a educação (o FUNDEB, por exemplo), que centraliza uma parcela de tributos $(20 \%)$ arrecadados por todas as esferas governamentais para aplicação naquele setor, de acordo com as regras preestabelecidas, distribuídos entre cada Estado e seus Municípios, proporcionalmente ao número de alunos das diversas etapas e modalidades da educação básica presencial ${ }^{7}$; os repasses para a saúde, entre outros aspectos.

Quanto ao FPM e FPE, constituem-se de parcelas arrecadadas do Imposto de Renda (IR) e do Imposto sobre a Produção Industrial (IPI) - impostos de competência da União. É preciso observar que compete ao Tribunal de Contas da União (TCU) fixar os coeficientes de repartição (CF 88, art. 161, parágrafo único), cabendo à Secretaria do Tesouro Nacional (STN) efetuar as transferências financeiras aos entes federados, nos prazos legalmente estabelecidos.

Outros tributos arrecadados pela União e partilhados entre os entes federados por essa modalidade de transferências constitucionais são: o Imposto sobre a Propriedade Territorial Rural (ITR), Imposto sobre a Produção Industrial Proporcional às Exportações (IPI-Exportação), a Contribuição de Intervenção no Domínio Econômico sobre Combustíveis (CIDE-Combustíveis) e o Imposto sobre Operações Relativas ao Metal Ouro como Ativo Financeiro (IOF-Ouro).

Conforme a definição da Controladoria-Geral da União (CGU), entende-se por transferências legais

[...] as parcelas das receitas federais arrecadadas pela União, repassadas aos Estados, ao Distrito Federal e aos Municípios, previstas em leis específicas. Essas leis determinam a forma de habilitação, a transferência, a aplicação dos recursos e como deverá ocorrer a respectiva prestação de

\footnotetext{
7 Vide Constituição Federal de 1988, art. 60, incs. I e II.
} 
contas. Dentre as principais transferências da União para os Estados, o DF e os Municípios, previstas em leis, destacam-se: o Programa Nacional de Alimentação Escolar (PNAE), o Programa Nacional de Apoio ao Transporte do Escolar (PNATE), o Programa Dinheiro Direto na Escola (PDDE), o Programa de Apoio aos Sistemas de Ensino para Atendimento à Educação de Jovens e Adultos, entre outros.

Por último, as transferências voluntárias são repasses financeiros onde um ente federado dispõe a outro ou a uma entidade privada sem fins lucrativos, para que estes executem, na forma de parcerias, determinados objetos de Políticas Públicas de interesses mútuos.

Os recursos financeiros da União repassados pela referida modalidade aos entes subnacionais tem objetos específicos e interesses comuns, devendo estar previstos no orçamento fiscal ou da seguridade social, das peças orçamentárias anuais de ambos os partícipes.

No caso das entidades privadas sem fins lucrativos, o objeto do acordo deve estar alinhado à missão institucional da organização.

A característica de estarem previstos nas peças orçamentárias, no caso dos repasses entre entidades públicas, é o que mais se diferencia dos repasses constitucionais. Estes são repassados pela STN, com a transferência automática da conta Única da União, para os Estados, os Municípios e o Distrito Federal; aqueles são realizados entre os órgãos da administração direta e indireta federal, estadual, municipal e do Distrito Federal, seguindo as fases de orçamentação pública (previsão, empenho, liquidação e pagamento).

Os repasses voluntários aos entes subnacionais são ajustados por meio de convênios ou contratos de repasses, e não podem decorrer de determinação constitucional ou legal ou para o Sistema Único de Saúde (SUS) ${ }^{8}$.

\subsection{Federalismo e descentralização de competências}

O exercício das funções governamentais pode ser realizado por 03 (três) formas básicas de organização política: 1) a centralização, que corresponde à forma unitária de governo, onde as funções fiscais competem exclusivamente ao governo

\footnotetext{
${ }^{8}$ A Lei complementar n. 101/2000 tratou de definir por transferência voluntária a entrega de recursos correntes ou de capital a outro ente da Federação, a título de cooperação, auxílio ou assistência financeira, que não decorra de determinação constitucional, legal ou os destinados ao Sistema Único de Saúde (SUS).
} 
central; 2) a total descentralização, representado modelo teórico em que os governos subnacionais assumiriam o papel do exercício das funções vinculadas à política fiscal; e, 3) a forma federativa, que contempla a combinação de competências centralizadas e descentralizadas em um modelo de responsabilidades compartilhadas entre os níveis de governo (ROCHA, 2015).

O Regime Federativo foi a opção brasileira para a organização políticaadministrativa. Conquanto, ao tratar aqui a questão da federação e das interlocuções entre os diversos entes componentes da federação brasileira, conforme Souza (1998, p. 50), "é de fundamental importância discutir a questão das políticas públicas tomando como base os postulados teóricos que conformam o federalismo e a descentralização".

No entanto, antes de ater-se ao federalismo e à descentralização, faz-se necessária uma distinção entre a descentralização e a desconcentração.

Para Malmegrin (2010), a desconcentração representa apenas a distribuição da responsabilidade pela execução operacional das atividades dos projetos e programas, sem transferência de recursos e autonomia decisória. Já a descentralização pode ser entendida como a transferência de recursos e de capacidade decisória de instâncias superiores para unidades espacialmente menores, conferindo capacidade às unidades comunitárias e municipais de escolher e definir as próprias prioridades na gestão de programas e projetos.

A desconcentração seria, assim, apenas uma técnica de organização administrativa, sem delegação de autoridade ou autonomia, diferente da descentralização, onde se têm ambas as características. Sobre a questão, Malmegrin (2010) aponta que a capacidade decisória e a disponibilidade de recursos são 02 (dois) aspectos fundamentais nos processos de descentralização e ausentes nos processos de desconcentração, influenciando, assim, a gestão nas unidades locais.

Portanto, segundo Espinosa (2012), a descentralização pode ser concebida como o processo pelo qual os governos centrais, sejam eles Estados unitários ou federais, transferem ou compartilham o poder e a autoridade com os governos estaduais e os Municípios, o que se concretiza através da transferência de recursos e funções. Difere da desconcentração, uma vez que, nesta última, figura o ente desconcentrador que mantém a autoridade, e o ente desconcentrado somente 
assume algumas funções que the são delegadas. Ele não dispõe de personalidade jurídica, nem patrimônio próprio, mas apenas de autonomia técnica.

A descentralização no regime federado tem como atributo permitir o compartilhamento de ações públicas perante a sociedade e promover maior cooperação financeira entre os entes políticos internos. Neste sentido, Souza (1998, p. 5) atenta: "A existência de um sistema federal implica cooperação política e financeira entre o governo federal e as demais esferas da federação".

Retomando ao binômio federação-descentralização, na América Latina, a partir da década de 1980, segundo Espinosa (2012), teve início uma série de esforços e processos de descentralização, por parte dos governos centrais, em vários setores, em direção aos assuntos estaduais prioritários (saúde, educação, desenvolvimento rural e turismo). Tais medidas resultaram, para a região, em um exercício fundamental de descongestionamento do centro, de crescimento e maturidade dos governos estaduais e, em menor medida, nos governos municipais, com suas exceções.

A intensa descentralização na América latina foi motivada pelos questionamentos dos administrados relacionados à aguda centralização políticaadministrativa, econômica e cultural no poder central, e, às vezes, agravada onde houve prolongada permanência de governos militares, autoritários e patrimonialistas durante boa parte do século XX (ESPINOSA, 2012).

Têm-se ainda argumentos para o processo descentralizador referente ao desgaste de legitimidade do modelo desenvolvimentista-intervencionista empregado durante parte do século passado, que foi abalado pelas crises fiscais do final da década de 1970 e propagada para a década de 1980.

No caso brasileiro, data do ano de 1974 o início do longo processo de distensão do regime autoritário imposto após o golpe armado de 1964, que gradualmente - e a despeito da resistência de grupos militares - levaria a redemocratização do país. "[...] Sua conclusão só ocorre, efetivamente em 1989, quando se restabeleceu no país a eleição direta para presidente da República" (HERMANN, 2011, p. 73).

No plano econômico, o período 1974-1984 marca o auge e o esgotamento do modelo de crescimento vigente no País desde os anos de 1950, ou seja, do modelo de substituição de importações comandada pelo Estado (através de investimentos e créditos públicos) e fortemente apoiado no endividamento (HERMANN, 2011). 
Neste sentido, segundo Espinosa (2012, p. 117),

[...] redistribuir poder constitui um exercício estratégico, que permitiu um desenvolvimento mais integrado como consequência de uma maior participação das ordens ou níveis de governo e administração: centralfederal, estadual e municipal, inclusive da sociedade civil.

A descentralização, além dos questionamentos internos, teve também promotores e entusiastas em organismos internacionais, como, por exemplo, o Banco Mundial (BM), o Fundo Monetário Internacional (FMI) e o Banco Interamericano de Desenvolvimento (BIRD), que não somente recomendavam ações sobre o assunto, mas também apoiavam os governos que levassem a cabo as ações de descentralização (ESPINOSA, 2012).

A descentralização também teve um suporte teórico: a linha teórica convencionada de New Public Management (NPM) (ou a Nova Gestão Pública NGP), com a indução dos diversos níveis de governo para a descentralização na estrutura organizacional, em especial o fomento a participação de entidades privadas sem fins lucrativos nas soluções as demandas sociais, em substituição do fornecimento direto pelo Estado.

No Brasil, na referida linha teórica, como experiência, vale destacar o Plano Diretor da Reforma do Aparelho do Estado (PDRAE), onde, segundo BresserPereira e Spink (2006), o objetivo da Reforma da Gestão Pública de 1995 era contribuir para a formação, no Brasil, de um aparelho de Estado forte e eficiente, compreendido pelas seguintes dimensões:

a) Dimensão institucional-legal, voltada para a descentralização da estrutura organizacional do aparelho do Estado, com base na criação de novos formatos organizacionais, como, por exemplo, as agências executivas, regulatórias, e as organizações sociais;

b) Dimensão gestão, definida pela maior autonomia e a introdução de 03 (três) novas formas de responsabilização dos gestores, a saber: 1) administração por resultados; 2) competição administrada por excelência; e, 3) controle social - em substituição parcial dos regulamentos rígidos, da supervisão e da auditoria, que caracterizam a administração burocrática; e 
c) Dimensão cultural, de mudança de mentalidade, visando passar da desconfiança generalizada que caracteriza a administração burocrática para uma confiança maior, ainda que limitada, própria da administração gerencial.

Segundo Matias-Pereira (2008), o surgimento da NPM na Administração Pública brasileira teve como pano de fundo a crise fiscal, a persistência da cultura burocrática - mitigada por práticas patrimonialistas -, e o elevado déficit de desempenho, em quantidade e qualidade na prestação dos serviços públicos, cuja reforma administrativa derivada de tal diagnóstico teve como estratégia, em um primeiro momento, privatizar, descentralizar, desregulamentar, entre outras ações, e em um segundo momento, buscar pela estruturação da capacidade administrativa institucional.

Com base nas orientações da NPM, Kerbauy (2007) afirma que a análise do poder local hoje, em especial, dos Municípios do interior do País, passa pela discussão dos temas "federalismo", "descentralização" e democracia", como processos fundamentais para o entendimento da reforma do Estado no Brasil, que teve e tem na descentralização seu locus fundamental.

Os defensores da descentralização dos gastos alegam que, se os bens e os serviços públicos locais são fornecidos pelas esferas de governo que se encontram mais próximas dos beneficiários, a alocação de recursos públicos tende a ser mais democrartica, eficiente e com accountability.

Segundo Rosen e Gayer (2015), um governo centralizado tende a fornecer o mesmo nível de serviços públicos em todo o País, independentemente do fato de os gostos das pessoas serem diferentes; por outro lado, um governo descentralizado permite o governo local a obtenção e o processamento das informações dos gostos dos seus administrados, a um custo menor do que um governo centralizado; assim, um governo local tem uma maior proximidade com seus cidadãos, seja ele mais sensível às preferências destes últimos do que o governo central.

Para Fisher (1996); Teixeira (2000) e FJP (2006 apud CARNEIRO, 2010), o discurso localista contemporâneo encorpa 02 (duas) vertentes de argumento que revalorizam a esfera local a partir de sua proximidade com os cidadãos. A primeira enfatiza os aspectos de controle político, accountability e democratização da gestão pública, reafirmando o local como espaço privilegiado de experimentalismo e de inovação institucional. A segunda fundamenta-se na eficiência alocativa, 
sustentando que os governos locais apresentam melhores condições de atender as necessidades e demandas da população, através da adoção de soluções não padronizadas, capazes de refletir e incorporar especificidades daquilo que é objeto da intervenção pública.

Segundo Schwartzman (2014), a justificativa para a descentralização costuma ser a de que os governos centrais não possuem capacidade gerencial suficiente para administrar tais serviços e distribuí-los a todas as localidades; e que estes seriam mais bem administrados por governos locais, e que, além disso, estariam submetidos ao controle direto da população local.

No entanto, aquele autor atenta que o processo de descentralização obteve mais sucesso em regiões que possuem uma Administração Pública madura e rica, ao passo que em regiões menos desenvolvidas e com a Administração Pública local com baixo capital humano, as transferências podem ser desastrosas, com a má utilização dos recursos disponibilizados ou apropriados pelas elites locais, não chegando efetivamente àqueles que necessitam.

Espinosa (2012, p. 117.) também faz ressalvas ao processo de descentralização:

[...] os governos enxergaram a descentralização como uma válvula de escape e administração da crise, visto que, ao envolver mais atores políticos e sociais para atender funções e responsabilidades, logravam não só atenuar as crises, mas também socializar os problemas e proceder de maneira conjunta sua solução, com isto, que a responsabilidade recaísse apenas sobre os governos centrais ou federais.

\subsection{Repartição de competências constitucionais em relação ao gasto}

O estabelecimento de atribuições específicas, em relação à provisão de bens ou serviços públicos, e a repartição de rendas são algumas características do regime federativo. O primeiro permite uma delimitação de funções de Estado e de governo na busca pela eficiência nas ações públicas, por meio da atenuação de possíveis conflitos de competências e de desperdícios de esforços e recursos entre os Estados-membros. O segundo, dar o suporte financeiro para que estes desempenhem suas funções.

Pierson (1995, p. 451 apud ABRUCIO; SANO, 2013, p. 219-20) observou que os sistemas federativos "sobrepõe a questão do 'quem deve fazer isto? sobre a 
tradicional pergunta 'o que deve ser feito'. Tal situação decorre da atuação de diferentes níveis de governo sobre um mesmo espaço territorial, de modo que a ausência de uma delimitação clara levaria à fragmentação das políticas sociais, acarretando em 02 (duas) possíveis situações, a saber: 1) a ausência de ações governamentais; ou, 2) a sobreposição das iniciativas de diferentes níveis de governo em um mesmo tema.

No que tange às repartições de competências, como forma de se evitar a duplicação de esforços na formatação e implementação de ações públicas pelas entidades federadas, as quais têm autonomia política-administrativa e suas ações incidem sobre um mesmo território e pessoas, tem-se a necessidade de se atribuir matérias específicas, concorrentes ou compartilhadas.

Assim, a repartição "competências" configura-se como um instrumental para esse fim. No caso do Brasil, com a presença de 03 (três) entidades políticas (União, Estados, Distrito Federal e Municípios), abrangidas por autonomia políticaadministrativa, coube à Carta Magna de 1988 tal repartição.

De fato, a CF de 1988 prevê as competências privativas da União (arts. 21 e 22) e dos Municípios (art. 30, inc. I), competências comuns da União, dos Estados, do Distrito Federal e dos Municípios (art. 23), competências concorrentes da União, dos Estados e do Distrito Federal (art. 24), e competências suplementares dos Municípios (art. 30, inc. II).

Para Aretche (2013, p. 77-78), a despeito da repartição das competências constitucionais entre União, Estados, Distrito Federal e Municípios, os "constituintes preservaram ampla autoridade para as iniciativas legislativas da União". Para aquela autora, o art. 21 lista as competências legislativas da União, mas tanto a União quanto as unidades constituintes podem iniciar a legislação, sendo que as normas da primeira prevalecem sobre as últimas. $O$ referido artigo possui 25 incisos e inclui algumas políticas executadas pelos governos subnacionais. Como exemplo, tem-se o poder de legislar sobre o desenvolvimento urbano, incluindo as questões de habitação, saneamento e transportes urbanos, mas cuja execução é realizada de forma descentralizada.

Ainda conforme Aretche (2013), o art. 22 lista as áreas de competência legislativa exclusivas da União, onde as unidades constituintes estão interditadas a legislar. Este artigo possui 29 incisos que tratam das leis e diretrizes básicas da 
educação, ainda que a execução dessa política, em nível infantil, fundamental e médio, seja concretizada por Estados e Municípios.

Aretche (2013) destaca que as competências privativas e legislativas da União somam 54 incisos, atribuindo, assim, o direcionamento de grande parte das competências para elaborar políticas a União, porém, as execuções de tais recaem sobre Estados e Municípios.

De outro modo, conforme descrito por Souza (2004), tem-se no Quadro 2, a seguir, uma série de competências comuns entre os 03 (três) níveis de governo, que permite um compartilhamento de esforços de gestão e financeiros para a consecução dos objetivos de cada Política Pública.

Quadro 2 - Competências concorrentes e competências municipais.

\begin{tabular}{|c|c|}
\hline Esfera de Governo & Serviços/Atividades \\
\hline $\begin{array}{l}\text { Federal-estadual-local (competências } \\
\text { partilhadas) }\end{array}$ & $\begin{array}{l}\text { Saúde e assistência pública; } \\
\text { Assistência aos portadores de deficiência; } \\
\text { Preservação do patrimônio histórico, artístico e } \\
\text { cultural; } \\
\text { Proteção do meio ambiente e dos recursos } \\
\text { naturais } \\
\text { Cultura, educação e ciência; } \\
\text { Preservação das florestas, da fauna e da flora; } \\
\text { Agricultura e abastecimento alimentar; } \\
\text { Habitação e saneamento; } \\
\text { Combate à pobreza e aos fatores de } \\
\text { marginalização social; } \\
\text { Exploração das atividades hídricas e minerais; } \\
\text { Segurança do trânsito; } \\
\text { Políticas para pequenas empresas; e } \\
\text { Turismo e lazer. }\end{array}$ \\
\hline Predominantemente local & $\begin{array}{l}\text { Pré-escola e educação fundamental; } \\
\text { Saúde; e } \\
\text { Preservação histórica e cultural. }\end{array}$ \\
\hline Apenas local & $\begin{array}{l}\text { Transporte coletivo; e } \\
\text { Uso do solo. }\end{array}$ \\
\hline
\end{tabular}

Fonte: Souza (2004)

A União, os Estados, o Distrito Federal e os Municípios, devido à repartição de competências quanto a Políticas Públicas estabelecidas pela CF de 1988, 
possuem atribuições que permitem a soma de esforços para o atendimento das demandas da sociedade.

O compartilhamento de competências sobre Políticas Públicas entre os entes federados autônomos exigem um poder de planejamento e coordenação para que as ações públicas possam ser realizadas, sem o desperdício de recursos e duplicação de esforços nas decisões de investimentos em uma mesma área geográfica.

\subsection{Relações interorganizacionais no processo de implementação das políticas públicas financiadas pelas transferências voluntárias da União}

Com a tendência de descentralização na Administração Pública que se verificou nas últimas décadas, criou-se um desafio para os países organizados em regimes federativos. Os governos subnacionais receberam maiores atribuições e passaram a ser responsáveis pela aplicação de maior volume de recursos na provisão dos serviços públicos e implementação das Políticas Públicas (BAIÃO, 2013).

Conforme apontado por Blöchliger e King (2006), em estudo relacionado à autonomia fiscal dos entes subnacionais dos países da OCDE, no período 19952004 foi possível observar o aumento da despesa recaída sobre as entidades estaduais (saúde e ensino, por exemplo) na Itália, no México e na Espanha, ou políticas ativas de emprego no Canadá. Nos Estados Unidos da América (EUA), os Estados assumiram plena responsabilidade por uma série de programas que antes eram suportados pelo poder central.

A contraparte, segundo aqueles atores, para que o suporte financeiro pudesse atender a tendência de descentralização, as entidades subnacionais das competências relacionadas ao atendimento das demandas sociais passaram a adotar mecanismos de repasses de recursos pelo poder central, por meio de transferências intergovernamentais, com extensão ao setor privado prestador de serviços públicos.

No caso brasileiro, uma parte da provisão e implementação de Políticas Públicas foram direcionadas para as municipalidades, por meio da descentralização de competências ou mediante indução por meio dos acordos de transferências voluntárias da União. 
Em relação à indução do poder central para a atribuição de competências para os níveis inferiores de gestão, Arrechte (1999, p. 119) observa que:

Em um Estado Federativo, caracterizado pela efetiva autonomia política dos diversos níveis subnacionais de governo, assunção de atribuições em qualquer área de políticas públicas - na ausência de imposições constitucionais - está diretamente associada à estrutura de incentivos oferecida pelo nível de governo interessado na transferência de atribuições.

Segundo Souza (1998), as transferências voluntárias podem ser destinadas ao encorajamento dos níveis subnacionais, a fim de adotarem determinadas políticas ou implementarem certos serviços considerados prioridade nacional.

Neste sentido, Moutinho e Kniess (2015, p. 2) asseveram:

O processo de transferências voluntárias de recursos entre as esferas da federação é uma importante ferramenta para viabilizar a melhor atuação dos entes federativos e pode ser vista sob duas óticas. A primeira é a de que recebe o recurso, caracterizando-se como sendo a possibilidade de materializar políticas públicas pontuais, beneficiando a população local. A segunda consiste na expectativa de que a aplicação dos recursos seja mais eficaz por parte da esfera convenente, pelo fato de estar mais próximo a população beneficiada do que se fosse diretamente aplicado pela esfera superior.

Para as entidades recebedoras, os repasses de recursos negociados com a União é uma alternativa para que enfrentem a problemática da escassez de recursos financeiros, com o fito de atingir os objetivos das Políticas Públicas propostas à sociedade. Já a União espera por um maior desempenho quanto à alocação desses recursos, em contraponto ao nível que seria atingido por uma execução direta, por meio dos órgãos federais e, assim, atender as demandas da população quanto à prestação dos serviços públicos, prezando pela maior eficiência, eficácia, efetividade e economicidade.

No entanto, para Abrucio (1998 apud SCHWARTZMAN (2014, p. 12):

O sucesso das políticas públicas dependem da relação que se estabelece entre os governos nacionais, estaduais, provinciais e locais em que se dividem os países do ponto de vista político-administrativo. O pressuposto dos estados federais é que os governos locais ao conterem recursos financeiros e humanos necessários para atender as necessidades locais, os governos centrais se encarregariam das questões de interesse regional, nacional e internacional. 
O mecanismo de transferências voluntárias vem se tornando um importante canal de distribuição dos recursos arrecadados pela União aos diversos entes subnacionais e entidades privadas sem finalidades lucrativas, no intuito de que estes últimos executem, de forma descentralizada, os objetivos das políticas públicas definidas nas leis orçamentárias anuais do OGU.

Tais acordos são classificados em implementação de Políticas Públicas em rede. Sobre a questão, Inojosa (1998 apud MALMEGRIN, 2012, p. 1-2) destaca:

\footnotetext{
Rede é parceria voluntária para a realização de um propósito comum. Implica, nesse sentido, a existência de entes autônomos que, movidos por uma ideia abraçada coletivamente, livremente e mantendo a própria identidade, articulam-se para realizar objetivos comuns.
}

A parceria, em termos pragmáticos, é considerada um processo de negociação e definição de objetivos comum com implicações nas respectivas tarefas (MATIAS-PEREIRA, 2008), ou seja, parcerias intergovernamentais (no caso de acordos entre os órgãos públicos das administrações federais, estaduais, municipais e Distrital) para o fornecimento de projetos e atividades presentes nas peças orçamentárias de ambos os partícipes configuram-se em duplo interesse de execução de determinada política pública.

Rezende (1997 apud MOUTINHO; KNIESS, 2015, p. 3) observa a dinâmica impressa no novo modelo de descentralização para execução dos gastos públicos, notadamente a partir do advento da CF de 1988, fundamentado na parceria entre as esferas de poder.

Diante disso, conforme abordado no tópico: 2.4 Repartição de competências constitucionais em relação ao gasto, com a Carta de 1988 houve uma intenção dos constituintes em descentralizar a responsabilidade do gasto em determinadas políticas públicas as localidades, a exemplo das prestações de serviços relacionados à saúde, educação, transporte etc.

Como ferramentas intergovernamentais, as parceiras geralmente envolvem o estabelecimento de prioridades, o fornecimento de incentivos nos níveis mais altos do governo e a permissão de que outros ajam para alcançá-las (...). Significando 
maior utilização de parceiras público-público ou público-privada (RADIN, 2010, p. $607)$.

Segundo Matias-Pereira (2008), a atuação em redes e parcerias estratégicas tem derivação no setor privado, tendo como arcabouço teórico a Teoria das Alianças Estratégicas e Parceiras que é utilizada no campo da administração, na qual as empresas percebem que existe apenas uma forma de sobrevivência num mundo altamente competitivo e globalizado: a união e soma de esforços.

Aliança estratégica, num sentido amplo, orientada para o setor público pode ser definida como o resultado de uma associação ente duas ou mais instituições, organismos ou empresas públicas, ou entre o setor público ou privado, que juntam recursos e know-how para implementar uma atividade específica, criar sinergias de grupos ou como opção estratégica de fortalecer suas competências. A associação, nesse caso, pode ser feita para atender as demandas da sociedade por bens e serviços em áreas sensíveis, como saúde, educação, alimentação, ciência e tecnologia, segurança, transferências de tecnologias, entre outras, bem como adquirir novas competências ou ganhar dimensão critica (MATIAS-PEREIRA, 2009).

Segundo a formulação de Matias-Pereira, os Quadros 4 e 5 apresentam as principais características, objetivos e dimensões das parcerias estratégicas flexíveis.

Quadro 3 - Características e objetivos das parcerias estratégicas flexíveis.

\begin{tabular}{|l|l|}
\hline \multicolumn{1}{|c|}{ Característica } & \multicolumn{1}{c|}{ Objetivo } \\
\hline $\begin{array}{l}\text { Deve ser entendido como um compromisso a } \\
\text { longo prazo; uma relação baseada em } \\
\text { participação e compartilhamento de } \\
\text { capacidades, recursos, bens; uma relação } \\
\text { recíproca com uma estratégia compartilhada } \\
\text { como ponto comum; cada integrante preserva } \\
\text { sua identidade, autonomia e valores; a intenção } \\
\text { permanente de compartilhar e avançar as } \\
\text { possibilidades de cada integrante envolvido na } \\
\text { parceria }\end{array}$ & $\begin{array}{l}\text { Compartilhar riscos; compartilhar sucesso; obter } \\
\text { economia de escala; acessar novas frentes de } \\
\text { atuação; acessar tecnologia e conhecimento; } \\
\text { ampliar sua capilaridade (ampliar atuação } \\
\text { geográfica); resolver limitações financeiras; } \\
\text { alavancar habilidades (quando uma organização } \\
\text { precisar do conhecimento específico que outra } \\
\text { organização detém). }\end{array}$ \\
\hline
\end{tabular}

Fonte: Matias-Pereira (2008). 
Quadro 4 - Dimensões estratégias de parceria.

\begin{tabular}{|c|c|}
\hline Dimensão & Descrição \\
\hline Mentalidade da cooperação & $\begin{array}{l}\text { Refere-se à potencialidade contida na postura e atitude dos } \\
\text { atores do processo no que tange aos relacionamentos } \\
\text { interpessoais. Segundo Austin (2001), essa dimensão e a } \\
\text { mais "sensível", pois são as pessoas que constroem, mantêm } \\
\text { e possibilita avanço, o retardo e até o fracasso de uma } \\
\text { parceria. }\end{array}$ \\
\hline Alinhamento estratégico & $\begin{array}{l}\text { Abrange o grau de compatibilidade das definições de valores } \\
\text { estratégicos assumidos pelas organizações ao interagir na } \\
\text { rede cooperativa, por exemplo, princípios norteadores, } \\
\text { diretrizes gerais e outros elementos que comunicam o perfil } \\
\text { de atuação do parceiro no ambiente. Essa dimensão trata do } \\
\text { estabelecimento de uma base solida nos aspectos essenciais } \\
\text { de organização da parceria. Assim, a adequada afinidade } \\
\text { entre os parceiros nas questões estratégicas constitui o } \\
\text { alicerce fundamental para o funcionamento seguro do } \\
\text { processo cooperativo. }\end{array}$ \\
\hline Valor da Cooperação & $\begin{array}{l}\text { Como podem ser avaliados os esforços de cada parceiro, } \\
\text { mobilizados no sentido de maximizar as competências para } \\
\text { agregar valor ao conjunto de participantes da parceira? O } \\
\text { senso da importância vital da atuação sinérgica é um fator } \\
\text { determinante para obter resultados significativos e, } \\
\text { consequentemente, para alcançar objetivos melhores entre } \\
\text { os parceiros. }\end{array}$ \\
\hline Administração do relacionamento & $\begin{array}{l}\text { Envolvem os aspectos ligados às responsabilidades do } \\
\text { gerenciamento da parceria que incluem o acompanhamento } \\
\text { da comunicação, desempenho, motivação etc. trata-se, } \\
\text { portanto, da gestão do processo da ação compartilhada, que } \\
\text { exige o acompanhamento dos fluxos das atividades } \\
\text { definidos, a manutenção dos mecanismos de ação e } \\
\text { motivação das equipes para o incremento dos resultados, } \\
\text { ampliados pela força sinérgica dos esforços unificados e } \\
\text { coordenados dos parceiros. }\end{array}$ \\
\hline
\end{tabular}

Fonte: Austin (2001 apud MATIAS-PEREIRA, 2008, p. 34).

Há também um forte laço entre as Parcerias intergovernamentais e os arranjos institucionais. Segundo Gomide e Pires (2014, p. 19), arranjo institucional é entendido como o conjunto de regras, mecanismos e processo que definem a forma particular como se coordenam atores e interesses na implementação de uma política pública específica. (...) Em torno de cada política se arranjam organizações (com seus mandatos, recursos, competências e instrumentos legais), mecanismos de coordenação, espaços de negociação e decisão entre atores (do governo, do sistema político e da sociedade), além das obrigações de transparência, prestação de contas e controle. 
Importante ressaltar o estabelecimento de relações interoganizacionais no setor público, segundo Radin (2010, p. 601), coincidiram no tempo com o desenvolvimento do que foi chamado de movimento da New Public Management NPM.

Para Radin (2010, p. 599), o desenvolvimento inicial da gestão intergovernamental representou o reconhecimento de que muitas políticas e programas requeriam atividades que ultrapassassem um único nível de governo ou uma única jurisdição, levando a abordagens alternativas da autoridade governamental autônoma e separada, dessa forma números maiores e políticas exibiram características de interdependência entre os níveis de governos, significando que múltiplos níveis estão simultaneamente envolvidos em programas e politicas e que um nível isolado raramente tem poder único e influencia sobre o modo como os programas são projetados, financiados, administrados e fornecidos.

Para Xun (2014, p, 17) a NPM foi uma abordagem que muitas vezes teve como objetivo separar mais claramento os órgãos criadores de políticas públicas dos órgãos implementadores, a fim de impulsionar a eficiência e a eficácia administrativa.

Segundo Xun (2014, p. 106) os atores de nível central - em muitos cenários, provavelmente coordenadores - precisaram cumpri funções altamente importantes: direcionamento da tomada de decisão, acompanhamento da implementação, estabelecimento e aplicação de padrões mínimos e prestação de assistência técnica e capacitação onde as capacidades locais variam muito.

Entretanto, de acordo Gomide e Pires (2014, p. 16), apesar da Constituição de 1988 instituir uma série de mecanismos para o envolvimento dos atores sociais, políticos e econômicos no processo de formulação e gestão das políticas públicas, ao ampliar os instrumentos de controle, participação e transferências das decisões públicas. Isto, por sua vez, tomou mais complexo o ambiente institucional para a formulação, coordenação e execução de políticas públicas no Brasil.

Conforme citações de Abrucio e Sano (2013, p. 217), no artigo "Cooperação intergovernamental e políticas públicas no Federalismo Brasileiro", cada um dos entes representa locais autônomos de autoridade política com capacidade não somente para formular politicas próprias, mas também para influenciar políticas que surgem do centro e participar delas, em alguma medida (Pierson, 1995). A coexistência de diferentes instâncias de poder molda "formas peculiares de relações 
intergovernamentais, 'constitutivamente competitivas e cooperativas', e necessariamente caracterizadas pelo conflito de poder, como pela negociação entre as esferas de governo" (Almeida, 2001:14, destaque no original).

Dessa forma, nas relações interorganizacionais é possível a ocorrência do problema abordado na Teoria Agente Vs Principal. Segundo essa Teoria, os conflitos de agência aparecem quanto o bem-estar de uma parte, denominado Proprietário ou Principal, depende das decisões tomadas por outra, responsável pela gestão do seu patrimônio, denominado Agente. Embora o agente deva tomar decisões em benefício do Principal, muitas vezes ocorrem situações em que os interesses dos dois são conflitantes, dando margem a um comportamento oportunista por parte do Agente.

Sendo assim, as relações interorganizacionais são passíveis de um conflito de interesses entre os agentes envolvidos, ou melhor, um trade-off entre o órgão da União repassador dos recursos e os órgãos dos entes subnacionais que os recebem, que podem ocasionar no atraso das execuções das políticas públicas caracterizadas de interesses mútuos ou mesmo na execução parcial ou inexecução total do objeto conveniado

O problema contemplado por essa Teoria está relacionado à existência de informação assimétrica entre agente e principal, visto que o custo do controle total para o principal é tão elevado que não compensaria contratar o agente. No entanto, o agente, com único que detém todas as informações sobre seu próprio desempenho, pode utilizá-la de forma oportunista. (MATIAS-PEREIRA, 2008, p. 137).

Segundo Matias-Pereira (2008, p. 137) a Teoria Agente-Principal assume ainda mais relevância na discussão sobre descentralização, tanto nas questões referentes ao federalismo (ou seja, envolvido as esferas de poderes subnacionais) quanto na descentralização intra-organizacional em agencias e setores de governo.

Nessa relação entre órgãos federais e órgãos das outras esferas administrativas ou da sociedade civil organizada, podemos classificar aqueles em Principal e estes como Agentes. Os órgãos da União ao fazerem a transferências de recursos financeiros para a implementação das políticas públicas por parte dos órgãos e entidades de outra esfera administrativa, acabam por ter nessa interação um possível conflito de interesses e informações assimétricas que acabam por afetar 
o desenvolvimento das políticas públicas pactuadas por meio de convênios e congêneres.

Levando em conta que repasses financeiros da União, de forma individualizada, em sua grande parte, podem envolver pequenos valores. Dessa forma, acaba por induzir na pouca atenção dos gestores dos órgãos estaduais ou municipais que recebem os recursos.

Ainda, a proposição de parcerias pelos entes subnacionais, no primeiro momento, são de interesses dos gestores ou agentes políticos, a exemplo das emendas parlamentares. No entanto, em um segundo momento, apesar da restrição orçamentária imposta, os gestores têm a preferência em utilizar os recursos próprios em detrimento aos repasses voluntários da União.

Segundo Rezende (2011, p. 342), em relação a esse fato, quanto menor for à contribuição direta dos repasses para o orçamento estadual e municipal, maior será, portanto, o risco de ineficiência e desperdícios na utilização desses recursos.

Sendo assim, a União ao "pulverizar" os recursos financeiros a uma gama de acordos para as entidades interessadas na execução de determinadas políticas públicas, na verdade pode estar induzindo ao pífio desempenho de execução de tais recursos.

Nesse sentido, a legislação sobre transferências voluntárias busca reduzir os conflitos de agência entre os participes do setor público subnacional, na forma da comprovação da previsão orçamentária e participação financeira nos projetos de execução de objetivos mútua de políticas públicas.

Em que pese o que dispõe $\mathrm{o}$ art. 24, da Portaria Interministerial $\mathrm{n} \cong 507 / 2011$, a qual explicita que a contrapartida é uma faculdade não obrigação ao convenente. As Leis de Diretrizes Orçamentária (LDO) da União vem regulando as obrigatoriedades para os entes subnacionais ao manifestarem a vontade de realizar acordos com a União para o recebimento desses recursos tenham previsão orçamentária no exercício e participem com um quantum determinado pela própria LDO do exercício9.

\footnotetext{
9 Segundo a LDO da União (Vigente), Lei n 13.242, de 30 de dezembro de 2015, estabelece, em seu art. 77 e $\S 1^{\circ}$, que a realização de transferências voluntária s, conforme definidas no caput do art. 25 da Lei de Responsabilidade Fiscal, dependerá da comprovação, por parte do convenente, de que existe previsão de contrapartida na lei orçamentária do Estado, Distrito Federal ou Município. § 1 o A contrapartida, exclusivamente financeira, será estabelecida em termos percentuais do valor previsto no instrumento de transferência voluntária.
} 
Diante dessa previsão na LDO, temos uma tentativa de reduzir a proposição de projetos e atividades que não guardem sinergia entre as entidades públicas envolvidas.

No entanto, monitorar o comportamento dos diversos órgãos das administrações direta e indireta dos 26 estados, dos 5.570 municípios e do Distrito Federal, além de inúmeras entidades privadas sem fins lucrativos tem um alto custo para a União e uma alta assimetria da informação em referência aos acordos firmados.

Como forma dos órgãos da União (Principal) poder minorar a assimétrica da informação, e, dessa forma, monitorar a execução das políticas públicas a cargos dos entes subnacionais e entidades privadas sem fins lucrativos, o Ministério do Planejamento, Orçamento e Gestão (MP) desenvolveu ${ }^{10}$ (em conjunto com outros órgãos federais) e implantou no ano de $2007^{11}$ um sistema para gerir os recursos do orçamento fiscal e da seguridade social da União.

O denominado de Sistema de Gestão de Convênios e Contratos de Repasses - SICONV tem o objetivo de sistematizar procedimentos, que possibilitem a redução dos esforços para publicidade, celebração, acompanhamento e prestação de contas. Bem como, o efetivo controle institucional e social sobre os convênios, contratos de repasse e termos de parceria, conforme intenções listadas abaixo:

- Imprimir mais eficiência, agilidade e transparência ao processo de liberação de recursos para Estados, Distrito Federal, Municípios, consórcios públicos e entidades privadas sem fins lucrativos;

- Possibilitar efetivo controle sobre a aplicação dos recursos públicos, tanto por parte dos órgãos de fiscalização e controle (TCU, CGU, MPF, Congresso Nacional), quanto por parte dos ministérios e da sociedade civil;

- Reforçar o pacto federativo instituído pela Constituição Federal;

- Aprimorar a relação entre Governo Federal e organizações da sociedade civil;

- Desburocratizar o processo de transferências voluntárias;

- Padronizar os procedimentos; e

- Eliminar as fragilidades dos processos e garantir ao Governo Federal o efetivo controle sobre as transferências voluntárias da União.

\footnotetext{
${ }^{10} \mathrm{Em}$ atendimento as recomendações e imposições do Tribunal de Contas da União (TCU). Para detalhes sugerimos as leituras dos Acórdãos TCU № 788/2006 e ํㅜ․ 2.066/2006.

11 Decreto no 6.170, de 25 de julho de 2007.
} 
No sistema SICONV, realiza-se os registros das celebrações de acordos de transferências voluntárias da União para a administração pública direta e indireta dos estados, municípios, Distrito Federal, assim como para as entidades filantrópicas, das liberações de recursos, do acompanhamento da execução e prestação de contas de convênios e congêneres. Sendo um Sistema aberto ao público, via web, acessível por meio de página específica denominada de Portal dos Convênios, com endereço de acesso eletrônico: (www.convenios.gov.br)

\subsection{O processo de planejamento orçamentário, gestão e controle das políticas públicas financiadas por transferências voluntárias da União}

Diante do exposto até este ponto, observamos o alto grau de complexidade envolvendo a interação entre diferentes entidades, com sua estrutura administrativa, representada pelos seus órgãos, cada qual com seus objetivos e interesses não raras vezes conflitantes.

Não diferente seria a acomodação de tantos fatores relacionados a autonomia e interdependência no processo de formulação e implementação de políticas públicas.

Sendo assim, esta parte do trabalho tem como função identificar pontos de contatos no processo planejamento sobre os repasses de recursos de transferências voluntárias da União.

\subsubsection{Planejamento orçamentário}

O sistema de planejamento e orçamento no Brasil é representado por três instrumentos integrados, de iniciativa legislativa do poder Executivo da União, dos Estados, dos Municípios e do Distrito Federal, por meio do qual se estabelece as diretrizes e são alocados os recursos públicos.

Conforme estabelecido no art. 165 da Constituição de 1988, esses instrumentos são representados pelo Plano Plurianual (PPA), Lei de Diretrizes Orçamentárias (LDO), e Lei Orçamentária Anual (LOA). 


\subsubsection{Plano Plurianual}

O Plano Plurianual (PPA) previsto na Constituição Federal, nas Constituições Estaduais e nas Leis Orgânicas do Distrito Federal e dos Municípios é o instrumento legal de planejamento de maior alcance temporal no estabelecimento das prioridades e no direcionamento das ações do governo. Estabelece para a administração pública, em geral de forma regionalizada (definido na legislação de cada ente), as diretrizes, objetivos e metas que orientarão a aplicação dos recursos, que podem ser públicos ou privados, neste caso quando decorrente de parcerias, para um período equivalente ao do mandato do (a) chefe do Poder Executivo, deslocado em um exercício financeiro (atualmente, quatro anos) (ALBUQUERQUE et al. 2013, p. 25).

Quanto a esse último aspecto, em vista da continuidade das ações estatais há um deslocamento temporal na vigência do PPA, tornando-o não estritamente coincidente como o mandato do chefe do poder executivo. Ou seja, o governo sucessor irá executar o último ano de vigência do PPA do sucedido, e assim sucessivamente, até que lei específica determine outra forma.

O quadro 6 apresenta essa atemporalidade do PPA, quanto a mandado do chefe do poder executivo das três esferas de poder.

Quadro 5 - Deslocamento em um exercício do Plano Plurianual em relação ao mandato presidencial.

\begin{tabular}{|c|c|c|c|c|c|c|c|c|}
\hline Ano $X$ & Ano $X+1$ & Ano $X+2$ & Ano $X+3$ & Ano $X+4$ & Ano $X+5$ & Ano $X+6$ & Ano $X+7$ & Ano $X+8$ \\
\hline \multicolumn{4}{|c|}{ Mandato Presidencial 1} & \multicolumn{4}{|c|}{ Mandato Presidencial 2} & \\
\hline & \multicolumn{4}{|c|}{ PPA $(X+1$ a $X+4)$} & \multicolumn{4}{|c|}{ PPA $(X+5 a X+8)$} \\
\hline
\end{tabular}

Fonte: Albuquerque et al. (2013).

No que se refere a prazos para a apreciação do Projeto de Lei do PPA, a Constituição em seu art. $165, \S^{\circ}$ reporta a instituição de lei complementar para a instituição de regras e prazos para a tramitação do Projeto. No entanto, esse dispositivo legal ainda não compõe a arcabouço normativo. Diante da falta dessa norma, vigora o estabelecido no Ato das Disposições Constitucionais Transitórias (ADCT), em que o Projeto de PPA deverá ser encaminhado pelo poder executivo ao $\mathrm{CN}$ até quatro meses antes do encerramento do exercício, e por este devolvido para 
sanção do chefe do executivo até o encerramento da sessão legislativa -15 de dezembro.

O PPA apresenta-se, segundo Castro (2012, p. 380), "como um instrumento de planejamento das ações de governo e a condução política-orçamentária, e também como um instrumento de gestão, na medida em que possibilita a definição de prioridades atuais com uma visão de futuro. (...) Nesse plano de médio prazo, devem constar os detalhamentos das políticas públicas a serem executadas, tais como metas físicas e financeiras, público-alvo, parcerias, produtos a serem entregues, dentre outras".

Sendo assim, por meio desse Plano de médio prazo os governos demonstram a sociedade o direcionamento das ações, quanto políticas públicas, para dar soluções ou ofertar serviços a problemas ou demandas da sociedade, assim como permite a participação dos próprios destinatários das políticas públicas na elaboração desse instrumento de planejamento.

$\mathrm{Na}$ elaboração do PPA 2012-15, da União, conforme apontado por Albuquerque et al (2013, p. 444), tiveram como princípios:

- A Participação social como importante instrumento de interação entre o Estado e o Cidadão, com vistas à efetividade das políticas públicas;

- Incorporação da dimensão territorial na orientação da alocação dos investimentos;

- Aperfeiçoamento das diretrizes para uma alocação orçamentária mais eficiente na priorização dos investimentos;

- Foco na efetividade, entendida como desempenho quanto à transformação de uma realidade, que aponta mudanças socioeconômicas, ambientais ou institucionais necessárias e que deverão ocorrer nas políticas públicas; e

- Estabelecimento de parcerias com os Estados, os Municípios, a iniciativa privada e a sociedade civil, visando à união de esforços para o alcance de objetivos comuns.

Segundo Albuquerque (2013, p. 444) "A participação social na elaboração e gestão do PPA representa um importante instrumento de interação entre o governo e o cidadão para o aperfeiçoamento das políticas públicas". 
Essa possibilidade de participação no planejamento governamental da União é algo recente, inaugurado a experiência com a elaboração do PPA 2004-07 em que contou com a participação de 2.000 organizações nos fóruns realizados nos 26 estados e no Distrito Federal.

Com o PPA 2008-11 foi consolidado os canais formais de participação social no planejamento governamental, com a incorporação das ações do Conselho de Desenvolvimento Econômico e Social (CDES) ${ }^{12}$ no processo de construção do PPA.

$\mathrm{Na}$ construção do PPA 2012-15 a participação social no processo de planejamento governamental da União obteve uma maior abertura promovida pela primeira edição do Fórum Interconselhos, o qual contou com a participação de 300 representantes dentre conselheiros e comissões nacionais e entidades de diversos setores da sociedade, permitido que um maior público apresentasse recomendações e sugestões de políticas públicas.

$\mathrm{Na}$ estratégia de elaboração do PPA 2016-19 é dada a continuidade ao processo de participação e o amplia com o envolvimento direto dos Ministérios na captação das demandas das diversas entidades envolvidas, assim como ao prever a participação também na fase de acompanhamento da execução do plano.

A Figura 1 - Participação Social na Elaboração do PPA 2016-2019 ilustra a participação entre órgãos governamentais e desses com a sociedade civil, em relação à discussão para a elaboração do atual PPA.

12 O Conselho de Desenvolvimento Econômico e Social (CDES) foi criado pela Lei n. 10.683, de 28 de maio de 2003, que estabelece que "ao Conselho de Desenvolvimento Econômico e Social compete assessorar o Presidente da República na formulação de políticas e diretrizes específicas, e apreciar propostas de políticas públicas, de reformas estruturais e de desenvolvimento econômico e social que Ihe sejam submetidas pelo Presidente da República, com vistas na articulação das relações de governo com representantes da sociedade". Ver http://www.cdes.gov.br 


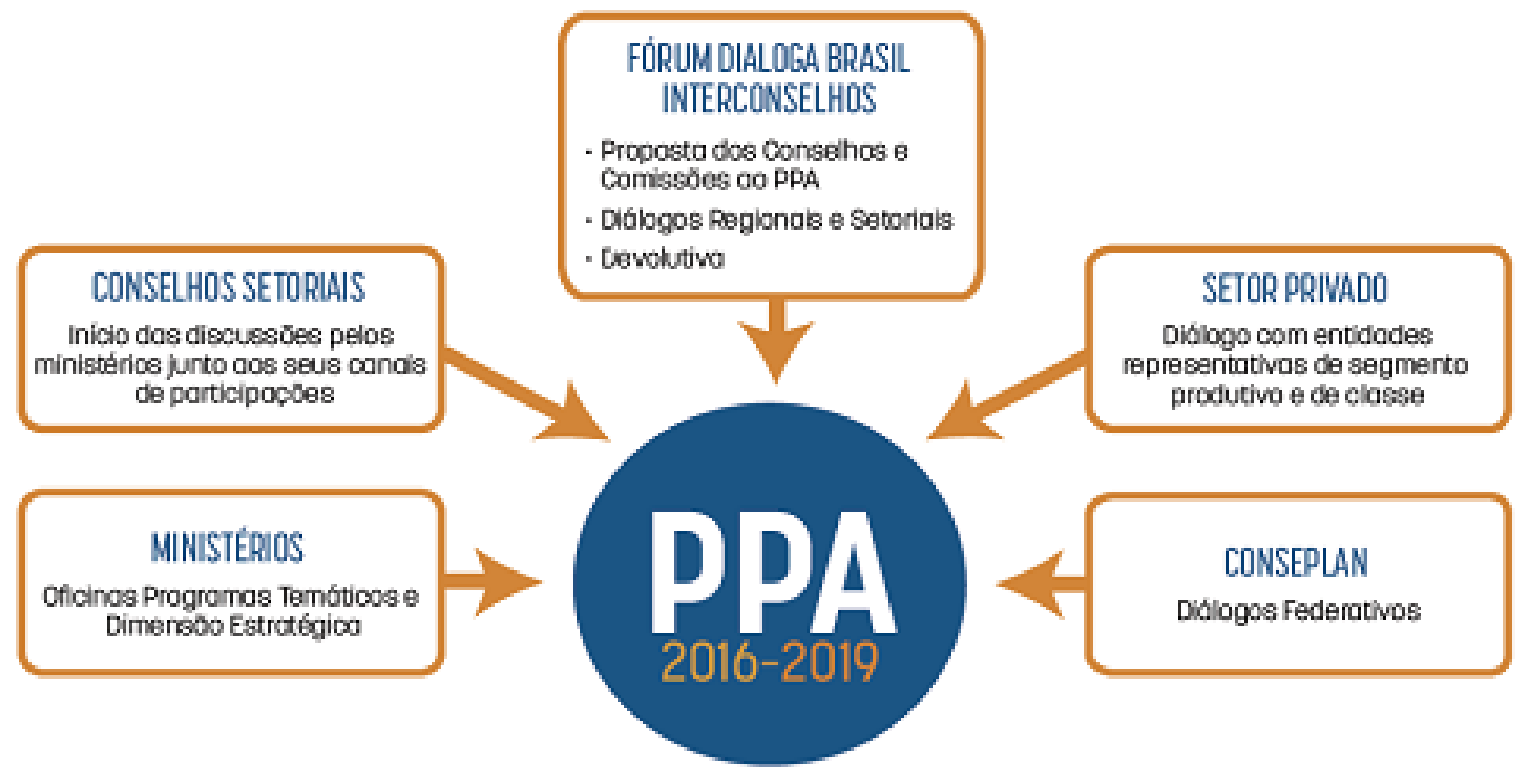

Figura 1 - Participação social na elaboração do Plano Plurianual 2016-2019.

Fonte: Mensagem Presidencial do PPA 2016-19

No entanto, segundo Albuquerque et al. (2013, p. 445) essas consultas à sociedade não possuem caráter deliberativo, mas sem dúvida tem o poder de influenciar o rumo das políticas públicas definidas pelo governo. Ao estimular um debate mais participativo, o Governo entende que a articulação entre os entes governamentais e a participação social representa um caminho para o aperfeiçoamento da gestão do PPA.

Mesmo com a limitação apontada por Albuquerque et al (2013), os canais para a participação estão cada vez mais presentes no processo de elaboração dos Planos Plurianuais da União.

Portanto, eles vêm se tornando um canal de discussão e inclusão de propostas para a deliberação para a sociedade e as entidades captadoras de recursos: órgãos públicos das diversas unidades federativas e organizações da sociedade civil. Dessa forma, cabe às entidades públicas ${ }^{13}$ e privadas dispostas a firmar parcerias com os órgãos da União, por meio das transferências voluntárias, participarem das elaborações dos Planos da União no intuito de alinharem seus planos, no intuito de formarem um planejamento comum de médio prazo com planos de ações factíveis de serem executados, em benefício às populações focais de cada uma das políticas executadas de forma descentralizada.

${ }^{13}$ Cada ente da federação tem seu próprio PPA, os quais nem sempre são coincidentes e seguem o disposto no Ato das Disposições Constitucionais Transitórias (ADCT), quanto a prazos. 
Essa função de propostas institucionais de políticas públicas para parcerias é tornada mais relevante no processo de planejamento da União em que, em relação último princípio apontado no PPA 2012-15 da União o qual traz a intencionalidade da União no "Estabelecimento de parcerias com os Estados, os Municípios, a iniciativa privada e a sociedade civil, visando à união de esforços para o alcance de objetivos comuns".

Apesar de não explicito no atual, podemos afirmar a permanência desse princípio. Na mensagem Presidencial afirma-se que não foram realizadas alterações significativas quanto à estrutura e conceitos. E ainda, reforça a participação social nas fases de planejamento, elaboração e implementação das políticas públicas a serem efetuadas durante a vigência do Plano. Fatos esses que trazem para o Plano a intencionalidade do Governo Federal em dar continuidade à interação intergovernamental e com as organizações privadas sem fins lucrativos.

No entanto, essa relação só trará efeitos caso os sistemas de planejamento dos parceiros públicos e privados estejam em consonância com o da União, no intuito de permitir maior e melhor discussão das políticas públicas a serem executadas, possibilitar um indicativo para os parceiros quanto à identificação dessas políticas para a elaboração de propostas consistentes e completas, com fim último de execução dessas políticas propostas a parceria de forma adequada.

Esse desafio esse recai com maior intensidade sobre as gestões públicas municipais, devido ao processo eleitoral não ser coincidente com o processo da União, Estados e Distrito Federal, no que se reflete na não coincidência temporal para a elaboração dos instrumentos de planejamento, uma defasagem de dois anos entre os instrumentos da União para com os instrumentos municipais.

A Figura 2 demonstra essa defasagem entre o processo eleitoral e de elaboração dos instrumentos de planejamento da União e Munícipios, no que impõe uma dificuldade para que haja uma coincidência de objetivos de políticas públicas entre tais entidades federadas. 

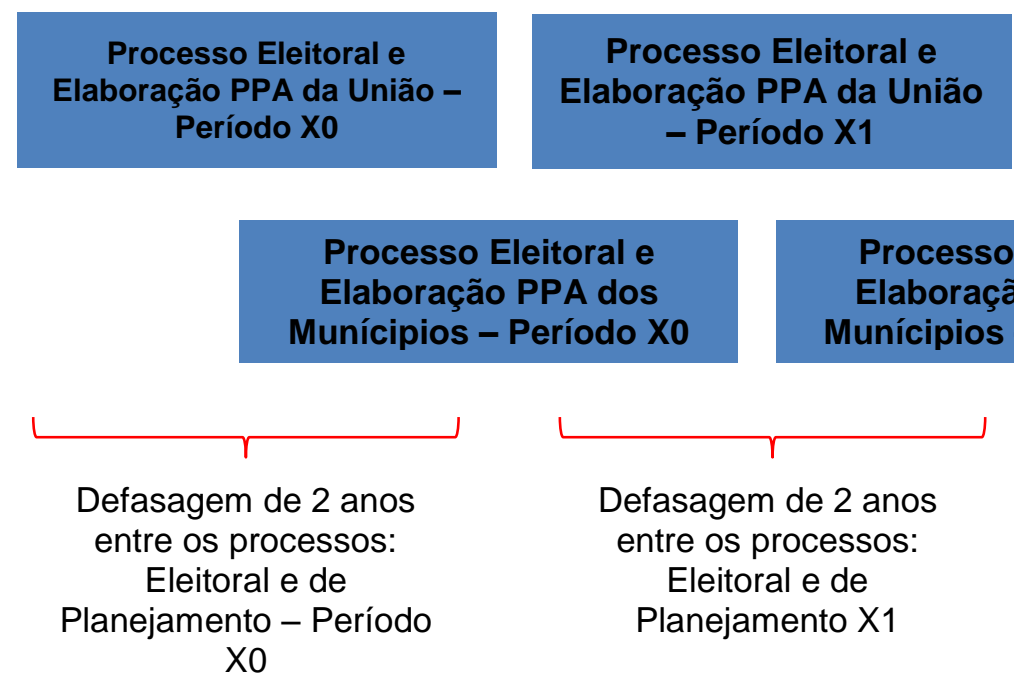

Processo Eleitoral e

Elaboração PPA dos

Munícipios - Período X1

planejamento da União e dos Municípios.

Fonte: Elaborado pelo autor.

A compatibilização temporal entre os instrumentos de planejamento da União e dos Municípios é fundamental para que haja a identificação de demandas coincidente, para a discussão de propostas de políticas públicas, e para a inclusão dessas nos instrumentos de planejamento. Dessa forma, permitirá que os partícipes tenham conhecimento prévio das ações a serem executadas e possibilite a elaboração e apreciação de projetos adequados de captação de recursos de transferências voluntárias e que sejam executados em tempo para que as demandas sociais sejam atendidas.

\subsubsection{A Lei de Diretrizes Orçamentárias}

A Lei de Diretrizes Orçamentárias - LDO é um instrumento de planejamento orçamentário que tem como função integrar o plano estratégico, representado pelo PPA, com o plano operacional, representado pela Lei orçamentária Anual. Conforme os termos do $\S 2^{0}$ do art. 165 da CF 88, esse instrumento de planejamento "compreenderá as metas e prioridades da administração pública federal, incluído as despesas de capital para o exercício financeiro subsequente, orientará a elaboração da lei orçamentária anual, disporá sobre alterações na legislação tributária e estabelecerá a política de aplicação das agências oficiais de fomento". 
Ressalta-se que além dessas competências definidas a nível constitucional, com a publicação da Lei de Responsabilidade Fiscal (LRF) ${ }^{14}$ a LDO passou a também dispor sobre outras questões relacionadas a finanças públicas, dentre as quais, condições e exigências para a transferências de recursos a entidades públicas e privadas, conforme apresentado no Quadro 6 ${ }^{15}$ :

${ }^{14}$ Lei Complementar $n^{\circ} 101 / 2000$.

${ }^{15}$ Com base na Lei $n^{\circ} 13.242$, de 30 de dezembro de 2015, Lei de Diretrizes Orçamentárias (LDO) para o exercício de 2016. 
Quadro 6 - Algumas exigências estabelecidas pela Lei de Diretrizes Orçamentárias em relação às transferências voluntárias.

\begin{tabular}{|c|c|}
\hline Entidades Públicas & Entidades Privadas sem Fins Lucrativos \\
\hline $\begin{array}{l}\text { Previsão de contrapartida na lei orçamentária do } \\
\text { Estado, Distrito Federal ou Município. }\end{array}$ & $\begin{array}{l}\text { Recursos direcionados para aquelas que } \\
\text { exerçam atividades de natureza continuada nas } \\
\text { páreas de assistência social, saúde ou } \\
\text { educação. }\end{array}$ \\
\hline $\begin{array}{l}\text { A contrapartida, exclusivamente financeira, será } \\
\text { estabelecida em termos percentuais do valor } \\
\text { previsto no instrumento de transferência } \\
\text { voluntária, considerando-se a capacidade } \\
\text { financeira da respectiva unidade beneficiada e } \\
\text { seu Índice de Desenvolvimento Humano (IDH), } \\
\text { variando de } 0,1 \% \text { a } 20 \% \text {. }\end{array}$ & $\begin{array}{l}\text { Sejam constituídas sob a forma de fundações } \\
\text { incumbidas regimental e estatutariamente para } \\
\text { atuarem na produção de fármacos, } \\
\text { medicamentos e insumos estratégicos na área } \\
\text { de saúde. }\end{array}$ \\
\hline $\begin{array}{l}\text { Documentação comprobatória da regularidade } \\
\text { ou, a critério do beneficiário, de extrato emitido } \\
\text { pelo Serviço Auxiliar de Informações para } \\
\text { Transferências Voluntárias (CAUC), refletindo } \\
\text { sobre: } \\
\text { - Regularidade quanto a pagamento de } \\
\text { tributos, empréstimos e financiamentos } \\
\text { devidos a ente transferidor; } \\
\text { - Prestação de contas de recursos } \\
\text { anteriormente recebidos; } \\
\text { - Cumprimento de limites constitucionais } \\
\text { quanto à Saúde e Educação; } \\
\text { - Observância a limites da dívida } \\
\text { consolidada, de operações de crédito, de } \\
\text { inscrições de restos a pagar e despesa } \\
\text { total com pessoal. }\end{array}$ & $\begin{array}{l}\text { Prestem atendimento direto ao público e tenham } \\
\text { certificação de entidade beneficente de } \\
\text { assistência social, nos termos da Lei n. } 12.101 \text {, } \\
\text { de } 27 \text { de novembro de } 2009 \text {. } \\
\text { A certificação de que trata o inc. II do art. } 00 \\
\text { poderá ser: } \\
\text { I - substituída pelo pedido de renovação da } \\
\text { certificação devidamente protocolizado e ainda } \\
\text { pendente de análise junto ao órgão competente, } \\
\text { nos termos da legislação vigente; } \\
\text { II - dispensada, para execução de ações, } \\
\text { programas ou serviços em parceria com a } \\
\text { Administração Pública Federal, nas seguintes } \\
\text { áreas: } \\
\text { a) Atenção à saúde dos povos indígenas; } \\
\text { b) Atenção às pessoas com transtornos } \\
\text { decorrentes do uso, abuso ou } \\
\text { dependência de substâncias psicoativas; } \\
\text { c) Combate à pobreza extrema; } \\
\text { d) Atendimento às pessoas com } \\
\text { deficiência; e } \\
\text { e) Prevenção, promoção e atenção às } \\
\text { pessoas com Human Immunodeficiency } \\
\text { Virus (HIV) }{ }^{16} \text {, hepatites virais, } \\
\text { tuberculose, hansenpiase, malária e } \\
\text { dengue; ou } \\
\text { III - dispensada, desde que a subvenção seja } \\
\text { concedida por lei específica e a entidade tenha } \\
\text { seu funcionamento autorizado e estatutos } \\
\text { homologados por ato do Poder Executivo } \\
\text { Federal. }\end{array}$ \\
\hline
\end{tabular}

Fonte: Adaptado de Brasil (LDO, 2016).

${ }^{16}$ Em português, Vírus da Imunodeficiência Humana. 
Dessa forma, a redação da LDO tem efeitos sobre a alocação de recursos do orçamento fiscal e da seguridade social ao estabelecer critérios para os repasses de recursos por meio das transferências voluntárias aos Estados-Membros e a entidades privadas sem fins lucrativos.

Diante disso, é de interesse das entidades captadoras de recursos voluntários da União que tenha ciência das fases de elaboração do projeto de Lei de Diretrizes Orçamentárias e capacidade adequada para participarem das discussões no âmbito institucional sobre as diretrizes da elaboração a LOA (estabelecidos na LDO). Dessa forma, o processo de transferências voluntárias possa ser melhorado e as lacunas reduzidas, no intuito de que as parcerias entre os entes públicos e privados ocorram e os objetos de políticas cheguem as seus destinatários.

\subsubsection{A Lei Orçamentária Anual}

Conforme definido pelo art. 165 da Constituição de 1988, a lei orçamentária anual (LOA) é constituída de três orçamentos compatibilizados com o PPA e LDO, quais sejam: orçamento fiscal, orçamento de investimento das empresas estatais e 0 orçamento da seguridade social.

Segundo Garson (2016, p. 499), o orçamento da seguridade social tem como finalidade evidenciar os recursos públicos destinados a direitos relativos às áreas da saúde, à previdência e à assistência social, universalizados pela Constituição.

Já o orçamento fiscal, segundo a Autora, compreende as demais áreas de atuação da União, estados e munícipios: educação, segurança, legislativo, judiciários, habitação, urbanismo e outros.

No caso do orçamento de investimento compreende as despesas realizadas pelas empesas estatais independentes ${ }^{17}$, cujo setor público detenha, direta ou indireta, a maioria do capital social com direito a voto.

O orçamento fiscal e de investimento, além das funções que lhe são próprias, têm como função a de reduzir as desigualdades inter-regionais, segundo critério populacional.

\footnotetext{
17 No caso das empresas dependentes, suas programações, e por consequências as dotações orçamentárias, constarão no orçamento fiscal ou da seguridade social, de acordo com a áreas de atuação.
} 
Segundo Aguilar (2012, p. 298), mediante os três instrumentos consolidados na LOA é realizada a demonstração para a sociedade o que o governo espera realizar, por meio de projetos e atividades que se vinculam a programas de governos estabelecidos no plano plurianual, que viabilizarão a realização das políticas públicas.

Dessa forma, os governos organizam e dão indicativos aos agentes econômicos sobre a intenção de gastos durante um exercício financeiro. Caso não atuem dessa forma estarão descumprindo 0 art. $2^{\circ}$ da Lei 4.320/64, em que determina a "discriminação da receita e da despesa pública, de forma a evidenciar a política econômico-financeira e o programa de trabalho do governo, obedecidos os princípios da unidade, universalidade e anualidade".

Sendo assim, a estrutura do orçamento público brasileiro está organizada em programas de trabalhos, contento informações qualitativas e quantitativas, em relação à previsão de gasto público e a dotação orçamentária correspondente, como forma de torna visível aos diversos interessados a intenção e a realização dos gastos do setor público.

Segundo consta no Manual Técnico do Orçamento - MTO, União, edição 2016, as informações qualitativas da programação orçamentária devem responder de maneira clara e objetiva às perguntas clássicas que caracterizam o ato de orçar, sendo, do ponto de vista operacional, composto dos seguintes blocos de informação: classificação por esfera (em qual orçamento?), classificação institucional (Quem é o responsável por fazer?), classificação funcional (Em que áreas de despesa a ação governamental será realizada?), estrutura programática (Qual o tema da política pública?) e principais informações do Programa (O que se pretende alcançar com a implementação da Política Pública e o que será entregue?) e da Ação (O que será desenvolvido para alcançar o objetivo do programa? O que é feito? Para que é feito? Como é feito? O que será produzido ou prestado? Como é mensurado? Onde é feito? Onde está o beneficiário do gasto?.

Já em relação à programação orçamentária quantitativa, tem a finalidade de apresentar a dimensão física e financeira em relação à quantidade de bens e serviços a ser disponibilizada a sociedade, assim como qual é a estimativa de dotação necessária para a realização da despesa. Esta parte da estrutura de programação é composta pelos classificadores apresentados no Quadro 7, a seguir. 
Quadro 7 - Bloco de informações quantitativas na estrutura de programação orçamentária.

\begin{tabular}{|c|c|}
\hline Item da Estrutura & Pergunta a ser Respondida \\
\hline \multicolumn{2}{|l|}{ Natureza da Despesa } \\
\hline Categoria Econômica da Despesa & $\begin{array}{l}\text { Qual o efeito econômico da realização da } \\
\text { despesa? }\end{array}$ \\
\hline Grupo de Natureza de Despesa (GND) & $\begin{array}{l}\text { Em qual classe de gasto será realizada a } \\
\text { despesa? }\end{array}$ \\
\hline Modalidade de Aplicação & De que forma serão aplicados os recursos? \\
\hline Elemento de Despesa & $\begin{array}{l}\text { Quais os insumos que se pretende utilizar ou } \\
\text { adquirir? }\end{array}$ \\
\hline Identificador de Uso (IDUSO) & Os recursos são destinados para contrapartida? \\
\hline Fonte de Recursos & $\begin{array}{l}\text { De onde virão os recursos para realizar a } \\
\text { despesa? }\end{array}$ \\
\hline $\begin{array}{l}\text { Identificador de Doação e de Operação de } \\
\text { Crédito (IDOC) }\end{array}$ & $\begin{array}{l}\text { A que operação de crédito ou doação os } \\
\text { recursos se relacionam? }\end{array}$ \\
\hline Identificador de Resultado Primário & $\begin{array}{l}\text { Qual o efeito da despesa sobre o Resultado } \\
\text { Primário da União? }\end{array}$ \\
\hline Dotação & Qual o montante alocado? \\
\hline
\end{tabular}

Fonte: MTO 2016 - União.

Conforme observável na Figura 3, a junção dos blocos de informações qualitativos e quantitativos, permitem a organização do processo de orçamentação e na geração de informações relacionadas à avaliação do planejamento, da gestão e do controle do gasto público. Assim como, permitir uma visualização das intervenções estatais e da forma que serão executadas: direta, por parte dos órgãos federais; ou descentralizada, por parte dos participes públicos ou privados em fins lucrativos. 


\begin{tabular}{|c|c|c|c|c|c|c|c|c|c|c|c|c|c|c|c|}
\hline \multicolumn{3}{|c|}{ CÓDIGO COMPLETO* } & 10. & 39. & 252. & 26. & 782. & 2075. & 7M64. & 0043. & 9999. & 0. & 100.4 & 4490. & 2 \\
\hline \multirow[b]{3}{*}{$\begin{array}{l}\mathrm{L} \\
\mathrm{I}\end{array}$} & \multicolumn{2}{|c|}{ Esfera: Orçamento Fiscal } & 10 & & & & & & & & & & & & \\
\hline & \multirow[b]{2}{*}{$\begin{array}{l}\text { CLASSIFICAÇÃO } \\
\text { INSTITUCIONAL }\end{array}$} & Órgão: Ministério dos Transportes & & 39 & & & & & & & & & & & \\
\hline & & $\begin{array}{c}\text { Unidade Orçamentária: } \\
\text { Departamento Nacional de } \\
\text { Infraestrutura de Transportes - } \\
\text { DNIT }\end{array}$ & & & 252 & & & & & & & & & & \\
\hline T & \multirow{2}{*}{$\begin{array}{l}\text { CLASSIFICAÇÃO } \\
\text { FUNCIONAL }\end{array}$} & Função: Transporte & & & & 26 & & & & & & & & & \\
\hline T & & Subfunção: Transporte Rodoviário & & & & & 782 & & & & & & & & \\
\hline \multirow{3}{*}{$\begin{array}{l}\text { I } \\
\text { V } \\
\text { A }\end{array}$} & \multirow{3}{*}{$\begin{array}{l}\text { CLASSIFICAÇ̄̃̃O } \\
\text { PROGRAMÁTICA }\end{array}$} & PROGRAMA: Transporte Terrestre & & & & & & 2075 & & & & & & & \\
\hline & & $\begin{array}{c}\text { AÇÃ0: Construção de Trecho } \\
\text { Rodoviário }\end{array}$ & & & & & & & $7 \mathrm{M} 64$ & & & & & & \\
\hline & & SUBTÍTUL0: Rio Grande do Sul & & & & & & & & 0043 & & & & & \\
\hline \multirow[b]{2}{*}{0} & \multicolumn{2}{|c|}{ IDOC: Outros recursos } & & & & & & & & & 9999 & & & & \\
\hline & \multicolumn{2}{|c|}{ IDUSO: Recursos não destinados à contrapartida } & & & & & & & & & & 0 & & & \\
\hline $\begin{array}{l}N \\
T\end{array}$ & \multicolumn{2}{|c|}{$\begin{array}{l}\text { Fonte de Recursos: Recursos do Tesouro - Exerćício } \\
\text { Corrente (1) Recursos Ordinários (00) }\end{array}$} & & & & & & & & & & & 100 & & \\
\hline $\begin{array}{l}1 \\
\text { T } \\
\text { A }\end{array}$ & \multicolumn{2}{|c|}{$\begin{array}{l}\text { Natureza da Despesa: Categoria Econômica: Despesas } \\
\text { de Capital (4); Grupo de Natureza: Investimentos (4); } \\
\text { Modalidade de Aplicação: Aplicação Direta (90) }\end{array}$} & & & & & & & & & & & & 4490 & \\
\hline $\begin{array}{l}1 \\
\mathrm{~V} \\
\mathrm{~A}\end{array}$ & \multicolumn{2}{|c|}{$\begin{array}{c}\text { Identificador de Resultado Primário: Primária } \\
\text { Discricionária }\end{array}$} & & & & & & & & & & & & & 2 \\
\hline
\end{tabular}

*Código como seria visualizado no SIAFI, exemplo meramente ilustrativo.

Figura 3 - Estrutura da programação orçamentária.

Fonte: MTO União 2016.

Para Garson (2016, p. 503) no sistema de classificação orçamentária, os programas de trabalho na LOA são codificados, de forma não apenas destacar os órgãos e as unidades responsáveis pela despesa - classificação institucional - mas também a identificar a que função e subfunção se destinam - classificação funcional - e a que programa e ação ${ }^{18}$ do PPA se relacionam - classificação programática.

Por meio das classificações orçamentárias, além de viabilizar o planejamento, gestão e controle, é possível também a identificação de programas de trabalhos similares entre o orçamento da União e dos entes subnacionais, em vista de

${ }^{18}$ Ressalta-se que na estratégia atual as ações constarão apenas na LOA, não sendo discriminadas no PPA. 
formação de parcerias por meio dos convênios e contratos de repasses, no intuito de execução dos Programas e Ações, caraterizados como de interesses mútuos.

A Figura 4 ilustra essa situação relativa a estruturas programáticas compatíveis, no que possibilita a soma de esforços interorganizacionais para a realização de políticas públicas. Para o caso, temos a exemplo um Programa de Trabalhos da Unidade orçamentária - 56101 Ministério das Cidades cujo é compatível com o Programa da Unidade 22.101 Secretaria de Obras do Distrito Federal, na forma qualitativa e quantitativa. 


\section{Ōrgão: 56000 Ministério das Cidades \\ Unidade: 56101 Ministério das Cidades}

Quadro dos Créditos orçamentários

\begin{tabular}{|c|c|}
\hline Programática & Programa/Açāo/Produto/Localizaçāo \\
\hline 2048.10SS.7006 & $\begin{array}{l}\text { Apoio a Sistemas de Transporte Público Coletivo Urbano - Obras de Mobilidade } \\
\text { Urbana - Salvador - BA }\end{array}$ \\
\hline & - Sistema apoiado (\% de execucão física): $\quad 100$ \\
\hline 2048.10SS.7008 & $\begin{array}{l}\text { Apo1o a Sistemas de Transporte Público Coletivo Urbano - Reformas e Melhorias } \\
\text { no Terminal Rodoviário Urbano do Plano Piloto - Distrito Federal }\end{array}$ \\
\hline 2048.10SS.7010 & $\begin{array}{l}\text { - Sistema apoiado (\% de execução física) } \quad 100 \\
\text { Apoio a Sistemas de Transporte Público Coletivo Urbano - Obras e Ações de } \\
\text { Apoio à Mobilidade Urbana - Campo Grande - MS }\end{array}$ \\
\hline
\end{tabular}

\section{ORÇAMENTO DO GDF}

22. - SECRETARIA DE ESTADO DE OBRAS DO DISTRITO FEDERAL

22.101 - SECRETARIA DE ESTADO DE OBRAS DO DISTRITO FEDERAL

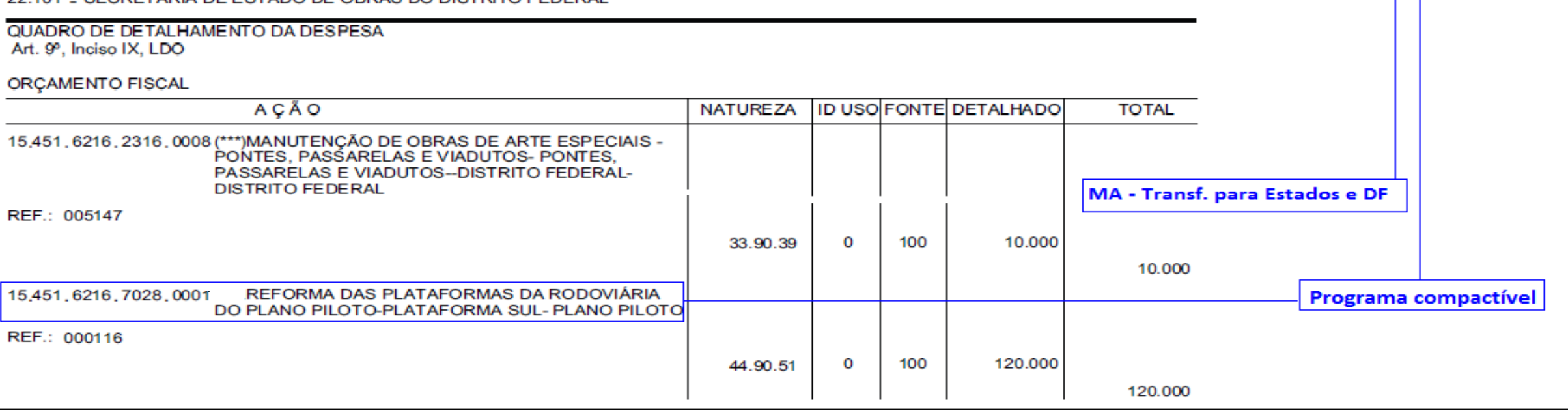

Figura 4 - Análise de compatibilidade entre as programações orçamentárias da União em relação às do Governo do Distrito Federal.

Fonte: Lei Orçamentária Anual - União e Distrito Federal, exercício 2013. 
Esse grau de compatibilidade está relacionado às interações entre os setoriais de orçamento, de ambas as esferas administrativas. Dessa forma, as parcerias intergovernamentais, representadas pelas unidades orçamentárias e efetuadas por meio de acordos de transferências voluntárias, são desenhadas na fase de elaboração e discussão das peças orçamentárias, de ambos os possíveis parceiros.

Dois fatos nos ajudam compreender a necessidade de interação entre estruturas de orçamentação diferentes para alinhar estratégias de execuções públicas em forma de parceiras.

O primeiro fato é que parte das políticas públicas da União são executadas de forma descentralizada, nas seguintes Modalidades de Aplicação:

- 30 - Transferências a Estados e DF;

- 30-40 - Transferências a Municípios; e

- 31-50 - Transferências a entidades privadas sem fins lucrativos.

O segundo fato, nas peças orçamentárias há viés de incrementalismo, ou seja, determinadas estruturas de programações orçamentárias repetem-se ano após ano, permitindo certa previsibilidade das programações orçamentárias anuais devido aos orçamentos não terem uma variação abrupta nas programações. E o caso das programações orçamentárias relacionadas às funções típicas de Educação, Saúde, Segurança Pública, Agricultura, Desporto e Lazer etc.

Conforme apontado por Sousa (2006, p. 10), a visão da política pública como um processo incremental foi desenvolvida por Lindblom (1979), Caiden e Wildavsky (1980) e Wildavisky (1992), com base em pesquisas empíricas, os autores argumentaram que os recursos governamentais para um programa, órgão ou uma dada política pública não partem do zero e sim, de decisões marginais e incrementais que desconsideram mudanças políticas ou mudanças substantivas nos programas públicos. Assim, as decisões dos governos seriam apenas incrementais pouco substantivas.

Diante desses fatos, é possível uma aproximação entre as programações orçamentárias dos entes federados em vistas de proporcionar uma maior integração de ações públicas, permitindo assim a formação de parcerias para a execução compartilhada, por meio das transferências voluntárias da União. 
No processo de orçamentação federal podemos observar essas "janelas de oportunidades" em dois momentos, conforme apresentado nas Figuras 6 e 7.

Primeiro momento está na elaboração das propostas orçamentária da União, por parte dos diversos órgãos setoriais que compõe sua estrutura orgânica, em que há abertura para apresentações, nas audiências públicas ou diretamente as unidades federais, das demandas sociais captadas pelos órgãos dos entes subnacionais (vide Figura 5, a seguir).

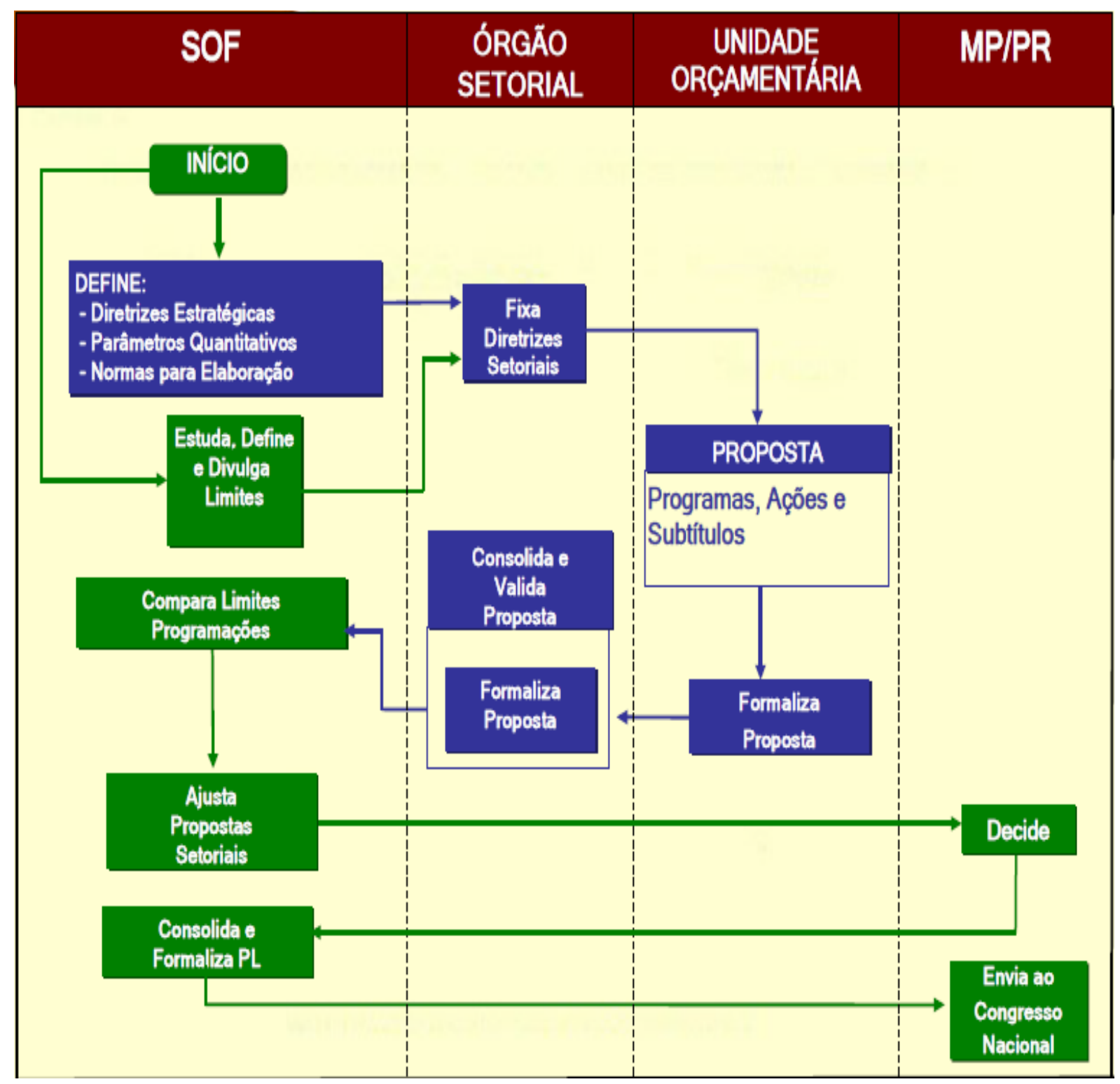

Figura 5 - Primeira janela de oportunidade no processo orçamentário.

Fonte: MTO 2016 
O segundo momento é possível quando da apreciação do Projeto de Lei do Orçamento Anual (PLOA), por parte dos parlamentares do Congresso Nacional. Nessa segunda "janela de oportunidade" os entes subnacionais, por meio dos representantes eletivos, podem apresentar sua demandas no intuito de buscar por alocações de recursos nas suas respectivas áreas de abrangência, por meio das emendas parlamentares (Figura 6).

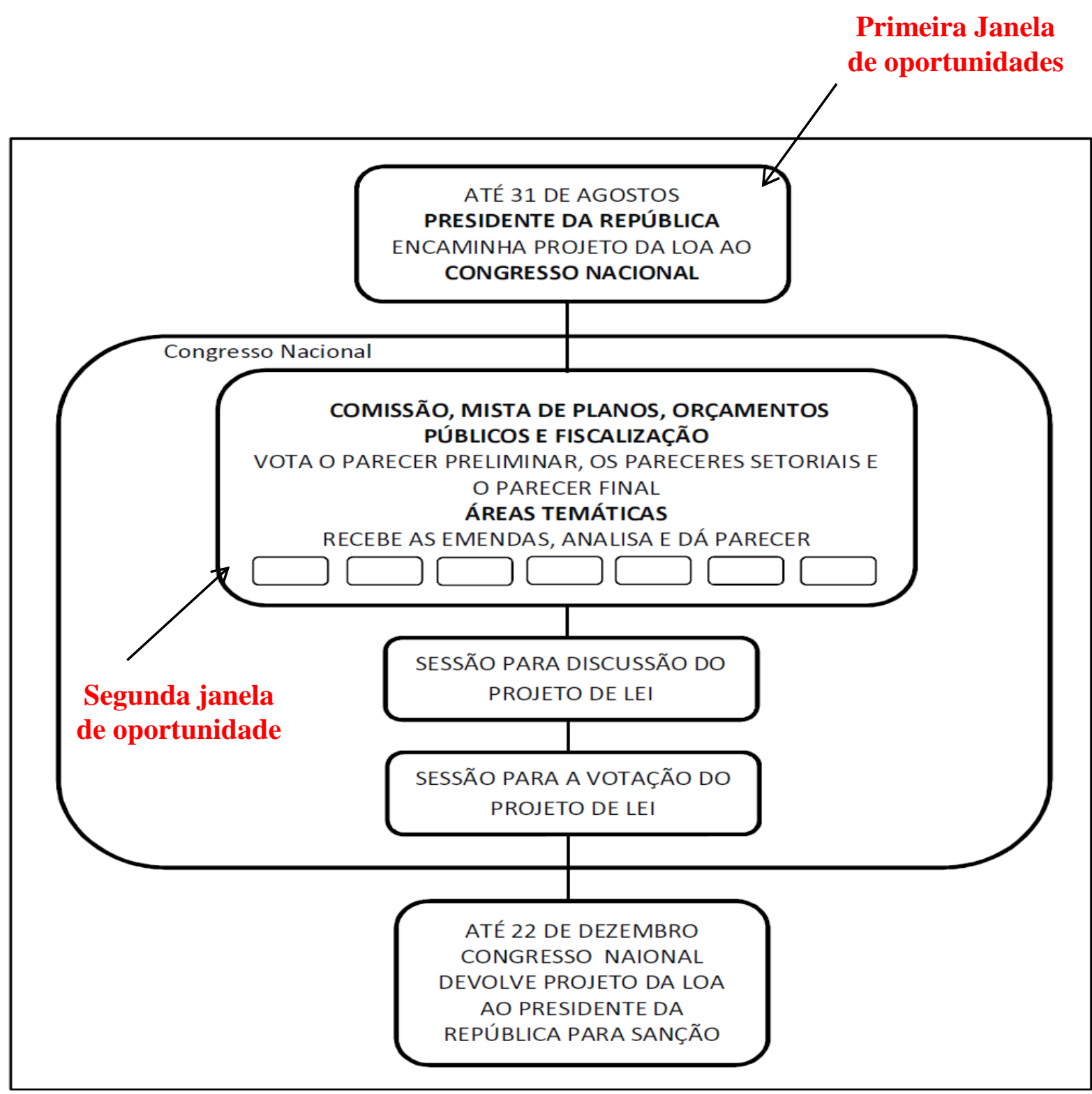

Figura 6 - Segunda janela de oportunidade no processo orçamentário.

Fonte: Adaptado de Giacomoni (2008). 
Diante das "janelas de oportunidades", temos três formas para a destinação dos recursos de transferências voluntárias dos órgãos federais aos estaduais, municipais e DF, por meio da aproximação dos planos públicos, quais sejam: Proponentes específicos, de emendas parlamentares e de propostas voluntárias.

\section{a) 1ํㅡㄹ forma: Propostas para proponentes específicos}

São direcionamentos de recursos pelos órgãos da União a entidades que apresentem projetos factíveis para a execução dos objetos de políticas alocados no Orçamento Fiscal e da Seguridade Social da União.

A interação com os órgãos da União pode ocorrer durante a execução orçamentária ou (mais indicado) na fase de elaboração das peças orçamentárias. Dessa forma, são recursos que tem maiores possibilidade de serem captados, assim como as emendas parlamentares.

\section{b) 2a forma: Proponentes de emenda parlamentar}

Emendas são os instrumentos que dispõe os parlamentares do Congresso Nacional, para procederem aos ajustes, acréscimos, supressão ou modificação nos projetos de Lei de Orçamento da União, com a consequente realocação de recursos na proposta elaborada e enviada pelo executivo.

$\mathrm{Na}$ fase de discursão do Projeto de Lei de Orçamento Anual, poderá haver pelos parlamentares a realocação de recursos, com a possibilidade de indicação de dotações para a execução de forma descentralizada a ser realizada por entidades específicas.

Diante disso, é necessária a interação de representes dos órgãos distritais perante os parlamentares da Casa Legislativa da União, para que apresentem propostas de objetos de políticas públicas, cujos poderão ter adesão pelos congressistas, possibilitando assim a indicação e a execução, mediante a descentralização dos recursos do Orçamento Fiscal e da Seguridade Social, via transferências voluntárias, para os órgãos solicitantes dos recursos. 
c) 3o forma: Proponente de propostas voluntárias:

São recursos abertos para a realização de propostas pelas diversas entidades, públicas ou privadas sem fins lucrativos, para posterior seleção dos projetos pelos órgãos da União daqueles que sejam mais consistentes e adequados as suas políticas.

Os recursos de proponentes discricionários têm maior concorrência entre as diversas entidades captadoras de recursos.

Portanto, o maior contato com as unidades orçamentárias da União permitem aos parceiros subnacionais anteciparem 0 processo de alinhamento de programações para a formação de parceiras com a União, por meio das transferências voluntárias, contribuindo para uma maior coordenação e elaboração de planos de trabalhos em tempo hábil, para que sejam executadas de forma adequada as políticas públicas pactuadas.

\subsubsection{Gestão Pública}

Gestão é um ramo das ciências humanas porque trata com grupo de pessoas, procurando manter sinergia entre elas, a estrutura organizacional e os recursos existentes disponíveis, a fim de serem atingidos os objetivos pré-determinados. Surgiu quando, após a revolução industrial, os profissionais decidiram buscar solução para problemas que não existiam antes, usando vários métodos de ciências para administrar negócios da época, o que deu inicio a ciência da administração, pois é necessário o conhecimento e a aplicação de modelos e técnicas administrativas (Neves, 2012, p. 222).

Ainda, Gestão significa gerenciamento, administração, onde existe uma instituição, uma empresa, uma entidade social de pessoas a ser gerida ou administrada, cujo objetivo é de crescimento estabelecido pela instituição atreves do esforço humano organizado pelo grupo (NEVES, 2012).

Por outras palavras, segundo Neves (2012), cabe à gestão a otimização do funcionamento das organizações através da tomada de decisões racionais e fundamentadas na escolha e tratamento de dados e informações relevantes para, por essa via, contribuir para seu desenvolvimento e satisfação dos interesses de 
todos os seus colaboradores e proprietários, além da satisfação das necessidades da sociedade em geral ou de um grupo particular.

Segundo Malmegrin (2010, p. 13), a qual não faz diferenciação entre os termos "Gestão" ou "Administração", gestão é "um conjunto de princípios, normas e funções que tem por objetivo ordenar os fatores de produção e controlar a sua produtividade e sua eficiência para obter determinado resultado".

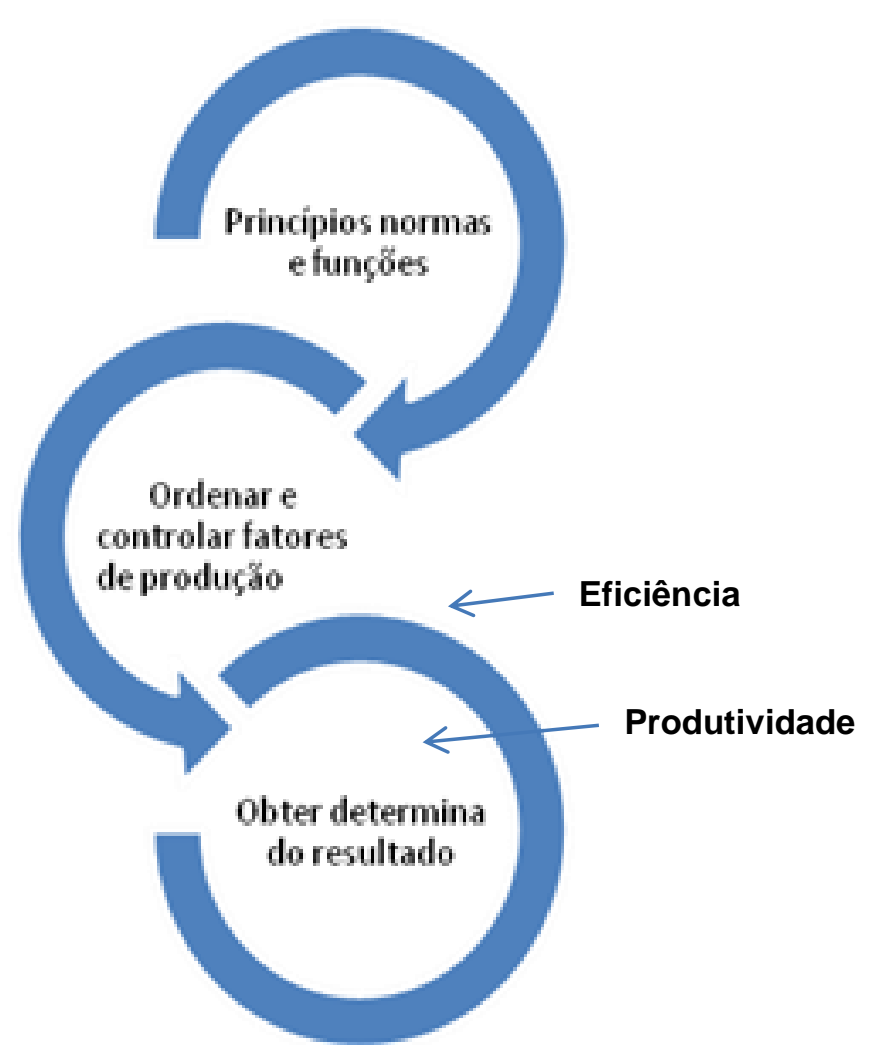

Figura 7 - Atributos e função do processo de gestão.

Fonte: Adaptado de Malmegrin (2010).

A gestão pública materializa-se na organização pública que, segundo Castro (2012, p. 364) é derivada de um grupo humano, uma estrutura e uma dinâmica de relacionamento de seus vários elementos componentes objetiva, sobretudo, a satisfação de necessidades coletivas.

Conforme apontado por Bryner (2010, p. 315), "A principal tarefa das organizações públicas é implementar as políticas aprovadas pelos governos. Por sua vez, a boa realização dos objetivos das políticas importantes é, em grande parte, função da capacidade da administração pública”. 
Entretanto, um desafio é apresentado no caso dos acordos interorganizacionais em que a gestão dos recursos e execução dos objetos das políticas públicas deve, em tese, ser efetuadas de forma conjunta, ou seja, o órgão repassador em paralelo a entidade recebedora dos recursos financeiros.

Sendo assim, questões sobre esse processo se colocam: a União possui capacidade operacional para analisar todos os planos de trabalho com a necessária crítica para a aprovação somente daqueles que possuem viabilidade para uma boa execução das politicas públicas? Possui quadro suficiente de pessoal e qualificado para o acompanhamento da execução desses planos de trabalho? Possui quadro suficiente e qualificado para a análise das prestações de contas e, quando necessário, a abertura de tomadas de contas especiais?

O que se observa atualmente é a aprovação de projetos de captação de recursos incompletos, sendo necessário ajuste durante a execução para alinhar as metas, etapas, cronograma físico-financeiro e os objetos de despesa aos objetivos do plano de trabalho. O baixo acompanhamento da execução e um volume expressivo de prestações de contas sem analise.

Muitas dessas questões têm início na incapacidade operacional dos órgãos da União em analisar, acompanhar e exigir a prestação de contas dos inúmeros acordos de transferências voluntárias firmados com diversos órgãos e organizações privadas sem fins lucrativos dos 26 estados da federação, Distrito Federal e de 5570 municípios.

A gestão pública nesse contexto e de acordo com Matias-Pereira (2009), pode ser entendida como a governança de uma rede complexa, integrada por inúmeros e distintos atores como partes do governo local, regional e nacional, cujos objetivos e interesses são conflitantes.

Diante disso, há uma grande oportunidade e um enorme desafio para a gestão pública em formular e implantar modelos de gestão em relação à sistemática de celebração de acordos e a execução e prestação de contas desses recursos de transferências voluntárias da União, no intuito de maior eficiência, eficácia e efetividade do processo em si e da disponibilização dos objetos dos acordos a população focal das políticas públicas realizadas de forma descentralizada por parte dos entes subnacionais e organizações da sociedade civil. 


\subsubsection{Atividade de controle sobre a Gestão Pública}

O Controle da Gestão Pública realiza-se mediante a adoção de um amplo conjunto de mecanismos, jurídicos e administrativos, por meio dos quais se exerce 0 poder de fiscalização e de revisão da atividade de todos os agentes públicos, em qualquer esfera de governo e em todos os poderes da república, sempre tendo como fundamento o princípio da legalidade (ALBUQUERQUE ET AL., 2013, p. 384).

Ainda, recai sobre a gestão pública o necessário poder fiscalizatório exercido pelos administrados, ou seja, o controle realizado pelos cidadãos no seu poder e dever de acompanhar as ações estatais e acionar os mecanismos de defesa quanto às irregularidades ou ilegalidades no processo de gestão da coisa pública.

Diversos dispositivos legais fazem referências à atividade de controle, tais como Constituição Federal de 1988, Decreto n 4.320/1964, Decreto-Lei n 200/1967 etc., no entanto citamos a definição dada pela Portaria Interministerial $n^{\circ} 507 / 11$, cuja faz referência ao necessário controle quanto às gestões das transferências de recursos intergovernamentais, do tipo transferências voluntárias.

Segundo o Inciso IX, $\S 2^{\circ}$, do art. $1^{\circ}$, da PI n ${ }^{\circ} 507 / 11$, órgãos de controle "são instituições vinculadas aos Poderes Executivo e Legislativo da União, dos estados, do Distrito Federal e dos municípios, que possuem designação constitucional para orientar, auditar, fiscalizar e acompanhar a execução dos programas, projetos e atividades de governo nos aspectos de legalidade, economicidade e eficiência".

Após essa breve exposição, podemos representar o controle sobre as atividades da Administração Pública, quanto à provedora de serviços públicos, em três vertentes: Controle Interno, Controle Externo e Controle Social.

\subsubsection{Controle externo}

O poder institucionalizado de fiscalização sobre a administração pública é papel tanto do controle interno quanto do externo.

Segundo Harada (2007, p. 120) o controle externo depreende-se dos arts. 70 e 79, inciso X, da CF, sendo exercido exclusivamente pelo Congresso Nacional, com auxílio do Tribunal de Contas da União (TCU), que, de acordo com os mesmo fins do Controle Interno, objetiva a fiscalização contábil, financeira, orçamentária, operacional e patrimonial dos entes constitucionais e das entidades da 
Administração direta e indireta, utilizando como parâmetros a legalidade, legitimidade, economicidade, aplicação das subversões e renúncia de receitas.

Segundo o que dispõe o Parágrafo Único, do art. 70, da CF 88:

Prestará contas qualquer pessoa física ou jurídica, pública ou privada, que utilize, arrecade, guarde, gerencie ou administre dinheiros, bens e valores públicos ou pelos quais a União responda, ou que, em nome desta, assuma obrigações de natureza pecuniária.

Como regra infraconstitucional, o Controle Externo também está previsto na Lei 4.320/64, a qual estatui normas gerais de direito Financeiro para elaboração e controle dos orçamentos e balanços da União, dos Estados, dos Municípios e do Distrito Federal .

Está disposto nos arts. 81 e 82 dessa Lei que:

Art. 81. O contrôle da execução orçamentária, pelo Poder Legislativo, terá por objetivo verificar a probidade da administração, a guarda e legal emprêgo dos dinheiros públicos e o cumprimento da Lei de Orçamento.

Art. 82. O Poder Executivo, anualmente, prestará contas ao Poder Legislativo, no prazo estabelecido nas Constituições ou nas Leis Orgânicas dos Municípios.

$\S 1^{\circ}$ As contas do Poder Executivo serão submetidas ao Poder Legislativo, com Parecer prévio do Tribunal de Contas ou órgão equivalente.

$\S 2^{\circ}$ Quando, no Município não houver Tribunal de Contas ou órgão equivalente, a Câmara de Vereadores poderá designar peritos contadores para verificarem as contas do prefeito e sôbre elas emitirem parecer.

Segundo Oliveira (2013, p. 25), o Controle Externo pode ser feito por iniciativa própria do TCU ou em decorrência de solicitação do Congresso Nacional, cujo Tribunal pode utilizar de cinco instrumentos:

a) Levantamento: instrumento utilizado para conhecer a organização e o funcionamento de órgão ou entidade pública, de sistema, programa, projeto ou atividade governamental, identificar objetos e instrumentos de fiscalização e avaliar a viabilidade de sua realização;

b) Auditoria: por meio desse instrumento verifica-se in loco a legalidade e a legitimidade dos atos de gestão, quanto ao aspecto contábil, financeiro, orçamentário e patrimonial, assim como o desempenho operacional e os resultados alcançados de órgãos, entidades, programas e projetos governamentais; 
c) Inspeção: serve para a obtenção de informações não disponíveis no Tribunal, ou para esclarecer dúvidas; também é utilizada para apurar fatos traduzidos ao conhecimento do Tribunal por meio de denuncias ou representações;

d) Acompanhamento: destina-se a monitorar e avaliar a gestão do órgão, entidade ou programa governamental por período de tempo predeterminado;

e) Monitoramento: é utilizado para aferir o cumprimento das deliberações do Tribunal e dos resultados delas advindos.

Em relação ao instrumento citado por Oliveira (2013), no item "c", podemos citar como modalidades daquele a auditoria de regularidade e a auditoria de otimização de recursos.

De acordo com as normas da Organização Internacional de Entidades Fiscalizadoras Superiores - INTOSAI, citado por Silva (2009, p. 59), a auditoria de regularidade tem por ações:

a) Certificar que as entidades responsáveis cumpriram sua obrigação de prestar contas, o que envolve o exame e a avaliação dos registros financeiros e a emissão de parecer sobre as demonstrações financeiras;

b) Emitir parecer sobre as contas do governo;

c) Auditar os sistemas e as operações financeiras, incluído o exame da observância às disposições legais e regulamentares aplicáveis;

d) Auditar os controles internos e as funções de auditoria interna;

e) Auditar a probidade de a propriedade das decisões administrativas tomadas pela entidade auditada; e

f) Informar sobre quaisquer outros assuntos, decorrentes ou relacionados com a auditoria, que EFS ${ }^{19}$ considere necessário revelar.

Quanto à auditoria de otimização de recursos, em que também e denominada de auditoria de gestão, de desempenho ou de resultado ou operacional, segundo Silva (2009, p. 60) surgiu nos anos 70/80, do século XX, por força do clamor da sociedade em relação à correta aplicação dos recursos públicos no que tange ao conteúdo as informações prestadas à sociedade.

\footnotetext{
${ }^{19}$ Entidades Fiscalizadoras Superiores, a exemplo os Tribunais de Contas.
} 
De acordo com a INTOSAI, conforme citado por Silva (2009), a auditoria de otimização de recursos preocupa-se em verificar a economia, a eficiência e a eficácia, e tem por função:

a) Determinar se a administração desempenhou suas atividades com economia, de acordo com os princípios, praticas e politicas administrativas corretas;

b) Determinar se os recursos humanos, financeiros e de qualquer outra natureza são utilizados com eficiência, incluído o exame de procedimentos de mensuração e controle de desempenho e as providencias adotadas pelas entidades auditadas para sanar as deficiências detectadas; e

c) Determinar a eficácia do desempenho das entidades auditara em ralação ao alcance de seus objetivos e avaliar os verdadeiros efeitos de suas atividades em comparação com o efeito esperado.

Sendo assim, em tese aqueles que tenham como função a gestão dos recursos de transferências voluntárias da União são passíveis de um duplo controle externo: o realizado pelo $\mathrm{CN}$, com o auxílio do TCU, e os realizados pelas assembleias legislativas ou câmaras municipais, por meio dos respectivos Tribunais de Contas.

Atualmente o sistema de controle externo pátrio conta com o auxilio 34 Cortes de Contas, conforme distribuição ilustrada no Quadro 8, a seguir.

Quadro 8 - Tribunais de Contas presentes na estrutura orgânica da administração pública brasileira.

\begin{tabular}{|l|l|c|}
\hline \multicolumn{1}{|c|}{ Tribunal de Contas } & \multicolumn{1}{c|}{ Atuação } & Quantidade \\
\hline Tribunal de Contas da União & União & 01 \\
\hline Tribunal de Contas do Estado & Estados-Membro & 26 \\
\hline Tribunal de Contas do Distrito Federal & Distrito Federal & 01 \\
\hline Tribunal de Contas dos Municípios & Pará, Bahia e Ceará e Goiás & 04 \\
\hline Tribunal de Contas do Município & São Paulo e Rio de Janeiro & 02 \\
\hline
\end{tabular}

Fonte: Elaborado pelo autor.

No entanto, segundo Silva (2009, p. 59), as atividades de fiscalização das contas públicas exercidas pelos tribunais de contas têm pautado dentro do que se denomina "auditoria de regularidade", ou seja, a auditoria financeira conjugada com a de cumprimento legal. 
A afirmação de Silva (2009) alinha-se a de Machado Jr (2015, p. 162), em que este Autor tece críticas à atividade de fiscalização exercida pelos órgãos de controle brasileiro, cujos se voltam para um controle legalístico, sobrepujando o controle em referência ao cumprimento do programa de trabalho, em termos de dinheiro e realização de obras ou serviços, trazidos pela Lei 4.320/64.

De acordo com o manual de Auditoria do TCU, a "auditoria de natureza operacional consiste na avaliação sistemática dos programas, projetos, atividades e sistemas governamentais, assim como dos órgãos e entidades jurisdicionadas ao Tribunal" (GIACOMONI, 2008, p. 347).

A auditoria de natureza operacional compreende duas modalidades: auditoria de desempenho operacional e avaliação de programa.

Segundo Giacomoni (2008, p. 348), o objetivo da auditoria de desempenho organizacional é examinar a ação governamental quanto aos aspectos da economicidade, eficiência e eficácia, considerando os seguintes aspectos:

- Como os órgãos e entidades pública adquirem, protegem e utilizam seus recursos;

- As causas práticas antieconômicas e ineficientes;

- O cumprimento das metas previstas;

- A obediência aos dispositivos legais aplicáveis aos aspectos da economicidade, eficiência e eficácia da gestão.

Em relação à auditoria de avaliação de programa, segundo Giacomoni (2008, p. 349) tem por finalidade apurar a efetividade dos programas e ações governamentais, ou seja, apurar em que medida as ações executadas produziram seus resultados pretendidos.

Portanto, a realização de auditorias operacionais é o caminho para promoção de uma melhor gestão dos recursos voluntários transferidos da União para os entes subnacionais e entidades privadas sem fins lucrativos. Protegendo os recursos de gestões temerárias e avaliando o impacto dos produtos das políticas públicas da União, executados de forma descentralizada.

Sendo assim, há a necessidade de maior número de ações de controle representadas pelas auditorias operacionais, sobretudo em relação às transferências voluntárias da União aos entes subnacionais e entidades privadas sem fins lucrativos, haja vista a quantidade e volume de recursos da União repassados a tais 
entidades para a execução indireta de politicas públicas, pactuadas por meio de convênios, contratos de repasses e termos de fomento ou em acordos de cooperação.

\subsubsection{Controle interno}

A instituição do controle interno na administração pública brasileira teve seu marco inaugural com a edição da Lei 4.320/1964 (ALBUQUERQUE et al., 2013, p. 393). No inciso I, do artigo 75, dessa Lei, segundo Machado Jr. (2015, p. 161), define a universalidade do controle, o qual abrange todos os atos da Administração, sem exceção, que tratem da receita ou da despesa; quer se tratem de atos que repercutem no ativo (nascimento ou extinção de direitos) ou no passivo (nascimento ou extinção de obrigações).

Para Albuquerque et al. (2013, p. 393), "Controle Interno é aquele realizado por estruturas organizacionais instituídas no âmbito da própria entidade controlada, compreendendo um conjunto de atividades, planos, métodos e procedimentos estruturados e integrados. Tem como propósito garantir que os objetivos organizacionais sejam alcançados, assim como evidenciar desvios e indicar as correções a ajustes que se mostrem necessários ou oportunos".

Desta forma, pode-se inferir que controlar também é assegurar que os recursos obtidos pela administração pública sejam aplicados de maneira racional e econômica e, portanto, de forma eficiente e eficaz, gerando efetivas ações para a sociedade (AGUILAR, 2012, p. 96). Ou seja, o controle interno como uma das funções do processo de planejamento e gestão dos recursos públicos tem como função averiguar se as atividades exercidas pelos gestores públicos então em consonância ao que foi planejando, considerando a legalidade, legitimidade e economicidade.

O controle interno no âmbito da Administração Pública, segundo Aguilar (2012, p. 96), "regem-se por meio da instituição e funcionamento do sistema de controle interno cujo objetivo é estabelecer um conjunto de normas, planos, métodos e procedimentos interligados, que visam regular as atividades exercidas".

Nesse ponto é importante fazer distinção entre órgãos de controle interno e sistemas de controle interno. Em âmbito federal, coube ao Tribunal de Contas da União (TCU), por meio da Instrução Normativa $n^{\circ} 57 / 2008$, abordar sobre essa 
distinção, sintetizada no Quadro 9, a seguir, em conformidade a apresentação de Albuquerque (2013, p. 393).

Quadro 9 - Distinção entre controles internos e órgãos de controle interno.

\begin{tabular}{|c|c|}
\hline $\begin{array}{l}\text { Controles Internos } \\
\text { (sistemas e procedimentos) }\end{array}$ & $\begin{array}{l}\text { Órgãos de Controle Interno } \\
\text { (organizações e instituições) }\end{array}$ \\
\hline $\begin{array}{l}\text { Conjunto de atividades, planos, métodos, } \\
\text { indicadores e procedimentos interligados } \\
\text { utilizados com vistas a assegurar a conformidade } \\
\text { dos atos de gestão e concorre para que os } \\
\text { objetivos e metas estabelecidos para as } \\
\text { unidades jurisdicionadas sejam alcançados. }\end{array}$ & $\begin{array}{l}\text { Unidade administrativas integrantes dos } \\
\text { sistemas de controle interno da administração } \\
\text { pública federal, incumbidos, dentre outras } \\
\text { funções, da verificação da consistência e } \\
\text { qualidade dos controles internos, bem como do } \\
\text { apoio às atividades de controle externo exercido } \\
\text { pelo Tribunal. }\end{array}$ \\
\hline
\end{tabular}

Fonte: Albuquerque et al. (2013).

Dessa forma, o sistema de controle interno tem como função estabelecer atributos e procedimentos em um processo de gestão, no intuito de auxiliar uma organização no alcance das suas metas e objetivos definidos, cujo controle fica a cargo de uma unidade administrativa, um órgão de controle interno.

No âmbito do poder executivo federal, o Sistema de Controle Interno está expresso no Decreto $\mathrm{n}^{\circ}$ 3.591, de 6 de setembro de 2000, é composto pela Controladoria-Geral da União (CGU $)^{20}$, como Órgão Central, incumbido da orientação normativa e da supervisão técnica dos órgãos que compõem o Sistema; pela as Secretarias de Controle Interno (CISET) da Casa Civil, da Advocacia-Geral da União, do Ministério das Relações Exteriores e do Ministério da Defesa, como órgãos setoriais; e as unidades de controle interno dos comandos militares, como unidades setoriais da Secretaria de Controle Interno do Ministério da Defesa.

No poder legislativo, as duas casas legislativas possuem unidades de controles próprias. No Senado Federal, é representada pela Secretaria de Controle Interno (SCI), derivada da Antiga Auditoria, criada em 1984 e substituída pela atual em 1993. Com a mesma nomenclatura, na Câmara dos Deputados conta com uma $\mathrm{SCI}$, vinculada à Mesa Diretora.

$20 \mathrm{Na}$ reformulação administrativa instituída pelo Presidente Interino do Poder Executivo Federal, Michael Temer, a nomenclatura Controladoria-Geral da União (CGU) deixa de existir e passa a ser um Ministério intitulado de Ministério da Transparência , Fiscalização e Controle (Maio de 2016). 
Apesar de cada poder possuir suas unidades de controle interno, devem ser mantidos de forma integrada pelos três poderes da República, conforme mandamento Constitucional:

\footnotetext{
Art. 74. Os Poderes Legislativo, Executivo e Judiciário manterão, de forma integrada, sistema de controle interno com a finalidade de:

I - avaliar o cumprimento das metas previstas no plano plurianual, a execução dos programas de governo e dos orçamentos da União;

II - comprovar a legalidade e avaliar os resultados, quanto à eficácia e eficiência, da gestão orçamentária, financeira e patrimonial nos órgãos e entidades da administração federal, bem como da aplicação de recursos públicos por entidades de direito privado;

III - exercer o controle das operações de crédito, avais e garantias, bem como dos direitos e haveres da União;

IV - apoiar o controle externo no exercício de sua missão institucional.
}

Finalmente, sem viés de subordinação, o controle interno também atua como suporte para o controle externo. Segundo a doutrina de Hely Lopes de Meireles, citado por Harada (2007. P. 119), o controle interno tem por objetivo a "criação de condições indispensáveis à eficácia do controle externo e visa assegurar a regularidade da realização da receita $\mathrm{e}$ da despesa, possibilitando o acompanhamento da execução do orçamento, dos programas de trabalhos e a avaliação dos respectivos resultados. É na sua plenitude, um controle de legalidade, conveniência, oportunidade e eficiência".

Trazendo o assunto para os repasses de recursos de transferências voluntárias da União aos entes subnacionais, verifica-se que sobre tais recursos há um duplo controle interno e externo (controle externo foi abordado no tópico 2.6.3.1).

Ao efetuar acordos de parceiras, tanto os integrantes do controle interno e externo da União, quanto aos dos entes subnacionais, devem manter o suporte necessário de recursos humanos e matérias, com o objetivo de assegurar que os repasses financeiros sejam utilizados de forma proba, em atendimento a legislação e vinculados ao objeto do acordo.

Ainda de acordo com o inciso III, art, 75, da Lei 4.320/64, o controle da execução orçamentária deve compreender o "cumprimento do programa de trabalho expresso em termos monetários e em termos de realização de obras e prestação de serviços".

Segundo, Machado Jr (2015, p. 162) o controle do cumprimento do programa de trabalho, em termos de dinheiro e realização de obras ou serviços, foi uma inovação trazida pela Lei 4.320/64. Trouxe a necessidade de controles em termos de 
execução físico-financeira, de prazos e de custos; e não apenas um controle legalístico.

Porém, apesar de passados 51 anos de publicação da Lei 4.320/64, segundo Machado Jr. (2015, p. 162) "esse tipo de controle não evoluiu como seria de desejar na maioria dos órgãos do controle no Brasil, contenta-se com os controles jurídico e contábil-financeiro".

Dessa forma, além de controles jurídico e contábil-financeiro, os agentes de controle devem realizar procedimentos para auxiliar a entidade a atingir seus objetivos, mesmo sabendo das limitações e custos derivados do próprio controle.

Segundo Albuquerque et al (2013, p. 395), os sistemas de controle internos proporcionam uma garantia razoável, mas nunca absoluta de que os objetivos organizacionais serão atingidos. Isso ocorre devido, principalmente, a:

a) Relação custos $x$ benéfico: todo controle tem um custo, que deve ser inferior à perda decorrente da consumação do risco controlado;

b) Conluio entre empregados da mesma maneira que as pessoas são responsáveis pelos controles, estas pessoas podem valer-se de seus conhecimentos e competências para burlar os controles, com objetivos ilícitos;

c) Eventos externos: eventos externos estão além do controle de qualquer organização.

No entanto, mesmo com essas limitações, há a necessidade de maior número de ações de controle representadas pelas auditorias operacionais, em atendimento ao art. $7^{\circ}$, do Decreto $n^{\circ} 3.591 / 2000$, sobretudo em relação às transferências voluntárias da União aos entes subnacionais e entidades privadas sem fins lucrativos, haja vista a quantidade e volume de recursos da União repassados a tais entidades para a execução indireta de políticas públicas, pactuadas por meio de convênios, contratos de repasses e termos de fomento ou em acordos de cooperação.

\subsubsection{Controle social}

A busca pela transparência do Estado brasileiro foi inserida na agenda política de democratização do país, após 21 anos de ditadura militar. A democratização do Estado tinha como um dos seus pressupostos o controle do seu aparelho pela sociedade civil. Para tal, a transparência do Estado, expressa na possibilidade de 
acesso do cidadão à informação governamental, constituía um requisito fundamental. Configurada como um direito e, simultaneamente, projeto de igualdade, o acesso à informação governamental somou-se a outras perspectivas democratizantes (JARDIM, 1999, p.197. apud RAUSCH E SOARES, 2010, p. 36).

Segundo Paul Singer, apud Ferreira (2006, p. 6), a redemocratização brasileira ocorrida entre o final dos anos 1970 e meados da década de 1980 trouxe à tona novos paradigmas de democracia, sendo que na década seguinte esse processo de modernização e de consolidação da democracia obrigou o Estado a ser ver frente a frente como novos é inéditos modelos de gestão pública, de viés mais participativo e popular, produzindo, então, um choque com o modelo de gestão "centralizador e impositivo" típicos dos anos de chumbo.

Para Lopes (2009, p. 10), especificamente em 1988, com a nova constituição federal foi onde o País ratificou a transição da ditadura para a democracia. Com a nova constituição, foram estabelecidos alguns princípios fundamentais para se garantir maior transparência governamental. Portanto, desde a constituição de 1988, é regra que toda informação pública deva ser disponibilizada a qualquer cidadão.

Registra-se que a expressão "Transparência Governamental”, não se confunde com o Princípio da Publicidade, previsto na CF/88. Porém, são complementares, pois a publicidade dos atos administrativos em veículos oficiais de comunicação para conhecimento público é determinante para eficácia; por seu turno a transparência engloba a função de divulgar os atos e fatos de gestão, assim como acrescenta questões como: acesso e canais pré-estabelecidos para conquista da informação, formato de divulgação em forma simples, sem o tecnicismo das áreas governamentais, dentre outros.

Dessa forma, o simples fato da informação sobre os atos do governo esta disponível não garante que ela se torne efetivamente pública ou inteligível ao cidadão comum. Em outras palavras, não se pode confundir informação disponível com informação inteligível e compreensível.

Neto (2011) lista alguns requisitos para a efetiva transparência dos dados sobre as contas públicas à sociedade, conforme se pode observar na Figura 8, a seguir. 


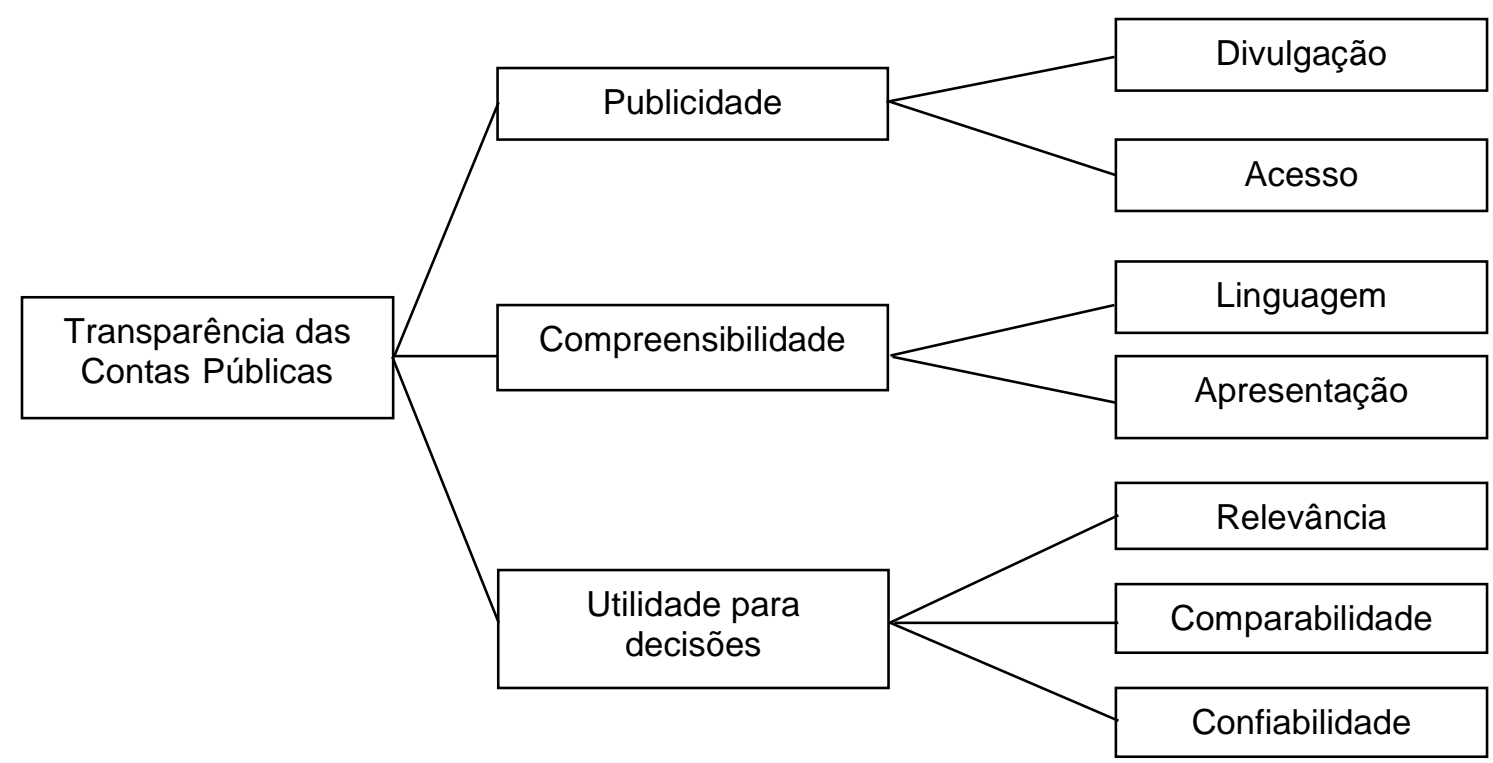

Figura 8 - Elementos da transparência das contas públicas.

Fonte: Neto et al. (2011).

Para Culau e Fortis (2006, p. 1), conferir transparência, além de se constituir em um dos requisitos fundamentais da boa governança, cumpre a função de aproximar o Estado da sociedade, ampliando o nível de acesso do cidadão às informações sobre a gestão pública. Os governantes, ao estarem obrigados a prestar contas de sua gestão, submetem o seu desempenho à avaliação da sociedade.

Segundo Stiglitz, apud Lopes (2009, p. 7), há evidências de que governos mais transparentes funcionam melhor e são mais eficientes. Portanto, permitir o acesso público à informação é uma ferramenta para se garantir o objetivo de ter um Estado que funciona melhor e com menos dispêndio de recursos. Informação publicamente debatida é, em tese, informação de melhor qualidade. Essa informação, quando utilizada para a vigilância das ações estatais, pode resultar em alocações mais honestas e inteligentes, redundando em maior eficácia das políticas públicas e do dispêndio governamental.

Ainda, para Torres (2004, P. 42), "A ampla difusão da informação também abre oportunidades para que 0 usuário/cidadão possa interagir como os formuladores/executores, com provável ganho no aprimoramento de políticas públicas". 
Como observado por Roman (1991, p. 143-4), apud Przeworski (2006, p. 58): "se o controle social direto sobre os "serviços de interesse público" é eficaz, pode pressionar os executores para que procurem ser mais eficientes e "derruba-los, caso as queixas acumuladas gerem decisões de autoridades que fazem a supervisão ou a auditoria, e depois dos que fiscalizam os serviços públicos".

Sendo assim, percebe-se que a transparência pública é um instrumento de fomento para o controle social, em que os gestores públicos ao divulgarem seus atos de gestão, de forma completa e inteligível, permitem que a sociedade tenha um maior poder de fiscalização sobre os atos públicos, com possíveis induções a comportamentos participativos quanto às decisões sobre políticas públicas e melhoria no desempenho do setor público.

Dessa forma, segundo Diniz (1995), apud Ferreira (2006, p. 14), controle social é denominado de accountability pela ciência política, podendo ser considerado a obrigação da prestação de contas do poder público perante a sociedade civil e às autoridades competentes. Ele se traduz pela existência de mecanismos de cobrança e de controles que constituem fator favorável ao êxito da gestão pública, permitindo evitar a apropriação da máquina por interesses privados, o desperdício, além da alocação de recursos para fins não previstos.

O conceito de accountability pressupõe duas partes: uma que delega a responsabilidade e a outra que é a responsável por gerir os recursos. Concomitantemente, cria-se a obrigação de prestação de contas por parte de quem administra os recursos, que deverá demonstrar através dos resultados obtidos a boa aplicação dos recursos.

O’Donnel (1999), apud Ferreira (2006, p. 4), fala em três tipos de accountability: a accountability horizontal, a accountability vertical eleitoral (Electoral Vertical Accountability) e a accountability societal vertical (Vertical Societal Accountability), os quais estão representados na Figura 9, a seguir. 


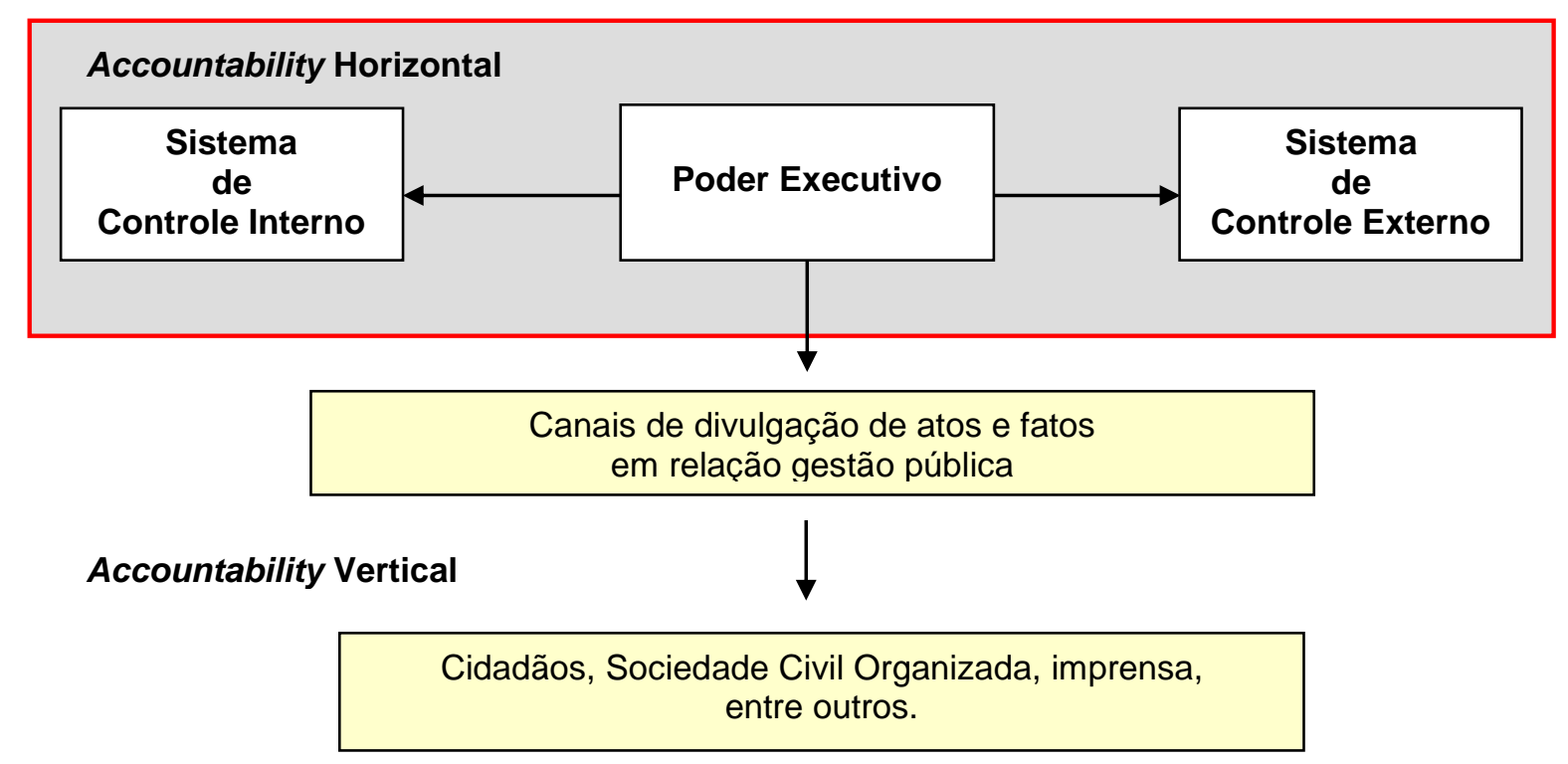

Figura 9 - Dimensões de Accountability segundo O'Donnell.

Fonte: Elaborado pelo autor.

Accountability horizontal caracteriza-se pela atuação fiscalizatória e punitiva entre os poderes, ou atribuição legal a determinados órgãos internos para realizar essas funções. Temos para a primeira situação, o sistema de controle externo representados pelo Congresso Nacional, Câmaras e Assembleias legislativas, auxiliadas pelos seus respectivos tribunais de contas. Quanto à segunda situação, temos o sistema de controle interno, cuja atuação do Ministério Público, das Controladorias ou Auditorias Gerais, Agências fiscalizadoras e Ouvidorias públicas. Ambos os sistemas de controle têm por finalidades a supervisão, recomendação de melhorias na gestão e na punição de ações ou omissões do Estado e de seus agentes, consideradas ilegais.

Por sua vez, O'Donnell (1999) apud Ferreira (2006) usa o conceito de accountability vertical para referir-se à vigilância e sanções que eleitores e outras organizações da sociedade civil exercem sobre os agentes estatais. Controle associado ao poder de punição ou reafirmação do eleitorado quanto aos representantes do povo. Ou seja, controle vinculado à elegibilidade ativa do cidadão. É o meio disponível para que cidadãos possam atuar na fiscalização da atividade pública dos seus representantes. 
O terceiro tipo é o accountability social (ou societal), que não está ligado ao cidadão e ao voto, mas ligado às diversas entidades sociais como associações, sindicatos, sociedade civil organizada, mídia, etc, que investigam e denunciam abusos cometidos, e cobram responsabilização.

Dessa forma, a transparência governamental é um importante mecanismo função de subsidiar os controles descritos em vista de monitoramento de forma constante sobre a gestão dos recursos, com a função de evitar desvios que acarretem danos ao erário ocasionados, e, por sua vez, permitir maior participação popular na gestão dos recursos públicos.

No entanto, uma das condições para que o controle da sociedade (accountability vertical: Eleitoral e Societal) possa ser acionado, e a existência de uma política estatal de divulgação efetiva dos dados sobre a gestão pública, com clareza e integridade informacional.

Quanto à divulgação das contas públicas a Lei Complementar ํo 131 introduziu um importante dispositivo para fomentar a divulgação da gestão das determinando a implementação de Portais da Transparência em todos os níveis de governo.

Soma-se a essa iniciativa a publicação da Lei Federal $n^{\circ}$ 12.527, de 18 de novembro de 2011 (Lei de Acesso a Informação - LAl), além de reforçar a obrigatoriedade da administração pública em disponibilizar informações públicas, introduz critérios mínimos para que isso ocorra, tal como disposto no artigo $5^{\circ}$.

Art. 5o É dever do Estado garantir o direito de acesso à informação, que será franqueada, mediante procedimentos objetivos e ágeis, de forma transparente, clara e em linguagem de fácil compreensão.

Dessa forma, a sociedade dispõe de instrumentos robustos para 0 conhecimento necessário sobre a gestão da coisa pública, como ferramenta avaliativa sobre o desempenho dos gestores públicos e a possibilidade de maior participação na formulação e implementação das políticas públicas.

Trazendo o tema para as transferências voluntárias da União, a transparência sobre o processo de repasses de recursos da União para estados, municípios e organizações da sociedade civil organizada torna-se relevante na medida em que as execuções descentralizadas de recursos do orçamento fiscal e da seguridade social permaneçam como estratégia de execução de parte das políticas públicas da União. 
A pulverização de recursos para os diversos estados, municípios e organizações privadas sem fins lucrativos e a intenção de redistribuição tributária por meio das transferências voluntárias torna o acompanhamento da execução de tais recursos complexa, tanto para o setor público quanto para a sociedade.

Segundo Rezende (2011, p. 342) a eficiência na alocação dos recursos requer controle permanente da sociedade sobre o Estado e quanto menor for sua contribuição direta para o orçamento estadual e municipal, maior será, portanto o risco de ineficiência e desperdícios. 


\section{METODOLOGIA}

A presente pesquisa descritiva refere-se a estudo sobre as transferências voluntárias da União, sendo utilizadas duas formas de análise.

A primeira de natureza quantitativa buscou-se com base nos dados disponibilizados no extrator do Sistema de Gestão de Convênios e Contratos de Repasses - SICONV evidenciar as características dos repasses de recursos voluntários aos entes subnacionais e entidades privadas sem fins lucrativos e à definição dos problemas apresentados nos itens 4.1.1 - Atrasos na execução, 4.1.2 - Devolução dos recursos, 4.1.3 - Perda do poder de compra dos recursos transferidos e 4.1.4 - Redução do poder de compra dos recursos transferidos.

Para permitir essa análise realizou-se um tratamento prévio em relação aos dados primários da base do Sistema Siconv, disponíveis no endereço eletrônico https://portal.convenios.gov.br/informacoes-gerenciais, a fim de torná-los mais expressivos.

Para a apuração dos dados, foram utilizados recursos informatizados do pacote Microsoft Office. Inicialmente foram realizadas exclusões das repetições de registros e informações incompletas que afetariam na análise. Dessa forma, passamos de 114.905 para a análise de 89.259 registros. Redução de 25.646 registros.

Posteriormente, foi realizada a tabulação dos dados considerando as informações por acordos, conforme os atributos dispostos no Quadro 10, a seguir.

Quadro 10 - Relação de dados necessários para análise.

\begin{tabular}{|c|c|}
\hline 1 & Ano do Convênio \\
\hline 2 & Número de registro do convênio \\
\hline 3 & Situação do Convênio \\
\hline 4 & Esfera Administrativa do Proponente \\
\hline 5 & Unidade Federativa do Proponente \\
\hline 6 & Período de Vigência \\
\hline 7 & Valor Global \\
\hline 8 & Valor do Repasse \\
\hline 9 & Valor da Contrapartida \\
\hline 10 & Valor empenhado \\
\hline 11 & Valor desembolsado \\
\hline
\end{tabular}

Fonte: Elaborado pelo autor. 
A partir da organização dos dados, foram elaboradas "Tabelas Dinâmicas", disponível na ferramenta Excel do pacote Office, no intuito de fazer contagens, agrupamentos, vinculações e cruzamentos dos dados disponíveis, permitindo assim a condensação, a análise e interpretações do fenômeno observável, e, a partir disso, identificar alguns fatos na execução dos acordos firmados entre a União, estados, municípios, consórcios públicos e organizações privadas sem fins lucrativos.

Nessa primeira fase da análise é reconhecida a possível perda de detalhes no processo de tratamento de dados, uma vez que se trata de sintetização.

Para a análise de natureza qualitativa, um questionário padronizado foi elaborado (Apêndice E) a partir do referencial teórico, sendo composto por 52 perguntas, estruturado com escalas de 0 a 10, categorizadas em 3 grandes tópicos: Planejamento orçamentário, gestão e controle, as quais foram direcionadas aos grupos focais: gestores públicos municipais e distritais que lidam com recursos de transferências voluntárias do orçamento fiscal e da seguridade social da União.

A uniformização do questionário, segundo Laville e Dionne (1999, p. 184) assegura que cada pessoa veja as questões formuladas da mesma maneira, na mesma ordem e acompanhadas da mesma opção de respostas, o que facilita a compilação e a comparação das respostas escolhidas e permite recorre ao aparelho estatístico quando chega o memento de análise.

Em relação à decisão em se direcionar os questionários aos gestores municipais e distritais foi motivada pela hipótese de que ao estarem mais próximos da população local, estes poderiam prestar um melhor serviço. Sendo assim, estariam mais propensas a uma maior interação com os órgãos da União na formatação das parcerias de recursos voluntários.

Quanto as escalas do questionário tais foram agrupadas em 4 níveis de observação: (0) - Não se aplica/nenhuma/péssimo; (1 a 3) - Aplica-se pouco/baixo/ruim; (4 a 7) - Sim, em parte/médio/bom; (8 a 10) - Sim, totalmente/fácil/ótimo.

O survey foi aplicado a um grupo de discussão on line relativo às transferências voluntarias da União, durante o mês de maio de 2016, por meio de formulário eletrônico, junto com a carta de apresentação da pesquisa, no qual participam gestores públicos e privados que lidam com tal recurso federal.

$\mathrm{Na}$ aplicação do survey obtivemos a resposta de 75 servidores, sendo 13 Distritais e 62 municipais. 
Nesta pesquisa optou-se por incluir o Distrito Federal nas respostas municipais em vista de identificar possíveis gap ocasionados por questões relacionadas ao distanciamento geográfico entre as municipalidades e o poder central. Haja vista que a Administração pública distrital compartilha a mesma base geográfica da Administração Pública Federal.

A partir das respostas, os dados foram agrupados e realizados cruzamentos entre possíveis correlações e realizadas análises descritivas das respostas municipais com a dos gestores distritais.

Quadro 11 - Questões relacionadas para o teste de significância.

\begin{tabular}{|c|c|}
\hline $\mathrm{a} 1 ; \mathrm{b} 1$ & $\mathrm{e} 1 ; \mathrm{f} 3$ \\
\hline $\mathrm{a} 2 ; \mathrm{b} 2$ & $\mathrm{e} 2 ; \mathrm{f} 3$ \\
\hline $\mathrm{a} 3 ; \mathrm{b} 3$ & $\mathrm{e} 4 ; \mathrm{e} 7$ \\
\hline $\mathrm{a} 4 ; \mathrm{b} 4$ & $\mathrm{e} 5 ; \mathrm{e} 6$ \\
\hline $\mathrm{a} 5 ; \mathrm{b} 5$ & $\mathrm{e} 5 ; \mathrm{e} 7$ \\
\hline $\mathrm{a} 6 ; \mathrm{b} 6$ & $\mathrm{fi} ; 4$ \\
\hline $\mathrm{c} 1 ; \mathrm{c3}$ & $\mathrm{f} 2 ; \mathrm{f} 4$ \\
\hline $\mathrm{c} 2 ; \mathrm{d} 3$ & $\mathrm{~g} 1 ; \mathrm{g} 6$ \\
\hline $\mathrm{c} 4 ; \mathrm{c5}$ & $\mathrm{g} 2 ; \mathrm{g} 7$ \\
\hline $\mathrm{c} 6 ; \mathrm{d} 5$ & $\mathrm{~g} 3 ; \mathrm{g} 5$ \\
\hline $\mathrm{c} 8 ; \mathrm{d} 4$ & $\mathrm{~g} 5 ; \mathrm{h} 3$ \\
\hline $\mathrm{d} 1 ; \mathrm{d} 4$ & $\mathrm{~g} 6 ; \mathrm{h} 4$ \\
\hline $\mathrm{d} 6 ; \mathrm{g} 4$ & $\mathrm{~g} 7 ; \mathrm{h} 5$ \\
\hline
\end{tabular}

Fonte: Elaborado pelo autor.

Porém, em oito questões não foi possível relacionar com outras questões (c7, d2, d7, e3, f5, g4, h1 e h2). Sendo assim, foram realizadas analises diretas entre as respostas dos gestores municipais com as dos distritais.

Com a finalidade de comparar o nível de associação entre Os itens entre os gestores do Distrito Federal e os gestores municipais, todas as correlações foram realizadas separadamente entre esses dois grupos.

Em relação aos testes estatísticos, a metodologia empregada buscou verificar se há diferença entre as médias populacionais das variáveis que correspondem às respostas dos gestores distritais e municipais, quanto às percepções de planejamento, gestão e controle sobre as transferências voluntária da União. Se 
houver diferença entre estas médias pode-se inferir que há um comportamento distinto na percepção entre os dois grupos de gestores.

Além disso, foi realizada análise de correlação para verificar o grau de relacionamento entre as variáveis do questionário, ou seja, se existem comportamentos relacionados na população comprovados ou não por meio dos testes de hipóteses estatísticos.

Em estatística, o teste de hipóteses é o método utilizado para verificar se os dados são compatíveis com alguma hipótese, podendo muitas vezes sugerir a nãovalidade de uma hipótese. Ele é baseado na análise de uma amostra, através da teoria de probabilidades, usado para avaliar determinados parâmetros que são desconhecidos numa população. Na maioria das vezes é constituído por duas hipóteses:

Hipótese nula $\left(\mathrm{H}_{0}\right)$ : Hipótese a ser testada

Hipótese alternativa $\left(\mathrm{H}_{1}\right)$ : Hipótese aceitável caso a nula seja rejeitada

Quanto Nível de significância ( $\alpha$ ), é a probabilidade com a qual se sujeita a correr o risco de um Erro do Tipo I (erro de rejeitar uma hipótese dada que ela é verdadeira). Costuma ser identificado pela letra grega a e é determinado antes da extração da amostra. Por exemplo, se usarmos o nível de significância igual a 0,05 significa que tem se a probabilidade de 5 em 100 de que a hipótese seja rejeitada quando deveria ser aceita, isto é, $95 \%$ de chance de ter tomado uma decisão acertada.

Na estatística clássica, o valor-p, p-value ou nível descritivo, é uma estatística utilizada para sintetizar o resultado de um teste de hipóteses. Formalmente, o valor$p$ é definido como a probabilidade de se obter uma estatística de teste igual ou mais extrema que aquela observada em uma amostra, assumindo verdadeira a hipótese nula. Se o p-valor for menor do que o nível de significância estabelecido, rejeita-se a hipótese nula. Caso contrário, não se rejeita $H_{0}$, sendo aceitável a probabilidade de que seja verdadeira.

Para verificar a diferença entre as médias, há uma gama de testes possíveis a serem utilizados. Os mais adequados ao desenho desta pesquisa são os testes TStudent e Mann-Whitney. A diferença entre eles está no fato de assumirmos ou não 
como verdadeira a hipótese de normalidade dos dados. Deste modo, estas opções se diferenciam por um ser um teste paramétrico e outro ser um teste nãoparamétrico, respectivamente.

O fator determinante para o uso de um ou outro é a normalidade dos dados apresentados, que é verificada por dois testes: Kolmogorov-Smirnov e Shapiro-Wilk. Para a realização do teste de comparação de médias paramétrico (T-Student), os dados dos dois grupos (gestores do DF e de outras localidades) devem ter a hipótese de normalidade aceita. Caso contrário, o teste de não-paramétrico (MannWhitney) é utilizado, pois ele não precisa que esta hipótese seja satisfeita.

Por fim, em relação à análise de correlação, há também duas possibilidades de testes: a realização de um teste paramétrico utilizando como base a correlação linear de Pearson ou a realização de um teste não-paramétrico utilizando com base a correlação de postos de Spearman. Para que o teste paramétrico seja utilizado os dados das duas variáveis comparadas devem ser possuir distribuição Normal de probabilidade. Caso contrário, segue-se para a alternativa não-paramétrica, o teste de correlação de Spearman.

Todas as análises foram realizadas utilizando o software IBM SPSS Statistics, versão 22. 


\section{RESULTADOS}

\subsection{Análise quantitativa: características gerais e específicas dos repasses voluntários da União}

A execução das políticas públicas, constantes no orçamento fiscal e da seguridade social da União, por parte dos entes subnacionais e entidades privadas sem fins lucrativos não é algo recente. Podemos afirmar esse fato com base na legislação sobre o assunto.

$\mathrm{Na}$ reforma empreendida pelo Decreto Lei $n^{\circ} 200 / 67$ já se mencionava a intenção da administração pública federal em executar projetos e atividades do orçamento Federal de forma "amplamente descentralizada", conforme estabelecido pelo art. 10, do referido Decreto-Lei.

Art. 10. A execução das atividades da Administração Federal deverá ser amplamente descentralizada.

$\S 1^{\circ}$ A descentralização será posta em prática em três planos principais:

a) dentro dos quadros da Administração Federal, distinguindo-se claramente o nível de direção do de execução;

b) da Administração Federal para a das unidades federadas, quando estejam devidamente aparelhadas e mediante convênio;

c) da Administração Federal para a órbita privada, mediante contratos ou concessões. (Grifos Nossos)

A parceria entre a União e os entes subnacionais também está presente no Decreto Federal $n^{\circ}$ 93.892/86, que em seu art. 48 explicita, in verbis:

os serviços de interesses recíprocos dos órgãos e entidades da administração pública federal e de outras entidades públicas ou organizações particulares poderão ser executadas sob o regime de mútua cooperação, mediante convênios, acordos ou ajuste.

Posterior a Constituição de 1988, foram instituídos outros dispositivos para regrar as parcerias para a execução de objetos de políticas públicas de interesses recíprocos entre União, estados, munícipios, Distrito Federal e entidades privadas sem fins lucrativos, dentre eles estão a Lei Complementar (LC) ํo 101/2000 (Art. 25), Decreto ํㅜ 6.170/2007 e Portaria Interministerial CGUMFMP nํ507/2011. 
Para o caso de transferências de recursos para estados e municípios, o art. 25 da LC n 101/2000 define como transferências voluntárias "a entrega de recursos correntes ou de capital a outro ente da federação, a título de cooperação, auxílio ou assistência financeira, que não decorra de determinação constitucional, legal ou destinado ao Sistema Único de Saúde".

Atualmente as parcerias entre entes federados são formalizadas por meio de convênios e contratos de repasses.

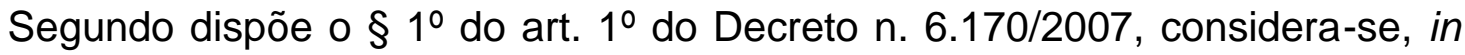
verbis:

\begin{abstract}
Art. $1^{\circ}[\ldots]$.
$\S 1$ Para os efeitos deste Decreto, considera-se:

I - convênio - acordo, ajuste ou qualquer outro instrumento que discipline a transferência de recursos financeiros de dotações consignadas nos Orçamentos Fiscal e da Seguridade Social da União e tenha como partícipe, de um lado, órgão ou entidade da administração pública federal, direta ou indireta, e, de outro lado, órgão ou entidade da administração pública estadual, distrital ou municipal, direta ou indireta, ou ainda, entidades privadas sem fins lucrativos, visando a execução de programa de governo, envolvendo a realização de projeto, atividade, serviço, aquisição de bens ou evento de interesse recíproco, em regime de mútua cooperação;

II - contrato de repasse - instrumento administrativo, de interesse recíproco, por meio do qual a transferência dos recursos financeiros se processa por intermédio de instituição ou agente financeiro público federal, que atua como mandatário da União. (Redação dada pelo Decreto n. 8.180, de 2013) $[\ldots]$.
\end{abstract}

Em relação às parcerias entre o setor público e o privado sem fins lucrativos, para a consecução de finalidades de interesse público, são formalizadas por meio de termos de fomento ou em acordos de cooperação, regrada pela Lei no 13.019/2014.

Para gerir tais acordos, os órgãos da União tem a disposição uma ferramenta de tecnologia da informação, desenvolvida pelo Ministério do Planejamento, Orçamento e Gestão (MP), e instituída por força do art. 13 do Decreto № 6.170/2007, denominada de Sistema de Gestão de Convênios e Contratos de Repasses SICONV, o qual tem a função de registrar os atos quanto à celebração, à liberação de recursos, o acompanhamento da execução e à prestação de contas de convênios, contratos de repasse e termos de fomento ou acordos de cooperação.

Por meio do extrator de dados desse Sistema, disponível no endereço https://portal.convenios.gov.br/informacoes-gerenciais, foi possível observar algumas características das transferências de recursos financeiros da União às entidades subnacionais e privadas sem fins lucrativos, as quais são descritas a seguir. 


\subsubsection{Características nos repasses de recursos de transferências voluntárias da União}

A União no período de 2008 a 2015, conforme demonstrado na Tabela 2, pactuou com estados, municípios, Distrito Federal e entidades privadas sem fins lucrativos a quantidade de 97.311 acordos, com o repasse de recursos federais em torno de $\mathrm{R} \$ 71,474$ bilhões, alocados no Orçamento Fiscal e da Seguridade Social da União, num volume total de $\mathrm{R} \$ 80,259$ bilhões (valor de repasse + contrapartida do parceiro público ou privado) ${ }^{21}$ a ser aplicado em projetos e atividades específicos.

Tabela 2 - Volume de recursos de transferências voluntárias da União - Período 2008-março de 2015 - em R $\$$.

\begin{tabular}{ccccc}
\hline \multirow{2}{*}{ Ano } & Quantidade & \multicolumn{3}{c}{ Valor } \\
\cline { 3 - 5 } & & Repasse & Contrapartida & Global \\
\hline 2008 & 2.290 & 2.435 .629 .148 & 414.946 .030 & 2.869 .222 .900 \\
2009 & 20.687 & 11.121 .180 .706 & 1.763 .739 .649 & 12.952 .752 .355 \\
2010 & 19.853 & 10.541 .516 .083 & 1.282 .470 .478 & 11.885 .232 .425 \\
2011 & 11.397 & 9.307 .921 .443 & 1.313 .456 .458 & 10.658 .426 .211 \\
2012 & 9.763 & 11.309 .864 .576 & 1.279 .905 .205 & 12.656 .669 .316 \\
2013 & 14.736 & 15.159 .397 .199 & 1.841 .464 .490 & 17.026 .662 .709 \\
2014 & 10.973 & 6.308 .664 .842 & 404.630 .191 & 6.716 .796 .067 \\
2015 & 7.612 & 5.289 .828 .770 & 204.205 .104 & 5.494 .068 .201 \\
Total & 97.311 & 71.474 .002 .767 & 8.504 .817 .605 & 80.259 .830 .184 \\
\hline
\end{tabular}

Fonte: Adaptado de Siconv (2016).

Com base no Gráfico 1, observa-se que em referência a quantidade de acordos, há uma predominância dos órgãos da União em fazê-los com os órgãos da administração direta municipais. Ou seja, do total de 97.311 , cerca de $76 \%$ foram pactuadas com as administrações municipais, em detrimento as administrações estaduais, Distrital, consórcios públicos, empresas públicas e entidades privadas sem fins lucrativos.

\footnotetext{
${ }^{21}$ A Lei de Diretrizes Orçamentárias da União atualmente vem incluindo em seu texto dispositivo que torna uma condição a contraparte financeira do parceiro público. E para as entidades privadas sem fins lucrativos uma faculdade.
} 


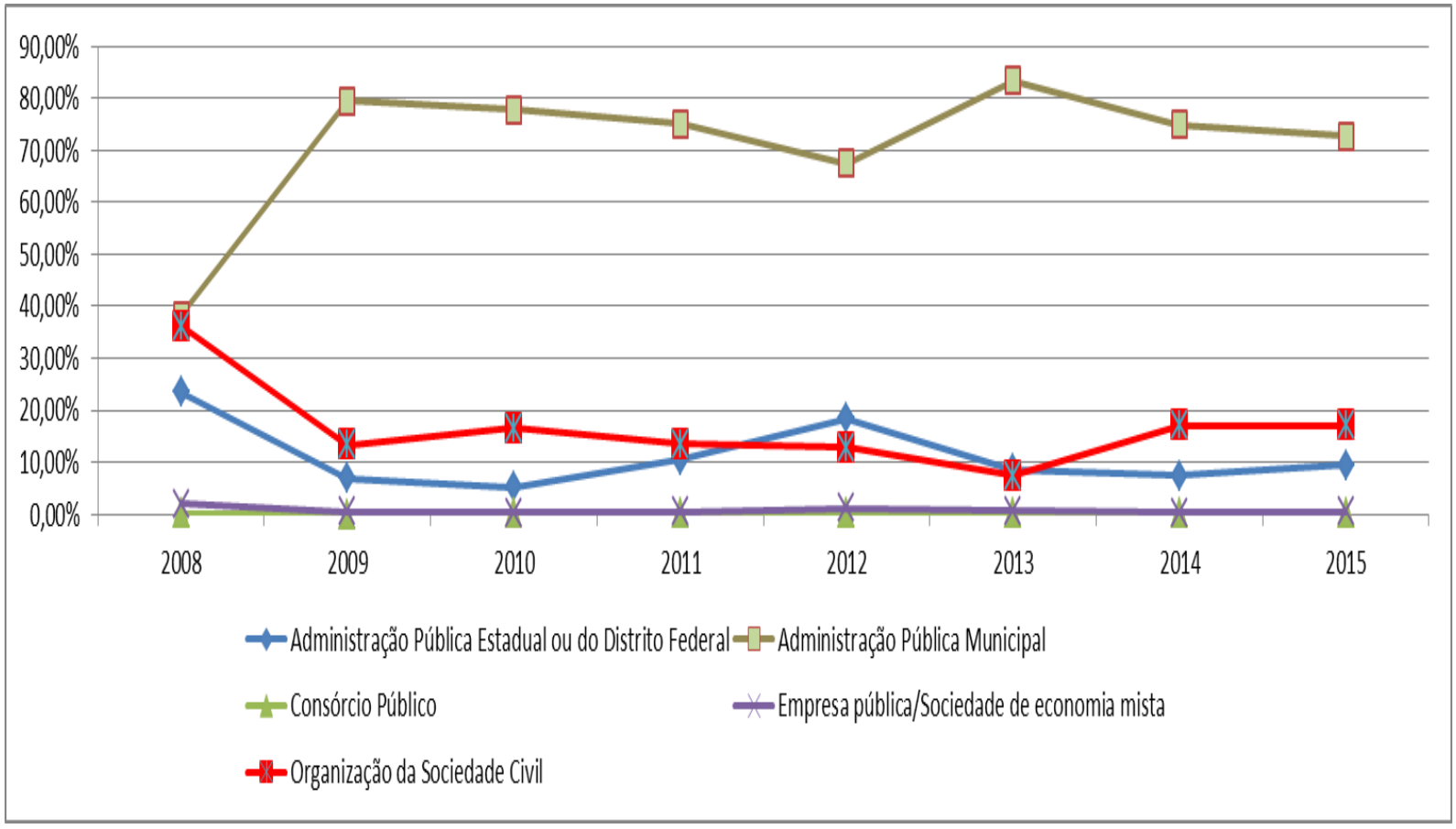

Gráfico 1 - Percentual de participação na captação de recursos - quantidade.

Fonte: Adpatdo de Siconv (2016).

Em relação à disponibilidade financeira, também observamos essa tendência no direcionamento desses recursos para as diversas prefeituras brasileiras. Conforme demonstrado na Tabela A (Apêndice A) foram transferidos as administrações públicas municipais $46,07 \%$ do total dos recursos financeiros colocados à disposição pela União; seguidos de $30,60 \%$ de transferências às administrações públicas estaduais e do Distrito Federal; 20,42\% para as organizações da sociedade civil; $2,11 \%$ para empresas públicas e sociedade de economia mista dos diversos estados; e somente $0,81 \%$ direcionados aos consórcios públicos.

Ao apresentarmos os dados da Tabela A no formato do Gráfico 2, observamos essa tendência da União em de formalizar os acordos com as administrações municipais. 

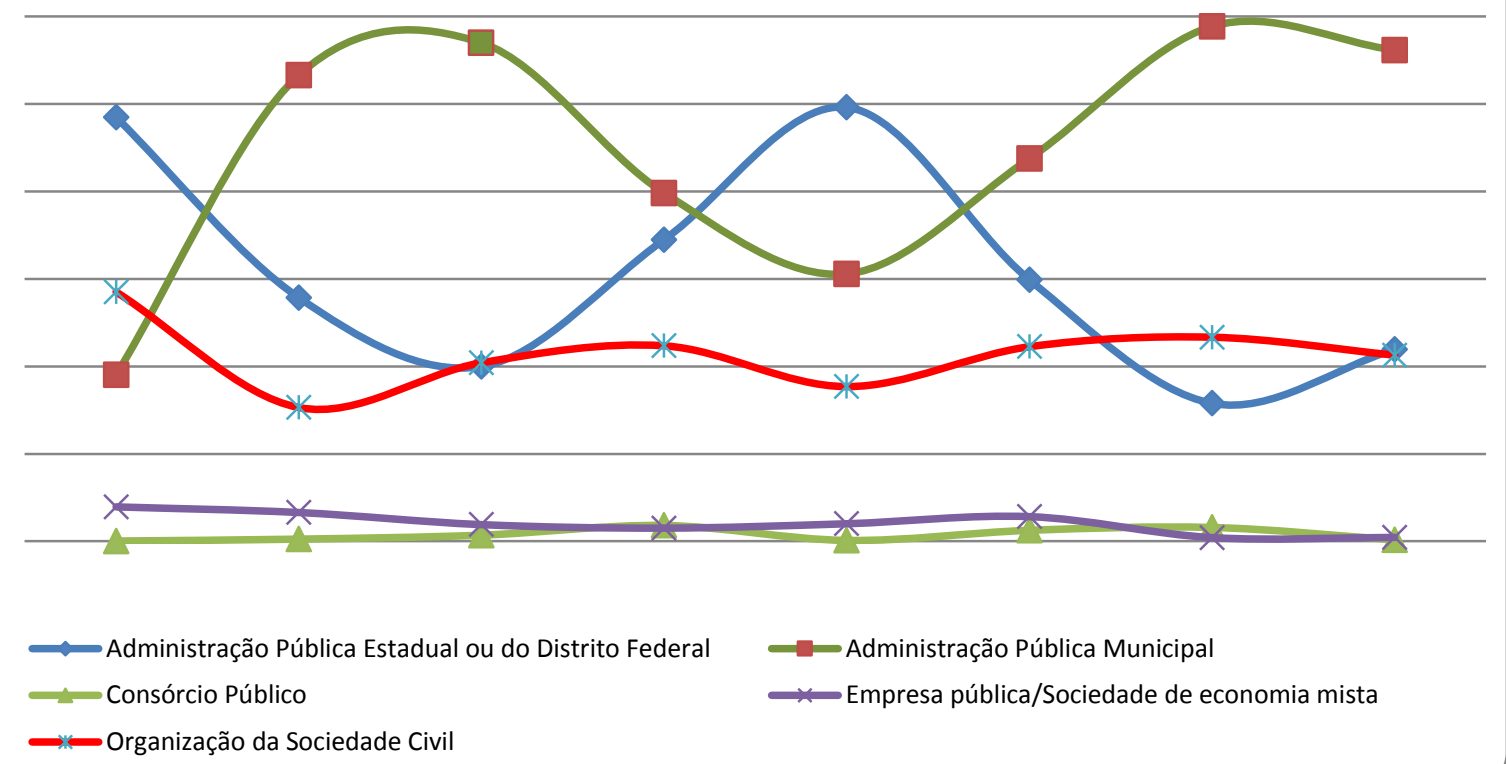

Gráfico 2 - Percentuais de participação nas transferências voluntárias da União - recursos financeiros por natureza jurídica - período 2008-2015.

Fonte: Adpatdo de Siconv (2016).

Gráfico que também demonstra as variações dos repasses financeiros aos estados e aos municípios de forma oposta, durante o período de 2008 a 2015. Período o qual coincide com as eleições gerais (anos: 2010 e 2014) e municipais (anos: 2008 e 2012).

De acordo com o art. 73, inciso I, alínea "a", da Lei 9.504, de 30 de setembro de 1997, a qual estabelece normas sobre eleições, é proibido aos agentes públicos, servidores ou não, nos três meses que antecedem o pleito eleitoral, realizar transferências voluntarias de recursos da união a estados e municípios, e dos estados a municípios, sob pena de nulidade do pleito, ressalvados os recursos destinados a cumprir obrigação forma preexistente, para execução de obra ou serviço em andamento e com cronograma prefixado, e aos destinados a atender a situações de emergência e de calamidade pública (PEREIRA JUNIOR e DOTTI, 2013). 
Diante desse apontamento, uma linha de pesquisa sobre esse fenômeno seria a verificação da interferência da Lei Eleitoral no 9.504/199722 sobre os repasses de recursos da União aos estados e municípios. No entanto, tal fato não será objeto desta pesquisa.

Em relação aos repasses de recursos por faixa de valor (Tabela B - Apêndice B) observamos o predomínio dos repasses de recursos para acordos situados entre 100 a 500 mil reais, no período de 2008 a 2015. Dos 97.664 acordos no período de 2008 a 2015, 68.186 se situaram nessa faixa de valor. Ou seja, 70\% dos acordos estão relacionados a projetos e atividades de valores inferiores a $R \$ 500$ mil reais.

Considerando a repartição dos acordos por região (Tabela 3), agora em relação ao período de 2008 a 2016 (março), observamos que há uma maior participação da região Nordeste, no que registrou 25.455 acordos, com valor em torno de $\mathrm{R} \$ 27,716$ bilhões; em segundo a região Sudeste, com 28.302 acordos, superior em 11,18\% em relação à região Nordeste, porém com um valor menor de $\mathrm{R} \$ 22,062$ bilhões, ou seja, 25,62\% inferior à região Nordeste. Para a região Sul tivemos o registro de 25.612 acordos, com o repasse de recursos em torno de $R \$$ 12,472 bilhões. Para a região Centro-Oeste registrou-se 9.008 acordos, representando o valor aproximado de $\mathrm{R} \$ 9,413$ bilhões. Por último, na região Norte foi registrado 9.297 em acordos firmados, na soma por volta de $\mathrm{R} \$ 8,842$ bilhões.

Tabela 3 - Quantidade e valor regionalizado - repasses a Entidades Públicas e Privadas sem fins lucrativos - período 2008-2016 - em R\$.

\begin{tabular}{lccc}
\hline \multicolumn{1}{c}{ Região } & Quantidade & Valor Global & Valor de Repasse \\
\hline NORTE & 9.297 & $8.842 .069 .578,19$ & $8.108 .202 .046,26$ \\
CENTRO-OESTE & 9.008 & $9.413 .529 .542,30$ & $8.533 .955 .890,44$ \\
SUL & 25.612 & $12.472 .956 .060,52$ & $11.000 .154 .888,75$ \\
SUDESTE & 28.302 & $22.062 .554 .796,99$ & $19.131 .947 .317,16$ \\
NORDESTE & 25.445 & $27.716 .889 .162,94$ & $24.954 .584 .053,03$ \\
Total & 97.664 & $80.507 .999 .140,94$ & $71.728 .844 .195,64$ \\
\hline
\end{tabular}

Fonte: Adpatdo de Siconv (2016).

Detalhado os repasses por unidade federativa, segundo demonstrado na Tabela 4, observamos a predominância dos Estados da região Sudeste entre os seis

22 Eleições intercaladas para Presidente da República, Governadores de Estados e Deputados Federais e Distritais em relação às eleições para os representantes municipais, cada uma com um ciclo de 4 anos. 
estados que mais receberam recursos de transferências voluntárias da União, no período de 2008 a 2016 (Março).

Os Estados de São Paulo, Minas Gerais e Rio de Janeiro tiveram disponível, a quantia em torno de $R \$ 8,088$ bilhões, $R \$ 5,660$ bilhões e $R \$ 4,321$ bilhões, respectivamente, perfazendo um total aproximado de $R \$ 18,069$ bilhões, no que representa cerca de $25,20 \%$ do total de recursos financeiros repassado pela União.

No entanto, considerando o valor per capita, verifica-se que essas Unidades Federativas estão classificadas entre as seis unidades federativas com o menor índice de recebimento de recursos de transferências voluntárias da União, conforme demonstrado na Tabela 4 e no Gráfico 3, a seguir. 
Tabela 4 - Valor per capita por Unidade Federativa - repasses a Entidades Públicas e Privadas sem fins lucrativos - período 2008-2016 - em R\$.

\begin{tabular}{|c|c|c|c|c|c|}
\hline UF & População & $\begin{array}{l}\text { Quantidade } \\
\text { de Acordos }\end{array}$ & Valor Global & Valor Repasse & $\begin{array}{c}\text { Valor Per } \\
\text { Capita } \\
\text { (Repasse) }\end{array}$ \\
\hline AP & 781.097 & 731 & $676.512 .308,09$ & $621.301 .009,69$ & 795,42 \\
\hline RO & 1.785 .468 & 2.078 & $1.075 .194 .593,97$ & $998.798 .753,28$ & 559,40 \\
\hline$A C$ & 815.024 & 1.264 & $1.148 .380 .117,42$ & $1.060 .950 .711,46$ & $1.301,74$ \\
\hline ES & 3.964 .621 & 2.087 & $1.270 .082 .331,64$ & $1.062 .027 .712,82$ & 267,88 \\
\hline TO & 1.531 .043 & 1.897 & $1.259 .816 .337,05$ & 1.162.627.357,29 & 759,37 \\
\hline $\mathrm{RR}$ & 514.262 & 623 & $1.265 .671 .796,37$ & $1.189 .458 .705,70$ & $2.312,94$ \\
\hline SE & 2.263 .702 & 1.545 & $1.379 .580 .286,33$ & $1.225 .276 .049,82$ & 541,27 \\
\hline $\mathrm{RN}$ & 3.471 .966 & 2.590 & $1.567 .500 .395,54$ & $1.430 .404 .847,33$ & 411,99 \\
\hline PA & 8.257 .175 & 1.775 & $1.582 .760 .971,37$ & $1.443 .010 .740,34$ & 174,76 \\
\hline DF & 2.966 .458 & 1.203 & $1.697 .159 .567,94$ & $1.458 .952 .485,78$ & 491,82 \\
\hline $\mathrm{PI}$ & 3.212 .064 & 2.273 & $1.751 .408 .925,51$ & $1.625 .835 .656,32$ & 506,17 \\
\hline AM & 3.993 .840 & 929 & $1.833 .733 .453,92$ & $1.632 .054 .768,50$ & 408,64 \\
\hline MT & 3.330 .454 & 1.921 & $1.918 .370 .844,22$ & $1.696 .477 .409,13$ & 509,38 \\
\hline$A L$ & 3.356 .792 & 1.589 & $1.976 .014 .510,08$ & $1.799 .592 .186,41$ & 536,10 \\
\hline PB & 3.994 .453 & 2.598 & $2.191 .256 .620,09$ & $1.954 .259 .452,04$ & 489,24 \\
\hline MA & 6.943 .571 & 2.292 & 2.098.694.610,33 & $1.959 .062 .373,89$ & 282,14 \\
\hline GO & 6.686 .802 & 3.730 & $2.309 .631 .176,08$ & 2.112.620.636,34 & 315,94 \\
\hline SC & 6.879 .154 & 5.449 & $2.603 .122 .567,94$ & $2.244 .430 .902,92$ & 326,27 \\
\hline MS & 2.679 .528 & 2.154 & $3.488 .367 .954,06$ & $3.265 .905 .359,19$ & $1.218,84$ \\
\hline PR & 11.238 .558 & 8.428 & 4.317.895.277,09 & $3.836 .617 .226,67$ & 341,38 \\
\hline CE & 8.962 .215 & 4.024 & $4.551 .884 .080,67$ & 3.969.130.347,54 & 442,87 \\
\hline RJ & 16.633 .244 & 3.432 & $4.791 .445 .905,70$ & 4.321.118.622,18 & 259,79 \\
\hline RS & 11.289 .319 & 11.735 & $5.551 .938 .215,49$ & $4.919 .106 .759,16$ & 435,73 \\
\hline BA & 15.268 .288 & 5.388 & $5.962 .838 .403,82$ & $5.470 .577 .327,61$ & 358,30 \\
\hline PE & 9.402 .572 & 3.146 & $6.237 .711 .330,57$ & $5.520 .445 .812,07$ & 587,12 \\
\hline$M G$ & 20.984 .224 & 9.569 & $6.349 .085 .448,70$ & $5.660 .165 .604,49$ & 269,73 \\
\hline SP & 44.730 .365 & 13.214 & $9.651 .941 .110,95$ & 8.088.635.377,67 & 180,83 \\
\hline Total & 205.936.259 & 97.664 & $80.507 .999 .140,94$ & 71.728.844.195,64 & 348,31 \\
\hline
\end{tabular}

Fonte: IBGE (2015) e SICONV (2016). 


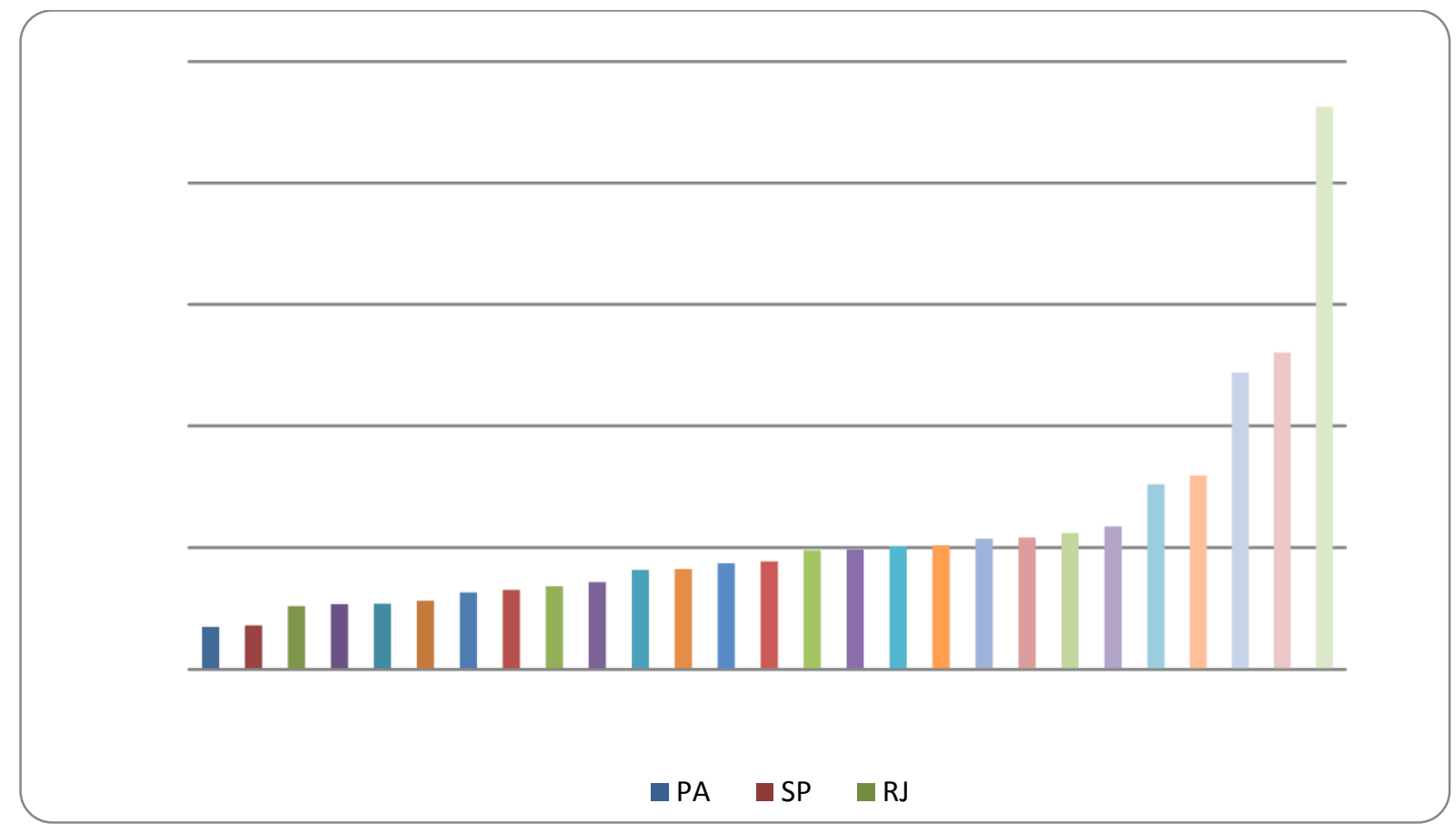

Gráfico 3 - Valor per capita por Unidade Federativa - repasses a Entidades Públicas e Privadas sem fins lucrativos - período 2008-março de 2016.

Fonte: Adaptado de Sicony (2016).

Apresentadas as características das repartições das transferências voluntárias, voltamo-nos para as questões criticas quanto à execução dos recursos transferidos, ainda com base nos dados disponíveis no Sistema Siconv.

\subsubsection{Atrasos na execução}

Para a formalização dos instrumentos para transferências voluntárias são necessários, dentre outros, constar os períodos de vigências para as consecuções dos objetos das políticas públicas a serem executadas.

Porém, a regulamentação dada pela PI № 507/2011 quanto à vigência é "pobre", assim como os termos que dispõe o Decreto $n^{\circ}$ 6.170/07. Dessa forma, em ambas as legislações que regem as transferências voluntárias, não constam a regulamentação dos prazos mínimos e máximos quanto à execução dos objetivos de interesses mútuos da União e seus participes.

Segundo dispõe o art. 43, inc. V, da Portaria interministerial n. 507/11, a vigência é determinada, por base apenas os cronogramas físicos, presentes nas metas estabelecidas nos planos de trabalho. 
Art. 43. São cláusulas necessárias nos instrumentos regulados por esta Portaria as que estabeleçam:

$\mathrm{V}$ - a vigência, fixada de acordo com o prazo previsto para a consecução do objeto e em função das metas estabelecidas;

Encontramos limitações de prazo segundo a legislação de orçamentação pública. Nos artigos n 67 e 68 do Decreto no 93.872/1986 estabelece prazos de vencimento de restos a pagar, no que os convênios e congêneres se enquadram na regra.

Caso os acordos não tenha cumprido os estágios de execução da despesa: empenho, liquidação e pagamento, no exercício financeiro a qual foi assinado os termos da parceira, poderá haver a execução em outro exercício, a depender se tais tiveram sido inscritas em restos a pagar. Ou seja, segundo o $\S 2^{\circ}$, do art. 68,

$\S 2$ o Os restos a pagar inscritos na condição de não processados e não liquidados posteriormente terão validade até 30 de junho do segundo ano subsequente ao de sua inscrição, ressalvado o disposto no § 3 ․ (Incluído pelo Decreto n. 7.654, de 2011)

Entende-se por restos a pagar, conforme preceitua o art. 67

(...) as despesas empenhadas e não pagas até 31 de dezembro, distinguindo-se as despesas processadas das não processadas.

$\S 1$ ํㅡㄹ Endem-se por processadas e não processadas, respectivamente, as despesas liquidadas e as não liquidadas, na forma prevista neste decreto.

Segundo dispõe $0 \S 2^{\circ}$ do art. 68, as despesas inscritas em restos a pagar não processados permanecem validas após 30 de junho do segundo ano subsequente ao de sua inscrição, cujas despesas sejam relacionadas à execução por transferências ou descentralização aos Estados, Distrito Federal e Municípios, desde que tenham algum início até a data de 30 de junho do ano subsequente à inscrição.

Por um lado, o não estabelecer de períodos mínimos e máximos deixa-se a critério dos setoriais de projetos dos órgãos estaduais, municipais e do Distrito Federal, assim como das organizações sem fins lucrativos a definição do período de execução. Por outro, permite-se o estabelecimento de prazos exíguos que impossibilitam a execução, em consideração ao grau de dificuldade de execução de cada projeto, tornado necessário ajustes de vigências por meio de termos aditivos 
com prazos dilatados, que ocasionam na morosidade na entrega dos objetos pactuados as populações de foco da política pública.

Segundo conclusão do Departamento de Consultoria, da Procuradoria-Geral Federal, da Advocacia-Geral da União (AGU), emitida no Parecer n. 03/2013 Câmara Permanente de Convênios:

[...] o objeto do convênio deverá ser executado dentro do prazo previsto inicialmente. Contudo, poderá ocorrer que esse prazo, por questões supervenientes, revela-se insuficiente, hipótese em que será possível a prorrogação do prazo de vigência, com base no art. 50 da PI n 507/2011. Considerando o regime aplicável a convênios, as limitações de prazo previstas nos incisos do art. 57 da Lei 8.666/93 não podem ser tidas como absolutas, sendo possível a prorrogação do prazo de vigência dos convênios em hipóteses diversas daquelas previstas no mencionado artigo, inclusive, em situações excepcionais, além do prazo de 60 (sessenta meses), desde que o caso concreto justifique tal excepcionalidade e sejam apresentadas as devidas justificativas técnicas suficientemente aptas a determinar a prorrogação do prazo".

O Parecer AGU, apesar de seu caráter sugestivo, induz a conclusão que os acordos de transferências voluntárias têm como regra a vigência de 60 meses, incluindo as possíveis prorrogações, sendo exceção àqueles que superem esse prazo.

Fato que, de forma indireta, alinha-se ao interesse dos gestores políticos ocupante de cargos de chefia do Poder executivo das três esferas políticas, que ao terem convênios firmados, os gestores têm o interesse de que sejam concluídos durante o seu mandato, e, assim, possam usufruir dos possíveis ganhos políticos derivados da entrega dos produtos dos planos de trabalhos acordados.

Diante dessa exposição, dados da Tabela C - Tempo Médio de Execução dos acordos vigentes (Apêndice $C$ ) demonstram que diversos acordos firmados por órgãos dos entes subnacionais e por organizações privadas sem fins lucrativos com a União têm prazo de vigência superior a 60 meses de execução (anos de 2008 a 2010). Ou seja, considerados apenas os acordos vigente, 4.746 estão com prazo de vigência superior a 5 anos de execução (acordos realizados nos anos de 2008, 2009 e 2010), cujos perfazem um valor global de 5,590 bilhões ${ }^{23}$ ainda não finalizados.

Detalhados esses acordos com vigência superior a 60 meses, por entidades jurídicas, verificamos conforme os dados das Tabelas $8,9,10,11$ e 12, para as

${ }^{23}$ Os dados disponíveis no sistema não permitiram a análise físico-financeira dos acordos, para possibilitar uma verificação do percentual de execução dos objetos dos planos de trabalhos. 
administrações municipais registrou-se a quantidade de 3.932, com o valor de global aproximado de $R \$ 3,226$ bilhões; para as administrações públicas estaduais e distrital observou-se a quantidade de 387 acordos, com o valor global de $R \$ 1,956$ bilhões; para as entidades privadas sem fins lucrativos, 391 acordos com valor correspondente a $\mathrm{R} \$ 610,43$ milhões; para as empresas públicas dos diversos entes federados, registrou-se 22 acordos, com o valor de $\mathrm{R} \$ 144,92$ milhões; e por último, os consórcios públicos entre diversos entes federados, com 14 acordos e repasse de $\mathrm{R} \$ 52,73$ milhões.

Ainda, conforme apresentado na Tabela 5 - Acordos vigentes, más sem registros de execução, do total de 39.827 acordos em situação de vigência, verificamos que 14.472 não tiveram o valor desembolsado pela União (cujos tem grande possibilidade da necessidade de ajustes de vigência). Dessa forma, o volume em torno de $R \$ 10,332$ bilhões em recursos (valor de repasse da União + contrapartida do convenente) não está sendo aplicado para atender ou solucionar as necessidades, identificadas como de interesses mútuos, das populações de foco das políticas públicas. 
Tabela 5 - Acordos vigentes sem registro de execução - todos os partícipes - em $R \$$.

\begin{tabular}{|c|c|c|c|c|c|c|}
\hline \multirow{2}{*}{ Ano } & \multirow{2}{*}{$\begin{array}{l}\text { Quantidade } \\
\text { de Acordos }\end{array}$} & \multirow{2}{*}{$\begin{array}{l}\text { Tempo Médio } \\
\text { de Vigência }\end{array}$} & \multirow{2}{*}{$\begin{array}{c}\text { DesvPad de } \\
\text { Tempo de Vigência }\end{array}$} & \multicolumn{3}{|c|}{ Valor } \\
\hline & & & & Repasse & Contrapartida & Global \\
\hline 2008 & 6 & 6,51 & 0,68 & $995.000,000$ & $174.698,59$ & $1.169 .698,59$ \\
\hline 2010 & 112 & 5,74 & 0,50 & $92.520 .443,02$ & $7.175 .167,38$ & $99.695 .610,40$ \\
\hline 2011 & 202 & 4,66 & 0,58 & $207.553 .519,20$ & $21.925 .370,75$ & $229.478 .889,95$ \\
\hline 2014 & 4.636 & 2,29 & 0,70 & $2.712 .735 .081,76$ & $169.768 .797,07$ & $2.882 .503 .878,83$ \\
\hline 2015 & 7.163 & 2,03 & 0,91 & $4.257 .177 .148,17$ & $168.929 .738,72$ & $4.428 .819 .924,17$ \\
\hline Total Geral & 14.472 & 2,34 & 1,02 & $9.653 .653 .927,05$ & $674.700 .447,78$ & $10.332 .120 .406,75$ \\
\hline
\end{tabular}

Fonte: Adaptado de Siconv (2016). 
No caso dos atrasos serem ocasionados pelos órgãos da União, devido ao não repasse dos recursos financeiros, há a determinação que os acordos afetados sejam prorrogados "de ofício", limitada a prorrogação ao exato período do atraso verificado (PI 507/11, inciso VI).

No entanto, independente da causa, os atrasos ocasionam a morosidade nos atendimentos das demandas de infraestrutura e sociais definidas nos planos de trabalhos dos acordos. Assim como, provocam num descasamento na efetivação do objeto do acordo com o mandato do agente político, sendo passível de ser denunciado ${ }^{24} \mathrm{o}$ acordo por parte do sucessor, devido à análise discricionária desse se o projeto ainda é necessário, ocasionando no destrato e no reembolso do recurso à União.

\subsubsection{Devolução de recursos}

Conforme Di Petro (2009, p. 235), se o conveniado recebe determinado valor, este fica vinculado ao objeto do convênio durante toda sua execução, razão pela qual o executor deve demonstrar que referido valor está sendo utilizado em consonância com os objetivos estipulados. Como não há comutatividade de valores, não basta demonstrar o resultado final obtido; é necessário demonstrar que todo o valor repassado foi utilizado na consecução daquele resultado.

Caso os resultados não sejam alcançados é dever da entidade receptora dos recursos federais a sua devolução a fonte de origem. Conforme definido na Portaria Interministerial o 507 (arts. 72 e 73) no caso de não ter ocorrido à execução física e financeira, os recursos transferidos deverão ser recolhidos à Conta Única do Tesouro da União (CTU).

Conforme dados da Tabela 6, verificamos que no período de 2008 a 2014⿻, 2.934 acordos tiveram a prestação de contas apresentadas a órgãos da União, por parte dos órgãos estaduais, municipais, distritais, empresas públicas e consórcios públicos dos diversos entes e das organizações sociais, cujos objetos pactuados não forma executados.

24 Título: DA DENÚNCIA E DA RESCISÃO, art. 80, da Portaria Interministerial 507/2011: O convênio poderá ser denunciado a qualquer tempo, ficando os partícipes responsáveis somente pelas obrigações e auferindo as vantagens do tempo em que participaram voluntariamente da avença, não sendo admissível cláusula obrigatória de permanência ou sancionadora dos denunciantes.

${ }^{25}$ Não utilizamos o ano de 2015, pois diversos acordos desse ano ainda estão dentro do período de vigência regular de 2,5 anos. 
O volume devolvido ou objetos dos acordos que não atingiram o planejado somam a quantia em torno de $\mathrm{R} \$ 2.498$ bilhões (repasse + contrapartida), representando $R \$ 2.213$ bilhões de recursos não utilizados e que ficaram indisponíveis para realocação em outros programas orçamentários durante o tempo médio de 1,9 anos.

Tabela 6 - Prestações de contas sem recursos executados - todos os partícipes - em R $\$$.

\begin{tabular}{|c|c|c|c|c|c|}
\hline \multirow{2}{*}{ Ano } & \multirow{2}{*}{$\begin{array}{l}\text { Quantidade } \\
\text { de Acordos }\end{array}$} & \multirow{2}{*}{$\begin{array}{l}\text { Média de } \\
\text { Tempo de } \\
\text { Vigência }\end{array}$} & \multicolumn{3}{|c|}{ Valor } \\
\hline & & & Repasse & Contrapartida & Global \\
\hline 2008 & 293 & 1,16 & $213.093 .172,05$ & $33.109 .187,08$ & $246.202 .359,13$ \\
\hline 2009 & 573 & 2,26 & $472.024 .762,00$ & $62.175 .443,19$ & $534.200 .205,19$ \\
\hline 2010 & 500 & 2,03 & $313.413 .685,99$ & $67.600 .939,99$ & $381.014 .625,98$ \\
\hline 2011 & 196 & 2,50 & $157.388 .465,23$ & $24.973 .996,74$ & $182.362 .461,97$ \\
\hline 2012 & 368 & 2,27 & $376.461 .543,77$ & $53.001 .317,52$ & $429.462 .861,29$ \\
\hline 2013 & 875 & 1,92 & $590.762 .417,34$ & $40.453 .258,98$ & $631.215 .676,32$ \\
\hline 2014 & 129 & 1,12 & $90.360 .912,73$ & $3.258 .860,33$ & $93.619 .773,06$ \\
\hline Total Geral & 2934 & 1,98 & $2.213 .504 .959,11$ & $284.573 .003,83$ & 2.498.077.962,94 \\
\hline
\end{tabular}

Fonte: Adaptado de SICONV (2016).

As administrações públicas diretas municipais foram as que tiveram mais registros de inexecuções e devoluções, ou seja, 2.004 acordos sem execução com a respectiva devolução à $C T U$ de $R \$ 1.033$ bilhões; seguidos das administrações públicas estaduais e distrital que devolveram cerca de $R \$ 843$ milhões a União, devido à inexecução de 498 acordos; em terceiro, as organizações civis de interesse público registraram 409 acordos sem execução, com a devolução de $R \$ 312$ milhões; em quarto, as empresas públicas dos diversos entes subnacionais devolveram a União em torno de $\mathrm{R} \$ 18,112$ milhões, em relação a 19 acordos sem registros de execução; por último, temos os consórcios públicos, com respectivamente 4 acordos e devolução de aproximadamente $R \$ 6,472$ milhões (ver Apêndice D: Tabelas I, J, K, L e M). 


\subsubsection{Redução do poder de compra dos recursos transferidos}

Segundos os artigos $n^{\circ} 43,54$ e 64, da $\mathrm{Pl} n^{\circ}$ 507/2011, os recursos financeiros dos acordos de transferências voluntárias deverão ser depositados em contas bancárias específicas, em instituições financeiras controladas pela União, vedado saques ou pagamentos alheios à consecução do objeto conveniado.

Ainda, segundo o que estabelece $\circ \S 1^{\circ}$ do art. 54, os recursos enquanto não utilizados para a consecução do objeto do acordo deverão ser aplicados, conforme a previsão de utilização dos recursos, nas seguintes modalidades:

I - em caderneta de poupança de instituição financeira pública federal, se a previsão de seu uso for igual ou superior a um mês; $e$

II - em fundo de aplicação financeira de curto prazo, ou operação de mercado aberto lastreada em título da dívida pública, quando sua utilização estiver prevista para prazos menores;

$(\ldots)$

Conforme exposto no Tópico 4.2, diversos acordos invariavelmente tem execuções anuais. Dessa forma, a regra do Inciso I, do art. 54 da referida Portaria Interministerial a eles é imposta, ou seja, os recursos sem utilização deverão ser aplicados em caderneta de poupança a uma taxa anual de $6 \%+T R$.

No entanto, conforme a conjuntura econômica, em específico a variação dos índices de preços, em que pese que os recursos estejam depositados em regime de poupança, a depender da variação os recursos financeiros podem ter desvalorizações afetando o poder de aquisição de insumos, bens ou serviços previstos nos planos de trabalhos.

A título de exemplo, conforme apontado na Tabela 7, elaborado a partir da ferramenta disponível no sítio do Banco Central do Brasil (BACEN), intitulada de Calculadora do Cidadão ${ }^{26}$, verificamos para o período $01 / 07 / 2008^{27}$ a 31/05/2016 um rendimento derivado de aplicação de recurso na poupança de $61,37 \%$. Por outro lado, em referência ao Índice de Preços ao Consumidor Amplo - IPCA, para o mesmo período, foi observado no acumulado $65,13 \%$ de inflação. Dessa forma, os recursos aplicados na poupança tiveram uma perda nominal de $3,76 \%$, no período.

\footnotetext{
${ }^{26}$ Acessível em: https://www3.bcb.gov.br/CALCIDADAOPelaPoupanca

27 Utilizou-se essa data para compatibilizar com as datas de análises dos dados de execução de convênios e contratos de repasses do sistema Siconv, instituído em 25 de julho de 2007, pelo Decreto $\mathrm{n}^{\circ}$ 6.170/07.
} 
Tabela 7 - Variação dos índices de inflação e poupança - período 01/07/2008-31/05/2016 - em \%.

\begin{tabular}{cccc}
\hline Período & IPCA & Poupança & Perda Nominal \\
\hline 01/07/2008 a 31/05/2016 & 65,13 & 61,37 & $-3,76$ \\
\hline
\end{tabular}

Fonte: Adaptado de Calculadora do Cidadão - Banco Central do Brasil (BACEN) ${ }^{28}$, em 06/07/2016.

Diante desse quadro, a depender da variação de preços, os recursos de transferências voluntárias podem ter uma perda no poder de aquisição, inviabilizando a consecução dos planos de trabalhos ou impondo a necessidade de termo aditivo quanto a valor, cujo acréscimo financeiro invariavelmente recai sobre o convenente.

\subsubsection{Atrasos na prestação de contas}

A prestação de contas constitui dever de todos que de alguma forma lidam com os recursos públicos.

Conforme citado no Tópico II - Controle sobre a gestão pública, o ato de prestar contas é um dos fundamentos da Administração Pública, por meio da qual os gestores públicos demonstram à boa e regular aplicação dos recursos públicos aos órgãos de controle e, sobretudo, para a sociedade.

Dessa forma, por meio da prestação de contas, os gestores submetem o desempenho da gestão para os administrados, cabendo aqueles a adequada divulgação para estes tomarem nota dos atos e fatos relacionados à execução das politicas públicas.

Em relação a transferências de recursos voluntários da União, o dever de prestar contas dos recursos disponíveis cabe tanto aos órgãos federais repassadores desses recursos quanto às diversas entidades receptores dos recursos.

Diante disso, analisando os dados de prestações de contas de recursos de transferências voluntárias, disponíveis no SICONV, observamos no período de 2008 a 2015 o atraso na prestação de contas de 19.858 acordos, conforme apontado na

28 Acessível em: http://economia.uol.com.br/financas-pessoais/calculadoras/2013/01/01/indices-deinflacao.htm. 
Tabela 8. Ou seja, o equivalente a cerca de $R \$ 17,846$ bilhões de reais estão em atraso quanto à análise e as subsequentes aprovação ou reprovação da execução dos recursos disponibilizados para as diversas entidades públicas ou privadas sem fins lucrativos, que pactuaram a execução descentralizada de políticas públicas de interesses recíprocos com os órgãos da União. 
Tabela 8 - Atrasos na prestação de contas - todos os partícipes - em $R \$$.

\begin{tabular}{ccccccc}
\hline \multirow{2}{*}{ Ano } & \multirow{2}{*}{$\begin{array}{c}\text { Quantidade de } \\
\text { Acordos }\end{array}$} & $\begin{array}{c}\text { Tempo Médio para } \\
\text { Execução }\end{array}$ & & Repasse & Contrapartida & Global \\
\cline { 4 - 7 } & & 2,04 & $1.635 .945 .625,43$ & $306.930 .634,04$ & $1.942 .876 .259,47$ & $1.261 .668 .157,31$ \\
2008 & 1.390 & 2,58 & $4.332 .175 .272,08$ & $689.651 .349,20$ & $5.021 .826 .621,28$ & $3.381 .982 .849,22$ \\
2009 & 5.718 & 2,45 & $2.942 .858 .149,88$ & $372.035 .082,86$ & $3.314 .893 .232,74$ & $2.378 .615 .096,49$ \\
2010 & 4.563 & 2,76 & $2.875 .109 .384,43$ & $179.282 .305,40$ & $3.057 .110 .368,56$ & $2.471 .518 .985,46$ \\
2011 & 2.432 & 2,34 & $2.184 .669 .078,16$ & $182.806 .572,03$ & $2.462 .911 .141,29$ & $1.580 .502 .562,07$ \\
2012 & 2.256 & 1,85 & $1.562 .051 .532,91$ & $101.900 .009,00$ & $1.663 .951 .541,91$ & $898.221 .022,18$ \\
2013 & 2.687 & 1,20 & $337.805 .114,54$ & $16.363 .150,71$ & $354.168 .265,25$ & $233.343 .348,99$ \\
2014 & 748 & 0,324 & $28.436 .323,90$ & $718.697,48$ & $29.155 .021,38$ & $27.632 .209,17$ \\
2015 & 64 & 2,353674276 & $15.899 .050 .481,33$ & $1.849 .687 .800,72$ & $17.846 .892 .451,88$ & $12.233 .484 .230,89$ \\
\hline
\end{tabular}

Fonte: Adaptado de SICONV (2016). 
Desse total de 19.858 acordos que estão em atraso na prestação de contas, observamos que $51,4 \%$ estão nas situações de "prestação de constas em análise" ou "prestação de contas enviada para analise". Ou seja, a análise da prestação de contas está a cargo dos órgãos da União. Diante disso, a quantia por volta de $R \$$ 9,169 bilhões está com a análise da prestação de contas em atraso, em relação ao repasse da União aos diversos participes, conforme demonstrado na Tabela 9.

Tabela 9 - Atrasos na análise da prestação de contas - órgãos da União - em R $\$$.

\begin{tabular}{ccc}
\hline Ano & Quantidade de Acordos & Valor de Repasse \\
\hline 2008 & 969 & $1.088 .671 .174,33$ \\
2009 & 3.107 & $2.699 .519 .562,58$ \\
2010 & 2.374 & $1.739 .961 .972,39$ \\
2011 & 1.287 & $1.680 .351 .391,29$ \\
2012 & 1.137 & $1.184 .648 .572,46$ \\
2013 & 951 & $618.744 .549,65$ \\
2014 & 352 & $149.578 .949,41$ \\
2015 & 30 & $7.991 .402,97$ \\
Total & $\mathbf{1 0 . 2 0 7}$ & $\mathbf{9 . 1 6 9 . 4 6 7 . 5 7 5 , 0 8}$ \\
\hline
\end{tabular}

Fonte: Adaptado de SICONV (2016).

Em relação às situações de "aguardando prestação de contas" e "prestação de contas em complementação", situações que indicam o momento de ação dos diversos participes na obrigação de enviar ou complementar a prestação de contas, verificamos os $48,6 \%$ de registros de atrasos na prestação de contas são motivados pelas entidades que receberam os recursos da União, no que representa $R \$ 6,729$ bilhões que ainda não tiveram a conclusão da prestação de contas, motivado pela falta de documentações a enviar aos órgãos federais concedentes dos recursos, conforme apontado na Tabela 10. 
Tabela 10 - Atrasos na entrega das documentações para a prestação de contas - diversas entidades $-\mathrm{em} R \$$.

\begin{tabular}{ccc}
\hline Ano & Quantidade de Acordos & Valor de Repasse \\
\hline 2008 & 421 & $547.274 .451,10$ \\
2009 & 2.611 & $1.632 .655 .709,50$ \\
2010 & 2.189 & $1.202 .896 .177,49$ \\
2011 & 1.145 & $1.194 .757 .993,14$ \\
2012 & 1.119 & $1.000 .020 .505,70$ \\
2013 & 1.736 & $943.306 .983,26$ \\
2014 & 396 & $188.226 .165,13$ \\
2015 & 34 & $20.444 .920,93$ \\
Total & 9.651 & $6.729 .582 .906,25$ \\
\hline
\end{tabular}

Fonte: Adaptado de SICONV (2016).

Sendo assim, sobre tais acordos em situação de prestação de contas, a sociedade está impossibilitada de analisar se os recursos foram devidamente geridos e se a gestão foi proba quanto à aplicação dos recursos, devido aos atrasos sistemáticos na prestação de contas, motivados tanto por parte dos órgãos da União quanto por parte das diversas entidades públicas e privadas sem fins lucrativos que pactuaram a execução de objetos de políticas públicas de interesses recíprocos.

Portanto, o poder de fiscalização da sociedade sobre os recursos de transferências voluntárias é reduzido devido aos atrasos na prestação de contas.

\subsection{Análise qualitativa: avaliação quanto às percepções levantadas em relação ao processo de transferências de recursos}

\subsubsection{Qualificação dos respondentes}

A pesquisa com o foco no grupo "gestores municipais" contou com as respostas de 62 gestores que lidam com recursos de transferências voluntárias da União, repassados para os seus respectivos municípios, ou seja, 62 municípios, distribuídos nos estados das cinco regiões, conforme apresentado no Quadro 12, a seguir. 
Quadro 12 - Localização dos respondentes municipais.

\begin{tabular}{|c|c|c|}
\hline Região & Estado & Número de Respondentes \\
\hline \multirow{3}{*}{ Sul } & PR & 4 \\
\hline & RS & 6 \\
\hline & SC & 3 \\
\hline \multirow{3}{*}{ Sudeste } & $M G$ & 5 \\
\hline & $\mathrm{RJ}$ & 3 \\
\hline & SP & 11 \\
\hline \multirow{2}{*}{ Norte } & $A C$ & 1 \\
\hline & TO & 1 \\
\hline \multirow{9}{*}{ Nordeste } & $A L$ & 1 \\
\hline & $\mathrm{BA}$ & 3 \\
\hline & CE & 3 \\
\hline & ES & 2 \\
\hline & PB & 1 \\
\hline & $\mathrm{PE}$ & 2 \\
\hline & $\mathrm{PI}$ & 2 \\
\hline & SE & 2 \\
\hline & GO & 5 \\
\hline \multirow{3}{*}{ Centro-Oeste } & $M G$ & 1 \\
\hline & MS & 2 \\
\hline & MT & 4 \\
\hline Total & 20 & 62 \\
\hline
\end{tabular}

Fonte: Elaborado pelo autor.

A quantidade de municípios abrangidos pela pesquisa representam em 1,11\%\%, em referencia aos 5.570 municípios presentes na federação brasileira. Diante disso, a pesquisa limita-se as percepções dos gestores dos 62 municípios analisados, não permitindo a ampliação dos resultados para o conjunto dos municípios.

Conforme dados da Tabela 11, elaborado a partir das respostas ao questionário, a maior parte do grupo é possuidora de nível superior, ou seja, $63 \%$ dos respondentes declaram serem graduados. E do total dos 62 respondentes, $56 \%$ declaram ocupar cargos de chefia. 
Tabela 11 - Qualificação básica dos gestores municipais - em \%.

\begin{tabular}{lcc}
\hline & \multicolumn{3}{c}{ Nível de Escolaridade } \\
\cline { 2 - 4 } & Médio & Superior \\
\hline Quantidade de Respondentes & 37 & 25 \\
Percentual & 59,68 & 40,32 \\
\hline & \multicolumn{3}{c}{ Cargo de Chefia } \\
\hline & \multicolumn{3}{c}{ Não } \\
\hline Quantidade de Respondentes & 21 & 41 \\
Percentual & 33,87 & 66,13 \\
\hline
\end{tabular}

Fonte: Elaborado pelo autor.

Em relação ao grau de instrução dos gestores municipais, 59,67\% dos respondentes declaram ter apenas o nível médio e 40,33\% possuem nível superior.

Quanto à formação daqueles que declaram serem diplomados, $32 \%$ são formados em Administração, e em seguida $20 \%$ são formados em Contabilidade. Chama atenção a presença de outras formações que não possuem formações especificas para a gestão de recursos financeiros públicos, tais como: biologia, secretariado, historia e outros, conforme apresentado no Gráfico 4.

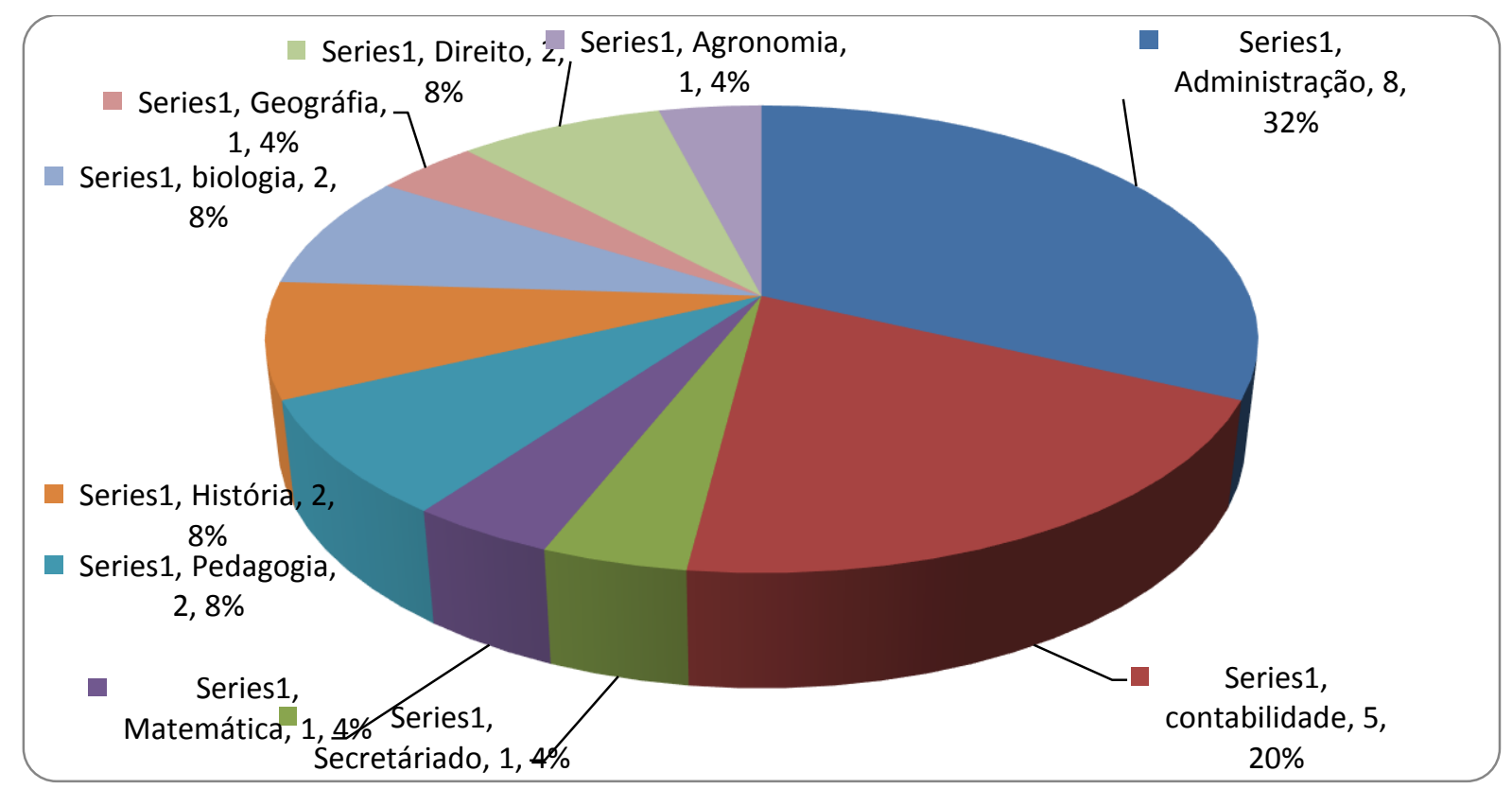

Gráfico 4 - Formação dos gestores municipais que mencionaram ter graduação - unidade.

Fonte: Elaborado pelo autor. 
Em relação à dedicação do tempo laboral, registramos que $56 \%$ dos respondentes realizam suas atividades exclusivamente na gestão dos recursos de transferências voluntarias, $44 \%$ com o compartilhamento do seu tempo para outras atividades.

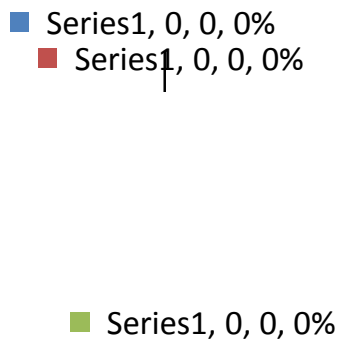

Series1, 0, 0, 0\%

Gráfico 5 - Dedicação à atividade de captação e gestão de recursos de transferências voluntárias dos gestores municipais.

Fonte: Elaborado pelo autor.

No que tange a experiência na atividade, a grande maioria $(75,8 \%)$, declaram ter entre 1 a 6 anos de experiência, conforme demonstrado na Tabela 12. Chama a atenção o maior número de servidores com experiência declarada entre 1 a 3 anos, significando uma alta rotatividade na atividade.

Tabela 12 - Anos de experiência no setor de lotação - gestores municipais - em \%.

\begin{tabular}{ccc}
\hline Classes & Frequência Absoluta & Frequência Relativa \\
\hline $1-3$ & 25 & 40,32 \\
$4-6$ & 22 & 35,48 \\
$7-9$ & 9 & 14,52 \\
10 ou mais & 6 & 9,68 \\
Total & 62 & 100 \\
\hline
\end{tabular}

Fonte: Elaborado pelo autor. 
Em relação ao grupo "gestores distritais", observamos que todos os 13 respondentes manifestaram possuir cursos de nível superior, e 54\% declaram ser ocupantes de cargos de chefia ou assessoramento.

Em relação à formação dos agentes públicos da área de gestão de recursos de transferências voluntárias, quatro declaram formação em administração e em direito e contabilidade, registramos duas ocorrências. Para os demais registramos uma participação cada.

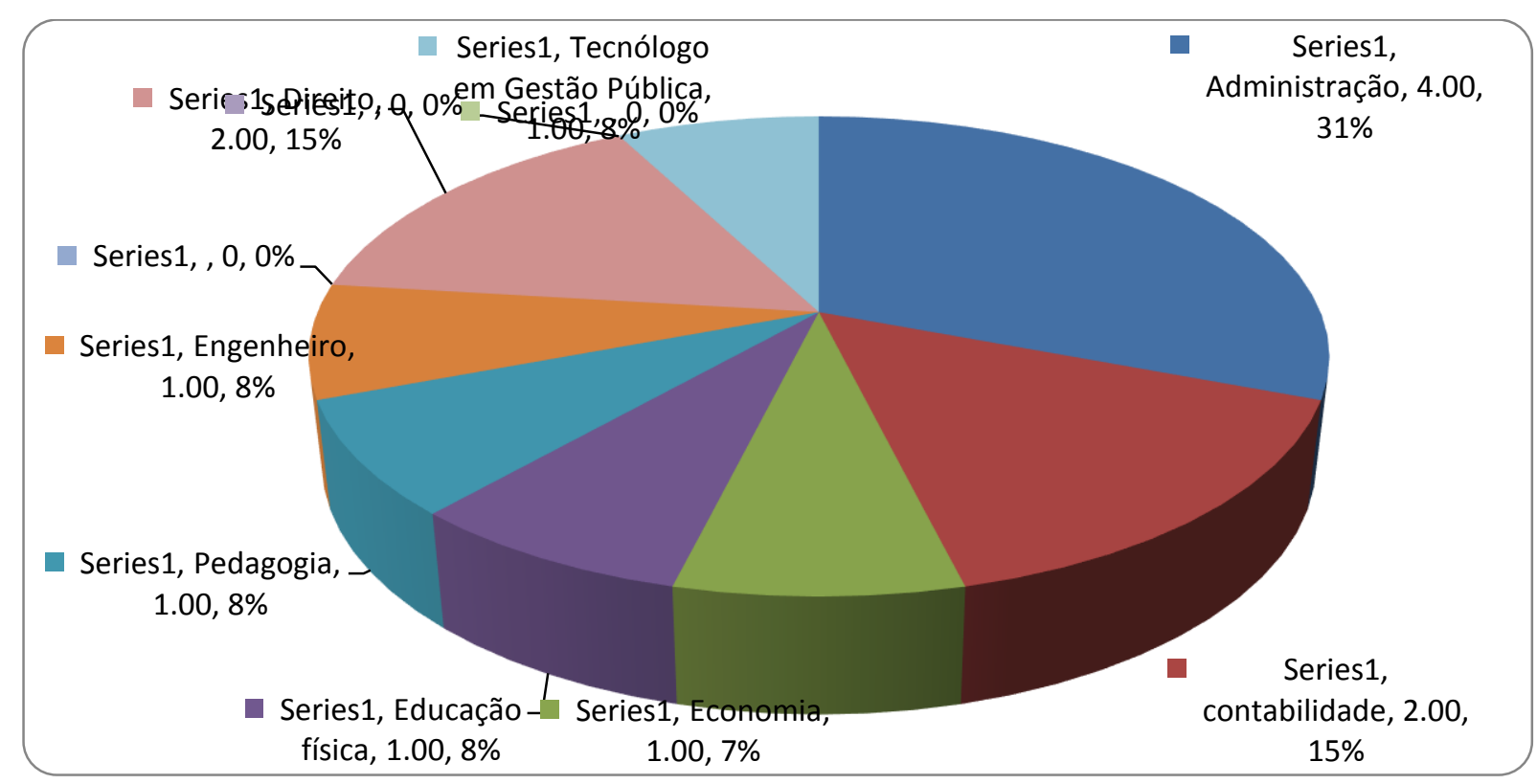

Gráfico 6 - Formação dos gestores distritais que mencionaram ter graduação -unidade.

Fonte: Elaborado pelo autor.

Em relação à dedicação do tempo na jornada de trabalho, $62 \%$ dos respondentes manifestaram a dedicação exclusiva à atividade, contra $38 \%$ que compartilham seus tempos com atividades alheias à gestão dos recursos de transferências voluntárias da União. 


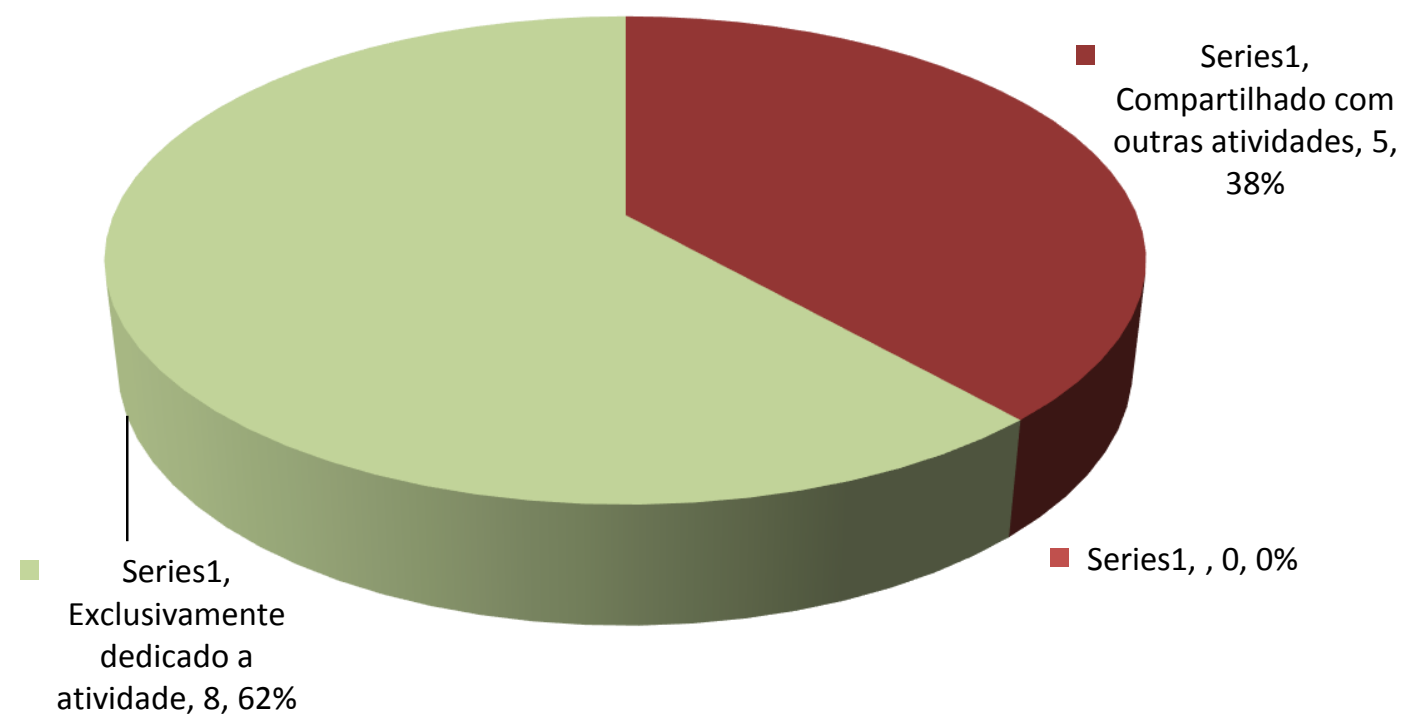

Gráfico 7 - Dedicação à atividade de captação e gestão de recursos de transferências voluntárias dos gestores distritais - em \%.

Fonte: Elaborado pelo autor.

Quanto à experiência na atividade, conforme os dados da Tabela 13, a grande maioria $(61,54 \%)$ declarou ter entre 1 a 6 anos de experiência. Chama à atenção o maior número de servidores com experiência declarada entre 1 a 3 anos $(38 \%)$, significando, igualmente às características municipais analisada neste trabalho, uma alta rotatividade na atividade de gestão de recursos de transferências voluntárias da União.

Tabela 13 - Anos de experiência no setor de lotação - gestores distritais - em \%.

\begin{tabular}{ccc}
\hline Classes & Frequência Absoluta & Frequência Relativa \\
\hline $1-3$ & 5 & 38,46 \\
$4-6$ & 3 & 23,08 \\
$7-9$ & 3 & 23,08 \\
10 ou mais & 2 & 15,38 \\
Total & 13 & 100 \\
\hline
\end{tabular}

Fonte: Elaborado pelo autor.

Conclui-se que tanto para os gestores municipais quanto para os distritais há uma alta rotatividade de servidores na atividade de gestão de recursos de transferências voluntárias da União; a divisão da jornada de trabalhos com outras 
atividades alheias a gestão desses recursos; a ocupação de profissionais sem a qualificação adequada para a atividade (pedagogo, historiador, secretariado etc.).

\subsubsection{Qualificação dos respondentes}

Os resultados obtidos com a aplicação do questionário foram tabulados sob a forma de painel de dados e agrupados em duas categorias: Gestores Distritais e Gestores Municipais.

Os resultados foram tabulados com a ajuda de recursos informatizados do pacote Microsoft Office e todas as análises foram realizadas utilizando o software IBM SPSS Statistics, versão 22. 
Tabela 14 - Resultados do questionário aplicado aos gestores distritais e municipais (continua).

\begin{tabular}{|c|c|c|c|c|c|c|c|c|c|}
\hline \multirow{2}{*}{\multicolumn{2}{|c|}{ Questões }} & \multicolumn{4}{|c|}{ Respostas Gestores Distrital } & \multicolumn{4}{|c|}{ Respostas Gestores Municipais } \\
\hline & & Somatório & Média & DesvPad & ErroPad & Somatório & Média & DesvPad & ErroPad \\
\hline a1 & $\begin{array}{l}\text { Na fase de elaboração do } \\
\text { PPA da União, a União } \\
\text { disponibiliza canais de } \\
\text { comunicação para } \\
\text { apresentação de propostas } \\
\text { de políticas públicas? }\end{array}$ & 41 & 3,15 & 1,68 & 0,46 & 200 & 3,23 & 1,95 & 0,25 \\
\hline a3 & $\begin{array}{l}\text { Considerando as proposições } \\
\text { perante os setoriais de } \\
\text { planejamento da União, há } \\
\text { uma boa receptividade quanto } \\
\text { ao atendimento das } \\
\text { demandas do seu órgão? }\end{array}$ & 36 & 2,77 & 1,96 & 0,54 & 159 & 2,56 & 1,98 & 0,25 \\
\hline
\end{tabular}


Tabela 14 - Resultados do questionário aplicado aos gestores distritais e municipais (continuação).

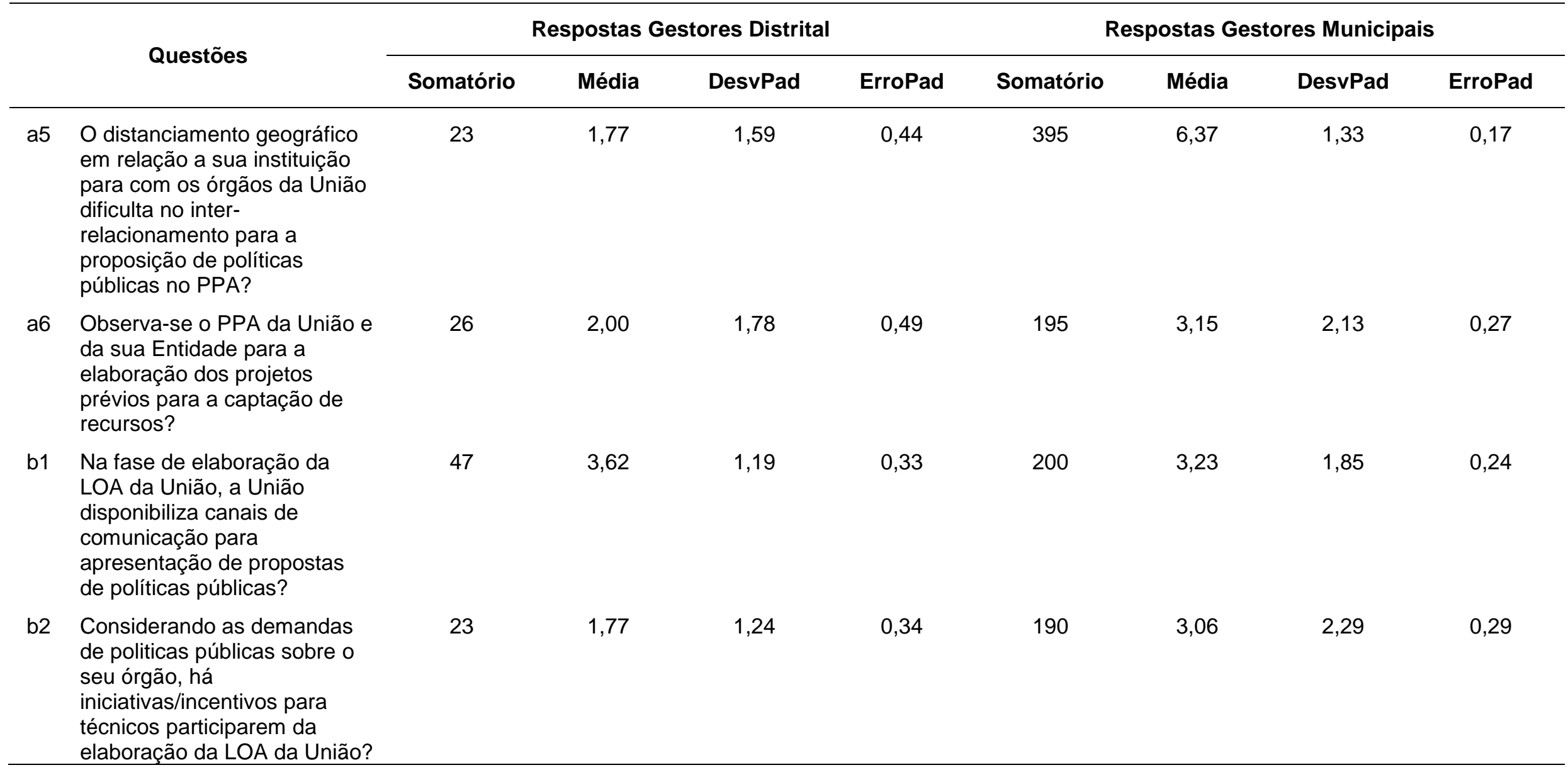


Tabela 14 - Resultados do questionário aplicado aos gestores distritais e municipais (continuação).

\begin{tabular}{|c|c|c|c|c|c|c|c|c|c|}
\hline \multirow{2}{*}{\multicolumn{2}{|c|}{ Questões }} & \multicolumn{4}{|c|}{ Respostas Gestores Distrital } & \multicolumn{4}{|c|}{ Respostas Gestores Municipais } \\
\hline & & Somatório & Média & DesvPad & ErroPad & Somatório & Média & DesvPad & ErroPad \\
\hline b3 & $\begin{array}{l}\text { Considerando as interações } \\
\text { perante os setoriais da União, } \\
\text { há uma boa receptividade das } \\
\text { propostas de objetos de } \\
\text { políticas públicas por parte } \\
\text { dos técnicos da União? }\end{array}$ & 35 & 2,69 & 2,18 & 0,60 & 164 & 2,65 & 1,78 & 0,23 \\
\hline b4 & $\begin{array}{l}\text { Considerando os tramites da } \\
\text { elaboração da LOA, o seu } \\
\text { órgão possui colaborados } \\
\text { com conhecimentos } \\
\text { adequados para participarem } \\
\text { da elaboração de propostas } \\
\text { na LOA da União? }\end{array}$ & 36 & 2,77 & 2,13 & 0,59 & 226 & 3,65 & 1,92 & 0,24 \\
\hline b5 & $\begin{array}{l}\text { O distanciamento geográfico } \\
\text { da sua instituição para com } \\
\text { os órgãos da União dificulta } \\
\text { no inter-relacionamento e } \\
\text { apresentação das demandas } \\
\text { do seu órgão? }\end{array}$ & 24 & 1,85 & 1,28 & 0,36 & 425 & 6,85 & 1,00 & 0,13 \\
\hline b6 & $\begin{array}{l}\text { Observa-se a LOA da União e } \\
\text { da sua Entidade para a } \\
\text { elaboração dos projetos } \\
\text { prévios para a captação de } \\
\text { recursos? }\end{array}$ & 25 & 1,92 & 1,38 & 0,38 & 194 & 3,13 & 1,78 & 0,23 \\
\hline
\end{tabular}


Tabela 14 - Resultados do questionário aplicado aos gestores distritais e municipais (continuação).

\begin{tabular}{|c|c|c|c|c|c|c|c|c|c|}
\hline \multirow{2}{*}{\multicolumn{2}{|c|}{ Questões }} & \multicolumn{4}{|c|}{ Respostas Gestores Distrital } & \multicolumn{4}{|c|}{ Respostas Gestores Municipais } \\
\hline & & Somatório & Média & DesvPad & ErroPad & Somatório & Média & DesvPad & ErroPad \\
\hline$c 1$ & $\begin{array}{l}\text { Anterior ao repasse de } \\
\text { recursos houve transferências } \\
\text { de conhecimentos em relação } \\
\text { à gestão, a exemplo de } \\
\text { cursos de capacitações, } \\
\text { workshops, reuniões etc. com } \\
\text { os órgãos da União? }\end{array}$ & 34 & 2,62 & 2,06 & 0,57 & 185 & 2,98 & 2,27 & 0,29 \\
\hline $\mathrm{c} 2$ & $\begin{array}{l}\text { Os órgãos da União instituem } \\
\text { práticas rotineiras para a } \\
\text { identificação de pontos } \\
\text { críticos no processo de } \\
\text { repasses de recursos e as } \\
\text { disseminam aos órgãos } \\
\text { estaduais ou municipais } \\
\text { recebedores dos recursos? }\end{array}$ & 26 & 2,00 & 2,04 & 0,57 & 169 & 2,73 & 1,92 & 0,24 \\
\hline c3 & $\begin{array}{l}\text { Gestores públicos locais com } \\
\text { poder decisório tiveram } \\
\text { reuniões de integração com } \\
\text { Gestores Federais para } \\
\text { alinhamento das estratégias } \\
\text { nos programas a serem } \\
\text { executados de forma } \\
\text { descentralizada? }\end{array}$ & 31 & 2,38 & 2,29 & 0,64 & 96 & 1,55 & 1,21 & 0,15 \\
\hline c4 & $\begin{array}{l}\text { Técnicos do seu órgão } \\
\text { tiveram ou tem reuniões ou } \\
\text { capacitações rotineiras para } \\
\text { a elaboração dos projetos a } \\
\text { serem apresentados? }\end{array}$ & 31 & 2,38 & 2,02 & 0,56 & 97 & 1,56 & 1,12 & 0,14 \\
\hline
\end{tabular}


Tabela 14 - Resultados do questionário aplicado aos gestores distritais e municipais (continuação).

\begin{tabular}{|c|c|c|c|c|c|c|c|c|c|}
\hline \multirow{2}{*}{\multicolumn{2}{|c|}{ Questões }} & \multicolumn{4}{|c|}{ Respostas Gestores Distrital } & \multicolumn{4}{|c|}{ Respostas Gestores Municipais } \\
\hline & & Somatório & Média & DesvPad & ErroPad & Somatório & Média & DesvPad & ErroPad \\
\hline c5 & $\begin{array}{l}\text { Técnicos do seu órgão } \\
\text { tiveram apoio técnico dos } \\
\text { técnicos dos órgãos da União } \\
\text { para a elaboração dos } \\
\text { projetos? }\end{array}$ & 23 & 1,77 & 0,93 & 0,26 & 80 & 1,29 & 1,07 & 0,14 \\
\hline C6 & $\begin{array}{l}\text { Seu órgão possui capacidade } \\
\text { para a elaboração de } \\
\text { projetos, sem o auxilio de } \\
\text { outros órgãos ou entidades? }\end{array}$ & 48 & 3,69 & 2,06 & 0,57 & 159 & 2,56 & 1,42 & 0,18 \\
\hline c7 & $\begin{array}{l}\text { A capacidade técnico- } \\
\text { operacionais declaradas por } \\
\text { seu órgão, nos planos de } \\
\text { trabalhos, reflete a real } \\
\text { capacidade para executar o } \\
\text { objeto da política pública? }\end{array}$ & 39 & 3,00 & 1,78 & 0,49 & 153 & 2,47 & 1,45 & 0,18 \\
\hline c8 & $\begin{array}{l}\text { O distanciamento geográfico } \\
\text { da sua instituição para com } \\
\text { os órgãos da União dificultam } \\
\text { no inter-relacionamento para } \\
\text { a formatação do projeto? }\end{array}$ & 27 & 2,08 & 1,50 & 0,42 & 417 & 6,73 & 1,11 & 0,14 \\
\hline d1 & $\begin{array}{l}\text { Há visitas sistemáticas de } \\
\text { técnicos da União para } \\
\text { verificar o andamento dos } \\
\text { grandes projetos executados } \\
\text { por sua entidade? }\end{array}$ & 32 & 2,46 & 1,90 & 0,53 & 99 & 1,60 & 1,37 & 0,17 \\
\hline
\end{tabular}


Tabela 14 - Resultados do questionário aplicado aos gestores distritais e municipais (continuação).

\begin{tabular}{|c|c|c|c|c|c|c|c|c|c|}
\hline \multicolumn{2}{|r|}{ Questões } & \multicolumn{4}{|c|}{ Respostas Gestores Distrital } & \multicolumn{4}{|c|}{ Respostas Gestores Municipais } \\
\hline d2 & $\begin{array}{l}\text { Há frequentes comunicados } \\
\text { dos técnicos da União quanto } \\
\text { à observação de atrasos na } \\
\text { execução dos objetos dos } \\
\text { acordos? }\end{array}$ & 33 & 2,54 & 1,71 & 0,48 & 278 & 4,48 & 1,58 & 0,20 \\
\hline d4 & $\begin{array}{l}\text { O distanciamento geográfico } \\
\text { da sua instituição para com } \\
\text { os órgãos da União dificulta } \\
\text { no inter-relacionamento para } \\
\text { o acompanhamento da } \\
\text { execução? }\end{array}$ & 25 & 1,92 & 1,04 & 0,29 & 389 & 6,27 & 1,19 & 0,15 \\
\hline d6 & $\begin{array}{l}\text { A união apoia a realização de } \\
\text { eventos para a disseminação } \\
\text { das melhores praticas para a } \\
\text { execução dos recursos de } \\
\text { transferências voluntárias? }\end{array}$ & 29 & 2,23 & 1,88 & 0,52 & 117 & 1,89 & 1,32 & 0,17 \\
\hline
\end{tabular}


Tabela 14 - Resultados do questionário aplicado aos gestores distritais e municipais (continuação).

\begin{tabular}{|c|c|c|c|c|c|c|c|c|c|}
\hline \multirow{2}{*}{\multicolumn{2}{|c|}{ Questões }} & \multicolumn{4}{|c|}{ Respostas Gestores Distrital } & \multicolumn{4}{|c|}{ Respostas Gestores Municipais } \\
\hline & & Somatório & Média & DesvPad & ErroPad & Somatório & Média & DesvPad & ErroPad \\
\hline d7 & $\begin{array}{l}\text { De forma geral, como você } \\
\text { classifica a gestão da União } \\
\text { sobre os recursos } \\
\text { descentralizados para o seu } \\
\text { órgão? }\end{array}$ & 43 & 3,31 & 1,25 & 0,35 & 160 & 2,58 & 1,46 & 0,19 \\
\hline e1 & $\begin{array}{l}\text { Existem recomendações do } \\
\text { controle interno do } \\
\text { estado/município para a } \\
\text { melhoria de gestão dos } \\
\text { recursos recebidos por seu } \\
\text { órgão? }\end{array}$ & 33 & 2,54 & 1,94 & 0,54 & 113 & 1,82 & 1,51 & 0,19 \\
\hline e2 & $\begin{array}{l}\text { Existem recomendações do } \\
\text { controle externo da União } \\
\text { para a melhoria da gestão } \\
\text { dos recursos repassados pela } \\
\text { a União ao seu órgão? }\end{array}$ & 33 & 2,54 & 1,98 & 0,55 & 185 & 2,98 & 1,65 & 0,21 \\
\hline e3 & $\begin{array}{l}\text { Há considerações do seu } \\
\text { órgão sobre as } \\
\text { recomendações do controle } \\
\text { interno/externo? }\end{array}$ & 59 & 4,54 & 1,13 & 0,31 & 254 & 4,10 & 1,62 & 0,21 \\
\hline e4 & $\begin{array}{l}\text { As unidades de controle } \\
\text { interno acompanham a } \\
\text { execução e a prestação de } \\
\text { contas dos recursos } \\
\text { recebidos de forma } \\
\text { sistemática? }\end{array}$ & 23 & 1,77 & 1,48 & 0,41 & 103 & 1,66 & 1,29 & 0,16 \\
\hline
\end{tabular}


Tabela 14 - Resultados do questionário aplicado aos gestores distritais e municipais (continuação).

\begin{tabular}{|c|c|c|c|c|c|c|c|c|c|}
\hline \multirow{2}{*}{\multicolumn{2}{|c|}{ Questões }} & \multicolumn{4}{|c|}{ Respostas Gestores Distrital } & \multicolumn{4}{|c|}{ Respostas Gestores Municipais } \\
\hline & & Somatório & Média & DesvPad & ErroPad & Somatório & Média & DesvPad & ErroPad \\
\hline e5 & $\begin{array}{l}\text { É verificada a participação do } \\
\text { controle social sobre a } \\
\text { atividade de captação e } \\
\text { execução de recursos } \\
\text { públicos? }\end{array}$ & 22 & 1,69 & 1,49 & 0,41 & 49 & 0,79 & 0,79 & 0,10 \\
\hline e6 & $\begin{array}{l}\text { As informações sobre a } \\
\text { execução físico-financeira } \\
\text { estão disponíveis em tempo } \\
\text { real para a população focal da } \\
\text { política pública? }\end{array}$ & 15 & 1,15 & 1,14 & 0,32 & 44 & 0,71 & 0,71 & 0,09 \\
\hline e7 & $\begin{array}{l}\text { Há mecanismos/sistema para } \\
\text { o acompanhamento da } \\
\text { execução físico/financeira } \\
\text { pelas partes interessadas, } \\
\text { além do sistema Siconv? }\end{array}$ & 20 & 1,54 & 1,13 & 0,31 & 68 & 1,10 & 1,02 & 0,13 \\
\hline $\mathrm{f1}$ & $\begin{array}{l}\text { Você considera que a alta } \\
\text { administração do seu órgão } \\
\text { está envolvida na busca por } \\
\text { melhores práticas para a } \\
\text { captação de recursos? }\end{array}$ & 35 & 2,69 & 1,93 & 0,54 & 137 & 2,21 & 1,36 & 0,17 \\
\hline f2 & $\begin{array}{l}\text { Você considera que a alta } \\
\text { administração do seu órgão } \\
\text { está envolvida na busca por } \\
\text { melhores práticas para a } \\
\text { execução dos recursos } \\
\text { recebidos? }\end{array}$ & 33 & 2,54 & 1,81 & 0,50 & 124 & 2,00 & 1,12 & 0,14 \\
\hline
\end{tabular}


Tabela 14 - Resultados do questionário aplicado aos gestores distritais e municipais (continuação).

\begin{tabular}{|c|c|c|c|c|c|c|c|c|c|}
\hline \multicolumn{2}{|r|}{ Questões } & \multicolumn{4}{|c|}{ Respostas Gestores Distrital } & \multicolumn{4}{|c|}{ Respostas Gestores Municipais } \\
\hline f3 & $\begin{array}{l}\text { Você considera que a alta } \\
\text { administração da União está } \\
\text { envolvida na busca por } \\
\text { melhores práticas para o } \\
\text { repasse dos recursos? }\end{array}$ & 34 & 2,62 & 1,19 & 0,33 & 161 & 2,60 & 1,31 & 0,17 \\
\hline f5 & $\begin{array}{l}\text { As iniciativas e propostas } \\
\text { para melhoria no processo de } \\
\text { captação e execução de } \\
\text { recursos são consideradas } \\
\text { pela alta administração do } \\
\text { seu órgão? }\end{array}$ & 29 & 2,23 & 2,01 & 0,56 & 126 & 2,03 & 1,38 & 0,17 \\
\hline g1 & $\begin{array}{l}\text { Ocorreu alguma alteração no } \\
\text { modo de gerir os recursos } \\
\text { com a instituição do Sistema } \\
\text { SICONV? }\end{array}$ & 82 & 6,31 & 2,18 & 0,60 & 389 & 6,27 & 1,60 & 0,20 \\
\hline g2 & $\begin{array}{l}\text { O sistema SICONV permitiu } \\
\text { uma melhor integração das } \\
\text { informações de execução dos } \\
\text { recursos com os órgãos } \\
\text { federais? }\end{array}$ & 64 & 4,92 & 1,55 & 0,43 & 406 & 6,55 & 1,61 & 0,20 \\
\hline
\end{tabular}


Tabela 14 - Resultados do questionário aplicado aos gestores distritais e municipais (continuação).

\begin{tabular}{|c|c|c|c|c|c|c|c|c|c|}
\hline \multirow{2}{*}{\multicolumn{2}{|c|}{ Questões }} & \multicolumn{4}{|c|}{ Respostas Gestores Distrital } & \multicolumn{4}{|c|}{ Respostas Gestores Municipais } \\
\hline & & Somatório & Média & DesvPad & ErroPad & Somatório & Média & DesvPad & ErroPad \\
\hline g3 & $\begin{array}{l}\text { Com a instituição do Sistema } \\
\text { SICONV promoveu uma } \\
\text { antecipação na identificação } \\
\text { de programas passiveis de } \\
\text { execução por seu órgão? }\end{array}$ & 33 & 2,54 & 1,94 & 0,54 & 140 & 2,26 & 1,40 & 0,18 \\
\hline g4 & $\begin{array}{l}\text { Na instituição do Sistema } \\
\text { SICONV, o seu órgão obteve } \\
\text { nos últimos três nãos o apoio } \\
\text { dos órgãos da União quanto } \\
\text { ao treinamento dos } \\
\text { colaboradores para a } \\
\text { utilização? }\end{array}$ & 20 & 1,54 & 1,33 & 0,37 & 64 & 1,03 & 0,79 & 0,10 \\
\hline g5 & $\begin{array}{l}\text { Em referência ao sistema } \\
\text { SICONV, você considera que } \\
\text { é um sistema que permite o } \\
\text { planejamento? }\end{array}$ & 40 & 3,08 & 2,29 & 0,64 & 176 & 2,84 & 1,29 & 0,16 \\
\hline g6 & $\begin{array}{l}\text { Em referência ao sistema } \\
\text { SICONV, você o considera } \\
\text { como um sistema de gestão? }\end{array}$ & 55 & 4,23 & 2,17 & 0,60 & 230 & 3,71 & 1,55 & 0,20 \\
\hline g7 & $\begin{array}{l}\text { Em referência ao sistema } \\
\text { SICONV, você o considera } \\
\text { como um sistema de } \\
\text { controle? }\end{array}$ & 76 & 5,85 & 1,86 & 0,52 & 332 & 5,35 & 1,59 & 0,20 \\
\hline g8 & $\begin{array}{l}\text { Com relação a sua atividade } \\
\text { diária na utilização do } \\
\text { Sistema SICONV, como você } \\
\text { classificaria o nível de } \\
\text { dificuldade na sua } \\
\text { operacionalização? }\end{array}$ & 96 & 7,38 & 1,56 & 0,43 & 427 & 6,89 & 1,56 & 0,20 \\
\hline
\end{tabular}


Tabela 14 - Resultados do questionário aplicado aos gestores distritais e municipais (conclusão).

\begin{tabular}{|c|c|c|c|c|c|c|c|c|c|}
\hline \multirow{2}{*}{\multicolumn{2}{|c|}{ Questões }} & \multicolumn{4}{|c|}{ Respostas Gestores Distrital } & \multicolumn{4}{|c|}{ Respostas Gestores Municipais } \\
\hline & & Somatório & Média & DesvPad & ErroPad & Somatório & Média & DesvPad & ErroPad \\
\hline h1 & $\begin{array}{l}\text { De forma geral, como você } \\
\text { classifica a atual sistemática } \\
\text { de transferências voluntárias } \\
\text { da União? }\end{array}$ & 57 & 4,38 & 2,26 & 0,63 & 175 & 2,82 & 1,57 & 0,20 \\
\hline h2 & $\begin{array}{l}\text { De forma geral, como você } \\
\text { classifica a o desempenho do } \\
\text { seu órgão na gestão dos } \\
\text { recursos de transferências } \\
\text { voluntárias? }\end{array}$ & 45 & 3,46 & 1,13 & 0,31 & 150 & 2,42 & 1,41 & 0,18 \\
\hline h3 & $\begin{array}{l}\text { De forma geral, você } \\
\text { classifica o processo de } \\
\text { repasses de recursos voltado } \\
\text { para o planejamento? }\end{array}$ & 42 & 3,23 & 1,96 & 0,54 & 192 & 3,10 & 1,06 & 0,14 \\
\hline h4 & $\begin{array}{l}\text { De forma geral, você } \\
\text { classifica o processo de } \\
\text { repasses de recursos voltado } \\
\text { para a Gestão? }\end{array}$ & 68 & 5,23 & 2,59 & 0,72 & 242 & 3,90 & 1,62 & 0,21 \\
\hline h5 & $\begin{array}{l}\text { De forma geral, você } \\
\text { classifica o processo de } \\
\text { repasses de recursos voltado } \\
\text { para o Controle? }\end{array}$ & 75 & 5,77 & 1,96 & 0,54 & 421 & 6,79 & 1,49 & 0,19 \\
\hline
\end{tabular}

Onde: (0) - Não se aplica/nenhuma/péssimo; (1 a 3) - Aplica-se pouco/baixo/ruim; (4 a 7) - Sim, em parte/médio/bom; (8 a 10) - Sim, totalmente/fácil/ótimo.

Fonte: Elaborado pelo autor. 
A análise dos dados do questionário aplicado aos 13 gestores distritais e 62 gestores municipais, considerando a categorização, demonstrou que grande parte das respostas situou-se em: (1 a 3) - Aplica-se pouco/baixo/ruim, em destaque o bloco de questões sobre "Planejamento Orçamentário" e "Gestão", indicando uma baixa avaliação quanto aos inter-relacionamentos com os órgãos da União para a elaboração do PPA, LOA e elaboração de projetos para a execução das políticas públicas de objetivos mútuos.

Neste sentido, tem-se:

- a1 e b1: a1 Na fase de elaboração do PPA da União, a União disponibiliza canais de comunicação para apresentação de propostas de políticas públicas? (DF: Médias 3,15 e Desvio Padrão de 1,68; Municípios: Média 3,23 e Desvio Padrão de 1,95) e b1 - Na fase de elaboração da LOA da União, a União disponibiliza canais de comunicação para apresentação de propostas de políticas públicas? (DF: Médias 3,62 e Desvios Padrão 1,19; Municípios: Média 3,23 e Desvio de 1,85).

- a2 e b2: a2 - Considerando as demandas de políticas públicas sobre seu órgão, há iniciativas/incentivos para que técnicos participem da elaboração do PPA da União? (DF: Médias 1,92 e Desvio Padrão 1,19; Municípios: Média 2,79 e Desvio de 2,08) e b2 - Considerando as demandas de politicas públicas sobre o seu órgão, há iniciativas/incentivos para técnicos participarem da elaboração da LOA da União? (DF: Média 1,77 e Desvio Padrão 1,24; Municípios: Média 3,06 e Desvio de 2,29).

- a3 e b3: a3 - Considerando as proposições perante os setoriais de planejamento da União, há uma boa receptividade quanto ao atendimento das demandas do seu órgão? (Médias 2,77 e 2,56 e Desvio Padrão 1,96 e 1,98, respectivamente) e b3 - Considerando as interações perante os setoriais da União, há uma boa receptividade das propostas de objetos de políticas públicas por parte dos técnicos da União? (DF: Média 2,69 e Desvio Padrão 2,18; Municípios: Média 2,65 e Desvio Padrão de 1,78).

- a4 e b4: a4 - Considerando os tramites para a elaboração do PPA, o seu órgão possui colaborados com conhecimentos adequados para participarem na elaboração de propostas no PPA da União? (DF: Média 3,23 e Desvio Padrão 2,18 e Município: Média: 2,98 e Desvio Padrão 1,74) e b4 Considerando os tramites da elaboração da LOA, o seu órgão possui 
colaborados com conhecimentos adequados para participarem da elaboração de propostas na LOA da União? (DF: Média 2,77 e Desvio Padrão 2,13 e Município: Média: 226 e Desvio Padrão 3,65).

- A6 e b6: a6 - Observa-se o PPA da União e da sua Entidade para a elaboração dos projetos prévios para a captação de recursos? (DF: Média 2,00 e Desvio Padrão 1,78 e Município: Média: 3,15 e Desvio Padrão 2,13) e b6 - Observa-se a LOA da União e da sua Entidade para a elaboração dos projetos prévios para a captação de recursos? (DF: Média 1,92 e Desvio Padrão 1,38 e Município: Média: 3,13 e Desvio Padrão 1,78).

- c1 e c3: Anterior ao repasse de recursos houve transferências de conhecimentos em relação à gestão, a exemplo de cursos de capacitações, workshops, reuniões etc. com os órgãos da União? (DF: Média 2,62 e Desvio Padrão 2,06 e Município: Média: 2,98 e Desvio Padrão 2,27) e Gestores públicos locais com poder decisório tiveram reuniões de integração com Gestores Federais para alinhamento das estratégias nos programas a serem executados de forma descentralizada? (DF: Média 2,38 e Desvio Padrão 2,29 e Município: Média: 1,55 e Desvio Padrão 1,21)

- c2 e d3: c2 - Os órgãos da União instituem práticas rotineiras para a identificação de pontos críticos no processo de repasses de recursos e as disseminam aos órgãos estaduais ou municipais recebedores dos recursos? (DF: Média 2,04 e Desvio Padrão 0,57 e Município: Média: 2,73 e Desvio Padrão 1,92) e d3 - Há frequentes recomendações quanto à adoção de melhores praticas para a execução dos acordos? (DF: Média 2,46 e Desvio Padrão 1,51 e Município: Média: 3,98 e Desvio Padrão 1,57).

- c4 e c5: c4 - Técnicos do seu órgão tiveram ou tem reuniões ou capacitações rotineiras para a elaboração dos projetos a serem apresentados? (DF: Média 2,38 e Desvio Padrão 2,02 e Município: Média: 1,56 e Desvio Padrão 1,12) e Técnicos do seu órgão tiveram apoio técnico dos técnicos dos órgãos da União para a elaboração dos projetos? (DF: Média 1,77 e Desvio Padrão 0,93 e Município: Média: 1,29 e Desvio Padrão 1,07).

- c6 e d5: c6 - Seu órgão possui capacidade para a elaboração de projetos, sem o auxilio de outros órgãos ou entidades? (DF: Média 3,69 e Desvio Padrão 2,06 e Município: Média: 2,56 e Desvio Padrão 1,42) e d6 - O seu 
órgão possui capacidade técnico-operacional para executar as políticas públicas pactuadas com a União? (DF: Média 2,38 e Desvio Padrão 1,12 e Município: Média: 3,61 e Desvio Padrão 1,58).

Em referência as questões a5 e b5, destaca-se o comportamento de oposição entre as respostas dos gestores distritais e municipais conquanto a dificuldade de inter-relacionamento para formatação de proposições de políticas públicas no PPA e LOA, devido ao distanciamento geográfico, em que obtivemos (DF, média: 1,77 e Desvio padrão: 1,59; Municípios, média: 6,37 e Desvio padrão: 1,33).

Assim como nas questões: c8 e d4, relacionadas à interferência do distanciamento geográfico para a formatação de projetos para a execução de políticas públicas com objetivos mútuos e o acompanhamento da execução obtivemos para o DF uma média: 2,08 e Desvio padrão: 1,50 nas respostas. Para os Municípios, média: 6,73 e Desvio padrão: 1,11, respectivamente.

Em relação às respostas das questões d1 - Há visitas sistemáticas de técnicos da União para verificar o andamento dos grandes projetos executados por sua entidade? e d4 - O distanciamento geográfico da sua instituição para com os órgãos da União dificulta no inter-relacionamento para o acompanhamento da execução? Verificamos um baixo score para as respostas para a questão d1, para ambos os grupos de respondentes. No entanto, em relação às respostas da questão d4, verificamos novamente que o distanciamento geográfico dos órgãos da União para com as entidades públicas municipais ocasiona na dificuldade de acompanhamento da execução daqueles para com estes (média 6,27, categoria 4 a 7 - sim, em parte, com desvio padrão de 1,19).

Já em relação aos gestores distritais esse nível de interferência do distanciamento geográfico não tem impacto significante, devido à administração pública distrital ocupar a mesma base geográfica dos repassadores dos recursos, os órgãos da união (média 1,92 e desvio padrão de 1,04).

Esses fatos observados sobre o impacto do distanciamento geográfico entre os órgãos da União para com os municipais (conjunto das respostas sobre as questões a5 e b5, c8 e d4 e d1 e d4) permitem a conclusão que apesar de todo o aparato tecnológico para promover a comunicação, os gestores municipais encontram dificuldades para o inter-relacionamento com os gestores ministeriais para a proposição de políticas públicas nos instrumentos de planejamento 
governamental da União, na formatação de projetos e nas ações de acompanhamento da execução. Diferente dos gestores distritais que compartilham a mesma base geográfica com a cúpula ministerial.

Nas respostas as questões d6 e g4, identificou-se a baixa percepção, tantos dos gestores distritais quanto municipais, em ralação à participação dos órgãos da União na disseminação de melhores práticas para a execução dos recursos de transferências voluntárias e apoio para o treinamento no sistema federal para a gestão dos acordos, o Siconv (resposta d6: DF - média 2,23 e desvio padrão de 1,88; municípios - média 1,89 e desvio de 1,32. Resposta g4: DF - média 1,54 e desvio padrão de 1,33; municípios - média 1,03 com desvio de 0,79).

Em referência às respostas dos gestores municipais identificamos os maiores desvios padrões nas questões: b2 - Considerando as demandas do órgão, há iniciativas/incentivos para técnicos do seu órgão para participarem da elaboração da LOA da União? (Média 3,06 e Desvio Padrão 2,29); c1 - Anterior ao repasse de recursos houve transferências de conhecimentos em relação à gestão, a exemplo de cursos de capacitações, workshops, reuniões etc. com os órgãos da União? (Média 2,98 e Desvio Padrão 2,27); a6 - Observa-se o PPA da União e da sua Entidade para a elaboração dos projetos prévios para a captação de recursos? (Média 3,15 e Desvio Padrão 2,13); e a2 - Considerando as demandas sobre seu órgão de políticas públicas, há iniciativas/incentivos para que técnicos do seu órgão participarem PPA da União, inserindo proposições? (Média 2,79 e Desvio Padrão 2,08).

Dessa forma, o modelo atual de repasses de recursos não permite concluir que é possível a antecipação de programas passíveis para a realização de acordos e a elaboração de projetos de forma conjunta para a execução das politicas públicas a serem executadas de forma descentralizada, mediante os convênios com a União.

Relativo às respostas para o bloco "controle", obtivemos como respostas dos gestores distritais para as questões e1 a média e desvio padrão de 2,54 e 1,94, respectivamente, e f2, média de 2,54 e desvio de 1,81. Para os gestores municipais, obtivemos como respostas, sucessivamente, 1,82 e 1,51 e 2,00 e 1,12. Para ambos os grupos, as respostas levam a categoria (1 a 3 ) - Aplica-se pouco/baixo/ruim. Dessa forma, são baixas as percepções dos gestores distritais e municipais em relação às recomendações do controle interno para a melhoria da gestão e o apoio 
da alta administração do órgão distrital ou municipal de lotação para a melhora de desempenho.

Quanto às recomendações do controle externo e apoio da alta administração dos órgãos da União para a melhoria de desempenho dos recursos repassados, verificamos para o DF e munícipios também a baixa percepção quanto à preocupação da melhoria do processo. Nas respostas as questões e2 e f3, tivemos como médias distritais e desvios padrão, respectivamente, 2,54 e 1,98 e 2,62 e 1,19. Para os gestores municipais tivemos: 2,98 e 1,65 e 2,60 e 1,31.

Destaca-se a baixa percepção de ambos os grupos de gestores quanto ao acompanhamento da execução e prestação de contas dos recursos recebidos, por parte do controle interno (questão e4, DF: média 1,77 e desvio padrão de 1,48; municipais: média 1,66 e desvio de 1,29). Bem como, a observação quanto a quase inexistência de mecanismos e sistemas de acompanhamento físico-financeiro dos acordos (questão e7, DF: média 1,54 e desvio padrão1,13; municípios: média 1,10 e desvio de 1,02).

Em relação ao controle social, observamos que os gestores distritais e municipais atribuíram as médias respectivas de 1,15 e 0,71, com desvios de 1,14 e 0,71, em relação ao questionamento: e6 - As informações sobre a execução físicofinanceira estão disponíveis em tempo real para a população focal da política pública? Fato que pode estar impactando na possibilidade de acompanhamento e participação do controle social no processo de captação e execução dos recursos públicos da União executados por meio dos convênios da União com os entes federados, cujos servidores respondentes têm atividades (questão e5, DF: média 1,69 e desvio padrão de 1,49; municípios: média 0,79, desvio padrão de 0,79 ).

Corrobora essa afirmação o baixo score atribuído à questão e7 - Há mecanismos/sistema para o acompanhamento da execução físico/financeira pelas partes interessadas, além do sistema Siconv? Cuja média e desvio padrão para ambos os grupos de gestores situaram-se na categoria (1 a 3) - Aplica-se pouco/baixo/ruim (DF: média 1,54 e desvio padrão de 1,13; municípios, média 1,54 e desvio padrão de 1,10).

Em relação ao envolvimento das altas administrações distritais e municipais, os respondentes atribuíram uma baixa percepção em relação às questões f1 e f4, as quais abordam ambos os assuntos. As respectivas notas dos gestores distritais 
tiveram médias de 2,69 e 2,54, para tais questões. A atribuição das médias das notas dos gestores municipais foi de 2,21 e 2,61.

$\mathrm{Na}$ análise conjunta das questões $\mathrm{f} 2$ e $\mathrm{f} 4$, percebeu-se que para ambos os grupos de gestores que a alta administração da União e da alta administração dos órgãos de lotação dos gestores respondentes do questionário não estão envolvidos que a melhora no processo de execução dos recursos de transferências voluntárias, cujos scores ficaram abaixo da pontuação 3 , da categoria (1 a 3 ) - Aplica-se pouco/baixo/ruim.

Chama atenção a baixa nota em relação à resposta da questão f5 - As iniciativas e propostas para melhoria no processo de captação e execução de recursos são consideradas pela alta administração do seu órgão? Em que obtivemos uma média de ambos os grupos de gestores (DF: Média 2,23 e Desvio Padrão de 2,01; Municípios: Média 2,03 e Desvio Padrão de 1,38). Respostas às quais contribuem para a baixa nota em relação a percepções de envolvimento da alta administração no processo de captação e execução de recursos oriundos de transferências voluntárias da União.

Em relação às percepções dos gestores distritais e municipais quanto à tendência do processo de transferências voluntárias da união devido às características que o enquadrem ou ao planejamento (questões g5 e h3) ou a gestão (questões g6 e h4) ou ao controle (questões g7 e h5), verificamos que as maiores médias foram atribuídas ao "controle", seguido da "gestão", ficando assim com menor média o "planejamento", conforme demonstrado no Gráfico abaixo. 


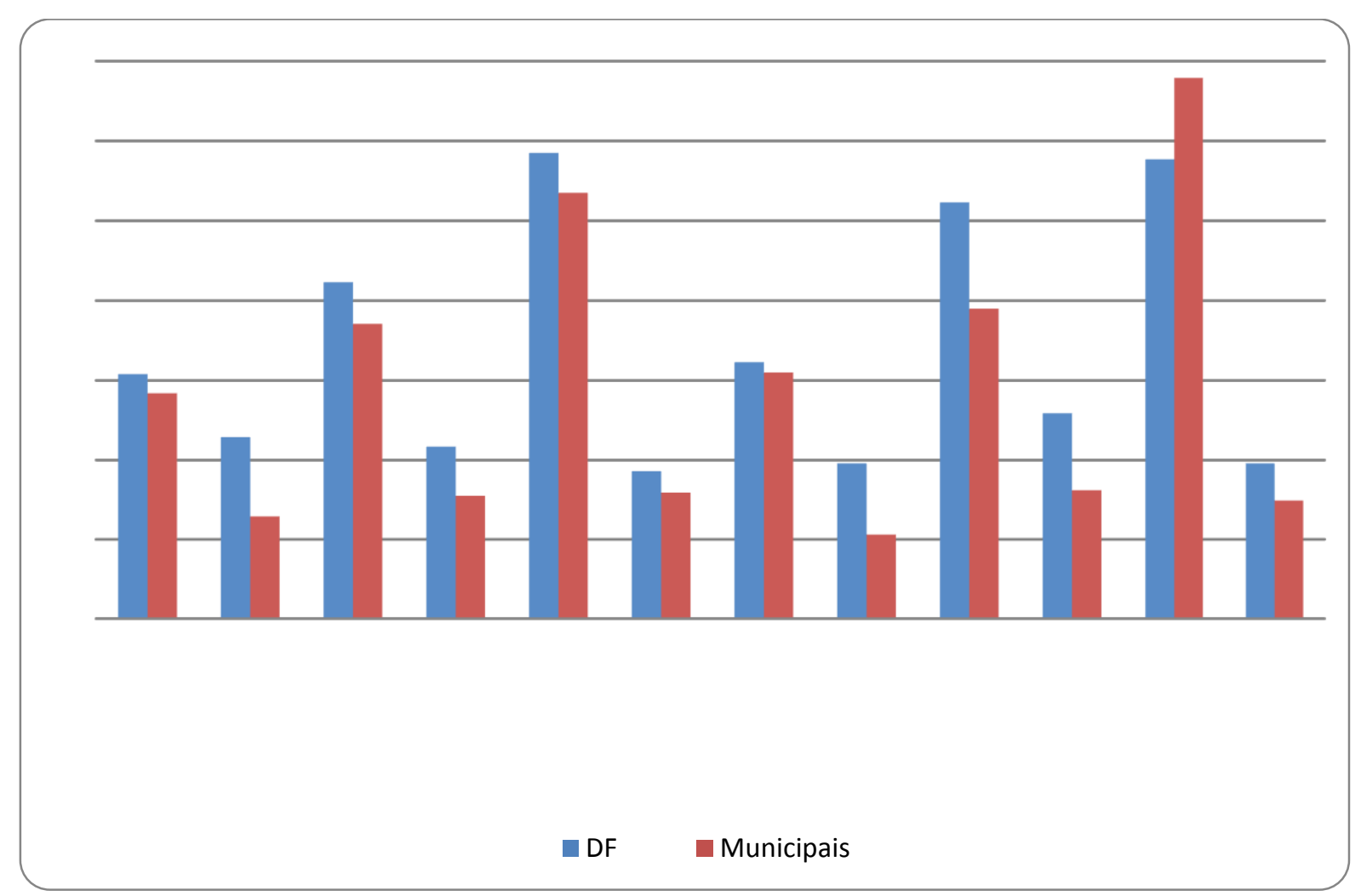

Gráfico 8 - Média e desvio padrão das respostas para as questões g5, g6, g7, h3, h4 e h5. Fonte: Elaborado pelo autor.

Finalmente, quanto ao bloco de questões em relação às percepções gerais, verificamos que o nível de dificuldade de operacionalização do sistema Siconv é alto. A média das notas de ambos os grupos de gestores, em relação a questão g8, situaram-se na categoria (4 a 7) - Sim, em parte/médio/bom, com médias de 7,38 e desvio padrão de 1,56, para os gestores distritais, e média 6,89 com um desvio de 1,56 , para os gestores municipais.

Quanto a classificação da sistemática de transferências dos recursos voluntários da União (questão h1), os gestores distritais percebem que o processo é bom, cuja média de notas enquadrou-se na categoria (4 a 7 ) - Sim, em parte/médio/bom. No entanto, para os gestores municipais a classificação é ruim, devido a obtenção de média de respostas de 2,82, para a mesma questão.

E a classificação quanto ao desempenho do órgão de lotação dos gestores distritais e municipais, respondentes do questionário, observamos que as médias das notas situaram-se na categoria (1 a 3) - Aplica-se pouco/baixo/ruim. 


\subsubsection{Análise da comparação das médias}

A intenção desta fase foi a de verificar se as médias das respostas dadas para as perguntas são iguais entre os gestores do DF e municipais, no intuito identificar se as percepções entre esses dois grupos são iguais ou não.

Para isso, o primeiro teste realizado foi à verificação da normalidade dos dados. Para a realização dos testes há de se fixar um erro, neste caso de 5\%. Logo, foram utilizados dois testes: Kolmogorov-Smirnov e Shapiro-Wilk, sendo este último o mais indicado. Assim, as hipóteses dos dois testes seguem abaixo:

A regra de decisão para a verificação da normalidade dos dados é: se $\circ$ pvalor associado for maior que o erro, a hipótese de normalidade dos dados é aceita; caso contrário, esta hipótese é rejeitada (os dados não possuem distribuição normal).

Hipótese nula $\left(\mathrm{H}_{0}\right)$ : Os dados possuem distribuição normal

Hipótese alternativa $\left(\mathrm{H}_{1}\right)$ : Os dados não possuem distribuição normal

A seguir, tem-se a Tabela 15 com os resultados para os testes de normalidade realizados. 
Tabela 15 - Testes de Normalidade Kolmogorv-Smirnov e Shapiro-Wilk (continua).

\begin{tabular}{|c|c|c|c|c|c|c|c|}
\hline \multirow{2}{*}{\multicolumn{2}{|c|}{ Entidades Públicas }} & \multicolumn{3}{|c|}{ Kolmogorov-Smirnov } & \multicolumn{3}{|c|}{ Shapiro-Wilk } \\
\hline & & Estatística & Município & $p$-valor & Estatística & Município & $p$-valor \\
\hline \multirow{2}{*}{ A1 } & Municipais & 0,303 & 62 & 0,000 & 0,759 & 62 & 0,000 \\
\hline & Distrital & 0,431 & 13 & 0,000 & 0,592 & 13 & 0,000 \\
\hline \multirow{2}{*}{ A2 } & Municipais & 0,271 & 62 & 0,000 & 0,795 & 62 & 0,000 \\
\hline & Distrital & 0,505 & 13 & 0,000 & 0,446 & 13 & 0,000 \\
\hline \multirow{2}{*}{ A3 } & Municipais & 0,280 & 62 & 0,000 & 0,798 & 62 & 0,000 \\
\hline & Distrital & 0,317 & 13 & 0,001 & 0,795 & 13 & 0,006 \\
\hline \multirow{2}{*}{ A4 } & Municipais & 0,328 & 62 & 0,000 & 0,754 & 62 & 0,000 \\
\hline & Distrital & 0,303 & 13 & 0,002 & 0,778 & 13 & 0,004 \\
\hline \multirow{2}{*}{ A5 } & Municipais & 0,414 & 62 & 0,000 & 0,665 & 62 & 0,000 \\
\hline & Distrital & 0,342 & 13 & 0,000 & 0,766 & 13 & 0,003 \\
\hline \multirow{2}{*}{ A6 } & Municipais & 0,269 & 62 & 0,000 & 0,779 & 62 & 0,000 \\
\hline & Distrital & 0,269 & 13 & 0,011 & 0,820 & 13 & 0,012 \\
\hline \multirow{2}{*}{ B1 } & Municipais & 0,319 & 62 & 0,000 & 0,747 & 62 & 0,000 \\
\hline & Distrital & 0,352 & 13 & 0,000 & 0,646 & 13 & 0,000 \\
\hline \multirow{2}{*}{ B2 } & Municipais & 0,259 & 62 & 0,000 & 0,786 & 62 & 0,000 \\
\hline & Distrital & 0,408 & 13 & 0,000 & 0,675 & 13 & 0,000 \\
\hline \multirow{2}{*}{ B3 } & Municipais & 0,366 & 62 & 0,000 & 0,729 & 62 & 0,000 \\
\hline & Distrital & 0,239 & 13 & 0,040 & 0,812 & 13 & 0,010 \\
\hline \multirow{2}{*}{ B4 } & Municipais & 0,340 & 62 & 0,000 & 0,718 & 62 & 0,000 \\
\hline & Distrital & 0,239 & 13 & 0,040 & 0,812 & 13 & 0,010 \\
\hline \multirow{2}{*}{ B5 } & Municipais & 0,447 & 62 & 0,000 & 0,569 & 62 & 0,000 \\
\hline & Distrital & 0,408 & 13 & 0,000 & 0,675 & 13 & 0,000 \\
\hline \multirow{2}{*}{ B6 } & Municipais & 0,328 & 62 & 0,000 & 0,732 & 62 & 0,000 \\
\hline & Distrital & 0,408 & 13 & 0,000 & 0,675 & 13 & 0,000 \\
\hline \multirow{2}{*}{ C1 } & Municipais & 0,276 & 62 & 0,000 & 0,781 & 62 & 0,000 \\
\hline & Distrital & 0,233 & 13 & 0,053 & 0,825 & 13 & 0,014 \\
\hline \multirow{2}{*}{ C2 } & Municipais & 0,278 & 62 & 0,000 & 0,785 & 62 & 0,000 \\
\hline & Distrital & 0,233 & 13 & 0,053 & 0,825 & 13 & 0,014 \\
\hline \multirow{2}{*}{ C3 } & Municipais & 0,411 & 62 & 0,000 & 0,666 & 62 & 0,000 \\
\hline & Distrital & 0,233 & 13 & 0,053 & 0,825 & 13 & 0,014 \\
\hline \multirow{2}{*}{ C4 } & Municipais & 0,420 & 62 & 0,000 & 0,652 & 62 & 0,000 \\
\hline & Distrital & 0,269 & 13 & 0,011 & 0,820 & 13 & 0,012 \\
\hline \multirow{2}{*}{ C5 } & Municipais & 0,416 & 62 & 0,000 & 0,646 & 62 & 0,000 \\
\hline & Distrital & 0,532 & 13 & 0,000 & 0,311 & 13 & 0,000 \\
\hline
\end{tabular}


Tabela 15 - Testes de Normalidade Kolmogorv-Smirnov e Shapiro-Wilk (continuação).

\begin{tabular}{|c|c|c|c|c|c|c|c|}
\hline \multirow{2}{*}{\multicolumn{2}{|c|}{ Entidades Públicas }} & \multicolumn{3}{|c|}{ Kolmogorov-Smirnov } & \multicolumn{3}{|c|}{ Shapiro-Wilk } \\
\hline & & Estatística & Município & $p$-valor & Estatística & Município & $p$-valor \\
\hline \multirow{2}{*}{ C6 } & Municipais & 0,359 & 62 & 0,000 & 0,735 & 62 & 0,000 \\
\hline & Distrital & 0,352 & 13 & 0,000 & 0,646 & 13 & 0,000 \\
\hline \multirow{2}{*}{$\mathrm{C} 7$} & Municipais & 0,352 & 62 & 0,000 & 0,744 & 62 & 0,000 \\
\hline & Distrital & 0,303 & 13 & 0,002 & 0,778 & 13 & 0,004 \\
\hline \multirow{2}{*}{ C8 } & Municipais & 0,470 & 62 & 0,000 & 0,532 & 62 & 0,000 \\
\hline & Distrital & 0,378 & 13 & 0,000 & 0,733 & 13 & 0,001 \\
\hline \multirow{2}{*}{ D1 } & Municipais & 0,332 & 62 & 0,000 & 0,763 & 62 & 0,000 \\
\hline & Distrital & 0,269 & 13 & 0,011 & 0,820 & 13 & 0,012 \\
\hline \multirow{2}{*}{ D2 } & Municipais & 0,432 & 62 & 0,000 & 0,656 & 62 & 0,000 \\
\hline & Distrital & 0,281 & 13 & 0,006 & 0,811 & 13 & 0,009 \\
\hline \multirow{2}{*}{ D3 } & Municipais & 0,387 & 62 & 0,000 & 0,705 & 62 & 0,000 \\
\hline & Distrital & 0,317 & 13 & 0,001 & 0,795 & 13 & 0,006 \\
\hline \multirow{2}{*}{ D4 } & Municipais & 0,493 & 62 & 0,000 & 0,483 & 62 & 0,000 \\
\hline & Distrital & 0,532 & 13 & 0,000 & 0,311 & 13 & 0,000 \\
\hline \multirow{2}{*}{ D5 } & Municipais & 0,366 & 62 & 0,000 & 0,676 & 62 & 0,000 \\
\hline & Distrital & 0,470 & 13 & 0,000 & 0,533 & 13 & 0,000 \\
\hline \multirow{2}{*}{ D6 } & Municipais & 0,365 & 62 & 0,000 & 0,725 & 62 & 0,000 \\
\hline & Distrital & 0,317 & 13 & 0,001 & 0,795 & 13 & 0,006 \\
\hline \multirow{2}{*}{ D7 } & Municipais & 0,337 & 62 & 0,000 & 0,756 & 62 & 0,000 \\
\hline & Distrital & 0,392 & 13 & 0,000 & 0,628 & 13 & 0,000 \\
\hline \multirow{2}{*}{ E1 } & Municipais & 0,311 & 62 & 0,000 & 0,778 & 62 & 0,000 \\
\hline & Distrital & 0,317 & 13 & 0,001 & 0,795 & 13 & 0,006 \\
\hline \multirow{2}{*}{ E2 } & Municipais & 0,283 & 62 & 0,000 & 0,757 & 62 & 0,000 \\
\hline & Distrital & 0,269 & 13 & 0,011 & 0,820 & 13 & 0,012 \\
\hline \multirow{2}{*}{ E3 } & Municipais & 0,416 & 62 & 0,000 & 0,635 & 62 & 0,000 \\
\hline & Distrital & 0,470 & 13 & 0,000 & 0,533 & 13 & 0,000 \\
\hline \multirow{2}{*}{ E4 } & Municipais & 0,387 & 62 & 0,000 & 0,701 & 62 & 0,000 \\
\hline & Distrital & 0,281 & 13 & 0,006 & 0,811 & 13 & 0,009 \\
\hline \multirow{2}{*}{ E5 } & Municipais & 0,381 & 62 & 0,000 & 0,627 & 62 & 0,000 \\
\hline & Distrital & 0,378 & 13 & 0,000 & 0,733 & 13 & 0,001 \\
\hline \multirow{2}{*}{ E6 } & Municipais & 0,373 & 62 & 0,000 & 0,631 & 62 & 0,000 \\
\hline & Distrital & 0,392 & 13 & 0,000 & 0,628 & 13 & 0,000 \\
\hline \multirow{2}{*}{ E7 } & Municipais & 0,414 & 62 & 0,000 & 0,605 & 62 & 0,000 \\
\hline & Distrital & 0,408 & 13 & 0,000 & 0,675 & 13 & 0,000 \\
\hline
\end{tabular}


Tabela 15 - Testes de Normalidade Kolmogorv-Smirnov e Shapiro-Wilk (continuação).

\begin{tabular}{|c|c|c|c|c|c|c|c|}
\hline \multirow{2}{*}{\multicolumn{2}{|c|}{ Entidades Públicas }} & \multicolumn{3}{|c|}{ Kolmogorov-Smirnov } & \multicolumn{3}{|c|}{ Shapiro-Wilk } \\
\hline & & Estatística & Município & $p$-valor & Estatística & Município & $p$-valor \\
\hline \multirow{2}{*}{$\mathrm{F} 1$} & Municipais & 0,389 & 62 & 0,000 & 0,683 & 62 & 0,000 \\
\hline & Distrital & 0,281 & 13 & 0,006 & 0,811 & 13 & 0,009 \\
\hline \multirow{2}{*}{ F2 } & Municipais & 0,403 & 62 & 0,000 & 0,609 & 62 & 0,000 \\
\hline & Distrital & 0,317 & 13 & 0,001 & 0,795 & 13 & 0,006 \\
\hline \multirow{2}{*}{ F3 } & Municipais & 0,407 & 62 & 0,000 & 0,676 & 62 & 0,000 \\
\hline & Distrital & 0,378 & 13 & 0,000 & 0,733 & 13 & 0,001 \\
\hline \multirow{2}{*}{ F4 } & Municipais & 0,475 & 62 & 0,000 & 0,542 & 62 & 0,000 \\
\hline & Distrital & 0,408 & 13 & 0,000 & 0,675 & 13 & 0,000 \\
\hline \multirow{2}{*}{ F5 } & Municipais & 0,339 & 62 & 0,000 & 0,751 & 62 & 0,000 \\
\hline & Distrital & 0,233 & 13 & 0,053 & 0,825 & 13 & 0,014 \\
\hline \multirow{2}{*}{ G1 } & Municipais & 0,414 & 62 & 0,000 & 0,665 & 62 & 0,000 \\
\hline & Distrital & 0,303 & 13 & 0,002 & 0,778 & 13 & 0,004 \\
\hline \multirow{2}{*}{ G2 } & Municipais & 0,408 & 62 & 0,000 & 0,654 & 62 & 0,000 \\
\hline & Distrital & 0,470 & 13 & 0,000 & 0,533 & 13 & 0,000 \\
\hline \multirow{2}{*}{ G3 } & Municipais & 0,359 & 62 & 0,000 & 0,737 & 62 & 0,000 \\
\hline & Distrital & 0,239 & 13 & 0,040 & 0,812 & 13 & 0,010 \\
\hline \multirow{2}{*}{ G4 } & Municipais & 0,447 & 62 & 0,000 & 0,569 & 62 & 0,000 \\
\hline & Distrital & 0,342 & 13 & 0,000 & 0,766 & 13 & 0,003 \\
\hline \multirow{2}{*}{ G5 } & Municipais & 0,431 & 62 & 0,000 & 0,589 & 62 & 0,000 \\
\hline & Distrital & 0,283 & 13 & 0,005 & 0,790 & 13 & 0,005 \\
\hline \multirow{2}{*}{ G6 } & Municipais & 0,414 & 62 & 0,000 & 0,605 & 62 & 0,000 \\
\hline & Distrital & 0,262 & 13 & 0,015 & 0,875 & 13 & 0,062 \\
\hline \multirow{2}{*}{ G7 } & Municipais & 0,433 & 62 & 0,000 & 0,624 & 62 & 0,000 \\
\hline & Distrital & 0,317 & 13 & 0,001 & 0,795 & 13 & 0,006 \\
\hline \multirow{2}{*}{ G8 } & Municipais & 0,356 & 62 & 0,000 & 0,635 & 62 & 0,000 \\
\hline & Distrital & 0,352 & 13 & 0,000 & 0,646 & 13 & 0,000 \\
\hline \multirow{2}{*}{$\mathrm{H} 1$} & Municipais & 0,361 & 62 & 0,000 & 0,720 & 62 & 0,000 \\
\hline & Distrital & 0,307 & 13 & 0,001 & 0,856 & 13 & 0,035 \\
\hline \multirow{2}{*}{$\mathrm{H} 2$} & Municipais & 0,336 & 62 & 0,000 & 0,751 & 62 & 0,000 \\
\hline & Distrital & 0,352 & 13 & 0,000 & 0,646 & 13 & 0,000 \\
\hline \multirow{2}{*}{ H3 } & Municipais & 0,398 & 62 & 0,000 & 0,618 & 62 & 0,000 \\
\hline & Distrital & 0,303 & 13 & 0,002 & 0,778 & 13 & 0,004 \\
\hline \multirow{2}{*}{$\mathrm{H} 4$} & Municipais & 0,406 & 62 & 0,000 & 0,612 & 62 & 0,000 \\
\hline & Distrital & 0,302 & 13 & 0,002 & 0,867 & 13 & 0,048 \\
\hline
\end{tabular}


Tabela 15 - Testes de Normalidade Kolmogorv-Smirnov e Shapiro-Wilk (conclusão).

\begin{tabular}{cccccccc}
\hline \multirow{2}{*}{ Entidades Públicas } & \multicolumn{3}{c}{ Kolmogorov-Smirnov } & \multicolumn{3}{c}{ Shapiro-Wilk } \\
\cline { 3 - 8 } & \multicolumn{2}{c}{ Estatística } & Município & $\boldsymbol{p}$-valor & Estatística & Município & $\boldsymbol{p}$-valor \\
\hline \multirow{2}{*}{ H5 } & Municipais & 0,381 & 62 & $\mathbf{0 , 0 0 0}$ & 0,627 & 62 & $\mathbf{0 , 0 0 0}$ \\
& Distrital & 0,346 & 13 & $\mathbf{0 , 0 0 0}$ & 0,754 & 13 & $\mathbf{0 , 0 0 2}$ \\
\hline
\end{tabular}

Fonte: Elaborado pelo autor.

Analisando a tabela verifica-se que não há casos onde a normalidade é verificada nos dois grupos, assumindo um erro de $5 \%$. Deste modo, a análise é feita utilizando o teste não-paramétrico de Mann-Whitney.

\subsubsection{Teste de comparação de medis deMann-Whitney}

O teste não-paramétrico de Mann-Whitney é utilizado para comparação de médias de dois grupos ou população independentes. A amostra foi dividida em dois grupos: gestores distritais e gestores municipais. O teste visou comparar se há diferença de comportamento do fator dentre os grupos. A hipótese nula do teste é que as médias (ou comportamento) são iguais nos dois grupos. A hipótese alternativa é que são diferentes nos dois grupos. Assumindo um erro de 5\%, decidese não rejeitar a hipótese nula se o p-valor for maior que o erro $(0,05)$. Por outro lado, decide-se aceitar a hipótese alternativa se o p-valor for menor que 0,05.

Neste sentido, quando da realização dos testes, chega-se à Tabela 16, a seguir. 
Tabela 16 - Resultados dos testes de comparação de médias (continua).

\begin{tabular}{|c|c|c|c|c|c|}
\hline Pergunta & $\begin{array}{l}\text { U de Mann- } \\
\text { Whitney }\end{array}$ & Wilcoxon W & $\mathbf{Z}$ & $p$-valor & Resultado \\
\hline a1 & 393,500 & 484,500 &,- 151 & 0,880 & Diferença não significativa \\
\hline a2 & 296,000 & 387,000 & $-1,686$ & 0,092 & Diferença não significativa \\
\hline a3 & 400,000 & 2353,000 &,- 047 & 0,963 & Diferença não significativa \\
\hline a4 & 385,000 & 2338,000 &,- 287 & 0,774 & Diferença não significativa \\
\hline a5 & 37,500 & 128,500 & $-5,870$ & 0,000 & Diferença significativa \\
\hline a6 & 313,000 & 404,000 & $-1,376$ & 0,169 & Diferença não significativa \\
\hline b1 & 359,000 & 2312,000 &,- 701 & 0,484 & Diferença não significativa \\
\hline b2 & 288,500 & 379,500 & $-1,764$ & 0,078 & Diferença não significativa \\
\hline b3 & 387,000 & 2340,000 &,- 261 & 0,794 & Diferença não significativa \\
\hline b4 & 312,000 & 403,000 & $-1,425$ & 0,154 & Diferença não significativa \\
\hline b5 & 22,000 & 113,000 & $-6,085$ & 0,000 & Diferença significativa \\
\hline b6 & 300,500 & 391,500 & $-1,655$ & 0,098 & Diferença não significativa \\
\hline c1 & 344,000 & 435,000 &,- 894 & 0,371 & Diferença não significativa \\
\hline c2 & 313,000 & 404,000 & $-1,384$ & 0,166 & Diferença não significativa \\
\hline c3 & 358,000 & 2311,000 &,- 753 & 0,451 & Diferença não significativa \\
\hline c4 & 353,000 & 2306,000 &,- 877 & 0,381 & Diferença não significativa \\
\hline c5 & 316,500 & 2269,500 & $-1,553$ & 0,120 & Diferença não significativa \\
\hline c6 & 310,000 & 2263,000 & $-1,529$ & 0,126 & Diferença não significativa \\
\hline c7 & 351,000 & 2304,000 &,- 851 & 0,395 & Diferença não significativa \\
\hline c8 & 23,500 & 114,500 & $-6,225$ & 0,000 & Diferença significativa \\
\hline d1 & 368,000 & 2321,000 &,- 565 & 0,572 & Diferença não significativa \\
\hline d2 & 201,500 & 292,500 & $-3,408$ & 0,001 & Diferença significativa \\
\hline d3 & 217,500 & 308,500 & $-2,965$ & 0,003 & Diferença significativa \\
\hline d4 & 0,000 & 91,000 & $-6,763$ & 0,000 & Diferença significativa \\
\hline d5 & 273,500 & 364,500 & $-2,080$ & 0,038 & Diferença significativa \\
\hline d6 & 350,500 & 2303,500 &,- 893 & 0,372 & Diferença não significativa \\
\hline d7 & 341,000 & 2294,000 & $-1,009$ & 0,313 & Diferença não significativa \\
\hline e1 & 367,500 & 2320,500 &,- 572 & 0,567 & Diferença não significativa \\
\hline e2 & 293,000 & 384,000 & $-1,706$ & 0,088 & Diferença não significativa \\
\hline e3 & 358,000 & 2311,000 &,- 777 & 0,437 & Diferença não significativa \\
\hline e4 & 390,000 & 481,000 &,- 222 & 0,825 & Diferença não significativa \\
\hline e5 & 309,000 & 2262,000 & $-1,544$ & 0,123 & Diferença não significativa \\
\hline e6 & 382,500 & 2335,500 &,- 335 & 0,738 & Diferença não significativa \\
\hline e7 & 302,000 & 2255,000 & $-1,726$ & 0,084 & Diferença não significativa \\
\hline
\end{tabular}


Tabela 16 - Resultados dos testes de comparação de médias (conclusão).

\begin{tabular}{c|c|c|c|c|c}
\hline Pergunta & $\begin{array}{c}\text { U de Mann- } \\
\text { Whitney }\end{array}$ & Wilcoxon W & $\mathbf{Z}$ & $\boldsymbol{p}$-valor & Resultado \\
\hline f1 & 369,000 & 2322,000 &,- 595 & $\mathbf{0 , 5 5 2}$ & Diferença não significativa \\
\hline f2 & 375,000 & 2328,000 &,- 536 & $\mathbf{0 , 5 9 2}$ & Diferença não significativa \\
\hline 33 & 390,000 & 481,000 &,- 229 & $\mathbf{0 , 8 1 9}$ & Diferença não significativa \\
\hline f4 & 373,500 & 464,500 &,- 594 & $\mathbf{0 , 5 5 2}$ & Diferença não significativa \\
\hline f5 & 363,000 & 454,000 &,- 650 & $\mathbf{0 , 5 1 5}$ & Diferença não significativa \\
\hline g1 & 351,000 & 2304,000 &,- 902 & $\mathbf{0 , 3 6 7}$ & Diferença não significativa \\
\hline $\mathbf{g 2}$ & 216,500 & 307,500 & $-3,197$ & $\mathbf{0 , 0 0 1}$ & Diferença significativa \\
\hline g3 & 392,000 & 2345,000 &,- 178 & $\mathbf{0 , 8 5 9}$ & Diferença não significativa \\
\hline $\mathbf{g 4}$ & 388,000 & 2341,000 &,- 262 & $\mathbf{0 , 7 9 3}$ & Diferença não significativa \\
\hline g5 & 389,000 & 2342,000 &,- 232 & $\mathbf{0 , 8 1 6}$ & Diferença não significativa \\
\hline g6 & 338,000 & 429,000 & $-1,063$ & $\mathbf{0 , 2 8 8}$ & Diferença não significativa \\
\hline g7 & 388,500 & 479,500 &,- 267 & $\mathbf{0 , 7 8 9}$ & Diferença não significativa \\
\hline g8 & 400,500 & 491,500 &,- 040 & $\mathbf{0 , 9 6 8}$ & Diferença não significativa \\
\hline h1 & 294,000 & 2247,000 & $-1,736$ & $\mathbf{0 , 0 8 3}$ & Diferença não significativa \\
\hline h2 & 329,500 & 2282,500 & $-1,183$ & $\mathbf{0 , 2 3 7}$ & Diferença não significativa \\
\hline h3 & 383,000 & 474,000 &,- 328 & $\mathbf{0 , 7 4 3}$ & Diferença não significativa \\
\hline h4 & 350,000 & 2303,000 &,- 870 & $\mathbf{0 , 3 8 5}$ & Diferença não significativa \\
\hline h5 & 260,000 & 351,000 & $-2,339$ & $\mathbf{0 , 0 1 9}$ & Diferença significativa \\
\hline
\end{tabular}

Fonte: Elaborado pelo autor.

Analisando a tabela, observa-se que há diferenças entre as médias para os dois grupos de gestores nas perguntas a5, b5, c8, d2, d3, d4, d5, g2 e h5, assumindo um erro de $5 \%$.

Observou-se ainda na tabela que em todos os casos o escore $Z$ é negativo. Como o valor de referência foi o grupo dos gestores distritais, o cálculo foi feito visando à comparação do escore médio distrital menos o escore médio municipal. Assim, podemos gerar as seguintes hipóteses:

Hipótese nula $\left(\mathrm{H}_{0}\right)$ : A média populacional é igual para os dois grupos

Hipótese alternativa $\left(H_{1}\right)$ : A média populacional é maior nos Municípios que no Distrito Federal 
Assumindo um erro de 5\%, decide-se não rejeitar a hipótese nula se o p-valor for maior que o erro $(0,05)$. Por outro lado, decide-se aceitar a hipótese alternativa se o p-valor for menor que 0,05 . A seguir, tem-se a Tabela 17 , com os dados recalculados.

Tabela 17 - Recálculo de comparação do score médio distrital menos o score médio municipal (continua).

\begin{tabular}{|c|c|c|c|c|c|}
\hline Pergunta & $\begin{array}{l}\text { U de Mann- } \\
\text { Whitney }\end{array}$ & Wilcoxon W & $\mathbf{Z}$ & $p$-valor & Resultado \\
\hline a1 & 393,500 & 484,500 &,- 151 & 0,440 & Diferença não significativa \\
\hline a2 & 296,000 & 387,000 & $-1,686$ & 0,046 & Diferença significativa \\
\hline a3 & 400,000 & 2353,000 &,- 047 & 0,481 & Diferença não significativa \\
\hline a4 & 385,000 & 2338,000 &,- 287 & 0,387 & Diferença não significativa \\
\hline a5 & 37,500 & 128,500 & $-5,870$ & 0,000 & Diferença significativa \\
\hline a6 & 313,000 & 404,000 & $-1,376$ & 0,084 & Diferença não significativa \\
\hline b1 & 359,000 & 2312,000 &,- 701 & 0,242 & Diferença não significativa \\
\hline b2 & 288,500 & 379,500 & $-1,764$ & 0,039 & Diferença significativa \\
\hline b3 & 387,000 & 2340,000 &,- 261 & 0,397 & Diferença não significativa \\
\hline b4 & 312,000 & 403,000 & $-1,425$ & 0,077 & Diferença não significativa \\
\hline b5 & 22,000 & 113,000 & $-6,085$ & 0,000 & Diferença significativa \\
\hline b6 & 300,500 & 391,500 & $-1,655$ & 0,049 & Diferença significativa \\
\hline $\mathrm{c} 1$ & 344,000 & 435,000 &,- 894 & 0,186 & Diferença não significativa \\
\hline c2 & 313,000 & 404,000 & $-1,384$ & 0,083 & Diferença não significativa \\
\hline c3 & 358,000 & 2311,000 &,- 753 & 0,226 & Diferença não significativa \\
\hline c4 & 353,000 & 2306,000 &,- 877 & 0,190 & Diferença não significativa \\
\hline c5 & 316,500 & 2269,500 & $-1,553$ & 0,060 & Diferença não significativa \\
\hline c6 & 310,000 & 2263,000 & $-1,529$ & 0,063 & Diferença não significativa \\
\hline c7 & 351,000 & 2304,000 &,- 851 & 0,197 & Diferença não significativa \\
\hline $\mathrm{c} 8$ & 23,500 & 114,500 & $-6,225$ & 0,000 & Diferença significativa \\
\hline d1 & 368,000 & 2321,000 &,- 565 & 0,286 & Diferença não significativa \\
\hline $\mathrm{d} 2$ & 201,500 & 292,500 & $-3,408$ & 0,000 & Diferença significativa \\
\hline d3 & 217,500 & 308,500 & $-2,965$ & 0,002 & Diferença significativa \\
\hline $\mathrm{d} 4$ & 0,000 & 91,000 & $-6,763$ & 0,000 & Diferença significativa \\
\hline d5 & 273,500 & 364,500 & $-2,080$ & 0,019 & Diferença significativa \\
\hline d6 & 350,500 & 2303,500 &,- 893 & 0,186 & Diferença não significativa \\
\hline d7 & 341,000 & 2294,000 & $-1,009$ & 0,157 & Diferença não significativa \\
\hline
\end{tabular}


Tabela 17 - Recálculo de comparação do score médio distrital menos o score médio municipal (conclusão).

\begin{tabular}{|c|c|c|c|c|c|}
\hline Pergunta & $\begin{array}{l}\text { U de Mann- } \\
\text { Whitney }\end{array}$ & Wilcoxon W & $\mathbf{Z}$ & $p$-valor & Resultado \\
\hline e1 & 367,500 & 2320,500 &,- 572 & 0,284 & Diferença não significativa \\
\hline e2 & 293,000 & 384,000 & $-1,706$ & 0,044 & Diferença significativa \\
\hline e3 & 358,000 & 2311,000 &,- 777 & 0,219 & Diferença não significativa \\
\hline e4 & 390,000 & 481,000 &,- 222 & 0,412 & Diferença não significativa \\
\hline e5 & 309,000 & 2262,000 & $-1,544$ & 0,061 & Diferença não significativa \\
\hline e6 & 382,500 & 2335,500 &,- 335 & 0,369 & Diferença não significativa \\
\hline e7 & 302,000 & 2255,000 & $-1,726$ & 0,042 & Diferença significativa \\
\hline $\mathrm{f} 1$ & 369,000 & 2322,000 &,- 595 & 0,276 & Diferença não significativa \\
\hline 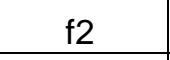 & 375,000 & 2328,000 &,- 536 & 0,296 & Diferença não significativa \\
\hline $\mathrm{f} 3$ & 390,000 & 481,000 &,- 229 & 0,410 & Diferença não significativa \\
\hline $\mathrm{f} 4$ & 373,500 & 464,500 &,- 594 & 0,276 & Diferença não significativa \\
\hline $\mathrm{f} 5$ & 363,000 & 454,000 &,- 650 & 0,258 & Diferença não significativa \\
\hline$g 1$ & 351,000 & 2304,000 &,- 902 & 0,183 & Diferença não significativa \\
\hline g2 & 216,500 & 307,500 & $-3,197$ & 0,001 & Diferença significativa \\
\hline g3 & 392,000 & 2345,000 &,- 178 & 0,429 & Diferença não significativa \\
\hline$g 4$ & 388,000 & 2341,000 &,- 262 & 0,397 & Diferença não significativa \\
\hline g5 & 389,000 & 2342,000 &,- 232 & 0,408 & Diferença não significativa \\
\hline$g 6$ & 338,000 & 429,000 & $-1,063$ & 0,144 & Diferença não significativa \\
\hline g7 & 388,500 & 479,500 &,- 267 & 0,395 & Diferença não significativa \\
\hline g8 & 400,500 & 491,500 &,- 040 & 0,484 & Diferença não significativa \\
\hline h1 & 294,000 & 2247,000 & $-1,736$ & 0,041 & Diferença significativa \\
\hline h2 & 329,500 & 2282,500 & $-1,183$ & 0,118 & Diferença não significativa \\
\hline h3 & 383,000 & 474,000 &,- 328 & 0,371 & Diferença não significativa \\
\hline h4 & 350,000 & 2303,000 &,- 870 & 0,192 & Diferença não significativa \\
\hline h5 & 260,000 & 351,000 & $-2,339$ & 0,010 & Diferença significativa \\
\hline
\end{tabular}

Fonte: Elaborado pelo autor.

\subsubsection{Análise de correlação}

A análise de Correlação Linear entre as duas variáveis primeiramente depende da distribuição dos dados estudados. Se as duas variáveis possuírem distribuição de probabilidade normal, poderá ser utilizado o teste de correlação linear que tem como base a correlação linear de Pearson. Caso contrário, assumindo-se 
que as variáveis não possuem distribuição de probabilidade normal, o teste utilizado é não-paramétrico e tem como referência a correlação de Spearman.

Para a realização dos testes de normalidade fixou-se um erro, neste caso de $5 \%$. Sendo realizados dois testes: Kolmogorov-Smirnov e Shapiro-Wilk, sendo este último o mais indicado, devido ao comportamento das respostas. Assim, as hipóteses dos dois testes seguem abaixo:

Hipótese nula $\left(\mathrm{H}_{0}\right)$ : Os dados possuem distribuição normal

Hipótese alternativa $\left(\mathrm{H}_{1}\right)$ : Os dados não possuem distribuição normal

A regra de decisão para a verificação da normalidade dos dados é: se o $p$ valor associado for maior que o erro, a hipótese de normalidade dos dados é aceita; caso contrário, esta hipótese é rejeitada (os dados não possuem distribuição normal).

Tabela 18 - Teste de normalidade (continua).

\begin{tabular}{ccccccc}
\hline \multirow{2}{*}{ Variável } & \multicolumn{3}{c}{ Kolmogorov-Smirnov } & \multicolumn{3}{c}{ Shapiro-Wilk } \\
\cline { 2 - 7 } & Estatística & Df & P-valor & Estatística & df & P-valor \\
\hline A1 & 0,19 & 75 & 0,00 & 0,93 & 75 & 0,00 \\
A2 & 0,18 & 75 & 0,00 & 0,93 & 75 & 0,00 \\
A3 & 0,17 & 75 & 0,00 & 0,92 & 75 & 0,00 \\
A4 & 0,17 & 75 & 0,00 & 0,95 & 75 & 0,01 \\
A5 & 0,21 & 75 & 0,00 & 0,87 & 75 & 0,00 \\
A6 & 0,15 & 75 & 0,00 & 0,93 & 75 & 0,00 \\
b1 & 0,18 & 75 & 0,00 & 0,94 & 75 & 0,00 \\
b2 & 0,14 & 75 & 0,00 & 0,92 & 75 & 0,00 \\
b3 & 0,17 & 75 & 0,00 & 0,93 & 75 & 0,00 \\
b4 & 0,13 & 75 & 0,00 & 0,95 & 75 & 0,01 \\
b5 & 0,26 & 75 & 0,00 & 0,82 & 75 & 0,00 \\
b6 & 0,18 & 75 & 0,00 & 0,94 & 75 & 0,00 \\
c1 & 0,14 & 75 & 0,00 & 0,92 & 75 & 0,00 \\
c2 & 0,14 & 75 & 0,00 & 0,94 & 75 & 0,00 \\
c3 & 0,16 & 75 & 0,00 & 0,87 & 75 & 0,00 \\
\hline
\end{tabular}


Tabela 18 - Teste de normalidade (continuação).

\begin{tabular}{|c|c|c|c|c|c|c|}
\hline \multirow{2}{*}{ Variável } & \multicolumn{3}{|c|}{ Kolmogorov-Smirnov } & \multicolumn{3}{|c|}{ Shapiro-Wilk } \\
\hline & Estatística & Df & P-valor & Estatística & df & P-valor \\
\hline c4 & 0,18 & 75 & 0,00 & 0,90 & 75 & 0,00 \\
\hline c5 & 0,24 & 75 & 0,00 & 0,87 & 75 & 0,00 \\
\hline c6 & 0,15 & 75 & 0,00 & 0,95 & 75 & 0,00 \\
\hline c7 & 0,17 & 75 & 0,00 & 0,95 & 75 & 0,00 \\
\hline $\mathrm{c} 8$ & 0,25 & 75 & 0,00 & 0,85 & 75 & 0,00 \\
\hline d1 & 0,17 & 75 & 0,00 & 0,90 & 75 & 0,00 \\
\hline d2 & 0,22 & 75 & 0,00 & 0,94 & 75 & 0,00 \\
\hline d3 & 0,19 & 75 & 0,00 & 0,94 & 75 & 0,00 \\
\hline $\mathrm{d} 4$ & 0,19 & 75 & 0,00 & 0,90 & 75 & 0,00 \\
\hline d5 & 0,16 & 75 & 0,00 & 0,94 & 75 & 0,00 \\
\hline d6 & 0,18 & 75 & 0,00 & 0,92 & 75 & 0,00 \\
\hline $\mathrm{d} 7$ & 0,22 & 75 & 0,00 & 0,92 & 75 & 0,00 \\
\hline e1 & 0,20 & 75 & 0,00 & 0,91 & 75 & 0,00 \\
\hline e2 & 0,18 & 75 & 0,00 & 0,91 & 75 & 0,00 \\
\hline e3 & 0,18 & 75 & 0,00 & 0,94 & 75 & 0,00 \\
\hline e4 & 0,20 & 75 & 0,00 & 0,90 & 75 & 0,00 \\
\hline e5 & 0,24 & 75 & 0,00 & 0,81 & 75 & 0,00 \\
\hline e6 & 0,26 & 75 & 0,00 & 0,81 & 75 & 0,00 \\
\hline e7 & 0,21 & 75 & 0,00 & 0,87 & 75 & 0,00 \\
\hline $\mathrm{f} 1$ & 0,24 & 75 & 0,00 & 0,91 & 75 & 0,00 \\
\hline f2 & 0,20 & 75 & 0,00 & 0,93 & 75 & 0,00 \\
\hline $\mathrm{f} 3$ & 0,18 & 75 & 0,00 & 0,94 & 75 & 0,00 \\
\hline $\mathrm{f} 4$ & 0,20 & 75 & 0,00 & 0,93 & 75 & 0,00 \\
\hline f5 & 0,20 & 75 & 0,00 & 0,92 & 75 & 0,00 \\
\hline g1 & 0,15 & 75 & 0,00 & 0,95 & 75 & 0,01 \\
\hline g2 & 0,13 & 75 & 0,00 & 0,97 & 75 & 0,05 \\
\hline g3 & 0,24 & 75 & 0,00 & 0,91 & 75 & 0,00 \\
\hline g4 & 0,19 & 75 & 0,00 & 0,85 & 75 & 0,00 \\
\hline g5 & 0,28 & 75 & 0,00 & 0,90 & 75 & 0,00 \\
\hline g6 & 0,16 & 75 & 0,00 & 0,94 & 75 & 0,00 \\
\hline g7 & 0,22 & 75 & 0,00 & 0,91 & 75 & 0,00 \\
\hline g8 & 0,19 & 75 & 0,00 & 0,93 & 75 & 0,00 \\
\hline h1 & 0,22 & 75 & 0,00 & 0,93 & 75 & 0,00 \\
\hline h2 & 0,24 & 75 & 0,00 & 0,91 & 75 & 0,00 \\
\hline
\end{tabular}


Tabela 18 - Teste de normalidade (conclusão).

\begin{tabular}{ccccccc}
\hline \multirow{2}{*}{ Variável } & \multicolumn{3}{c}{ Kolmogorov-Smirnov } & \multicolumn{3}{c}{ Shapiro-Wilk } \\
\cline { 2 - 7 } & Estatística & Df & P-valor & Estatística & df & P-valor \\
\hline h3 & 0,17 & 75 & 0,00 & 0,94 & 75 & 0,00 \\
h4 & 0,14 & 75 & 0,00 & 0,95 & 75 & 0,00 \\
h5 & 0,20 & 75 & 0,00 & 0,92 & 75 & 0,00 \\
\hline
\end{tabular}

Fonte: Elaborado pelo autor.

Deste modo, verifica-se que não há normalidade em nenhuma das variáveis. Assim, serão feitos testes não-paramétricos de correlação de Spearman. Este teste tem as seguintes hipóteses:

Hipótese nula $\left(\mathrm{H}_{0}\right)$ : Não há correlação entre as variáveis na população

Hipótese alternativa $\left(\mathrm{H}_{1}\right)$ : Há correlação entre as variáveis na população (positiva ou negativa)

Se o p-valor for menor que o erro assumido, há indícios de correlação entre as variáveis na população. Caso contrário, não se pode afirmar que há correlação entre as variáveis na população. A seguir, tem-se a Tabela 19, com os resultados. 
Tabela 19 - Resultados dos testes de correlação.

\begin{tabular}{|c|c|c|c|}
\hline Correlação & P-valor & Sinal da Correlação & Correlação amostral \\
\hline$a 1 \times b 1$ & 0,00 & Positivo & 0,96 \\
\hline $\mathrm{a} 2 \times \mathrm{b} 2$ & 0,00 & Positivo & 0,92 \\
\hline$a 3 \times b 3$ & 0,00 & Positivo & 0,94 \\
\hline $\mathrm{a} 4 \times \mathrm{b} 4$ & 0,00 & Positivo & 0,58 \\
\hline a5 $\times$ b5 & 0,00 & Positivo & 0,59 \\
\hline$a 6 \times b 6$ & 0,00 & Positivo & 0,91 \\
\hline$c 1 \times c 3$ & 0,00 & Positivo & 0,37 \\
\hline $\mathrm{c} 2 \mathrm{x} \mathrm{d} 3$ & 0,01 & Positivo & 0,31 \\
\hline$c 4 \times c 5$ & 0,70 & Negativo & $-0,05$ \\
\hline $\mathrm{c} 6 \mathrm{x} \mathrm{d} 5$ & 0,38 & Negativo & $-0,10$ \\
\hline $\mathrm{c} 8 \times \mathrm{d} 4$ & 0,00 & Positivo & 0,80 \\
\hline $\mathrm{d} 1 \mathrm{x} \mathrm{d} 4$ & 0,34 & Negativo & $-0,11$ \\
\hline $\mathrm{d} 6 \times \mathrm{g} 4$ & 0,22 & Positivo & 0,14 \\
\hline$e 1 \times f 2$ & 0,46 & Positivo & 0,09 \\
\hline$e 2 \times f 3$ & 0,94 & Positivo & 0,01 \\
\hline e $4 \times$ e7 & 0,00 & Positivo & 0,33 \\
\hline e $5 \times$ e 6 & 0,02 & Positivo & 0,46 \\
\hline e $5 \times$ e 7 & 0,08 & Positivo & 0,20 \\
\hline$f 1 \times f 4$ & 0,02 & Positivo & 0,28 \\
\hline $\mathrm{f} 2 \mathrm{x} f 4$ & 0,02 & Positivo & 0,27 \\
\hline$g 1 \times g 6$ & 0,00 & Positivo & $-0,21$ \\
\hline $\mathrm{g} 2 \times \mathrm{g} 7$ & 0,07 & Negativo & $-0,14$ \\
\hline g3 x g5 & 0,05 & Positivo & 0,23 \\
\hline $95 \times$ h3 & 0,01 & Positivo & 0,30 \\
\hline g6 6 h4 & 0,00 & Positivo & 0,65 \\
\hline g7 x h5 & 0,44 & Negativo & $-0,09$ \\
\hline
\end{tabular}

Fonte: Elaborado pelo autor.

As correlações cujos p-valores associados estão em destaque são as que possuem este valor menor que o erro de 5\%. Deste modo, há indícios que haja correlação entre estas variáveis destacadas na população, conforme apontado na Tabela 20, a seguir. 
Tabela 20 - Correlação entre as variáveis.

\begin{tabular}{|c|c|c|}
\hline Correlação & p-valor & Sinal da Correlação \\
\hline $\mathrm{a} 1 \mathrm{x}$ b1 & 0,00 & Positivo \\
\hline $\mathrm{a} 2 \times \mathrm{b} 2$ & 0,00 & Positivo \\
\hline$a 3 \times b 3$ & 0,00 & Positivo \\
\hline $\mathrm{a} 4 \times \mathrm{b} 4$ & 0,00 & Positivo \\
\hline$a 5 \times b 5$ & 0,00 & Positivo \\
\hline$a 6 \times b 6$ & 0,00 & Positivo \\
\hline$c 1 \times c 3$ & 0,00 & Positivo \\
\hline $\mathrm{c} 2 \mathrm{x} \mathrm{d} 3$ & 0,00 & Positivo \\
\hline $\mathrm{c} 8 \times \mathrm{d} 4$ & 0,00 & Positivo \\
\hline $\mathrm{e} 4 \times \mathrm{e} 7$ & 0,00 & Positivo \\
\hline e $5 \times$ e 6 & 0,01 & Positivo \\
\hline e $5 \times$ e 7 & 0,04 & Positivo \\
\hline $\mathrm{f} 1 \mathrm{xf} 4$ & 0,01 & Positivo \\
\hline $\mathrm{f} 2 \times \mathrm{f} 4$ & 0,01 & Positivo \\
\hline$g 1 \times g 6$ & 0,00 & Positivo \\
\hline g2 $\times g 7$ & 0,04 & Negativo \\
\hline g3 x g5 & 0,02 & Positivo \\
\hline g5 $x$ h3 & 0,00 & Positivo \\
\hline $\mathrm{g} 6 \times \mathrm{h} 4$ & 0,00 & Positivo \\
\hline
\end{tabular}

Fonte: Elaborado pelo autor.

Se realizarmos testes unilaterais, verificamos que há evidências de assumir que há uma correlação população positiva na população entre as variáveis acima, exceto para o caso da comparação entre as variáveis g2 e g7. Pelo fato que concluirmos que gestores distritais e municipais, respondentes dos questionários, pactuam em grande maioria das mesmas percepções quanto ao processo de transferências de recursos voluntários da União. 


\section{CONSIDERAÇÕES FINAIS}

A presente pesquisa buscou levantar elementos que permitissem a análise sobre as transferências voluntárias do orçamento fiscal e da seguridade social da União para as diversas entidades recebedoras, em vista de execução de políticas públicas de interesses recíprocos.

Após o levantamento bibliográfico relacionado ao federalismo fiscal, repartição de competências, relações interorganizacionais, planejamento orçamentário, gestão e controle, a análise foi realizada com duas vertentes metodológicas, uma de cunho quantitativo e outra qualitativa.

Por meio da análise quantitativa, em relação às características gerais dos repasses, verificamos que as transferências voluntárias de recursos da União movimentaram no período de 2008 a 2015 a quantia por volta de $\mathrm{R} \$ 80,507$ bilhões, com repasses da União de cerca de $R \$ 71,728$ bilhões aos diversos entes federados e instituições privadas sem fins lucrativos, para o fornecimento de bens e serviços a população focal dos acordos.

Em relação à quantidade de acordos realizados no período de 2008 a 2015, do total de 97.311 , cerca de $76 \%$ foram pactuadas com as administrações municipais, em detrimento as administrações estaduais, Distrital, consórcios públicos, empresas públicas e entidades privadas sem fins lucrativos.

Essa última constatação corrobora com a afirmação de que a dimensão local vem sendo revalorizada, no contexto da descentralização e de reforma do Estado, conferido aos municípios novos papeis e assunção de obrigações que outrora estavam a cargo do poder central.

No entanto, no que tange aos preceitos da NGP as descentralizações de recursos e funções para entidades privadas sem fins lucrativos não vem sendo fomentada pelo poder público federal, dessa forma, em referencia as transferências voluntarias, as parceiras com entidades privadas sem fins lucrativos vem sendo deixadas a margem da execução das políticas públicas, contrariando o que é defendido por aquele conjunto teórico.

Em relação ao faixa de valor, verificamos que $70 \%$ dos acordos estão relacionados a projetos e atividades de valores inferiores a $\mathrm{R} \$ 500$ mil reais.

Detalhando os dados de execução, foi possível observar que 14.472 acordos estão em atrasos na execução, no que representou o valor global de $R \$ 10,331$ bilhões 
que ainda não atingiram os objetivos definidos nos planos de trabalhos pactuados entre as diversas entidades subnacionais para com a União, em benefício para a sociedade.

Ainda, verificamos que 2.934 acordos tiveram os recursos não executados e foram devolvidos a União, representando uma quantia de $R \$ 2,213$ bilhões de repasse da União, e significando um valor global $R$ \$2,498 bilhões de inexecução dos acordos de parceria entre os diversos participes.

Em relação às prestações de contas dos recursos executados, verificamos o atraso na prestação de contas de 19.858 acordos na soma global de $R \$ 17,846$ bilhões, com repasses de $R \$ 15,899$ bilhões por parte dos órgãos federais a estados, municípios, DF e instituições privadas sem fins lucrativos.

Derivado dos atrasos na execução ou na prestação de contas, os recursos depositados em caderneta de poupança em instituições financeiras federais, conforme determina a legislação aplicável, tiveram uma perda do poder de compra de 2,91\% no período de 04/05/2012 a 31/05/2016.

Tais fatos acabaram por influenciar com as percepções levantadas na análise qualitativa apresentada na Tabela 23, segundo método de análise, em que a maior parte das respostas aos questionamentos, tanto para os gestores distritais quanto municipais, apresentaram baixos scores quanto à percepção de um processo planejado e coordenado de repasses dos recursos federais as diversas entidades receptoras dos recursos, que permita uma boa utilização dos recursos financeiros disponíveis.

De acordo com essa segunda fase da análise, e em atendimento aos objetivos específicos da pesquisa, os seguintes resultados foram obtidos:

- O atual sistema, segundo as respostas dos 75 respondentes, não permite a antecipação de programas para a pactuação de acordos, devido ou a falta de canais de comunicação efetivos nas fases de elaboração dos instrumentos de planejamento da União ou por carência de conhecimento adequado por parte dos gestores municipais quanto ao processo de elaboração do planejamento federal.

- Existe a percepção da necessidade de maior envolvimento dos órgãos federais nas fases de elaboração, execução e prestação de contas, para que os recursos federais possam geridos no sentido de entrega dos produtos das politica públicas as populações focais dos objetos dos acordos.

- Assim como, há percepções da necessidade de maior apoio da cúpula administrativa de ambos os participes para a melhoria no processo de transferências e captação, execução e prestação de contas dos recursos. 
- Em relação às percepções dos gestores distritais e municipais quanto à tendência do processo de transferências voluntárias para o planejamento, gestão ou ao controle, foi possível identificar que os maiores scores foram atribuídos à sensação de controle no processo de transferências voluntárias, seguido da gestão. Dessa forma, segundo as percepções levantadas, o processo está pendente para o controle.

- Há baixa percepção em relação a processos, sistemas, canais de comunicação que permita o controle social participar dos inter-relacionamentos entre União e as entidades públicas para a formatação e execução dos planos de trabalho.

Importante mencionar que os testes estatísticos de significância, apesar da inexistência de uma distribuição normal relacionada às respostas dos gestores distritais e municipais, apresentaram evidências que há uma correlação positiva entre as respostas entre ambos os grupos de gestores.

Dessa forma, com base nas análises quantitativa e qualitativa realizadas, não identificamos elementos suficientes para concluir que as descentralizações de recursos e responsabilidades da União são melhores do que se fossem realizadas de forma direta por parte da União. Ou seja, os estados, municípios, Distrito Federal e entidades privadas sem fins lucrativos não oferecem de forma eficiente bens e serviços à sociedade por meio das transferências voluntárias da União, devido à série de desajustes no processo de planejamento, gestão e controle evidenciados nesta pesquisa.

Diante disso, tendo a União um alto poder de indução na formulação de políticas públicas, devido à relativa centralização do quantum tributário, impõe aos seus órgãos à necessidade de agir com maior planejamento e coordenação. Haja vista sua estratégia de atuação de descentralizar parcelas de recursos financeiros as entidades subnacionais para o atendimento das competências compartilhadas,

$E$, dessa forma, não apenas oferecer o suporte financeiro para a implementação das políticas públicas na forma dos repasses via transferências voluntárias.

Sendo assim, é necessário que a União forneça melhores canais de comunicação no processo de orçamentação pública para que os entes subnacionais e entidades privadas sem fins lucrativos possam atuar como futuros parceiros na execução das políticas públicas (evidenciados baixos scores quanto bloco de questões sobre o Planejamento orçamentário, categorizados em 1 a 3 - aplica-se pouco/baixo/ruim). 
Realizar programas de treinamento para os setoriais estaduais e municipais para o melhor entendimento do processo de orçamentação pública, melhores interacionamentos para a elaboração de projetos e monitoramento da execução e prestação de contas (evidenciados baixos scores quanto bloco de questões sobre a Gestão, categorizados em 1 a 3 - aplica-se pouco/baixo/ruim).

Promover eventos para a difusão do conhecimento e de boas práticas de gestão (evidenciados médios scores quanto bloco de questões gerais, categorizados em 1 a 3 aplica-se pouco/baixo/ruim, no sentido de notas que remetem a dificuldades dos gestores receptores dos recursos em compartilhar conhecimentos relacionados à melhoria da gestão).

Ampliar treinamentos para a operacionalização dos sistemas de tecnologia da informação da União, relacionadas às transferências voluntárias, sobretudo o Sistema Siconv (respostas categorizadas de 4-7 - evidenciados scores de média em relação à dificuldade em operar os sistemas relacionados à gestão dos convênios e congêneres).

A contraparte dos parceiros públicos seria a lotação de servidores com perfis adequados para gerir os recursos de transferências, os quais tenham formação correspondente ao planejamento, à gestão e ao controle.

$E$, quanto às ações de controle, que os órgãos de competência busquem atuar de forma a auxiliar a gestão dos órgãos responsáveis pela gestão dos recursos voluntários da União, com a ampliação das auditorias operacionais, fato que na pesquisa, pelos 75 respondentes, foram atribuídas baixas notas quanto à percepção da atividade de controle sobre a execução dos acordos. Mesmo que para eles o processo de repasses dos recursos tenha tendência de controle, conforme demonstrado nas respostas às questões h3, h4 e h5.

Portanto, é fundamental que se encontre canais efetivos e ações de planejamento, gestão e controle para permitir que as diversas entidades, públicas ou privadas, tenham maior poder de alocação, gestão e atendimento das demandas a nível local, nos objetos das políticas públicas realizadas de forma conjunta com a União. 


\section{REFERÊNCIAS}

ABRUCIO, Fernando Luiz; LOUREIRO, Maria Rita. Finanças públicas, democracia e accountability: debate teórico e o caso brasileiro. S. d. Disponível em: $<$ http://www.ufpa.br/epdir/images/docs/paper12.pdf>. Acesso em: 09 de maio de 2015>.

; SANO, Hironobu. Federalismo e articulação intergovernamental: os conselhos de secretários estaduais. In: HOCHMAN, Gilberto; FARIA, Carlos Aurélio Pimenta de (Orgs.). Federalismo e políticas públicas no Brasil. Rio de Janeiro: FIOCRUZ, 2013.

AGUILAR. Lei de Diretrizes Orçamentárias (LDO)/Lei orçamentária Anual (LOA). In: CASTRO, Carmem Lúcia Freitas de; AMABILE, Antônio Eduardo de Noronha; GONTIJO, Cynthia Rúbia Braga. Dicionário de Políticas Públicas. Barbacena, MG: EdUEMG, 2012.

ALBUQUERQUE, Claudiano Manuel; MEDEIROS, Márcio B.; FElJÓ, Paulo Henrique. Gestão de finanças públicas. 3. ed. Brasília, 2013. V. I. (Coleção Gestão Pública)

ANDRADA, Bonifácio J. T de Andrada. Federalismo. In: CASTRO, Carmem Lúcia Freitas de; AMABILE, Antônio Eduardo de Noronha; GONTIJO, Cynthia Rúbia Braga. Dicionário de Políticas Públicas. Barbacena, MG: EdUEMG, 2012.

ARRETCHE, Marta. Estado federativo e políticas sociais: determinantes da descentralização. Rio de Janeiro: Revan; São Paulo: FAPESP, 2000.

. Quando instituições federativas fortalecem o governo central? In: HOCHMAN, Gilberto; FARIA, Carlos Aurélio Pimenta de (Orgs.). Federalismo e políticas públicas no Brasil. Rio de Janeiro: FIOCRUZ, 2013. 
BAHL, Roy. Intergovernmental transfers in developing and transition countries: principles and practice. In: The World Bank, abr. 2000. Disponível em: <http://agris.fao.org/agris-search/search.do?recordID=US2012419717>. Acesso em: 16 abr. 2016.

. International Studies Program. School of Policy Studies. Implementation rules for fiscal decentralization. Georgia State University. Atlanta, 1999. Disponível em: $\quad<$ http://documents.worldbank.org/curated/en/236781468764725893/pdf/multipage.pdf $>$. Acesso em: 14 mar. 2016.

BAIÃO, Alexandre Lima. O papel das transferências intergovernamentais na equalização fiscal dos Municípios brasileiros. 2013. Dissertação (Mestrado em Administração) - Fundação Getúlio Vargas, Escola Brasileira de Administração Pública e de Empresas, Rio de Janeiro. Disponível em: $<$ http://bibliotecadigital.fgv.br/dspace/handle/10438/10988>. Acesso em: 02 mar. 2016.

BARRETO, Flavio Ataliba; MENDONÇA, Heloisa Helena; PINHO NETO, Valdemar de. Autonomia financeira, responsabilidade fiscal e seus efeitos sobre os indicadores sociais dos estados brasileiros. Cadernos de Finanças Públicas, Brasília, n. 10, p. 59-85, dez. 2010.

BATISTA, Karla da S. C. Município. In: CASTRO, Carmem Lúcia Freitas de; AMABILE, Antônio Eduardo de Noronha; GONTIJO, Cynthia Rúbia Braga. Dicionário de Políticas Públicas. Barbacena, MG: EdUEMG, 2012.

BLÖCHLIGER, H. E KING, DAVID. Fiscal autonomy of sub-central governments: an update. OECD Working Papers on Fiscal Federalism, n. 2, 2009. Disponível em: <https://www.oecd.org/tax/federalism/42982242.pdf>. Acesso em: 12 maio 2016.

BRANCO, Paulo Gustavo Gonet. Organização do Estado. In MENDES, Gilmar Ferreira; BRANCO, Paulo Gustavo Gonet. Curso de Direito Constitucional. 6. ed. São Paulo: Saraiva, 2011. 
BRASIL. Constituição (1988). Constituição da República Federativa do Brasil. Brasília: Senado Federal, 1988.

. Decreto n. 93.872, de 23 de dezembro de 1986. Dispõe sobre a unificação dos recursos de caixa do Tesouro Nacional, atualiza e consolida a legislação pertinente e dá outras providências. Brasília, 1986. Disponível em <http://www.planalto.gov.br/ccivil_03/decreto/d93872.htm>. Acesso em: 13 abr. 2016.

. Lei Complementar n. 101, de 04 de maio de 2000. Estabelece normas de finanças públicas voltadas para a responsabilidade na gestão fiscal e dá outras providências. Brasília, 2000. Disponível em <https://www.planalto.gov.br/ccivil_03/LEIS/LCP/Lcp101.htm>. Acesso em: 13 abr. 2016.

. Lei n. 4.320, de 17 de março de 1964 . Estatui normas gerais de direito financeiro para elaboração e controle dos orçamentos e balanços da União, dos Estados, dos Municípios e do Distrito Federal. Brasília, 1964. Disponível em <https://www.planalto.gov.br/ccivil_03/Leis/L4320.htm>. Acesso em: 13 abr. 2016.

. Mensagem Presidencial: Plano Plurianual 2016-2016 (Desenvolvimento, Produtividade e Inclusão Social). Disponível em:

$<$ http://www.planejamento.gov.br/secretarias/upload/arquivo/spi-1/ppa-2016 2019/ppa-2016-2019-ascom-3.pdf>. Acesso em: 16 jun. 2016.

. Ministério do Planejamento, Orçamento e Gestão. Ministério da Fazenda. Controladoria-Geral da União. Gabinete da Ministra. Portaria Interministerial CGU/MF/MP n. 507, de 24 de novembro de 2011. Brasília, 2011. Disponível em: $<$ https://www.ufmg.br/proplan/wp-content/uploads/Portaria-Interministerialn\%C2\%BA-507-atualizado-dia-23-05-2016.pdf>. Acesso em: 13 abr 2016. 
- Ministério do Planejamento, Orçamento e Gestão. Secretaria de Logística e Tecnologia da Informação. Sistema de Gestão de Convênios e Contratos de Repasse (Siconv). Um novo paradigma nas Transferências Voluntárias da União. $\quad$ S. $\quad$ d. $\quad$ Disponível em: <http://repositorio.enap.gov.br/bitstream/handle/1/254/Sistema\%20de\%20Gest\%C3 \%A30\%20de\%20Conv\%C3\%AAnios\%20e\%20Contratos\%20de\%20Repasse\%20\%2 8Siconv\%29.pdf?sequence=1 >. Acesso em: 14 abr. 2016.

. Ministério do Planejamento, Orçamento e Gestão. Secretaria de Orçamento Federal. Manual Técnico de Orçamento - Versão 2016. Brasília, 2016.

. Transferência Voluntária. In: Portal da Transparência, 2016. Disponível em: <http://www.portaldatransparencia.gov.br/glossario/DetalheGlossario.asp?letra=t>. Acesso em: 02 mar. 2016.

BRYNER, Gary C. Organizações públicas e políticas públicas. In: PETERS, Guy; PIERRE, Jon (Orgs.). Administração Pública: coletânea. Trad. de Sonia Midiori Yamamoto e Mirian Oliveira. São Paulo: Editora UNESP; Brasília: ENAP, 2010.

CARDOZO, Soraia Aparecida. Sistema federativo brasileiro e limites ao desenvolvimento local e descentralizado. In: XII Encontro Nacional de Economia Política, 2007. Disponível em: <http://www.sep.org.br/artigos/download?id=1270\&title=Sistema\%20Federativo\%20 Brasileiro\%20e\%20Limites\%20ao\%20Desenvolvimento\%20Local\%20e\%20Descentr alizado>. Acesso em: 10 maio 2016.

CARNEIRO, Ricardo. Descentralização e financiamento dos Municípios no Brasil contemporâneo. R. Adm. FACES Journal, Belo Horizonte, v. 9, n. 2, p. 87-104, abr./jun. 2010.2 Disponível em: <http://www.fumec.br/revistas/facesp/article/viewFile/183/180>. Acesso em: 27 mar. 2016. 
CASTRO. Carmem Lucia Freitas de. Plano Plurianual. In: CASTRO, Carmem Lúcia Freitas de; AMABILE, Antônio Eduardo de Noronha; GONTIJO, Cynthia Rúbia Braga. Dicionário de Políticas Públicas. Barbacena, MG: EdUEMG, 2012.

CHRISTIAN, Laville. A construção do saber: manual de metodologia de pesquisa em ciências humanas. Porto Alegre: Artmed; Belo Horizonte: Editora UFMG, 1999.

CUNHA, Rosani Evangelista da. Federalismo e relações intergovernamentais: os consórcios públicos como instrumento de cooperação federativa. RSP - Revista do Serviço Público, a. 55, n. 3, jul./set. 2004. Disponível em: <http://oaji.net/articles/2015/1978-1432646915.pdf>. Acesso em: 27 mar. 2016.

CULAU, Ariosto Antunes; FORTIS, Martin Francisco de Almeida. Transparência e controle social na administração pública brasileira: avaliação das principais inovações introduzidas pela Lei de Responsabilidade Fiscal. In: Congreso Internacional del Clad sobre la Reforma del Estado y de la Administración Pública, 11, Ciudad de Guatemala, 2006. Disponível em: <https://bvc.cgu.gov.br/bitstream/123456789/3235/1/transparencia_controle_social_a dministracao.pdf>. Acesso em: 05 maio 2016.

ESPINOSA, Roberto Moreno. Descentralização. In: CASTRO, Carmem Lúcia Freitas de; AMABILE, Antônio Eduardo de Noronha; GONTIJO, Cynthia Rúbia Braga. Dicionário de Políticas Públicas. Barbacena, MG: EdUEMG, 2012.

FERREIRA, Dimas Enéas Soares. Experiências recentes de controle social sobre o processo de orçamentação pública municipal no Brasil. 2006 Monografia (XI Prêmio Tesouro Nacional) - Secretaria do Tesouro Nacional, Escola De Administração Fazendária, Brasília. Disponível em: <http://www3.tesouro.fazenda.gov.br/Premio_TN/XIpremio/sistemas/2tosiXIPTN/2pre mio_tosi.pdf $>$. Acesso em: 10 maio 2016.

FILELLINI, Alfredo. Economia do Setor público. São Paulo: Atlas, 1989. 
GIACOMONI, James. Orçamento público. 14. ed. ampl., rev. e atual. 2. reimpr. São Paulo: Atlas, 2008.

GARSON, Sol Braule Pinto. Orçamento público. In: GIAMBIAGI, Fábio; ALÉM, Ana. Finanças públicas: teoria e prática no Brasil. 5. ed. rev. e atual. Rio de Janeiro: Elsevier, 2016.

GOMIDE, Alexandre de Ávila; PIRES, Roberto Rocha C. (Eds.). Capacidades estatais e democracia: a abordagem dos arranjos institucionais para análise de políticas públicas. Brasília: IPEA, 2014.

HARADA, Kiyoshi. Direito Financeiro e Tributário. 16 ed. São Paulo: Atlas, 2007.

HERMANN, Jennifer. Auge e declínio do modelo de crescimento com endividamento: o II PND e a crise da dívida externa (1974 - 1984). In: GIAMBIAGI, Fábio; VILLELA, André; CASTRO, Lavínia Barros de; HERMANN, Jennifer. (Orgs.). Economia brasileira contemporânea: 1945-2010. 2. ed. Rio de Janeiro: Elservier, 2011.

LOPES, Cristiano Aguiar. Os impactos da transparência na efetividade dos gastos públicos e na consolidação da democracia. In: XXXII Congresso Brasileiro de Ciência da Comunicação, Curitiba, 2009. Disponível em: <http://www.intercom.org.br/papers/nacionais/2009/resumos/R4-2191-1.pdf>. Acesso em: 10 maio 2016.

KERBAUY, Maria Teresa Miceli. Federalismo, descentralização e democracia. Estudos de Sociologia, 2007.

MACHADO JUNIOR, José Teixeira; REIS, Heraldo da Costa. A Lei n. 4.320 comentada. 35. ed. rev. atual. Rio de Janeiro: IBAM, 2015.

MALMEGRIN, Maria Leonilda. Redes públicas de cooperação local. Florianópolis: Departamento de Ciências da Administração/UFSC; Brasília: CAPES, UAB, 2010. 
MARTINEZ-VAZQUEZ, Jorge; SEPULVEDA, Cristian F. Intergovernmental transfers in Latin America: a policy reform perspective. In: International Center for Public Policy Working Paper Series, Paper 88, 2011. Disponível em: <http://scholarworks.gsu.edu/icepp/88/>. Acesso em: 12 abr. 2016.

MATIAS-PEREIRA, José. Curso de Administração Pública: foco nas instituições e ações governamentais. São Paulo: Atlas, 2008.

. Finanças públicas: a política orçamentária no Brasil. 3 ed. São Paulo: Atlas, 2006.

Manual de gestão pública contemporânea. 2 ed. São Paulo: Atlas, 2009.

MOUTINHO, José da Assunção; KNIESS, Claudia Terezinha. Transferências voluntárias como ferramentas para descentralização de políticas públicas: identificação de correlação entre variáveis. In: Anais do IV SINGEP e III S2IS, São Paulo, 08, 09 e 10 de novembro de 2015. Disponível em: <http://www.singep.org.br/4singep/resultado/59.pdf>. Acesso em: 06 maio 2016.

NEVES, Fernanda Siqueira. Gestão. In: CASTRO, Carmem Lúcia Freitas de; AMABILE, Antônio Eduardo de Noronha; GONTIJO, Cynthia Rúbia Braga. Dicionário de Políticas Públicas. Barbacena, MG: EdUEMG, 2012.

PALTT NETO, Orion Augusto; CRUZ, Flávio da; ENSSLIN, Sandra Rolim; ENSSLIN, Leonardo. Publicidade e transparência nas contas públicas: obrigatoriedade e abrangência desses princípios na administração pública brasileira. Contab. Vista \& Rev., v. 18, n. 1, p. 75-94, jan./mar. 2007. Disponível em: <http://revistas.face.ufmg.br/index.php/contabilidadevistaerevista/article/view/320/31 3>. Acesso em: 10 maio 2016. 
OLIVEIRA, Gilmar Castelo Branco de. A importância do controle interno nas finanças públicas. 2013. Dissertação (Mestrado Profissional em Gestão de Finanças Públicas) - Universidade de Brasília, Faculdade de Economia, Administração e Contabilidade, Programa de Pós-Graduação em Economia, Brasília. Disponível em: <http://repositorio.unb.br/bitstream/10482/14036/1/2013_GilmarCasteloBrancodeOliv eira.pdf>. Acesso em: 05 maio 2016.

PEREIRA JUNIOR, Jesse Torres; DOTTI, Martines Restelatto. Convênios e outros instrumentos de "administração consensual" na gestão pública do século XXI: restrições em ano eleitoral. 2 ed. rev., atul. e ampl. Belo Horizonte: Fórum., 2013.

PRZEWORSKI, Adam. Sobre o desenho do Estado: uma perspectiva agente $x$ principal. In: BRESSER-PEREIRA, Luiz Carlos; SPINK, Peter Kevin. (Orgs.). Reforma do Estado e Administração Pública gerencial. Trad. de Carolina Andrade. 7. ed. Rio de janeiro: Editora FGV, 2006.

RADIN, Beryl A. Os instrumentos da gestão intergovernamental. In: PETERS, Guy; PIERRE, Jon (Orgs.). Administração Pública: coletânea. Trad. de Sonia Midiori Yamamoto e Mirian Oliveira. São Paulo: Editora UNESP; Brasília: ENAP, 2010.

RAUSCH, Rita Buzzi; SOARES, Maurélio. Controle social na Administração Pública: a importância da transparência das contas públicas para inibir a corrupção. REPeC Revista de Educação e Pesquisa em Contabilidade, Brasília, v. 4, n. 3, p. 23-43, set./dez. $2010 . \quad$ Disponível em: <http://www.repec.org.br/index.php/repec/article/view/250/85>. Acesso em: 05 maio 2016.

REZENDE, Fernando Antônio. Finanças públicas. 2. ed. 7. reimpr. São Paulo: Atlas, 2011. 
ROCHA, Bruno Fabrício Ferreira da. Governança em múltiplos níveis: análise do modelo de política fiscal brasileiro. 2015. Dissertação (Mestrado em Administração) - Universidade de Brasília, Faculdade de Economia, Administração e Contabilidade, Programa de Pós-Graduação em Administração, Brasília. Disponível em: <http://repositorio.unb.br/bitstream/10482/19755/1/2015_BrunoFabr\%C3\%ADcioFerr eiradaRocha.pdf>. Acesso em: 10 maio 2016.

ROSEN, Harvey S.; GAYER, Ted. Finanças públicas. 10. ed. Porto Alegre: AMGH, 2015.

SCHWARTZMAN, Simon (Org.). A via democrática: como o desenvolvimento econômico e social ocorre no Brasil. 1. ed. Rio de Janeiro: Elservier, 2014.

SILVA, Moacir Marques. Curso de auditoria governamental: de acordo com as Normas Internacionais de Auditoria Pública aprovadas pela INTOSAI. São Paulo: Atlas, 2009.

SOUZA, Celina. Intermediação de Interesses Regionais no Brasil: o impacto do federalismo e da descentralização. Dados, Rio de Janeiro, v. 41, n. 3, 1998. Disponível em: <http://dx.doi.org/10.1590/S0011-52581998000300003>. Acesso em 10 maio 2016.

. Governos locais e gestão de Políticas Públicas universais. São Paulo em Perspectiva, v. $18, \quad$ n. 2 , p. 27-41, 2004. Disponível em: <http://www.scielo.br/pdf/spp/v18n2/a04v18n2.pdf>. Acesso em: 26 mar. 2016.

. Políticas Públicas: uma revisão da literatura. Sociologias, Porto Alegre, a. 8, n. 16, p. 20-45, jul./dez. 2006. Disponível em: <http://www.scielo.br/pdf/soc/n16/a03n16.pdf>. Acesso em: 26 mar. 2016>.

TOLEDO, Geraldo Luciano; OVALLE, Ivo Izidoro. Estatística básica. 2 ed. São Paulo: Atlas, 1985. 
TORRES, Marcelo Douglas de Figueiredo. Estado, democracia e Administração Pública no Brasil. Rio de Janeiro: Editora FGV, 2004.

XUN, Wu. Guia de Políticas Públicas: gerenciando processos. Trad. de Ricardo Avelar de Souza. Brasília: ENAP, 2014. 


\section{APÊNDICES}




\section{APÊNDICE "A" - TABELA INDICANDO VALOR DE REPASSE POR NATUREZA JURÍDICA}

Tabela A - Valor de repasse por natureza jurídica - período 2008-2015.

\begin{tabular}{|c|c|c|c|c|c|c|c|c|c|c|c|c|}
\hline \multirow{2}{*}{$\begin{array}{c}\text { NATUREZA } \\
\text { ANO }\end{array}$} & \multicolumn{2}{|c|}{$\begin{array}{c}\text { Administração Pública } \\
\text { Estadual ou do Distrito } \\
\text { Federal }\end{array}$} & \multicolumn{2}{|c|}{$\begin{array}{l}\text { Administração Pública } \\
\text { Municipal }\end{array}$} & \multicolumn{2}{|c|}{ Consórcio Público } & \multicolumn{2}{|c|}{$\begin{array}{c}\text { Empresa } \\
\text { pública/Sociedade de } \\
\text { economia mista }\end{array}$} & \multicolumn{2}{|c|}{$\begin{array}{l}\text { Organização da } \\
\text { Sociedade Civil }\end{array}$} & \multirow[t]{2}{*}{ Total } & \multirow[t]{2}{*}{$\%$} \\
\hline & Valor & $\%$ & Valor & $\%$ & Valor & $\%$ & Valor & $\%$ & Valor & $\%$ & & \\
\hline 2008 & 1.181 .110 .000 & $48 \%$ & 463.308 .871 & $19,02 \%$ & 783.222 & $0,03 \%$ & 95.865 .613 & $3,94 \%$ & 694.561 .442 & $28,52 \%$ & 2.435.629.148 & $100 \%$ \\
\hline 2009 & 3.097.243.242 & $27,86 \%$ & 5.924 .204 .501 & $53,30 \%$ & 27.513 .727 & $0,25 \%$ & 366.198 .856 & $3,29 \%$ & 1.700 .453 .467 & $15,30 \%$ & 11.115.613.793 & $100 \%$ \\
\hline 2010 & 2.106 .837 .461 & $19,99 \%$ & 6.007 .857 .459 & $56,99 \%$ & 73.919 .617 & $0,70 \%$ & 201.076 .291 & $1,91 \%$ & 2.151.869.731 & $20,41 \%$ & 10.541 .560 .558 & $100 \%$ \\
\hline 2011 & 3.211 .043 .442 & $34,49 \%$ & 3.708 .132 .490 & $39,83 \%$ & 168.841 .120 & $1,81 \%$ & 140.405 .256 & $1,51 \%$ & 2.080.999.134 & $22,35 \%$ & 9.309 .421 .443 & $100 \%$ \\
\hline 2012 & 5.611 .808 .292 & $49,62 \%$ & 3.458 .985 .200 & $30,58 \%$ & 11.576 .273 & $0,10 \%$ & 227.160 .678 & $2,01 \%$ & 2.000.728.469 & $17,69 \%$ & 11.310 .258 .912 & $100 \%$ \\
\hline 2013 & 4.534 .512 .126 & $29,90 \%$ & 6.637.573.386 & $43,77 \%$ & 190.294 .881 & $1,25 \%$ & 427.602 .571 & $2,82 \%$ & 3.374.399.631 & $22,25 \%$ & 15.164.382.594 & $100 \%$ \\
\hline 2014 & 1.000 .807 .079 & $15,78 \%$ & 3.734 .809 .250 & $58,88 \%$ & 100.428 .746 & $1,58 \%$ & 26.791 .315 & $0,42 \%$ & 1.480 .273 .686 & $23,34 \%$ & 6.343.110.076 & $100 \%$ \\
\hline 2015 & 1.192 .326 .301 & $21,93 \%$ & 3.053.231.466 & $56,17 \%$ & 9.299 .918 & $0,17 \%$ & 24.328 .744 & $0,45 \%$ & 1.156.979.417 & $21,28 \%$ & 5.436 .165 .846 & $100 \%$ \\
\hline Total & 21.935 .687 .943 & $30,60 \%$ & 33.041 .971 .322 & $46,07 \%$ & 583.007 .505 & $0,81 \%$ & 1.509 .429 .324 & $2,11 \%$ & 14.640 .264 .977 & $20,42 \%$ & 71.728.844.196 & $100 \%$ \\
\hline
\end{tabular}

Fonte: Adaptado de Siconv (2016). 


\section{APÊNDICE "B" - TABELA INDICANDO AS TRANSFERÊNCIAS VOLUNTÁRIAS DA UNIÃO POR FAIXA DE VALOR}

Tabela B - Transferências voluntárias da união por faixa de valor - período 2008-2015 (continua).

\begin{tabular}{|c|c|c|}
\hline Ano & Faixa de Valores & Quantidade \\
\hline \multirow{6}{*}{2008} & até $100 \mathrm{mil}$ & 115 \\
\hline & entre $100-250 \mathrm{mil}$ & 977 \\
\hline & entre 250 - 500 mil & 488 \\
\hline & entre $500-750 \mathrm{mil}$ & 173 \\
\hline & entre 750 mil - 1,5 milhão & 211 \\
\hline & mais de 1,5 milhão & 326 \\
\hline \multirow{6}{*}{2009} & até $100 \mathrm{mil}$ & 1.014 \\
\hline & entre $100-250 \mathrm{mil}$ & 10.914 \\
\hline & entre 250 - 500 mil & 4.665 \\
\hline & entre $500-750 \mathrm{mil}$ & 1.589 \\
\hline & entre 750 mil - 1,5 milhão & 1.325 \\
\hline & mais de 1,5 milhão & 1.180 \\
\hline \multirow{6}{*}{2010} & até 100 mil & 1.131 \\
\hline & entre $100-250 \mathrm{mil}$ & 10.331 \\
\hline & entre 250 - 500 mil & 4.234 \\
\hline & entre 500 - 750 mil & 1.561 \\
\hline & entre 750 mil - 1,5 milhão & 1.426 \\
\hline & mais de 1,5 milhão & 1.170 \\
\hline \multirow{6}{*}{2011} & até $100 \mathrm{mil}$ & 513 \\
\hline & entre $100-250 \mathrm{mil}$ & 4.996 \\
\hline & entre 250 - 500 mil & 2.871 \\
\hline & entre $500-750 \mathrm{mil}$ & 1.114 \\
\hline & entre 750 mil - 1,5 milhão & 955 \\
\hline & mais de 1,5 milhão & 948 \\
\hline \multirow{6}{*}{2012} & até $100 \mathrm{mil}$ & 267 \\
\hline & entre $100-250 \mathrm{mil}$ & 2.332 \\
\hline & entre $250-500 \mathrm{mil}$ & 3.696 \\
\hline & entre $500-750$ mil & 1.215 \\
\hline & entre 750 mil - 1,5 milhão & 1.051 \\
\hline & mais de 1,5 milhão & 1.202 \\
\hline
\end{tabular}


Tabela B - Transferências voluntárias da união por faixa de valor - período 2008-2015 (conclusão).

\begin{tabular}{|c|c|c|}
\hline Ano & Faixa de Valores & Quantidade \\
\hline \multirow{6}{*}{2013} & até $100 \mathrm{mil}$ & 292 \\
\hline & entre $100-250 \mathrm{mil}$ & 3.494 \\
\hline & entre 250 - 500 mil & 6.249 \\
\hline & entre 500 - 750 mil & 1.977 \\
\hline & entre 750 mil - 1,5 milhão & 1.459 \\
\hline & mais de 1,5 milhão & 1.265 \\
\hline \multirow{6}{*}{2014} & até $100 \mathrm{mil}$ & 391 \\
\hline & entre $100-250$ mil & 3.067 \\
\hline & entre 250 - 500 mil & 4.708 \\
\hline & entre 500 - 750 mil & 1.164 \\
\hline & entre 750 mil - 1,5 milhão & 1.023 \\
\hline & mais de 1,5 milhão & 620 \\
\hline \multirow{6}{*}{2015} & até $100 \mathrm{mil}$ & 253 \\
\hline & entre $100-250 \mathrm{mil}$ & 2.128 \\
\hline & entre 250 - 500 mil & 3.036 \\
\hline & entre $500-750$ mil & 734 \\
\hline & entre 750 mil - 1,5 milhão & 877 \\
\hline & mais de 1,5 milhão & 584 \\
\hline Total & & 97.311 \\
\hline
\end{tabular}

Fonte: Adaptado de Siconv (2016). 


\section{APÊNDICE “C” - TABELAS INDICANDO O TEMPO DE VIGÊNCIA DOS ACORDOS EM EXECUÇÃO}

Tabela C - Tempo médio de vigência dos acordos em execução - todos os partícipes - período 2008-2015 - em R \$.

\begin{tabular}{|c|c|c|c|c|c|c|c|c|}
\hline Ano & $\begin{array}{l}\text { Quantidade } \\
\text { de Acordos }\end{array}$ & $\begin{array}{l}\text { Média de } \\
\text { tempo de } \\
\text { vigência }\end{array}$ & $\begin{array}{l}\text { DesvPad } \\
\text { de tempo } \\
\text { de } \\
\text { vigência }\end{array}$ & \multicolumn{5}{|c|}{ Valor } \\
\hline 2009 & 2.142 & 6,61 & 0,41 & $2.010 .920 .825,59$ & $332.439 .605,28$ & $2.343 .360 .430,87$ & 1.492.327.165,81 & $851.033 .265,06$ \\
\hline 2010 & 2.516 & 5,77 & 0,42 & 2.833.462.354,79 & $394.703 .339,08$ & $3.228 .165 .693,87$ & $2.020 .342 .888,41$ & $1.207 .822 .805,46$ \\
\hline 2013 & 10.366 & 2,84 & 0,59 & $13.853 .574 .782,44$ & 2.867.011.372,95 & $16.720 .586 .155,39$ & 7.122.527.229,31 & $9.598 .058 .926,08$ \\
\hline 2014 & 10.106 & 2,22 & 0,65 & $6.118 .687 .709,73$ & $319.359 .404,00$ & $6.438 .047 .113,73$ & 2.159.995.796,97 & $4.278 .051 .316,76$ \\
\hline 2015 & 7.735 & 2,00 & 0,92 & $5.320 .001 .403,77$ & $198.062 .381,51$ & $5.520 .776 .822,56$ & $431.349 .996,94$ & $5.089 .426 .825,62$ \\
\hline $\begin{array}{l}\text { Total } \\
\text { Geral }\end{array}$ & 39.827 & 3,13 & 1,49 & $41.449 .411 .608,36$ & $5.744 .235 .071,15$ & 47.205.383.554,29 & 19.964.264.865,54 & 27.241.118.688,75 \\
\hline
\end{tabular}

Fonte: Adaptado de Siconv (2016). 
Tabela D - Tempo médio de vigência dos acordos em execução - Consórcio Público - período 2008-2015 - em R\$.

\begin{tabular}{|c|c|c|c|c|c|c|c|c|}
\hline Ano & $\begin{array}{l}\text { Quantidade } \\
\text { de Acordos }\end{array}$ & $\begin{array}{l}\text { Média de } \\
\text { tempo de } \\
\text { vigência }\end{array}$ & $\begin{array}{l}\text { DesvPad } \\
\text { de tempo } \\
\text { de } \\
\text { vigência }\end{array}$ & \multicolumn{5}{|c|}{ Valor } \\
\hline 2009 & 1 & 7,00 & 0,19 & $18.999 .949,20$ & $590.050,80$ & $19.590 .000,00$ & $13.300 .000,00$ & $6.290 .000,00$ \\
\hline 2010 & 13 & 5,88 & 0,22 & $29.608 .326,35$ & $3.533 .472,51$ & $33.141 .798,86$ & $19.501 .442,15$ & $13.640 .356,71$ \\
\hline 2013 & 18 & 2,89 & 0,50 & $177.713 .025,94$ & $2.124 .235,68$ & $179.837 .261,62$ & $90.399 .222,10$ & $89.438 .039,52$ \\
\hline 2014 & 26 & 1,88 & 0,15 & $96.761 .894,05$ & $760.170,80$ & $97.522 .064,85$ & $42.608 .430,97$ & $54.913 .633,88$ \\
\hline 2015 & 25 & 1,85 & 0,60 & $10.808 .833,30$ & $425.676,56$ & $11.234 .509,86$ & 0,00 & $11.234 .509,86$ \\
\hline $\begin{array}{l}\text { Total } \\
\text { Geral }\end{array}$ & 111 & 3,23 & 2,24 & $455.122 .992,45$ & $10.343 .341,22$ & $465.466 .333,67$ & $239.884 .506,20$ & $225.581 .827,47$ \\
\hline
\end{tabular}

Fonte: Adaptado de Siconv (2016). 
Tabela E - Tempo médio de vigência dos acordos em execução - Empresa Pública e Sociedade de Economia Mista - período 2008-2015 - em R\$.

\begin{tabular}{|c|c|c|c|c|c|c|c|c|}
\hline Ano & $\begin{array}{l}\text { Quantidade } \\
\text { de Acordos }\end{array}$ & $\begin{array}{l}\text { Média de } \\
\text { tempo de } \\
\text { vigência }\end{array}$ & $\begin{array}{c}\text { DesvPad } \\
\text { de tempo } \\
\text { de } \\
\text { vigência }\end{array}$ & \multicolumn{5}{|c|}{ Valor } \\
\hline 2009 & 8 & 6,65 & 0,74 & $38.681 .037,82$ & $6.853 .868,76$ & $45.534 .906,58$ & $42.641 .037,82$ & $2.893 .868,76$ \\
\hline 2010 & 12 & 6,25 & 0,36 & $55.607 .105,43$ & $11.363 .019,02$ & $66.970 .124,45$ & $40.841 .538,36$ & $26.128 .586,09$ \\
\hline 2013 & 68 & 2,72 & 0,57 & $395.490 .537,68$ & $18.311 .284,58$ & $413.801 .822,26$ & $343.377 .591,70$ & $70.424 .230,56$ \\
\hline 2014 & 34 & 2,10 & 0,42 & $23.889 .928,03$ & $1.915 .877,09$ & $25.805 .805,12$ & $14.259 .484,72$ & $11.546 .320,40$ \\
\hline 2015 & 35 & 1,93 & 0,73 & $25.436 .751,89$ & $1.928 .708,26$ & $27.365 .460,15$ & $1.017 .534,00$ & $26.347 .926,15$ \\
\hline $\begin{array}{l}\text { Total } \\
\text { Geral }\end{array}$ & 220 & 3,18 & 1,44 & $739.089 .148,05$ & $80.991 .053,37$ & $820.080 .201,42$ & $578.228 .225,27$ & $241.851 .976,15$ \\
\hline
\end{tabular}

Fonte: Adaptado de Siconv (2016). 
Tabela F - Tempo médio de vigência dos acordos em execução - Administração Pública Estadual - período 2008-2015 - em R \$.

\begin{tabular}{|c|c|c|c|c|c|c|c|c|}
\hline Ano & $\begin{array}{l}\text { Quantidade } \\
\text { de Acordos }\end{array}$ & $\begin{array}{l}\text { Média de } \\
\text { tempo de } \\
\text { vigência }\end{array}$ & $\begin{array}{c}\text { DesvPad } \\
\text { de tempo } \\
\text { de } \\
\text { vigência }\end{array}$ & \multicolumn{5}{|c|}{ Valor } \\
\hline 2009 & 166 & 6,69 & 0,57 & $508.484 .296,68$ & $133.061 .574,49$ & $641.545 .871,17$ & $456.242 .071,48$ & $185.303 .799,69$ \\
\hline 2010 & 181 & 5,98 & 0,66 & $846.125 .222,52$ & $167.553 .064,96$ & $1.013 .678 .287,48$ & $736.139 .629,06$ & $277.538 .658,42$ \\
\hline 2013 & 1.048 & 2,91 & 0,83 & $5.071 .299 .552,41$ & $2.297 .684 .323,42$ & 7.368.983.875,83 & $2.334 .409 .919,71$ & $5.034 .573 .956,12$ \\
\hline 2014 & 800 & 2,06 & 0,57 & $1.008 .262 .593,30$ & $72.288 .563,63$ & $1.080 .551 .156,93$ & $267.514 .141,32$ & $813.037 .015,61$ \\
\hline 2015 & 758 & 1,85 & 0,92 & $1.177 .587 .518,04$ & $77.647 .856,96$ & $1.255 .235 .375,00$ & $125.486 .229,02$ & $1.129 .749 .145,98$ \\
\hline $\begin{array}{l}\text { Total } \\
\text { Geral }\end{array}$ & 4.350 & 3,27 & 1,54 & $14.689 .071 .843,08$ & $3.859 .785 .523,84$ & $18.549 .910 .361,56$ & 7.373.279.761,44 & $11.176 .630 .600,12$ \\
\hline
\end{tabular}

Fonte: Adaptado de Siconv (2016). 
Tabela G - Tempo médio de vigência dos acordos em execução - Administração Pública Municipal - período 2008-2015 - em R\$.

\begin{tabular}{|c|c|c|c|c|c|c|c|c|}
\hline Ano & $\begin{array}{l}\text { Quantidade } \\
\text { de Acordos }\end{array}$ & $\begin{array}{l}\text { Média de } \\
\text { tempo de } \\
\text { vigência }\end{array}$ & $\begin{array}{c}\text { DesvPad } \\
\text { de tempo } \\
\text { de } \\
\text { vigência }\end{array}$ & \multicolumn{5}{|c|}{ Valor } \\
\hline 2009 & 1.828 & 6,58 & 0,38 & $1.261 .511 .474,99$ & $182.980 .409,55$ & $1.444 .491 .884,54$ & $826.699 .934,43$ & $617.791 .950,11$ \\
\hline 2010 & 2.060 & 5,74 & 0,37 & 1.521.466.244,95 & $187.567 .053,84$ & $1.709 .033 .298,79$ & $904.301 .848,94$ & $804.731 .449,85$ \\
\hline 2013 & 8.722 & 2,83 & 0,54 & $5.367 .486 .056,85$ & $528.400 .569,12$ & $5.895 .886 .625,97$ & $1.995 .373 .000,05$ & $3.900 .513 .625,92$ \\
\hline 2014 & 7.341 & 2,30 & 0,68 & $3.458 .219 .767,44$ & $218.347 .429,98$ & $3.676 .567 .197,42$ & $847.723 .277,55$ & 2.828.843.919,87 \\
\hline 2015 & 5.534 & 2,20 & 0,88 & $2.961 .730 .051,66$ & $110.704 .455,82$ & $3.075 .147 .544,76$ & $76.916 .557,68$ & 2.998.230.987,08 \\
\hline $\begin{array}{l}\text { Total } \\
\text { Geral }\end{array}$ & 30.375 & 3,21 & 1,45 & $18.184 .505 .508,47$ & $1.679 .759 .462,20$ & $19.868 .781 .757,95$ & $6.618 .531 .129,29$ & $13.250 .250 .628,66$ \\
\hline
\end{tabular}

Fonte: Adaptado de Siconv (2016). 
Tabela H - Tempo médio de vigência dos acordos em execução - Entidade Privada sem fins lucrativos - período 2008-2015 - em R \$.

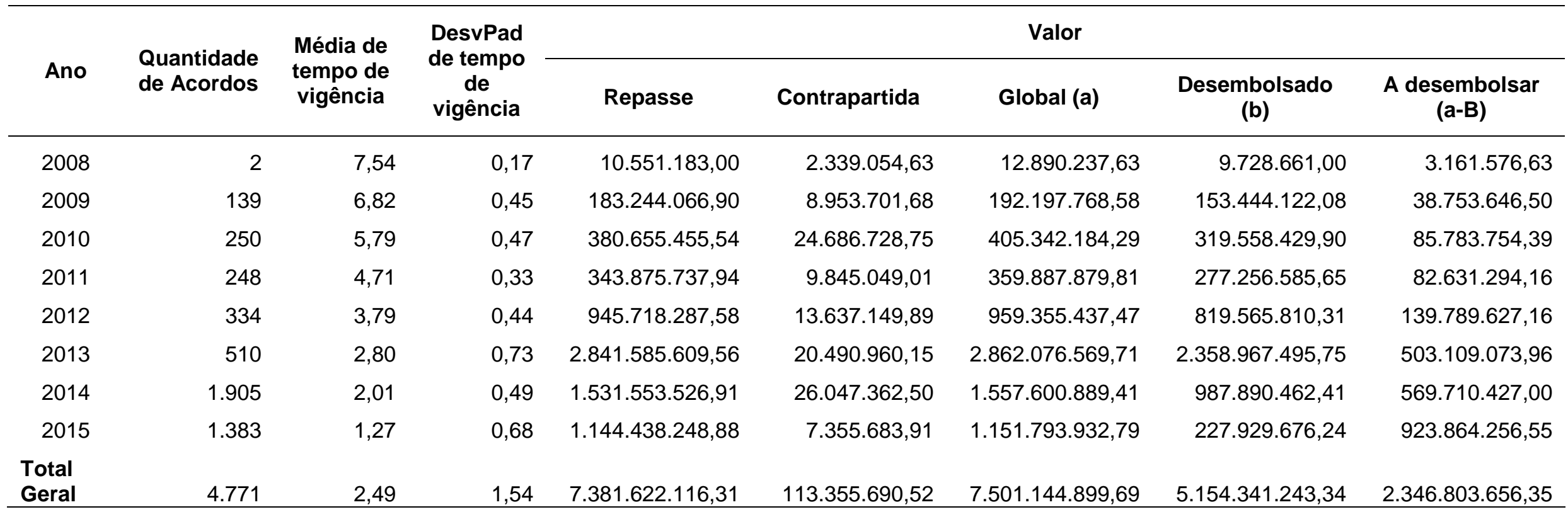

Fonte: Adaptado de Siconv (2016). 
APÊNDICE “D”- TABELAS INDICANDO ACORDOS COM PRESTAÇÕES DE CONTAS SEM RECURSOS EXECUTADOS

Tabela I - Prestação de contas sem desembolso - Consórcios públicos - Período de observação 2008 - 2015 - em R\$.

\begin{tabular}{|c|c|c|c|c|c|}
\hline \multirow[b]{2}{*}{ Ano } & \multirow[b]{2}{*}{ Quantidade de acordos } & \multirow{2}{*}{$\begin{array}{l}\text { Média de Tempo de } \\
\text { vigência }\end{array}$} & \multicolumn{3}{|c|}{ Valor } \\
\hline & & & Repasse & Contrapartida & Global \\
\hline 2010 & 1 & 3,00 & $1.396 .000,00$ & $381.000,00$ & $1.777 .000,00$ \\
\hline 2011 & 1 & 2,17 & $318.600,00$ & $8.640,00$ & $327.240,00$ \\
\hline 2013 & 1 & 2,00 & 3.144.341,76 & $64.170,24$ & $3.208 .512,00$ \\
\hline 2014 & 1 & 1,00 & $1.613 .628,72$ & $16.299,28$ & $1.629 .928,00$ \\
\hline Total Geral & 4 & 2,04 & $6.472 .570,48$ & $470.109,52$ & $6.942 .680,00$ \\
\hline
\end{tabular}

Fonte: Adaptado de Siconv (2016). 
Tabela J- Prestação de contas sem desembolso - Empresas Públicas dos diversos entes - Período de observação 2008-2015 - em R\$.

\begin{tabular}{|c|c|c|c|c|c|}
\hline \multirow[b]{2}{*}{ Ano } & \multirow[b]{2}{*}{ Quantidade de acordos } & \multirow{2}{*}{$\begin{array}{l}\text { Média de Tempo de } \\
\text { vigência }\end{array}$} & \multicolumn{3}{|c|}{ Valor } \\
\hline & & & Repasse & Contrapartida & Global \\
\hline 2008 & 7 & 1,7 & $8.424 .859,00$ & $4.216 .736,99$ & $12.641 .595,99$ \\
\hline 2009 & 2 & 3,0 & $3.593 .559,77$ & $453.000,00$ & $4.046 .559,77$ \\
\hline 2010 & 5 & 2,2 & $3.884 .221,86$ & $469.954,27$ & $4.354 .176,13$ \\
\hline 2011 & 1 & 1,4 & $300.000,00$ & $33.400,00$ & $333.400,00$ \\
\hline 2012 & 3 & 2,5 & $1.160 .372,98$ & $104.046,73$ & $1.264 .419,71$ \\
\hline 2013 & 1 & 1,9 & $749.700,00$ & 0,00 & $749.700,00$ \\
\hline Total Geral & 19 & 2,1 & $18.112 .713,61$ & $5.277 .137,99$ & $23.389 .851,60$ \\
\hline
\end{tabular}

Fonte: Adaptado de Siconv (2016). 
Tabela K - Prestação de contas sem desembolso - administrações públicas diretas estaduais e do DF - Período de observação 2008-2015 - em R\$.

\begin{tabular}{|c|c|c|c|c|c|}
\hline \multirow[b]{2}{*}{ Ano } & \multirow[b]{2}{*}{ Quantidade de acordos } & \multirow{2}{*}{$\begin{array}{l}\text { Média de Tempo de } \\
\text { vigência }\end{array}$} & \multicolumn{3}{|c|}{ Valor } \\
\hline & & & Repasse & Contrapartida & Global \\
\hline 2008 & 87 & 1,6 & $130.025 .822,74$ & $20.360 .893,90$ & $150.386 .716,64$ \\
\hline 2009 & 75 & 2,0 & $130.299 .678,66$ & $28.848 .470,87$ & $159.148 .149,53$ \\
\hline 2010 & 36 & 2,3 & $40.172 .771,59$ & $35.438 .668,63$ & $75.611 .440,22$ \\
\hline 2011 & 34 & 2,9 & $66.764 .322,19$ & $18.238 .135,00$ & $85.002 .457,19$ \\
\hline 2012 & 133 & 2,3 & $236.955 .628,20$ & $43.265 .834,04$ & $280.221 .462,24$ \\
\hline 2013 & 116 & 1,9 & $208.832 .678,00$ & $19.992 .581,34$ & $228.825 .259,34$ \\
\hline 2014 & 17 & 1,0 & $29.988 .115,05$ & $1.588 .919,90$ & $31.577 .034,95$ \\
\hline Total Geral & 498 & 2,0 & $843.039 .016,43$ & $167.733 .503,68$ & $1.010 .772 .520,11$ \\
\hline
\end{tabular}

Fonte: Adaptado de Siconv (2016). 
Tabela L - Prestação de contas sem desembolso - administrações públicas diretas municipais - Período de observação 2008- 2015 - em R $\$$.

\begin{tabular}{|c|c|c|c|c|c|}
\hline \multirow[b]{2}{*}{ Ano } & \multirow[b]{2}{*}{ Quantidade de acordos } & \multirow{2}{*}{$\begin{array}{l}\text { Média de Tempo de } \\
\text { vigência }\end{array}$} & \multicolumn{3}{|c|}{ Valor } \\
\hline & & & Repasse & Contrapartida & Global \\
\hline 2009 & 420 & 2,4 & 220.212.323,24 & $27.607 .463,08$ & $247.819 .786,32$ \\
\hline 2010 & 346 & 2,2 & $201.276 .501,52$ & 21.067.334,59 & $222.343 .836,11$ \\
\hline 2011 & 140 & 2,4 & $77.227 .034,17$ & $6.524 .888,18$ & $83.751 .922,35$ \\
\hline 2012 & 215 & 2,3 & $118.448 .718,85$ & $9.607 .074,64$ & $128.055 .793,49$ \\
\hline 2013 & 726 & 1,9 & $361 \cdot 134.746,43$ & 20.391.266,11 & $381.526 .012,54$ \\
\hline 2014 & 97 & 1,2 & $44.889 .428,16$ & $1.597 .502,75$ & $46.486 .930,91$ \\
\hline Total Geral & 2.004 & 2,1 & 1.033.478.745,93 & $87.965 .622,88$ & 1.121.444.368,81 \\
\hline
\end{tabular}

Fonte: Adaptado de Siconv (2016). 
Tabela M - Prestação de contas sem desembolso - Entidades Privadas sem fins lucrativos - Período de observação 2008- 2015 - em R\$.

\begin{tabular}{|c|c|c|c|c|c|}
\hline \multirow[b]{2}{*}{ Ano } & \multirow[b]{2}{*}{ Quantidade de acordos } & \multirow{2}{*}{$\begin{array}{l}\text { Média de Tempo de } \\
\text { vigência }\end{array}$} & \multicolumn{3}{|c|}{ Valor } \\
\hline & & & Repasse & Contrapartida & Global \\
\hline 2009 & 76 & 1,49 & $117.919 .200,33$ & $5.266 .509,24$ & $123.185 .709,57$ \\
\hline 2010 & 112 & 1,56 & 66.684.191,02 & $10.243 .982,50$ & $76.928 .173,52$ \\
\hline 2011 & 20 & 2,34 & $12.778 .508,87$ & $168.933,56$ & $12.947 .442,43$ \\
\hline 2012 & 17 & 2,07 & $19.896 .823,74$ & $24.362,11$ & $19.921 .185,85$ \\
\hline 2013 & 31 & 1,79 & $16.900 .951,15$ & $5.241,29$ & $16.906 .192,44$ \\
\hline 2014 & 14 & 1,07 & $13.869 .740,80$ & $56.138,40$ & $13.925 .879,20$ \\
\hline Total Geral & 409 & 1,42 & $312.401 .912,66$ & $23.126 .629,76$ & $335.528 .542,42$ \\
\hline
\end{tabular}

Fonte: Adaptado de Siconv (2016). 


\section{APÊNDICE "E" - QUESTIONÁRIO}

\section{Questionário de Levantamento das Percepções dos Gestores Municipais e Distritais em Relação às Transferências Voluntárias na Ótica do Planejamento Orçamentário, Gestão e Controle}

\section{Prezad@!}

Meu nome é Paulo Roberto Magalhães Cordeiro, servidor público do Distrito Federal e mestrando em Economia e Gestão do Setor Público pela Universidade de Brasília.

Estou desenvolvendo uma dissertação sobre a temática: Transferências voluntárias da União, cuja finalidade é levantar algumas percepções sobre o processo de descentralização dos recursos da União para estados, municípios, DF e entidades privadas sem fins lucrativos.

O seu e-mail foi selecionado com base na sua participação no Group: CONVÊNIOS FEDERAIS/SICONV.

Diante disso, solicito sua participação nesta pesquisa que deverá ocupar no máximo 10 (dez) minutos do seu tempo para ser respondida.

Nenhum respondente será identificado na pesquisa, sendo tratado de forma anônima.

Os dados da pesquisa serão a base para a elaboração de dissertação de Mestrado em Economia e Gestão do Setor Público, da Faculdade de Economia, Administração e Contabilidade - FACE, da Universidade de Brasília - UnB.

$\mathrm{O}$ arquivo com as questões encontra-se no anexo. Porém, antes de responder peço que leia as orientações abaixo e responda um breve formulário sobre a qualificação do respondente.

Para auxiliar o entendimento do perfil dos membros que atuam nas áreas de gestão de recursos oriundos de transferências voluntárias da União, mediante convênios ou contratos de repasses, pedimos que respondam algumas informações gerais de qualificação do respondente. 


\begin{tabular}{|c|c|c|}
\hline Estado/Município: & $\begin{array}{l}\text { Órgão de } \\
\text { lotação/Setor: }\end{array}$ & \\
\hline $\begin{array}{l}\text { Nível de } \\
\text { escolaridade: }\end{array}$ & $\begin{array}{l}\text { Se superior, qual } \\
\text { formação: }\end{array}$ & \\
\hline \multirow[t]{3}{*}{$\begin{array}{l}\text { Anos de } \\
\text { experiência no } \\
\text { setor de lotação: }\end{array}$} & $\begin{array}{l}\text { Dedicação do seu } \\
\text { tempo na atividade } \\
\text { de captação e } \\
\text { execução de } \\
\text { recursos públicos: }\end{array}$ & $\begin{array}{l}\text { ( ) } \\
\text { Exclusivamente } \\
\text { dedicado a } \\
\text { atividade }\end{array}$ \\
\hline & & $\begin{array}{l}(\text { ) } \\
\text { Essencialmente } \\
\text { dedicado a } \\
\text { atividade }\end{array}$ \\
\hline & & $\begin{array}{l}\text { ( ) Compartilhado } \\
\text { com outras } \\
\text { atividades }\end{array}$ \\
\hline $\begin{array}{l}\text { Ocupa algum } \\
\text { cargo de chefia? }\end{array}$ & $\begin{array}{l}\text { Se sim, em qual } \\
\text { nível hierárquico? }\end{array}$ & \\
\hline
\end{tabular}

$\mathrm{Na}$ segunda parte da pesquisa, relativo ao questionário presente no anexo a esta mensagem, solicitamos que você marque apenas um numeral na escala que vai de 0 a 10, relacionado a resposta que mais sem aproxima das percepções quanto à gestão dos recursos de transferências voluntárias, em que representa de (0) - Não se aplica/nenhuma/péssimo; (1 a 3) - Aplica-se pouco/baixo/ruim; (4 a 7 ) - Sim, em parte/médio/bom; (8 a 10) - Sim, totalmente/fácil/ótimo.

Após responder, solicito que envie o arquivo e essa ficha de qualificação para o email: paulo.magalhaes10@gmail.com, até a data de 31/05/2016.

De antemão, agradeço!

Paulo Roberto Magalhães Cordeiro.

Celular +55 61 8438-0291 
(0) - Não se aplica/nenhuma/péssimo;

(1 a 3) - Aplica-se pouco/baixo/ruim;

(4 a 7) - Sim, em parte/médio/bom;

(8 a 10) - Sim, totalmente/fácil/ótimo.

\section{PLANEJAMENTO ORÇAMENTÁRIO}

\section{A - ELABORAÇÃO DO PLANO PLURIANUAL - PPA}

a1 Na fase de elaboração do PPA da União, a União disponibiliza canais de comunicação para apresentação de propostas de políticas públicas?

Considerando as demandas de políticas públicas sobre seu órgão, há

a2 iniciativas/incentivos para que técnicos participem da elaboração do PPA da União?

a3

Considerando as proposições perante os setoriais de planejamento da União, há uma boa receptividade quanto ao atendimento das demandas encaminhadas?

Considerando os tramites para a elaboração do PPA, o seu órgão possui colaborados com conhecimentos adequados para participarem na elaboração de propostas no PPA da União?

O distanciamento geográfico em relação a sua instituição para com os órgãos da União dificulta no inter-relacionamento para a proposição de políticas públicas no PPA?

a6 Observa-se o PPA da União e da sua Entidade para a elaboração dos projetos prévios para a captação de recursos?

\begin{tabular}{|c|c|c|c|c|c|c|c|c|c|c|c|}
\hline \multicolumn{10}{|c|}{ ESCALA } \\
\hline 0 & 1 & 2 & 3 & 4 & 5 & 6 & 7 & 8 & 9 & 10 \\
\hline á & 0 & 1 & 2 & 3 & 4 & 5 & 6 & 7 & 8 & 9 & 10 \\
\hline & 0 & 1 & 2 & 3 & 4 & 5 & 6 & 7 & 8 & 9 & 10 \\
\hline & 0 & 1 & 2 & 3 & 4 & 5 & 6 & 7 & 8 & 9 & 10 \\
\hline
\end{tabular}




\section{PLANEJAMENTO ORÇAMENTÁRIO}

B - ELABORAÇÃO DA LEI ORÇAMENTÁRIA ANUAL - LOA

b1 Na fase de elaboração da LOA da União, a União disponibiliza canais de comunicação para apresentação de propostas de políticas públicas?

Considerando as demandas de politicas públicas sobre o seu órgão, há iniciativas/incentivos para técnicos participarem da elaboração da LOA da União?

Considerando as interações perante os setoriais da União, há uma boa

b3 receptividade das propostas de objetos de políticas públicas por parte dos técnicos da União?

Considerando os tramites da elaboração da LOA, o seu órgão possui colaborados

b4 com conhecimentos adequados para participarem da elaboração de propostas na LOA da União?

b5

O distanciamento geográfico da sua instituição para com os órgãos da União dificulta no inter-relacionamento e apresentação das demandas do seu órgão?

Observa-se a LOA da União e da sua Entidade para a elaboração dos projetos prévios para a captação de recursos?

\begin{tabular}{|c|c|c|c|c|c|c|c|c|c|c|c|}
\hline \multicolumn{10}{|c|}{ ESCALA } \\
\hline 0 & 1 & 2 & 3 & 4 & 5 & 6 & 7 & 8 & 9 & 10 \\
\hline & 0 & 1 & 2 & 3 & 4 & 5 & 6 & 7 & 8 & 9 & 10 \\
\hline & 0 & 1 & 2 & 3 & 4 & 5 & 6 & 7 & 8 & 9 & 10 \\
\hline & 0 & 1 & 2 & 3 & 4 & 5 & 6 & 7 & 8 & 9 & 10 \\
\hline
\end{tabular}




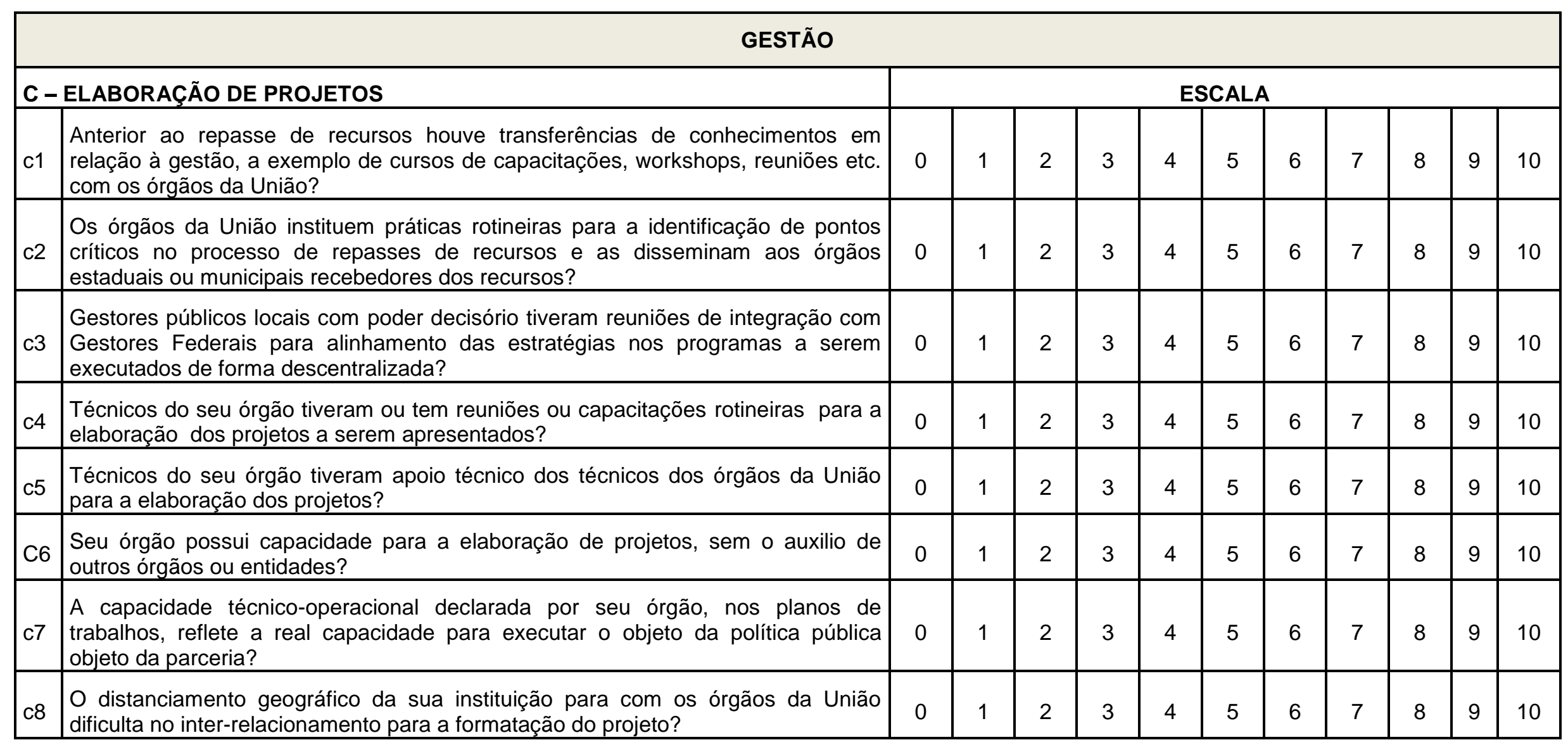




\begin{tabular}{|l|l|l|l|l|l|l|l|l|l|l|l|l|l|}
\hline \multicolumn{7}{|c|}{ GESTÃo } \\
\hline D - EXECUçÃo E ACOMPANHAMENTO & \multicolumn{5}{|c|}{ ESCAL } \\
\hline $\mathrm{d} 1$ & $\begin{array}{l}\text { Há visitas sistemáticas de técnicos da União para verificar o andamento dos } \\
\text { grandes projetos executados por sua entidade? }\end{array}$ & 0 & 1 & 2 & 3 & 4 & 5 & 6 & 7 & 8 & 9 & 10 \\
\hline $\mathrm{d} 2$ & $\begin{array}{l}\text { Há frequentes comunicados dos técnicos da União quanto à observação de } \\
\text { atrasos na execução dos objetos dos acordos? }\end{array}$ & 0 & 1 & 2 & 3 & 4 & 5 & 6 & 7 & 8 & 9 & 10 \\
\hline $\mathrm{d} 3$ & $\begin{array}{l}\text { Há frequentes recomendações quanto à adoção de melhores praticas para a } \\
\text { execução dos acordos? }\end{array}$ & 0 & 1 & 2 & 3 & 4 & 5 & 6 & 7 & 8 & 9 & 10 \\
\hline $\mathrm{d} 4$ & $\begin{array}{l}\text { O distanciamento geográfico da sua instituição para com os órgãos da União } \\
\text { dificulta no inter-relacionamento para o acompanhamento da execução? }\end{array}$ & 0 & 1 & 2 & 3 & 4 & 5 & 6 & 7 & 8 & 9 & 10 \\
\hline $\mathrm{d} 5$ & $\begin{array}{l}\text { O seu órgão possui capacidade técnico-operacional para executar as políticas } \\
\text { públicas pactuadas com a União? }\end{array}$ & 0 & 1 & 2 & 3 & 4 & 5 & 6 & 7 & 8 & 9 & 10 \\
\hline d6 & $\begin{array}{l}\text { A união apoia a realização de eventos para a disseminação das melhores praticas } \\
\text { para a execução dos recursos de transferências voluntárias? }\end{array}$ & 0 & 1 & 2 & 3 & 4 & 5 & 6 & 7 & 8 & 9 & 10 \\
\hline d7 & $\begin{array}{l}\text { De forma geral, como você classifica a gestão da União sobre os recursos } \\
\text { descentralizados para o seu órgão? }\end{array}$ & 0 & 1 & 2 & 3 & 4 & 5 & 6 & 7 & 8 & 9 & 10 \\
\hline
\end{tabular}




\begin{tabular}{|l|l|l|l|l|l|l|l|l|l|l|l|l|}
\hline \multicolumn{7}{|c|}{ CONTROLE } \\
\hline E - CONTROLE & \multicolumn{1}{|c|}{ Escala } \\
\hline e1 & $\begin{array}{l}\text { Existem recomendações do controle interno do estado/município para a melhoria } \\
\text { de gestão dos recursos recebidos por seu órgão? }\end{array}$ & 0 & 1 & 2 & 3 & 4 & 5 & 6 & 7 & 8 & 9 & 10 \\
\hline e2 & $\begin{array}{l}\text { Existem recomendações do controle externo da União para a melhoria da gestão } \\
\text { dos recursos repassados pela a União ao seu órgão? }\end{array}$ & 0 & 1 & 2 & 3 & 4 & 5 & 6 & 7 & 8 & 9 & 10 \\
\hline e3 & $\begin{array}{l}\text { Há considerações do seu órgão sobre as recomendações do controle } \\
\text { interno/externo? }\end{array}$ & 0 & 1 & 2 & 3 & 4 & 5 & 6 & 7 & 8 & 9 & 10 \\
\hline e4 & $\begin{array}{l}\text { As unidades de controle interno acompanham a execução e a prestação de contas } \\
\text { dos recursos recebidos de forma sistemática? }\end{array}$ & 0 & 1 & 2 & 3 & 4 & 5 & 6 & 7 & 8 & 9 & 10 \\
\hline e5 & $\begin{array}{l}\text { É verificada a participação do controle social sobre a atividade de captação e } \\
\text { execução de recursos públicos? }\end{array}$ & 0 & 1 & 2 & 3 & 4 & 5 & 6 & 7 & 8 & 9 & 10 \\
\hline e6 & $\begin{array}{l}\text { As informações sobre a execução físico-financeira estão disponíveis em tempo } \\
\text { real para população focal da política pública? }\end{array}$ & 0 & 1 & 2 & 3 & 4 & 5 & 6 & 7 & 8 & 9 & 10 \\
\hline e7 & $\begin{array}{l}\text { Há mecanismos/sistema para o acompanhamento da execução físico/financeira } \\
\text { pelas partes interessadas, além do sistema Siconv? }\end{array}$ & 0 & 1 & 2 & 3 & 4 & 5 & 6 & 7 & 8 & 9 & 10 \\
\hline
\end{tabular}




\begin{tabular}{|l|l|l|l|l|l|l|l|l|l|l|l|l|l|}
\hline \multicolumn{7}{|c|}{ CONTROLE } \\
\hline $\begin{array}{l}\text { F- ENVOLVIMENTO DA ALTA ADMINISTRAÇÃO (Secretários de } \\
\text { Estado/Municípios, Gestores Federais) }\end{array}$ & \multicolumn{1}{|c|}{ ESCALA } \\
\hline $\mathrm{f} 1$ & $\begin{array}{l}\text { Você considera que a alta administração do seu órgão está envolvida na busca } \\
\text { por melhores práticas para a captação de recursos? }\end{array}$ & 0 & 1 & 2 & 3 & 4 & 5 & 6 & 7 & 8 & 9 & 10 \\
\hline $\mathrm{f} 2$ & $\begin{array}{l}\text { Você considera que a alta administração do seu órgão está envolvida na busca } \\
\text { por melhores práticas para a execução dos recursos recebidos? }\end{array}$ & 0 & 1 & 2 & 3 & 4 & 5 & 6 & 7 & 8 & 9 & 10 \\
\hline $\mathrm{f} 3$ & $\begin{array}{l}\text { Você considera que a alta administração da União está envolvida na busca por } \\
\text { melhores práticas para o repasse dos recursos? }\end{array}$ & 0 & 1 & 2 & 3 & 4 & 5 & 6 & 7 & 8 & 9 & 10 \\
\hline $\mathrm{f} 4$ & $\begin{array}{l}\text { Você considera que a alta administração da União está envolvida na busca por } \\
\text { melhores práticas para a execução dos recursos repassados? }\end{array}$ & 0 & 1 & 2 & 3 & 4 & 5 & 6 & 7 & 8 & 9 & 10 \\
\hline $\mathrm{f} 5$ & $\begin{array}{l}\text { As iniciativas e propostas para melhoria no processo de captação e execução de } \\
\text { recursos são consideradas pela alta administração do seu órgão? }\end{array}$ & 0 & 1 & 2 & 3 & 4 & 5 & 6 & 7 & 8 & 9 & 10 \\
\hline
\end{tabular}




\begin{tabular}{|l|l|l|l|l|l|l|l|l|l|l|l|l|}
\hline \multicolumn{5}{|c|}{ CONTROLE } \\
\hline G - INSTITUIÇÃO DO SISTEMA SICONV & \multicolumn{1}{|c|}{ ESCALA } \\
\hline g1 & $\begin{array}{l}\text { Ocorreu alguma alteração no modo de gerir os recursos com a instituição do } \\
\text { Sistema SICONV? }\end{array}$ & 0 & 1 & 2 & 3 & 4 & 5 & 6 & 7 & 8 & 9 & 10 \\
\hline g2 & $\begin{array}{l}\text { O sistema SICONV permitiu uma melhor integração das informações de execução } \\
\text { dos recursos com os órgãos federais? }\end{array}$ & 0 & 1 & 2 & 3 & 4 & 5 & 6 & 7 & 8 & 9 & 10 \\
\hline g3 & $\begin{array}{l}\text { Com a instituição do Sistema SICONV promoveu uma antecipação na identificação } \\
\text { de programas passiveis de execução por seu órgão? }\end{array}$ & 0 & 1 & 2 & 3 & 4 & 5 & 6 & 7 & 8 & 9 & 10 \\
\hline g4 & $\begin{array}{l}\text { Na instituição do Sistema SICONV, o seu órgão obteve nos últimos três nãos o } \\
\text { apoio dos órgãos da União quanto ao treinamento dos colaboradores para a } \\
\text { utilização? }\end{array}$ & 0 & 1 & 2 & 3 & 4 & 5 & 6 & 7 & 8 & 9 & 10 \\
\hline g5 & $\begin{array}{l}\text { Em referência ao sistema SICONV, você considera que é um sistema que permite } \\
\text { o planejamento? }\end{array}$ & 0 & 1 & 2 & 3 & 4 & 5 & 6 & 7 & 8 & 9 & 10 \\
\hline g6 & Em referência ao sistema SICONV, você o considera como um sistema de gestão? & 0 & 1 & 2 & 3 & 4 & 5 & 6 & 7 & 8 & 9 & 10 \\
\hline g7 & $\begin{array}{l}\text { Em referência ao sistema SICONV, você o considera como um sistema de } \\
\text { controle? }\end{array}$ & 0 & 1 & 2 & 3 & 4 & 5 & 6 & 7 & 8 & 9 & 10 \\
\hline g8 & $\begin{array}{l}\text { Com relação a sua atividade diária na utilização do Sistema SICONV, como você } \\
\text { classificaria o nível de dificuldade na sua operacionalização? }\end{array}$ & 0 & 1 & 2 & 3 & 4 & 5 & 6 & 7 & 8 & 9 & 10 \\
\hline
\end{tabular}




\begin{tabular}{|l|l|l|l|l|l|l|l|l|l|l|l|l|}
\hline \multicolumn{1}{|l|}{ H- AVALIAÇÃO GERAL } & \multicolumn{5}{|c|}{ ESCALA } \\
\hline h1 & $\begin{array}{l}\text { De forma geral, como você classifica a atual sistemática de transferências } \\
\text { voluntárias da União? }\end{array}$ & 0 & 1 & 2 & 3 & 4 & 5 & 6 & 7 & 8 & 9 & 10 \\
\hline h2 & $\begin{array}{l}\text { De forma geral, como você classifica a o desempenho do seu órgão na gestão dos } \\
\text { recursos de transferências voluntárias? }\end{array}$ & 0 & 1 & 2 & 3 & 4 & 5 & 6 & 7 & 8 & 9 & 10 \\
\hline h3 & $\begin{array}{l}\text { De forma geral, você classifica o processo de repasses de recursos voltado para o } \\
\text { planejamento? }\end{array}$ & 0 & 1 & 2 & 3 & 4 & 5 & 6 & 7 & 8 & 9 & 10 \\
\hline h4 & $\begin{array}{l}\text { De forma geral, você classifica o processo de repasses de recursos voltado para a } \\
\text { Gestão? }\end{array}$ & 0 & 1 & 2 & 3 & 4 & 5 & 6 & 7 & 8 & 9 & 10 \\
\hline h5 & $\begin{array}{l}\text { De forma geral, você classifica o processo de repasses de recursos voltado para o } \\
\text { Controle? }\end{array}$ & 0 & 1 & 2 & 3 & 4 & 5 & 6 & 7 & 8 & 9 & 10 \\
\hline
\end{tabular}

